RENATA RUGGIER DE MATTOS

EFEITOS DA MORFINA EM FASES DISTINTAS

DA GESTAÇÃO DE RATAS:

COMPORTAMENTO MATERNAL, DESENVOLVIMENTO FÍSICO E

NEUROCOMPORTAMENTAL DAS PROLES E BIOLOGIA MOLECULAR DOS RECEPTORES OPIÓIDES

Dissertação apresentada ao Programa de PósGraduação em Farmacologia do Instituto de Ciências Biomédicas da Universidade de São Paulo, para obtenção do Título de Mestre em Ciências. 


\section{EFEITOS DA MORFINA EM FASES DISTINTAS DA GESTAÇÃO DE RATAS: COMPORTAMENTO MATERNAL, DESENVOLVIMENTO FÍSICO E NEUROCOMPORTAMENTAL DAS PROLES E BIOLOGIA MOLECULAR DOS RECEPTORES OPIÓIDES}

Dissertação apresentada ao Programa de PósGraduação em Farmacologia do Instituto de Ciências Biomédicas da Universidade de São Paulo, para obtenção do Título de Mestre em Ciências.

Área de concentração: Farmacologia

Orientadora: $\operatorname{Prof}^{\mathrm{a}} \mathrm{Dr}^{\mathrm{a}}$ Elizabeth Teodorov

Co-orientador: Prof. Dr. Luciano F. Felício

Versão corrigida. A versão original eletrônica encontra-se disponível tanto na biblioteca do ICB quanto na biblioteca digital de teses e dissertações da USP (bdtd) 
DADOS DE CATALOGAÇÃO NA PUBLICACÃO (CIP)

Serviço de Biblioteca e Informação Biomédica do

Instituto de Ciências Biomédicas da Universidade de São Paulo

(c) reprodução total

Mattos, Renata Ruggier de

Efeitos da morfina em fases distintas da gestação de ratas:

comportamento maternal, desenvolvimento físico e

neurocomportamental das proles e biologia molecular dos receptor /

Renata Ruggier de Mattos. -- São Paulo 2014

Orientador: Profa. Dra. Elizabeth Teodorov.

Dissertação (Mestrado) - Universidade de São Paulo. Instituto de Ciências Biomédicas. Departamento de Farmacologia. Área de concentração: Farmacologia. Linha de pesquisa:

Neuropsicofarmacologia.

Versão do título para o inglês: Effects of morphine at different stages of pregnancy in rats: maternal behavior, physical and neurobehavioral development of the offspring and molecular biology of opioid receptors

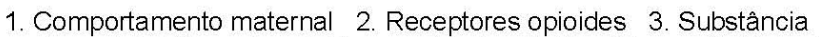
periaquedutal Cinzenta 4. Corpo estriado 5. Hipotálamo 6. Biologia molecular I. Teodorov, Profa. Dra. Elizabeth II. Universidade de São Paulo. Instituto de Ciências Biomédicas. Programa de Pós-Graduação em Farmacologia III. Título. 
UNIVERSIDADE DE SÃO PAULO

INSTITUTO DE CIÊNCIAS BIOMÉDICAS

\section{Candidato(a): $\quad$ Renata Ruggier de Mattos.}

Título da Dissertação: $\quad$ Efeitos da morfina em fases distintas da gestação de ratas: comportamento maternal, desenvolvimento físico e neurocomportamental das proles e biologia molecular dos receptor.

Orientador(a): $\quad$ Profa. Dra. Elizabeth Teodorov.

A Comissão Julgadora dos trabalhos de Defesa da Dissertação de Mestrado, em sessão pública realizada a .................., considerou

( ) Aprovado(a) ( ) Reprovado(a)

Examinador(a): Assinatura:

Nome:

Instituição:

Examinador(a): Assinatura:

Nome:

Instituição:

Presidente: Assinatura:

Nome:

Instituição: 
UNIVERSIDADE DE SÃO PAULO

INSTITUTO DE CIÊNCIAS BIOMÉDICAS

Cidade Universitária "Armando de Salles Oliveira"

Av. Prof. Lineu Prestes, 2415 - CEP. 05508-000 São Paulo, SP Brasil

Telefone :(55) (011) 3091.7733 - e-mail: cep@icb.usp.br

\section{Certificado}

Certificamos que o protocolo registrado sob n ${ }^{\circ} \mathbf{1 8 3}$ nas fls. $\mathbf{1 1 4}$ do livro $\mathbf{0 2}$ para uso de animais em experimentação, sob a responsabilidade do Prof(a) Dr(a)) Luciano de Freitas Felicio, Coordenador (a) da Linha de pesquisa "Efeitos da morfina em ratas gestantes: desenvolvimento físico e neurocomportamental das proles, comportamento maternal e biologia molecular de receptores opioides" do qual participam o(s) aluno(s) Renata Ruggier de Mattos e a pesquisadora Elizabeth Teodorov, está de acordo com os Princípios Éticos de Experimentação Animal adotado pela Sociedade Brasileira de Ciência de Animais de Laboratório (SBCAL) e foi aprovado pela COMISSÃO DE ÉTICA NO USO DE ANIMAIS (CEUA) em 08.05.2012, com validade de 4 anos.

São Paulo, 09 de maio de 2012.

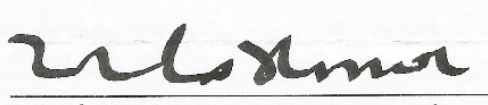

Prof. Dr. Wothan TAVARES DE LIMA Coordenador CEUA - ICB/USP

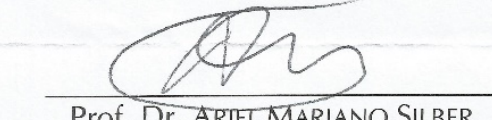

Prof. Dr. ARIEL MARIANO SILBER Secretário CEUA - ICB/USP 
UNIVERSIDADE DE SÃO PAULO

\section{Comissão de Ética no uso de animais}

\section{CERTIFICADO}

Certificamos que o Projeto intitulado "Efeitos da morfina em ratas gestantes: desenvolvimento físico e neurocomportamental das proles, comportamento maternal e biologia molecular de receptores opióides", protocolado sob o $\mathrm{n}^{\circ}$ 2540/2012, utilizando 80 (oitenta) ratos, sob a responsabilidade do Prof. Dr, Luciano Freitas Felício, está de acordo com os princípios éticos de experimentação animal da "Comissão de Ética no uso de animais" da Faculdade de Medicina Veterinária e Zootecnia da Universidade de São Paulo e foi aprovado em reunião de $15 / 2 / 2012$.

We certify that the Research "Effects of morphine treatment in pregnant female rats: physical and neurobehavioral development, maternal behavior and molecular biology of opioid receptors", protocol number 2540/2012, utilizing 80 (eighty) rats, under the responsibility Prof. Dr. Luciano Freitas Felício, agree with Ethical Principles in Animal Research adopted by "Ethic Committee in the use of animals" of the School of Veterinary Medicine and Animal Science of University of São Paulo and was approved in the meeting of day 2/15/2012.

São Paulo, 13 de março de 2012.

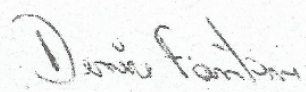

Denise Tabacchi Fantoni

Presidente 


\section{AGRADECIMENTOS}

A Deus, por despertar em mim a paixão por todas as escolhas que fiz ao longo da vida, e por me conceder a cada dia a oportunidade de escolher denovo.

A minha pequena e amorosa família que sempre respeitou minhas escolhas, e que sempre esteve ao meu lado em todos os momentos me apoiando e me amando incondicionalmente. Que sempre souberam demonstrar toda admiração e respeito pelo meu caminhar fazendo disso meu maior estímulo para continuar mesmo diante de todas as dificuldades. Meu amados Theresa, Marcio, Dany, Victória e Giovanna dedico a vocês todo o esforço para a subida de mais esse degrau.

A meu marido, companheiro, amigo fiel, patrocinador e meu maior incentivador Tiago, nunca encontrarei palavras capazes de demonstrar todo meu amor e minha gratidão por tudo o que você é e faz por mim. Todos os dias felizes, difíceis e tristes era você que estava lá para comemorar, enfrentar e chorar ao meu lado. A cada momento de indecisão era você que estava lá para iluminar meu caminho. A cada dia em que o trabalho tomou de mim todo o tempo que eu tinha, você estava lá para me receber com um abraço e um sorriso. Certas coisas nunca poderão ser ditas mas podem sim serem sentidas, e eu sei que você sente todo o amor e gratidão que lhe dedico todos os dias em que acordamos e passamos juntos. Essa escalada tem muito de você, a quem também dedico com todo meu amor.

A todos meus amigos pessoais que mesmo sem entender nada do que eu estava fazendo, sempre tiveram muito orgulho do lugar onde cheguei e até onde posso ir.

A minha orientadora e amiga $\operatorname{Prof}^{\mathrm{a}} \mathrm{Dr}^{\mathrm{a}}$ Elizabeth Teodorov que em tantas ocasiões foi muito além e fez por mim muito mais do que uma orientadora faria, que sempre compreendeu e respeitou minhas necessidades, limitações e anseios se colocando sempre como um ponto de apoio. Com seu método de ministrar aulas fez nascer em mim a paixão pela farmacologia e pela docência, com sua humanidade e com seu caráter consegue se manter em meio a tantas dificuldades e alguns sofrimentos, com isso fazendo que eu acredite que é possível conquistar alguns sonhos. A sua generosidade e o respeito que teve por mim ao longo de toda essa estrada como profissional e ser humano, fizeram de você um exemplo que eu pretendo seguir, de preferência ao seu lado nas estradas que ainda virão pela frente. 
Ao Prof. Luciano F. Felício que abriu as portas de seu laboratório e me acolheu com muito respeito e carinho e toda sua equipe que sempre esteve ao meu lado me ajudando em meio aos experimentos, suportando todas as crises de nervosismo e choro (que não foram poucos), ou simplesmente me fazendo companhia e divertindo as longas horas de trabalho, a vocês queridos Marianne, Magali, Carla, Renato.

Aos colegas de profissão Jullie, Luana, Lucas, Wesley que tanto me ensinaram e ajudaram, a Regina que sempre esteve a minha disposição para me ajudar com o que fosse necessário, a todas as pessoas do biotério e do Departamento de Patologia da Faculdade de Medicina Veterinária e Zootecnia da Universidade de São Paulo por toda a ajuda e respeito.

A Prof ${ }^{a} \operatorname{Dr}^{\mathrm{a}}$ Maria Martha Bernardi por toda a paciência e sabedoria.

A Prof ${ }^{a} \operatorname{Dr}^{\mathrm{a}}$ Rosana Camarini e toda equipe do laboratório de Neuroquímica e Farmacologia Comportamental por ceder seu espaço para a execução de alguns de meus experimentos e em especial ao André Rueda que com uma generosidade ímpar, dedicou muito de seu tempo me ensinando e acompanhando em experimentos.

A Coordenação de Aperfeiçoamento de Nível Superior (CAPES), pela concessão de bolsa de auxílio financeiro.

A todos que direta ou indiretamente contribuíram e estiveram ao meu lado nessa etapa da minha vida, o meu muito obrigada! 
“O êxito da vida não se mede pelo caminho que você conquistou, mas sim pelas dificuldades que superou no caminho." 


\section{RESUMO}

MATTOS, R. R. Efeitos da morfina em fases distintas da gestação de ratas: comportamento maternal, desenvolvimento físico e neurocomportamental das proles e biologia molecular dos receptores opióides. 2014. 187 f. Dissertação (Mestrado em Farmacologia) - Instituto de Ciências Biomédicas, Universidade de São Paulo, São Paulo, 2014.

Opióides são substâncias de origem endógena ou sintética, referindo-se a todos os compostos relacionados ao ópio. O protótipo dos agonistas opióides, a morfina, é conhecida há muito tempo pela sua capacidade de aliviar a dor intensa com notável eficácia. Assim como os peptídeos opióides endógenos, a morfina exerce seus efeitos farmacológicos por meio de ligação com três tipos de receptores endógenos conhecidos como $\mu, \kappa$ e $\delta$. Estudos demostram que a ativação opioidérgica endógena pode influenciar aspectos reprodutivos em ratos como por exemplo e cuidado maternal. Este é um comportamento complexo, espontâneo, instintivo e com características espécie-específicas determinadas por modificações fisiológicas que ocorrem pouco antes ou logo após o parto e deve ajustar-se à uma série de variáveis como disponibilidade de alimentos, temperatura ambiente e proximidade de predadores. São esses cuidados que determinam a manutenção das espécies pois garantem um adequado desenvolvimento físico, neurológico e comportamental das proles. Muitas regiões encefálicas são apontadas como sítios moduladores do CM. Estudos com expressão da proteína cFos que investigou esse cenário mostrou a importância da substância cinzenta periaquedutal (PAG) no comportamento maternal (CM). Outras estruturas como por exemplo, o corpo estriado é uma região encefálica envolvida do controle motor que por sua vez é determinante na execução do $\mathrm{CM}$, assim como o eixo hipotalâmico-hipofisário-gonadal que está intimamente relacionado com a modulação hormonal responsável pelo surgimento de alguns comportamentos como o maternal. Trabalhos mostraram que os estados fisiológico e reprodutivo, por si só, são capazes de alterar também a biologia molecular do sistema opioidérgico nesse cenário. Quando ratas foram tratadas com cloridrato de morfina do $17^{\circ}$ ao $21^{\circ}$ dias de gestação (terço final) houve alteração na expressão dos genes que codificam para os receptores opióides em regiões implicadas com o controle do CM e alteraram os produtos protéicos. Sendo assim, o objetivo deste trabalho foi avaliar os efeitos da administração de sulfato de morfina no primeiro e segundo terços da gestação de ratas no $\mathrm{CM}$, em parâmetros físico e neurocomportamental das proles e na biologia molecular de receptores opióides em diferentes regiões encefálicas nas mães e nas proles. Para isso foram utilizadas 80 ratas (Rattus norvegicus) da linhagem Wistar, com aproximadamente 90 dias de idade e peso corporal entre 180 e 250 g no início dos experimentos. Foram estabelecidos dois protocolos para a administração de morfina/salina de acordo com o estágio da gestação; Protocolo 1: tratamento com a dose de morfina/salina do $2^{\circ}$ ao $6^{\circ}$ dias de gestação e Protocolo 2: tratamento com a dose de morfina/salina do $11^{\circ}$ ao $15^{\circ}$ dias de gestação. Os resultados mostraram que tratamento com morfina no primeiro e segundo terços da gestação de ratas alterou alguns parâmetros do CM como a recuperação dos filhotes, e alterou alguns parâmetros do desenvolvimento físico como o ganho de peso e o desenvolvimento dos órgãos sexuais e desenvolvimento neurocomportamental em ambas as proles, bem como os padrões de expressão gênica e produtos protéicos nas mães e em suas proles no estriado, hipotálamo e PAG. Conclui-se, portanto que o tratamento com morfina durante a gestação de ratas pode alterar o estado fisiológico das mães com implicações diretas nas proles.

Palavras-chave: Comportamento maternal. Receptores opióides. Substância cinzenta periaquedutal. Corpo estriado. Hipotálamo. Biologia molecular. 


\begin{abstract}
MATTOS, R. R. Effects of morphine at different stages of pregnancy in rats: maternal behavior, physical and neurobehavioral development of the offspring and molecular biology of opioid receptors. 2014. 187 p. Masters thesis (Pharmacology) - Instituto de Ciências Biomédicas, Universidade de São Paulo, São Paulo, 2014.
\end{abstract}

Opioids are substances of endogenous or synthetic origin, referring to all related to the opium compounds. The prototype opioid agonists, morphine, is long known for its ability to relieve severe pain with remarkable effectiveness. Like the endogenous opioid peptides, morphine exerts its pharmacological effects by binding to three kinds of endogenous receptors known as $\mu, \delta$ and $\kappa$. Studies show that endogenous activation opioidergic can influence reproductive function in rats for example and maternal care. This is a complex, spontaneous, instinctive and species-specific behavioral characteristics determined by physiological changes that occur shortly before or after delivery and must adjust to a number of variables such as food availability, temperature and proximity of predators. Care are these which determine the species because they ensure an adequate physical, neurological and behavioral development of the offspring. Many brain regions are identified as modulators of the CM sites. Studies on expression of cFos protein that investigated this scenario showed the importance of the periaqueductal gray (PAG) in maternal behavior (CM). Other structures such as the striatum is a brain region involved in motor control which in turn is determinant in the performance of $\mathrm{CM}$, and the hypothalamic-pituitary-gonadal axis is closely related to modulation hormone responsible for the appearance of some behaviors such as maternal. Studies have shown that the physiological and reproductive states, by themselves, are also able to alter the molecular biology of the opioid system in this scenario. When rats were treated with morphine hydrochloride from $17^{\text {th }}$ to $21^{\text {th }}$ days of pregnancy (final third) was no change in expression of genes encoding opioid receptors in regions implicated in the control of CM and altered the protein product. Thus, the aim of this study was to evaluate the effects of the administration of morphine sulfate in the first two thirds of pregnancy of rats in CM, in physical and neurobehavioral parameters of the offspring and molecular biology of opioid receptors in different brain regions in the mother and progenies. For this 80 rats (Rattus norvegicus) of the Wistar strain, approximately 90 days old and weighing between 180 and $250 \mathrm{~g}$ at the beginning of the experiments were used. Two protocols were established for the administration of morphine / saline according to the stage of pregnancy; Protocol 1: treatment with the dose of morphine / saline 2nd to 6th days of pregnancy and Protocol 2: treatment with a dose of morphine / saline the 11th to 15th days of gestation. The results showed that morphine treatment in the first two thirds of pregnancy of rats changed some parameters of the $\mathrm{CM}$ as the recovery of the puppies, and changed some of the physical parameters such as weight gain and the development of sex organs and neurobehavioral development in both offspring as well as the patterns of gene expression and protein products in mothers and their offspring in the striatum, hypothalamus and PAG. It follows therefore that treatment with morphine during pregnancy in rats can alter the physiological status of mothers with direct implications in offspring.

Keywords: Maternal behavior. Physical development in rats. Opioids. Periaqueductal gray. Striatum. Hypothalamus. 


\section{LISTA DE FIGURAS}

Figura 1 - Estrutura química da morfina.

Figura 2 - Modelo proposto para a topografia da membrana do receptor opióide $\mu$ em ratos.

Figura 3 - Representação esquemática da sinalização intracelular decorrente da ativação do receptor opióide.

Figura 4 - Representação esquemática dos parâmetros avaliados durante o comportamento maternal em roedores.

Figura 5 - Representação esquemática e anatômica da localização da PAG.

Figura 6 - Localização esquemática do corpo estriado.................................................. 27

Figura 7 - Representação esquemática do eixo hipotálamo - hipófise - gônadas............. 29

Figura 8 - Lâmina de lavado vaginal contendo espermatozoides (x 400) ....................... 34

Figura 9 - Representação esquemática do delineamento experimental do tratamento no $1^{\circ}$ terço da gestação.

Figura 10 - Representação esquemática do delineamento experimental do tratamento no $1^{\circ}$ terço da gestação.

Figura 11 - Aparato experimental utilizado para realização e filmagem dos testes comportamentais nas mães.

Figura 12 - Recuperação de cada filhote ao início da avaliação do CM ........................ 37

Figura 13 - Agrupamento de todos os filhotes no ninho .............................................. 38

Figura 14 - Cifose fisiológica ou "Crouching" refere-se ao posicionamento da rata sobre os filhotes agrupados a fim de facilitar a amamentação............... 38

Figura 15 - Comportamento Maternal Total............................................................ 39

Figura 16 - Rato aos 10 dias de vida......................................................................... 40

Figura 17 - Plataforma com inclinação de $45^{\circ}$ para observação da geotaxia negativa.

Figura 18 - Equipamento MyECL Imager ${ }^{\circledR}$.

Figura 19 - Avaliação do parâmetro de recuperação de cada filhote referente do comportamento maternal de ratas tratadas ou não com sulfato de morfina no primeiro ou segundo terços da gestação.

Figura 20 - Avaliação dos parâmetros de agrupamento dos filhotes, crounching e CMT referente ao comportamento maternal de ratas tratadas ou não com sulfato de morfina no primeiro ou segundo terços da gestação.

Figura 21 - Avaliação do ganho de peso das ninhadas femininas de ratas tratadas ou não com sulfato de morfina no primeiro ou segundo terços da gestação.

Figura 22 - Média do ganho de peso total das ninhadas femininas de ratas tratadas ou não com sulfato de morfina no primeiro ou segundo terços da gestação.

Figura 23 - Avaliação do ganho de peso das ninhadas masculinas de ratas tratadas ou não com sulfato de morfina no primeiro ou segundo terços da gestação.

Figura 24 - Avaliação do ganho de peso total das ninhadas masculinas de ratas tratadas ou não com sulfato de morfina no primeiro ou segundo terços da gestação. 
Figura 25 - Avaliação do desenvolvimento físico das ninhadas femininas de ratas tratadas ou não com sulfato de morfina no primeiro ou segundo terços da gestação

Figura 26 - Avaliação do desenvolvimento físico das ninhadas masculinas de ratas tratadas ou não com sulfato de morfina no primeiro ou segundo terços da gestação.

Figura 27 - Avaliação dos parâmetros do reflexo de geotaxia negativa, endireitamento da postura e resposta de preensão palmar relacionados ao desenvolvimento físico das ninhadas femininas de ratas tratadas ou não com sulfato de morfina no primeiro ou segundo terços da gestação

Figura 28 - Avaliação dos parâmetros do reflexo de geotaxia negativa, endireitamento da postura e resposta de preensão palmar relacionados ao desenvolvimento físico das ninhadas masculinas de ratas tratadas ou não com sulfato de morfina no primeiro ou segundo terços da gestação.

Figura 29 - Análise da expressão de Oprk1, Oprm1 e Oprd1, bem como dos produtos protéicos KOR, MOR e DOR no estriado de ratas tratadas ou não com sulfato de morfina no primeiro e segundo terços da gestação

Figura 30 - Análise da expressão de Oprk1, Oprm1 e Oprd1, bem como dos produtos protéicos KOR, MOR e DOR no hipotálamo de ratas tratadas ou não com sulfato de morfina no primeiro e segundo terços da gestação.

Figura 31 - Análise da expressão de Oprk1, Oprm1 e Oprd1, bem como dos produtos protéicos KOR, MOR e DOR na PAG de ratas tratadas ou não com sulfato de morfina no primeiro e segundo terços da gestação...........

Figura 32 - Análise da expressão de Oprk1, Oprm1 e Oprd1, bem como dos produtos protéicos KOR, MOR e DOR no estriado das proles femininas de ratas tratadas ou não com sulfato de morfina no primeiro e segundo terços da gestação.

Figura 33 - Análise da expressão de Oprk1, Oprm1 e Oprd1, bem como dos produtos protéicos KOR, MOR e DOR no hipotálamo das proles femininas de ratas tratadas ou não com sulfato de morfina no primeiro e segundo terços da gestação.

Figura 34 - Análise da expressão de Oprk1, Oprm1 e Oprd1, bem como dos produtos protéicos KOR, MOR e DOR na PAG das proles femininas de ratas tratadas ou não com sulfato de morfina no primeiro e segundo terços da gestação.

Figura 35 - Análise da expressão de Oprk1, Oprm1 e Oprd1, bem como dos produtos protéicos KOR, MOR e DOR no estriado das proles masculinas de ratas tratadas ou não com sulfato de morfina no primeiro e segundo terços da gestação.

Figura 36 - Análise da expressão de Oprk1, Oprm1 e Oprd1, bem como dos produtos protéicos KOR, MOR e DOR no hipotálamo das proles masculinas de ratas tratadas ou não com sulfato de morfina no primeiro e segundo terços da gestação.

Figura 37 - Análise da expressão de Oprk1, Oprm1 e Oprd1, bem como dos produtos protéicos KOR, MOR e DOR na PAG das proles masculinas de ratas tratadas ou não com sulfato de morfina no primeiro e segundo terços da gestação. 


\section{LISTA DE TABELAS}

Tabela 1 - Classificação de ninho observado ao $5^{\circ}$ dia de lactação, em ratas tratadas ou não com sulfato de morfina no primeiro terço da gestação.

Tabela 2 - Classificação de ninho observado ao $5^{\circ}$ dia de lactação, em ratas tratadas ou não com sulfato de morfina no primeiro terço da gestação. 


\section{SUMÁRIO}

1 INTRODUÇÃO E REVISÃO DA LITERATURA........................................ 17

1.1 Sobre o sistema opioidérgico...................................................................... 17

1.2 Sobre o comportamento maternal em roedores........................................... 21

1.3 Sobre as regiões encefálicas envolvidas no comportamento maternal......... 24

1.4 Aspectos moleculares do sistema opioidérgico, relação com o comportamento maternal e áreas encefálicas envolvidas............................ 29

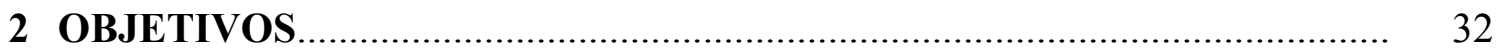

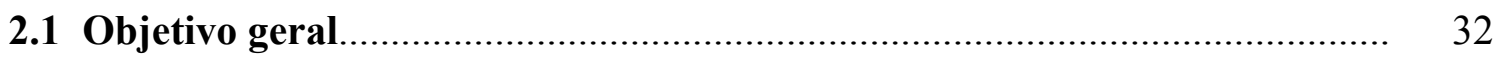

2.2 Objetivos específicos............................................................................... 32

3 MATERIAIS E MÉTODOS.................................................................... 33

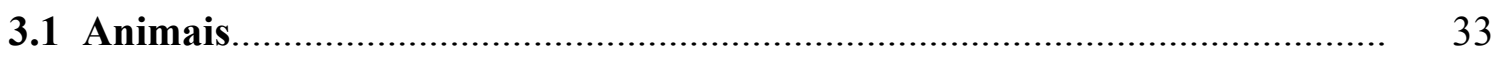

3.2 Acasalamento e padronização das ninhadas.............................................. 33

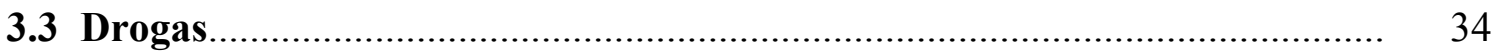

3.4 Delineamento experimental geral................................................................ 34

3.5 Habituação e manipulação dos animais....................................................... 36

3.6 Avaliação do comportamento maternal........................................................ 37

3.7 Avaliação do desenvolvimento físico das proles............................................ 39

3.8 Avaliação do desenvolvimento neurocomportamental das proles................ 41

3.9 Análise da expressão dos genes Oprk1, Oprm1 e Oprd1 dos receptores opióides $\kappa, \mu$ e $\delta$ respectivamente, $n$ estriado, hipotálamo e PAG de ratas suas respectivas proles

3.9.1 Extração de RNA total (método de TRIZOL) ................................................. $\quad 42$

3.9.2 Ensaio de transcrição reversa $(R T$ PCR) ...................................................... $\quad 42$

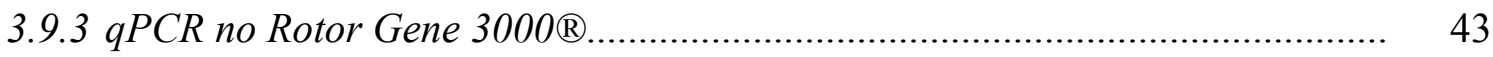

3.10 Análise dos produtos protéicos KOR, MOR e DOR dos receptores opióides $\mu, \kappa$ e $\delta$ respectivamente, na PAG, estriado e hipotálamo de ratas suas respectivas proles.

3.10.1 Preparo das amostras................................................................................ 44

3.10.2 Quantificação de proteínas......................................................................... 44

3.10.3 Eletroforese em gel de poliacrilamida sob condições denaturantes.............. $\quad 44$

3.10.4 Eletro-transferência das proteínas ............................................................... 45

3.10.5 Imunodeteç̧ão das proteínas de interesse ................................................... $\quad 45$

3.10.6 Leitura e normalização das proteinas de interesse pelo equipamento

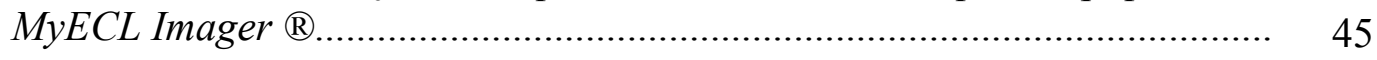

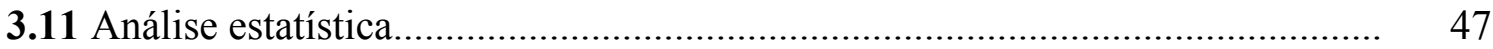

4 RESULTADOS ................................................................................... 49

4.1 Experimento 1 - Avaliação do tratamento com sulfato de morfina ou não em diferentes períodos da gestação de ratas no comportamento maternal.

4.1.1 Delineamento experimental........................................................................ 48

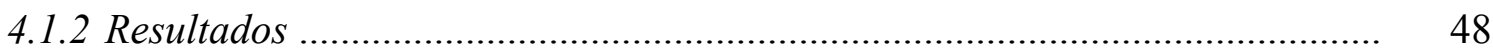


4.2 Experimento 2 - Avaliação do peso corporal das proles de ratas tratadas ou não com sulfato de morfina no primeiro ou segundo terços da gestação

4.2.1 Delineamento experimental................................................................. 58

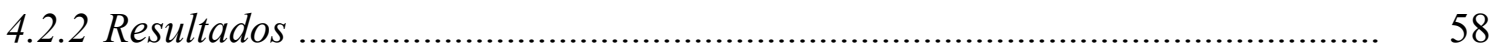

4.3 Experimento 3 - Avaliação do desenvolvimento físico das proles feminina e masculina de ratas tratadas ou não com sulfato de morfina no primeiro ou segundo terços da gestação.

4.3.1 Delineamento experimental......................................................................... 67

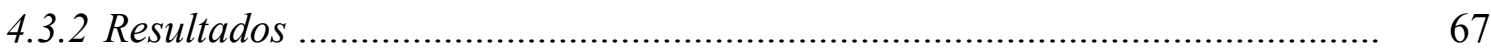

4.4 Experimento 4 - Avaliação do desenvolvimento neurocomportamental das proles feminina e masculina de ratas tratadas ou não com sulfato de morfina no primeiro ou segundo terços da gestação

4.4.1 Delineamento experimental......................................................................... 75

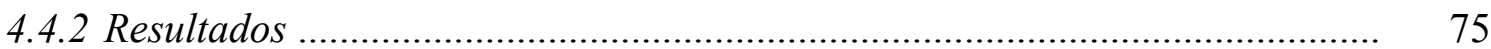

4.5 Experimento 5 - Análise da expressão de Oprk1, Oprm1 e Oprd1 que codificam para os receptores opióides $\kappa, \mu$ e $\delta$ respectivamente, bem como os produtos protéicos KOR, MOR e DOR no estriado, hipotálamo e PAG de ratas bem como das proles femininas e masculinas

4.5.1 Delineamento experimental.

4.5.2 Resultado1 - qPCR de receptores opióides e produtos protéicos nas mães.....

4.5.3 Resultado 2 - qPCR de receptores opióides e produtos protéicos nas proles femininas.

4.5.4 Resultado 3 - qPCR de receptores opióides e produtos protéicos nas proles masculinas. 


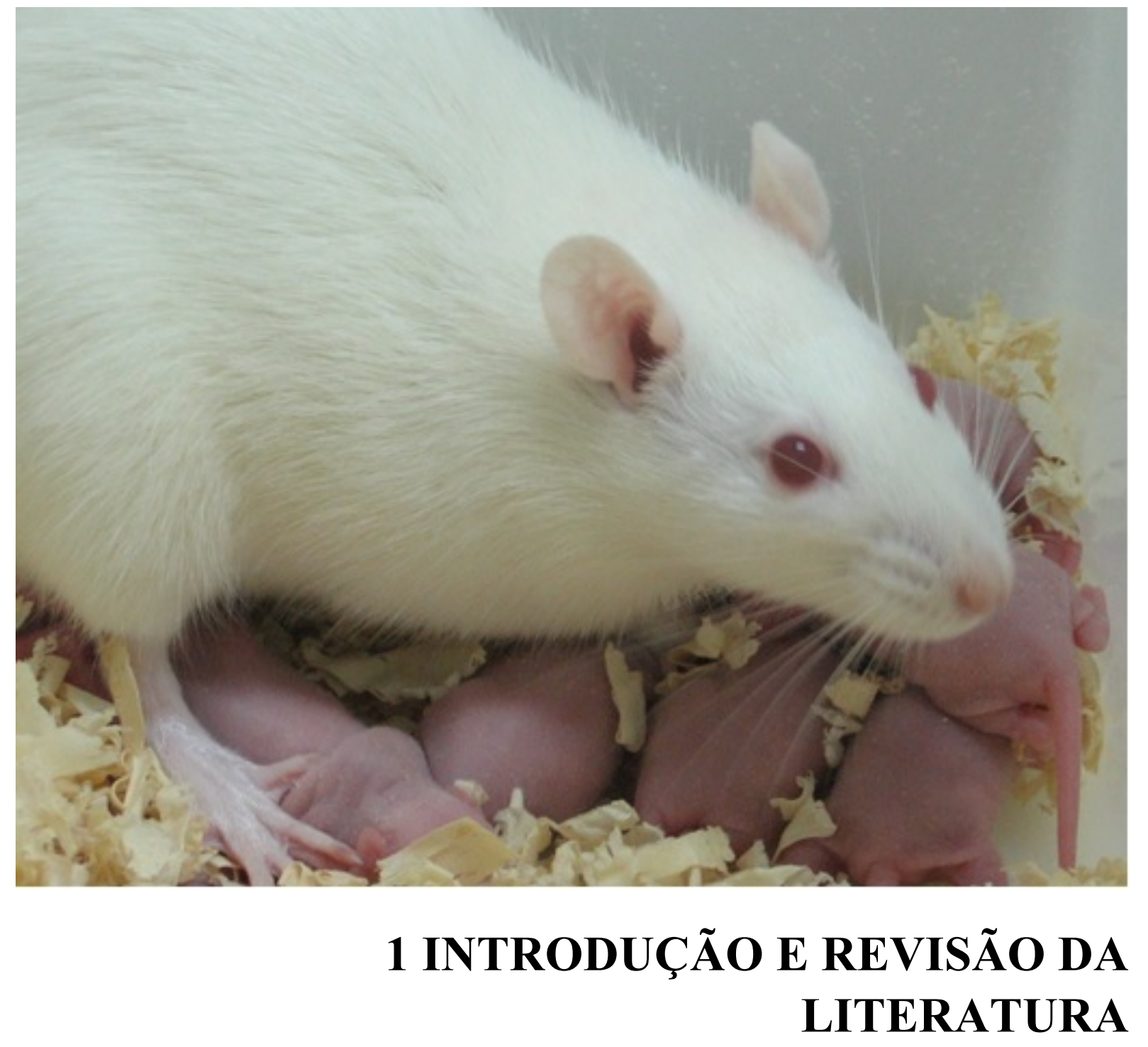




\subsection{Sobre o sistema opioidérgico}

Opióides são substâncias de origem endógena ou sintética, referindo-se a todos os compostos relacionados ao ópio. O termo opium deriva da palavra grega opus, que significa suco, pois o fármaco é retirado do suco da papoula (Papaver somniferum) (GUTSTEIN; AKIL, 2005). O protótipo dos agonistas opióides, a morfina, é conhecido há muito tempo pela sua capacidade de aliviar a dor intensa com notável eficácia sendo um dos derivados do ópio que foi isolada pela primeira vez por Sertürner em 1806, e tem seu nome derivado de Morfeu, Deus grego dos sonhos.

A morfina continua sendo o padrão a partir do qual todas as drogas com acentuada ação analgésica são comparadas, sendo conhecidas como “analgésicos opióides". Estas incluem não somente os derivados alcalóides naturais e semi-sintéticos do ópio, como também substitutos sintéticos, outros agentes semelhantes aos opióides cujas ações são bloqueadas pelo antagonista não-seletivo naloxona e vários peptídeos endógenos. A estrutura química da morfina encontra-se representada na Figura 1.

Figura 1 - Estrutura química da morfina.

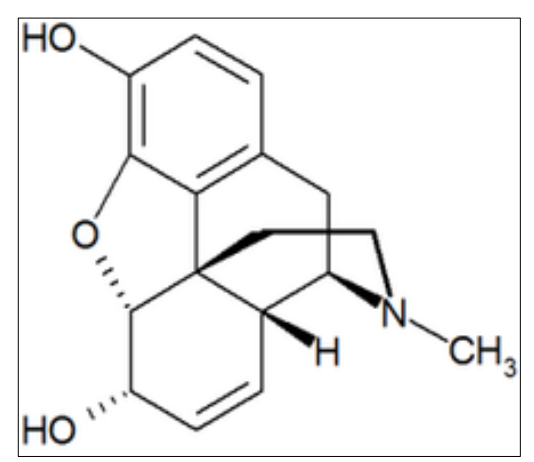

As duplas ligações entre as moléculas de carbono encontram-se representadas em negrito. Retirado de Teodorov (2008).

Assim como os peptídeos opióides endógenos, a morfina exerce seus efeitos farmacológicos por meio de ligação com receptores endógenos, sendo que os trabalhos de Gilbert e Martin (1976) e Martin et al. (1976) foram os primeiros a relatar evidências farmacológicas definitivas que sustentaram a existência de receptores opióides endógenos. Os sítios de ligação dos receptores opióides foram localizados por técnicas auto-radiográficas, utilizando a ligação de radioligantes de alta afinidade com anticorpos dirigidos contra seqüências peptídicas específicas em cada receptor. 
Gilbert e Martin (1976) relataram a existência de três tipos de receptores opióides com base nas ações farmacológicas observadas por estudos em cães. Assim, estes receptores foram denominados $\mu$ (mi) para o tipo morfina e $\kappa$ (kappa) para ketociclozacina. Posteriormente, Lord et al. (1977) encontraram um receptor com alta afinidade para encefalinas em camundongos, o qual foi denominado $\delta$ (delta). Evidências farmacológicas indicam que o receptor opióide $\delta$ é expresso no corno dorsal da medula espinal e áreas límbicas, o que atribui a este tipo de receptor ações como analgesia, depressão respiratória, comportamentos afetivo e de reforço e redução da motilidade gastrointestinal. Assim, observa-se que as respostas dos receptores $\mu$ e $\delta$ são muito semelhantes.

A ativação de receptores opióides por ligantes endógenos e exógenos resulta em múltiplos efeitos como analgesia, depressão respiratória, euforia, liberação de hormônios, inibição do trato gastrointestinal e efeitos na ansiedade (WALDHOER; BARTLETT; WHISTLER, 2004). Acredita-se que os receptores $\mu$ sejam responsáveis pela maioria dos efeitos analgésicos dos opióides e por alguns dos efeitos adversos importantes como, por exemplo, sedação, euforia e dependência. A morfina, mesmo sendo um agonista opióide não seletivo, parece ter seus efeitos farmacológicos mais importantes mediados por este tipo de receptor (RANG et al., 2007).

Os receptores opióides são do tipo metabotrópicos e pertencem à grande superfamília de receptores acoplados à proteína G (GPCRs), como mostra Figura 2. Como classe, os GPCRs são de importância fisiológica fundamental pois afetam a regulação de canais iônicos, modulam o processamento de $\mathrm{Ca}^{2+}$ e alteram a fosforilação de proteínas.

Figura 2 - Modelo proposto para a topografia da membrana do receptor opióide $\mu$ em ratos.

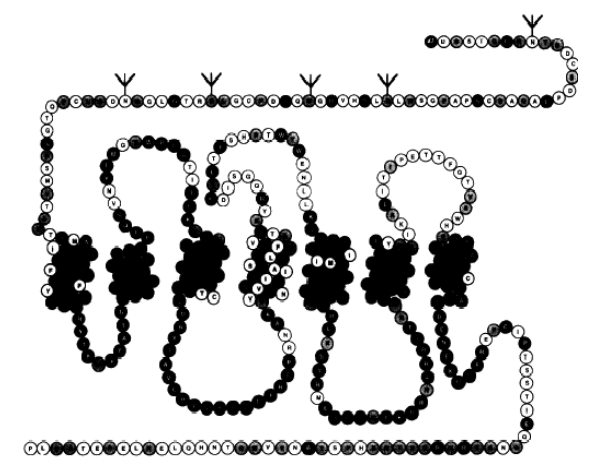

Os resíduos de aminoácidos do receptor opióide $\mu$ são conservados em ambos receptores opióides $\kappa$ e $\delta$ (círculos pretos), ou ainda, não se expressam nesses receptores (círculos brancos). Adaptado de Pasternak e Standifer (1995). Retirado de Teodorov (2008). 
A estrutura do receptor GPCR que contém um proteína com porções extracelulares (que se ligam a seus agonistas) e subunidades intracelulares que são as responsáveis pelo tipo de resposta que a ativação deste receptor desencadeará (Figura 3). Essas subunidades são classificadas de acordo com a sua isoforma (estrutura e sequência de aminoácidos), sendo que as principais isoformas são a Gs, Gq e Gi (RANG et al., 2007). Em linhas gerais, a proteína G é composta de três subunidades $(\alpha, \beta$ e $\gamma)$, sendo a subunidade $\alpha$ ligada ao nucleotídeo GDP (difosfato de guanosina). Alterações conformacionais no receptor geradas pela ligação do agonista, promovem a troca do GDP para o GTP (trifosfato de guanosina) na subunidade $\mathrm{G}_{a}$, levando a dissociação do trímero as subunidades $G_{\alpha}$ e $G_{p r}$. Nessas condições, ambas as subunidades podem associar-se com vários efetores (canais iônicos ou enzimas) para modular suas funções biológicas (TEODOROV, 2008). No caso dos receptores opióides, a subunidade Gai inibe a enzima adenilil-ciclase que, por sua vez, reduz a produção do AMPc (monofosfato de adenosina cíclico). Neste sentido, a redução da produção do AMPc diminui a liberação de neurotransmissores, por reduzir a atividade da via AMPc - PKA (proteína quinase A), conforme esquematizado na Figura 3. Sendo assim, os opióides reduzem a excitabilidade celular ao promover hiperpolarização da membrana pela ativação da condutância do potássio e inibição dos canais de cálcio (dependentes de voltagem). Ambos mecanismos sendo mediados pela subunidade $\mathrm{G}_{\beta \gamma}$ da proteína G (EGUCHI, 2004). 
Figura 3 - Representação esquemática da sinalização intracelular decorrente da ativação do receptor opióide.

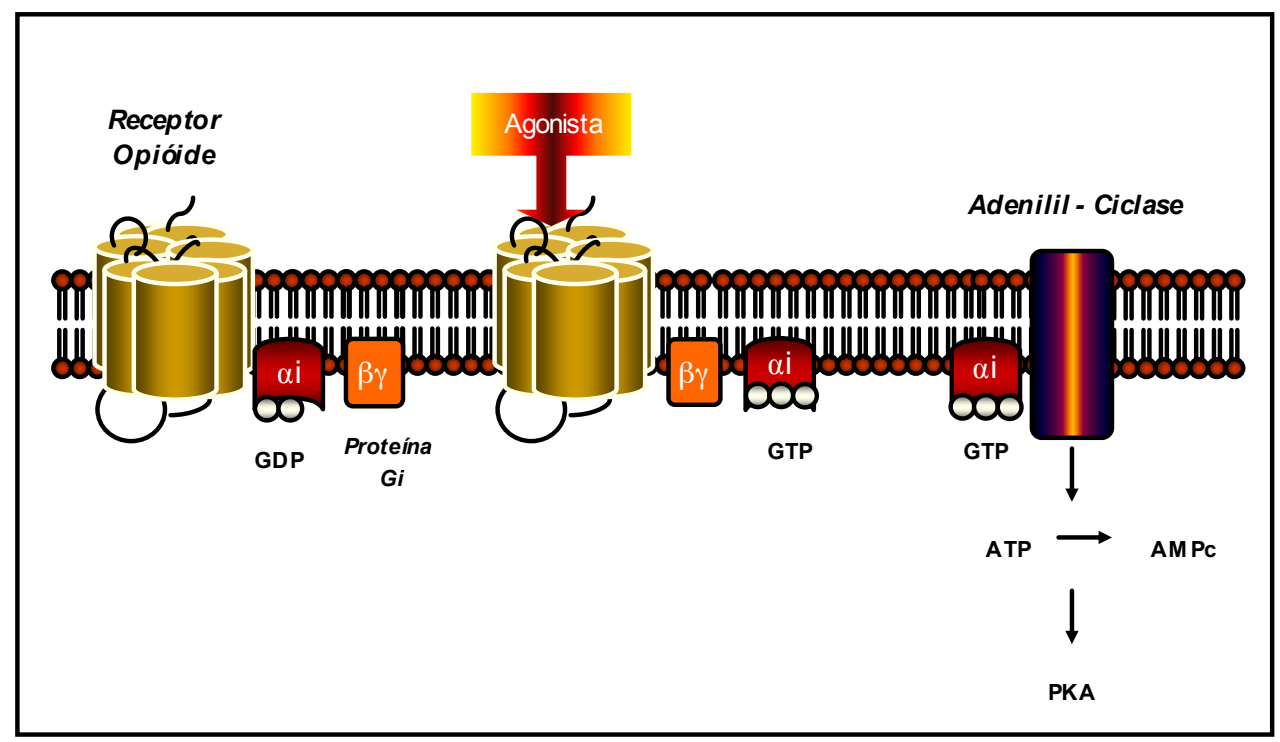

Alterações conformacionais no receptor decorrente da ligação do agonista, promove a troca do GDP pelo GTP ligado a subunidade $\alpha i$ da proteína G. Com a troca dos nucleotídeos, o trímero da proteína $\mathrm{G}$ se dissocia nas

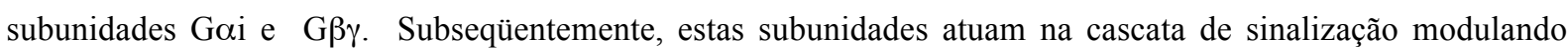

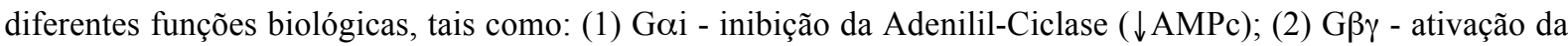
condutância ao potássio e inibição dos canais de cálcio dependentes de voltagem; (3) AMPc - inibição da liberação de neurotransmissores ( $\downarrow$ AMPc - PKA). Adaptado de Katzung (2006). Retirado de Teodorov. (2008).

Assim, agonistas opióides quando utilizados cronicamente, podem induzir tolerância ou sensibilização (tolerância reversa), fenômenos estes em que os efeitos iniciais do fármaco são alterados ao longo do tratamento (KORNETSKY, 2004; MOLLEREAU et al., 1994; WHISTLER et al., 1999). Drogas de abuso psicoativas, especialmente morfina e cocaína, têm efeitos acentuados sobre áreas importantes do encéfalo e as alterações decorrentes à dependência parecem ser permanentes (DE VRIES et al., 1996). De fato, administrações repetidas de opióides ou psicoestimulantes, produzem um aumento progressivo e durável na atividade locomotora de animais, resultante da liberação cálcio-dependente de dopamina, no núcleo accumbens e no corpo estriado (BABBINI; DAVIS, 1972; BARTOLETTI et al., 1983; CADONI; DI CHIARA, 1999; KURIBARA, 1996). Entretanto, estudos realizados por Vanderschuren et al. (2001) mostraram que ratos expostos por uma única vez à morfina (10 ou $30 \mathrm{mg} / \mathrm{kg}$ ), apresentaram sensibilização comportamental permanente, associada a mecanismos neuroadaptativos. 


\subsection{Sobre o comportamento maternal em roedores}

O comportamento exibido pela maioria das aves e mamíferos de cuidar de um outro organismo neonato e imaturo da mesma espécie vem sendo objeto de extensas investigações nas últimas décadas a fim de elucidar os mecanismos envolvidos neste comportamento. Em mamíferos, o conjunto de cuidados que a mãe oferece aos filhotes é denominado comportamento maternal (CM). O cuidado maternal é um comportamento complexo, espontâneo, instintivo e com características espécie-específicas determinadas por modificações fisiológicas que ocorrem pouco antes ou logo após o parto (NUMAN, 1994; MATTSON et al., 2001). Entre outras modificações que ocorrem com a mãe, há a redução de medo, aumento do aprendizado e de memória, o que favorece que ela possa deixar o ninho em busca de alimento estando preparada para adversidades que possa encontrar no caminho e que possibilita um retorno mais breve aos cuidados com a prole (KINSLEY et al., 1999; ZIMBERKNOPF et al., 2011).

O CM deve ajustar-se à uma série de variáveis como disponibilidade de alimentos, temperatura ambiente e proximidade de predadores. A avaliação do $\mathrm{CM}$ em roedores compreende alguns parâmetros conhecidos como busca, recuperação, agrupamento, grooming dos filhotes e crounching (postura de amamentação), como mostra a Figura 4.

Figura 4 - Representação esquemática dos parâmetros avaliados durante o comportamento maternal em roedores.
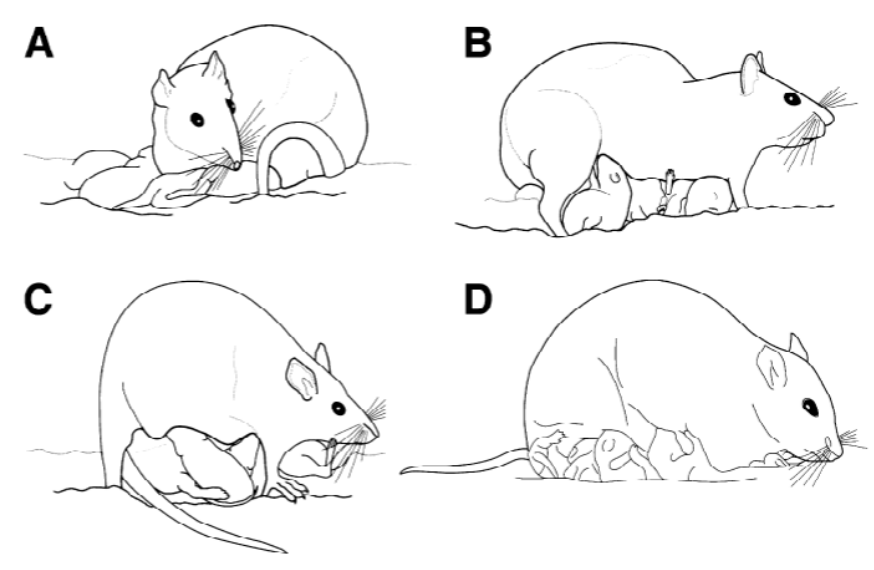

Parâmetros de CM em roedores. Agrupamento (A), início da posição de amamentação (B), "crouching” ou cifose fisiológica (C) e comportamento maternal total (D). Retirado de Teodorov (2008). 
Diversos fatores ambientais, endócrinos, neurais e psicológicos podem interagir na indução do CM. A mudança que ocorre durante a prenhes, do encéfalo de um animal virgem para um encéfalo materno, é complexa, e é determinada pela interação entre hormônios gestacionais e determinados genes que podem ser super ou pouco expressos (KINSLEY; AMORY-MEYER, 2011). Além disso, o encéfalo das mães também é moldado por suas experiências, o que de alguma maneira envolve a regulação epigenética dos comportamentos e sistemas neurais (CURLEY; MASHOODH; CHAMPAGNE, 2011; HAO et al., 2011; JOHNSON et al., 2011; KINSLEY; AMORY-MEYER, 2011).

As bases neurobiológicas do CM foram investigadas inicialmente por Wiesner e Sheard (1993) que sugeriram por meio de estudos sobre o papel crítico desempenhado pela prolactina, que alterações internas decorrentes do final da gestação poderiam ser responsáveis pelo aparecimento do CM. Rosenblatt (1967) avaliou comparativamente a ocorrência de CM em ratas gestantes e não gestantes e concluiu que mudanças hormonais e eventos físiológicos associados com o final da gestação são essenciais para estimular o início do CM concomitantemente ao nascimento dos filhotes. Variações nos níveis séricos de estrógeno, progesterona, prolactina, ocitocina, vasopressina, colecistocinina e $\beta$-endorfina são importantes para que a fêmea cuide de seus filhotes adequadamente logo após o nascimento (NUMAN, 1994; SANYAL, 1978; SHAIKH, 1971; THORBURN; CHALLIS, 1979).

Numan (1994) mostrou que a flutuação hormonal ao final da gestação, onde a queda brusca de progesterona plasmática e aumento dos níveis séricos de estrógenos e prolactina é determinante para que ocorra o CM logo após ao nascimento dos filhotes. Moltz et al. (1970) demonstraram a indução do CM em ratas ovariectomizadas, após tratamento com estrógeno, seguido de aplicações de progesterona e prolactina. Em 48 horas de exposição aos filhotes as fêmeas submetidas ao tratamento hormonal completo expressam CM, enquanto fêmeas que receberam apenas dois destes hormônios não apresentaram o CM com a mesma intensidade, indicando que aquele padrão de alteração do perfil hormonal, com queda nas concentrações de progesterona e aumento nas de estrógeno e prolactina no final da gestação, é fundamental para a expressão otimizada do CM.

Acredita-se que todos estes hormônios interajam com diversos sítios neurais críticos para a expressão do CM, tais como a área pré-óptica medial (APOM) e a porção ventral do núcleo intersticial da estria terminal (BRIDGES et al., 1990). Por exemplo, o implante de estrógeno na APOM reduz as latências para o $\mathrm{CM}$, podendo interferir no aumento da motivação para o comportamento e facilitando o controle motor associado ao mesmo (NUMAN, 1974). Estímulos sensoriais provenientes dos filhotes e captados pela rata, tais 
como vocalizações ultrassônicas e odores, também podem eliciar respostas maternais (LEON; ADEL; COOPERSMITH, 1985). Ainda, manipulações farmacológicas são muito utilizadas em estudos das vias neurais, bioquímicas e moleculares e componentes que estão envolvidos e que promovem o CM adequado, garantindo assim a sobrevivência dos filhotes e a perpetuação da espécie.

O desenvolvimento físico, neurológico e comportamental das proles de determinadas espécies dependem, em grande parte, dos cuidados prestados por suas mães por um determinado período da vida pós natal e são esses cuidados que determinam a manutenção dessas espécies pois garantem que os filhotes se desenvolvam de forma adequada e que possam, quando adultos, se reproduzir e assim perpetuarem suas espécies (RONCA; LAMKIM; ALBERTS, 1993). Além disto, em algumas condições alguns animais são vulneráveis a alterações químicas ou ambientais, o que pode acarretar em defeitos congênitos como anormalidades morfológicas, bioquímicas ou funcionais.

Algumas vezes, esses defeitos só são detectados durante a vida neonatal ou na adolescência, sendo que algumas manifestações só são perceptíveis na idade adulta, como desenvolvimento morfológico anormal ou mudanças comportamentais ou de aprendizagem, muitas vezes de difícil correlação com eventos ocorridos no período gestacional (HARBISON, 1975). Alterações químicas e/ou ambientais ocorridas em períodos determinados do desenvolvimento embrionário, são determinantes para o aparecimento de algumas anomalias no neonato, adolescente ou até mesmo no individuo adulto de algumas espécies. Segundo Houillon (1972), os períodos de desenvolvimento embriológico e fetal consistem em um desenrolar contínuo de mudanças e variações complexas, durante os quais se desenvolvem processos similares nas diferentes espécies de vertebrados, incluindo o homem.

De acordo com Teodorov et al. (2006), o período embriogênico é o mais sensível para ocorrências de anormalidades morfológicas e estruturais. Já nos períodos fetal e neonatal onde os animais crescem e alguns sistemas sofrem maturação. Devido a isso, alterações tardias no comportamento animal podem ser notadas em consequência de alterações ocorridas no período de desenvolvimento fetal. Trabalhos mostram que o estresse neonatal, associados a alguns tratamentos farmacológicos influenciam a expressão de genes e podem impactar no desenvolvimento e no aprendizado (HAYS et al., 2012). Em estudos realizados onde ratas gestantes e lactantes recebem doses de agonistas opioidérigicos no final da gestação, Felício, Mann e Bridges (1991) e Miranda-Paiva (1999), mostraram comprometimento dos parâmetros de desenvolvimento físico e neurocomportamental das proles, porém não se sabe se essas 
alterações são devidas ao tratamento farmacológico das mães no final da prenhes (ou seja, ação direta das drogas no encéfalo dos filhotes) ou se seria devido às alterações do ambiente materno e que implicariam em déficits diretos nas proles. Por outro lado, caso esses parâmetros sejam alterados, não são conhecidos se perduram pela vida do animal, ou se os fenômenos de plasticidade sináptica seriam suficientes para reverter esse quadro.

\subsection{Sobre as regiões encefálicas envolvidas no comportamento maternal}

Segundo Klein (2012) estudos recentes de neuroimagem têm indicado que muitas das regiões que contribuem para o $\mathrm{CM}$ em ratas são ativadas durante a ocorrência de comportamento materno em mães humanas (NUMAN; FLEMING; LEVY, 2006). Ao comparar o volume de regiões encefálicas de mulheres nas primeiras semanas após o parto e 3 a 4 meses após o mesmo, Kim et al. (2010), encontraram aumento de volume principalmente no córtex pré-frontal, nos lobos parietais e áreas mesencefálicas, como o hipotálamo, substância nigra e amígdala, que são áreas relacionadas a motivação e CM, (KLEIN, 2012). Estudos preliminares, no início da década de 1970 sobre as bases neurais do CM, revelaram que lesões, implantes hormonais ou alterações químicas produzidas em áreas especificas do encéfalo podem fornecer informações sobre as funções neurais envolvidas com o $\mathrm{CM}$ (ANDERSEN; TUFIK, 2010). A APOM é considerada como essencial para a expressão do CM. Estudos mostram que lesões no bulbo olfatório e amígdala facilitaram o CM em ratas virgens, entretanto esse fenômeno só é observado se a APOM estiver intacta (NUMAN, 1994).

Numan (1994), mostrou que implantes de estrógeno na APOM reduzem as latências para o CM, podendo interferir no aumento da motivação para o comportamento e facilitando o controle motor associado ao mesmo. Outra importante região é a área tegmental ventral (ATV), a qual possui diversas projeções ascendentes e descendentes de acordo com Beckstead, Domesick e Nauta (1979); Fallon e Moore (1978), Simon, Moal e Calas (1979), sendo que algumas projeções ascendentes alcançam o estriado, particularmente a porção ventral. Segundo Teodorov et al. (2008a), as estruturas estriatais fazem parte do sistema motor extrapiramidal, que têm influência sobre os mecanismos corticais e prosencefálicos da função motora, as projeções APOM-ATV ganham acesso ao sistema motor e promovem processos relacionados ao CM via projeções ATV-estriado (CONRAD; PFAFF, 1976; HABER et al., 1985; SWANSON et al., 1984; YOUNG; ALHEID; HEIMER, 1984). Estudos com expressão da proteína cFos têm investigado a importância da substância cinzenta 
periaquedutal (PAG) no CM (MIRANDA-PAIVA et al., 2003a, b). Esta região está envolvida com muitas funções como vocalização (HOLSTEGE, 1989), respostas ao medo (FANSELOW, 1991) e receptividade sexual (HENNESSEY et al., 1990). Segundo Lonstein e Stern (1997) a PAG está diretamente relacionada com comportamentos reprodutivos e de defesa, bem como em induzir a posição de cifose fisiológica em ratas lactantes e ainda, a agressividade materna.

A PAG é a região do mesencéfalo que circunda o aqueduto cerebral (Figura 5) e é uma importante região do sistema nervoso central (SNC) que está envolvida em vários mecanismos comportamentais e fisiológicos: medo, ansiedade, antinocicepção, controle cardiovascular, vocalização, luta ou fuga, comportamento aversivo, comportamento de caça predatória, comportamento de acasalamento e receptividade sexual e lordose sexual de acordo com Behbehani (1995), Lovivk e Devall (2009) e Mota-Ortiz et al. (2009), bem como em induzir a posição de cifose fisiológica (permanência da fêmea sobre a ninhada na postura apropriada à amamentação) e agressividade materna em ratas lactantes.

Figura 5 - Representação esquemática e anatômica da localização da PAG

(A)

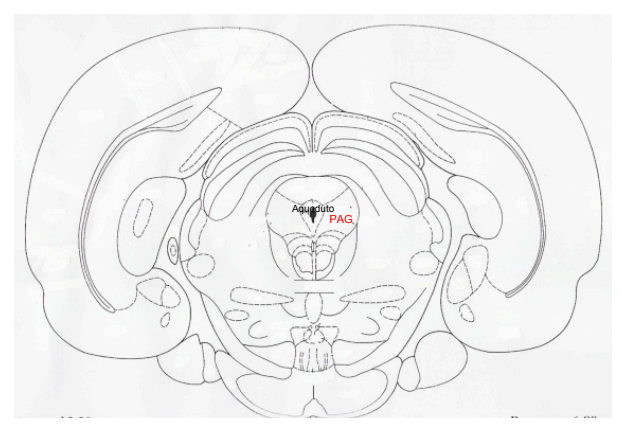

(B)

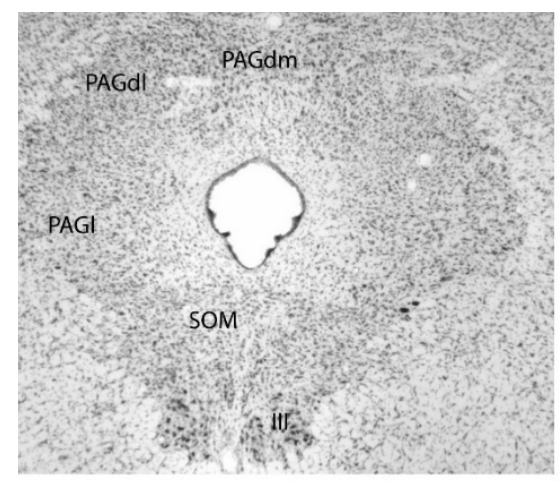

Localização da PAG em corte de encéfalo (A), retirado de Paxinos; Watson (1996). Anatomia da PAG (B), evidenciando sua localização junto ao terceiro ventrículo, além de suas subsdivisões, sendo PAG dorso-ventral 
(PAGdm), PAG dorso-lateral (PAGdl), PAG lateral (PAGl) e núcleo supra oculomotor (SOM) Retirado de Teodorov (2008).

Lonstein e Stern (1997) e Stern (1996) mostraram que a expressão do CM mobiliza as regiões lateral e ventrolateral da parte caudal da PAG que estariam envolvidas particularmente na organização da cifose fisiológica. A ativação opioidérgica da PAG lateral (PAGl) foi capaz de inibir o $\mathrm{CM}$ em ratas lactantes permitindo a expressão de outros comportamentos como os envolvidos com predação e forrageamento (COMOLI; RIBEIROBARBOSA; CANTERAS, 2003). Trabalho conduzido por Miranda-Paiva (2003) mostrou que o efeito inibitório causado pela morfina sobre o comportamento maternal foi interrompido pela injeção unilateral de naloxona na PAGl mas não em regiões do núcleo reticular mesencefálico. Segundo Teodorov (2008), o estudo realizado por Comoli; Ribeiro-barbosa; Canteras, (2003), demonstrou que o mesmo setor da PAG mobilizado durante a inibição opioidérgica do CM, também se apresenta igualmente mobilizado em animais que estavam procurando alimento ou água (forrageamento). Este resultado é consistente com o trabalho realizado por Miranda-Paiva et al. (2003a), no qual foi confirmado em experimentos que o efeito inibitório da morfina sobre a resposta maternal foi bloqueado por uma injeção unilateral de naloxona na PAG lateral rostral. Diante disso escolheu-se a PAG para o presente estudo, que junto a outras regiões como o corpo estriado e o hipotálamo que também estão intimamente relacionadas com o comportamento maternal.

No contexto da modulação comportamental, os gânglios da base representam uma importante conexão subcortical entre o córtex motor e o restante do córtex encefálico. Atuam, portanto, na interface entre o planejamento, programação e ação motora com as demais funções corticais (BRANDÃO, 2004). Eles são constituídos por grandes estruturas, bem delimitadas, entre as quais se destacam o núcleo caudado, o putamen e o globo pálido. Como o núcleo caudado e o putamen desenvolveram-se a partir de uma mesma estrutura telencefálica, eles apresentam tipos celulares semelhantes e são fundidos anteriormente, a região encefálica que compreende tais sub-regiões é conhecida como corpo estriado (Figura 6) e é regulado em parte por inputs dopaminérgicos da substância nigra. 
Figura 6 - Localização esquemática do corpo estriado.

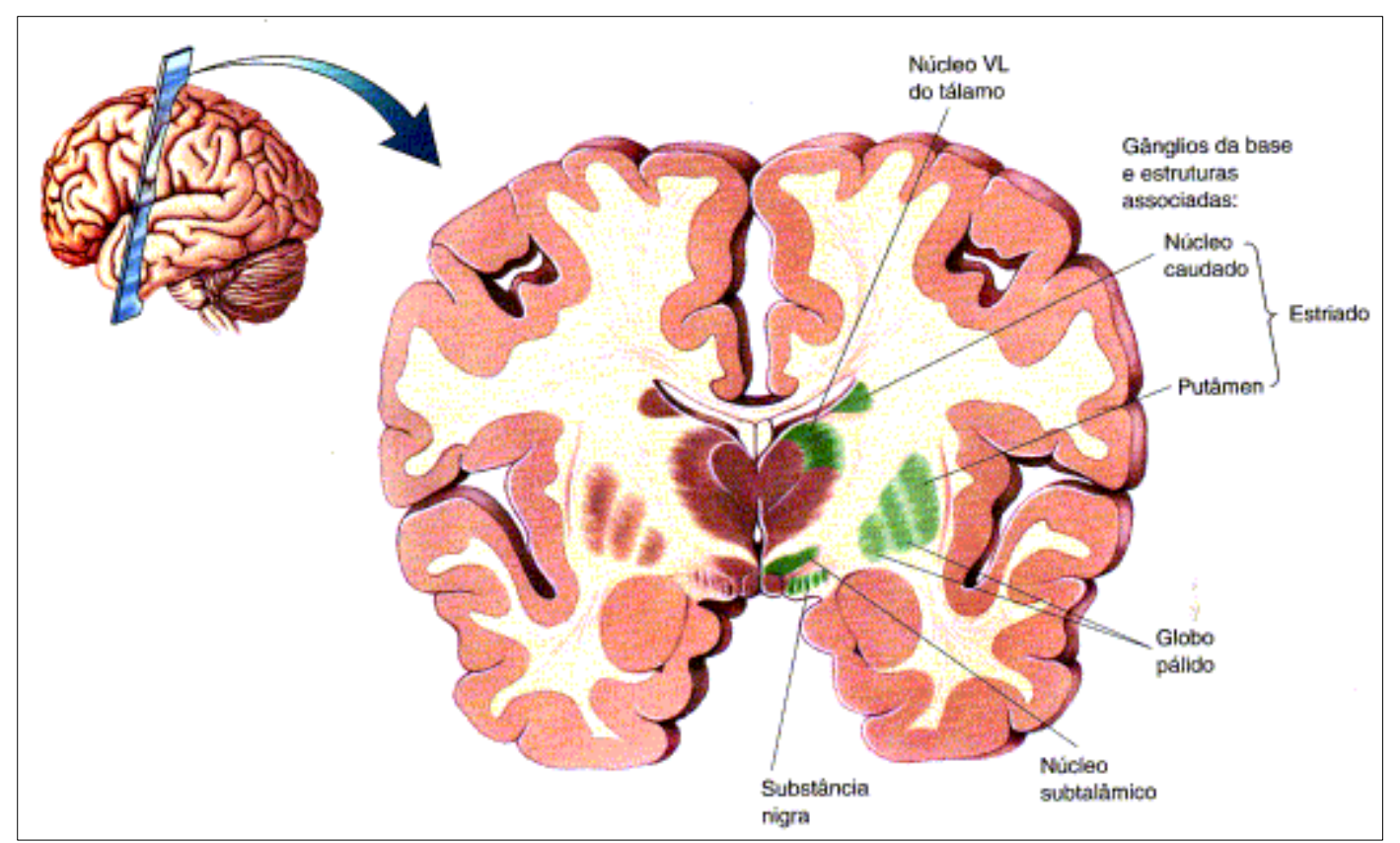

Fonte: afh.bio.br, autorizado por Ana Luisa Miranda Vilela (2013).

Segundo Brandão (2004) as fibras pálido - talâmicas destacam-se dentre as eferências do corpo estriado, pois terminam nos núcleos ventral - anterior e ventrolateral do tálamo, os quais conectam-se ao córtex. Neurônios motores corticais projetam-se na medula ventral e também no estriado regulando a função motora. Os gânglios da base estão ativamente implicados no processo de transformação do planejamento de movimentos elaborados no córtex associativo em programas de movimentos, isto é, na integração e organização tempoespacial dos comandos motores em sua via para ativar os centros motores no tronco cerebral.

O corpo estriado é composto por $96 \%$ dos neurônios gabaérgicos que são conhecidos por conter receptores dopaminérgicos (DA), que dividem-se em dois ramos principais: receptor D1 (D1R) expressando via direta e o receptor D2 (D2R) expressando via indireta Jung et al. (2011) estas vias trabalham em conjunto em relação a modulação comportamental. Segundo Haghparast et al. (2013) receptores dopaminérgicos do tipo D1 tem um papel importante na interação funcional entre a ATV e o hipocampo. A ativação da ATV aumenta os níveis de dopamina e sua liberação no hipocampo parece ter um papel crucial na plasticidade hipocampal. O comportamento sexual, principalmente o de acasalamento em roedores machos segue um padrão específico de sua espécie governado por uma complexa interação de diferentes sistemas no processamento de informações sensoriais do encéfalo, regulando recompensa e motivação, e integrando sinais hormonais (HULL et. al., 1999). Os receptores ativados por hormônios sexuais (receptores andrógenos - AR) são basicamente 
localizados nas áreas límbicas tais como o hipotálamo, essas áreas participam do controle do funcionamento do sistema endócrino e na expressão de comportamento sexual na APOM (FERNANDÉZ-GUASTI; ROLDÁN-ROLDÁN; SALDÍVAR, 2000). O núcleo ventromedial do hipotálamo (VMN) tem sido implicado numa ampla variedade de funções, tais como a alimentação e comportamentos defensivos, regulação das respostas autonômicas e produção hormonal pela hipófise anterior, mecanismos antinociceptivos e controlo somatomotor (CANTERAS; SIMERLY; SWANSON, 1994). No entanto, o VMN é particularmente conhecido pelo importante papel que desempenha no controle do reflexo da lordose em relação ao comportamento sexual feminino, (PFAFF; SAKUMA, 1979a, b). Em ratas, este comportamento ocorre tipicamente em fase de proestro onde elas se encontram sexualmente receptivas como uma resposta a secreção sequencial de estrogênio progesterona pelos ovários.

Sendo assim o hipotálamo aparece como uma estrutura crítica na integração dos comportamentos sexual, reprodutivo e maternal, sendo que a principal relação entre essa região e estes comportamentos tanto em machos quanto em fêmeas ocorre devido a ação dos hormônios sexuais que atuam no eixo hipotálamo-hipófise-adrenal. É a região que mais possui aferências para a PAG, que também recebe inputs do tronco cerebral, do prosencéfalo basal e de regiões corticais. Os sistemas límbico, motor e autonômico possuem aferências para a região, sendo possível, portanto, que a PAG represente uma área de integração desses três sistemas (BEITZ, 1982). A área pré-óptica medial do hipotálamo apresenta ainda algumas características estruturais dimórficas que têm servido como evidências morfológicas no SNC para a diferenciação do comportamento sexual entre machos e fêmeas.

Segundo Brandão (2004) os comportamentos reprodutivo, sexual e maternal é regulado primariamente através de hormônios lançados na circulação sanguínea pelas glândulas sexuais e pela hipófise anterior (hormônios gonadotróficos hipofisários). A sua secreção é fortemente influenciada pelos hormônios gonadais (estrogênio e progesterona nos ovários, e testosterona nos testículos) e pelos hormônios reguladores de origem hipotalâmica, também conhecidos como fatores liberadores ou inibidores de hormônios secretados na adenoipófise (Figura 7). 
Figura 7 - Representação esquemática do eixo hipotálamo - hipófise - gônadas

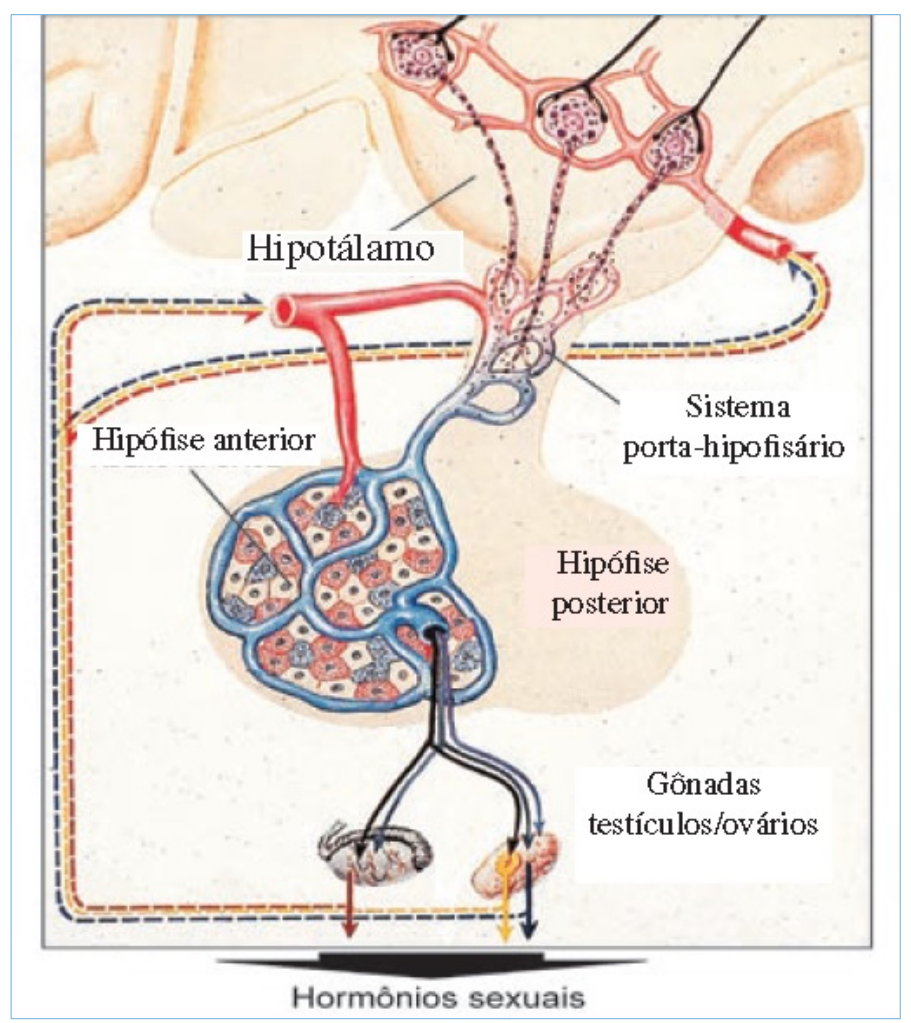

O controle ocorre em três níveis: fatores reguladores hipotalâmicos, hormônios da adenoipófise e hormônios sexuais secretados pelas gônadas. Os fatores reguladores hipotalâmicos alcançam a adenoipófise pelo sistema de vasos porta-hipofisário. Retirado de: Brandão (2004).

\subsection{Aspectos moleculares do sistema opioidérgico, relação com o comportamento maternal e áreas encefálicas envolvidas}

Os receptores opióides têm uma importante participação na interação mãe-filhote (BRIDGES e GRIMM, 1982; FELÍCIO; MANN; BRIDGES, 1991). Os trabalhos conduzidos para a avaliação dos efeitos de opióides no $\mathrm{CM}$ fazem parte de uma linha de pesquisa inicialmente desenvolvida por Miranda-Paiva (1999), porém, poucos trabalhos focaram a biologia molecular dos genes que codificam para os três subtipos de receptores opióides possivelmente envolvidos nesses resultados comportamentais (TEODOROV et al., 2006a, 2008a).

Teodorov et al. (2006) mostraram que os estados fisiológico e reprodutivo, por si só, são capazes de alterar a expressão dos genes que codificam para os receptores opióides em regiões implicadas com o controle do $\mathrm{CM}$ e alteram os produtos protéicos quando as mães são tratadas com cloridrato de morfina do $17^{\circ}$ ao $21^{\circ}$ dias de gestação. Desde o início da década 
de 1970, quando os sítios de ligação específicos para opióides foram descritos, verificou-se uma vasta literatura sobre os receptores de opióides, e seus subtipos (TEODOROV et al., 2006). Assim, os receptores opióides têm sido o foco de intensa pesquisa a fim de elucidar seus papéis em vários processos físiológicos e patológicos, tais como comportamentos motivados, a aprendizagem e a memória, analgesia e dependência, devido a sua vasta distribuição pelo sistema nervoso central e neste contexto a morfina aparece como ferramenta farmacológica clássica por ser um agonista opióide e inespecífico para seus receptores $(\mu, \kappa \mathrm{e}$ $\delta)$.

Há sítios de ligações de receptores opióides estereoespecíficos no SNC, sem uma distribuição uniforme (BROWNSTEIN, 1993). O receptor opióide $\mu$ é amplamente distribuído pelo encéfalo, variando as regiões de maior concentração do receptor de acordo com a espécie. Na PAG existe uma alta densidade de receptores opióides do tipo $\mu$, enquanto que a densidade dos receptores $\kappa$ e $\delta$ são significantemente menores (MANSOUR et al., 1994).

Mann; Kinsley; Bridges, (1991) observaram que a injeção do agonista do receptor opióide $\mu$, DAMGO, i.c.v. em ratas lactantes é capaz de alterar o comportamento maternal de maneira dose-dependente. Os receptores opióides do tipo k tem um papel na imunidade, percepção dolorosa, fisiologia neuroendócrina, podendo modular o comportamento reprodutivo em fêmeas (TEODOROV et al., 2008).

Miranda-Paiva et al. (2001) observaram que a administração repetida de morfina perifericamente em ratas durante o último terço da gestação sensibiliza o animal para os efeitos inibitórios de opióides na expressão do comportamento materno durante a lactação. Ratas expostas a injeções de morfina durante o período perinatal desenvolveram um nível de tolerância médio a droga, que afetou a sensibilidade dos receptores opióides (SOBOR et al., 2011). Moura et al. (2010) demonstraram que infusões de sulfato de morfina na área préóptica medial foram capazes de diminuir o $\mathrm{CM}$, sendo um efeito mediado por receptores opióides (RUBIN; BRIDGES, 1984). O opióide endógeno $\beta$-endorfina injetado via intracerebroventicular (i.c.v.) em ratas inibe a expressão do comportamento materno (Mann et al., 1991), sugerindo que os níveis de opióides endógenos possam influenciar na melhor expressão deste comportamento. A ação combinada de hormônios esteróides como o estradiol e a progesterona resulta em mudanças na ligação de opióides no encéfalo (BRUNTON; RUSSEL1, 2008; SUKIKARA et al., 2011; TEODOROV et al., 2006).

Teodorov et al. (2006) mostraram que em animais não tratado ou tratados com solução salina, Oprm1, o gene que codifica o receptor opióide $\mu$, apresentou uma maior expressão na 
PAG do que em outras regiões do encéfalo analisadas. Nesta área, havia uma ordem de classificação na expressão gênica em que Oprml foi mais expresso, seguido de Oprk1 e Oprd1 (genes que codificam para os receptores opióides k e $\delta$, respectivamente). No estriado, Oprd1 foi o gene mais expresso, seguido Oprm1 e Oprk1. Finalmente, no hipotálamo, Oprk1 foi o gene mais expresso, seguindo Oprm1 e o gene Oprd1.

O mesmo trabalho mostrou que o tratamento agudo com a dose de $20 \mathrm{mg} / \mathrm{kg}$ de sulfato de morfina, apenas a expressão do gene Oprm 1 foi diminuída na PAG. Não foram observadas alterações no estriado e hipotálamo. Isto sugere que a expressão do gene Oprm 1 é mais sensível à estimulação opioidérgica do que os genes que codificam para os outros receptores de opióides, em ratas nulíparas. Consistentemente, relatos recentes sugerem que a inibição induzida pela morfina clássica no $\mathrm{CM}$ pode depender de um estado fisiológico específico (YIM et al., 2006). Com o desenvolvimento de agonistas e antagonistas seletivos, tornou-se evidente que cada tipo de receptor opióide tem propriedades farmacológicas únicas e são diferencialmente distribuídos no sistema nervoso central (MANSOUR et al., 1994, 1995).

A literatura ainda é escassa no que diz respeito ao comportamento dos receptores opióides durante períodos críticos na vida do animal, onde alterações físiológicas importantes ocorrem para que o organismo se adeque a situação para o qual é exigido. Sabe-se que durante a expressão do CM normal em ratas lactantes, os níveis séricos de opióides e o número de receptores opióides na APOM encontram-se reduzidos, enquanto que situação inversa é observada durante o período gestacional (HAMMER; BRIDGES, 1987). Não é claramente conhecido como esses receptores se expressam durante determinados períodos críticos da gestação e lactação em ratas, e no caso da PAG, hipotálamo e estriado esses dados não são conhecidos, assim como não se conhecem os efeitos diretos no desenvolvimento das proles de ratas tratadas com morfina durante os períodos embriogênicos.

Assim, fica clara a importância da modulação opioidérgica do CM em ratas lactantes, bem como a necessidade de investigação molecular do papel dos receptores opióides na PAG, hipotálamo e estriado no contexto desse comportamento e como isso afetaria suas proles enquanto neonatos e depois de adultos. 


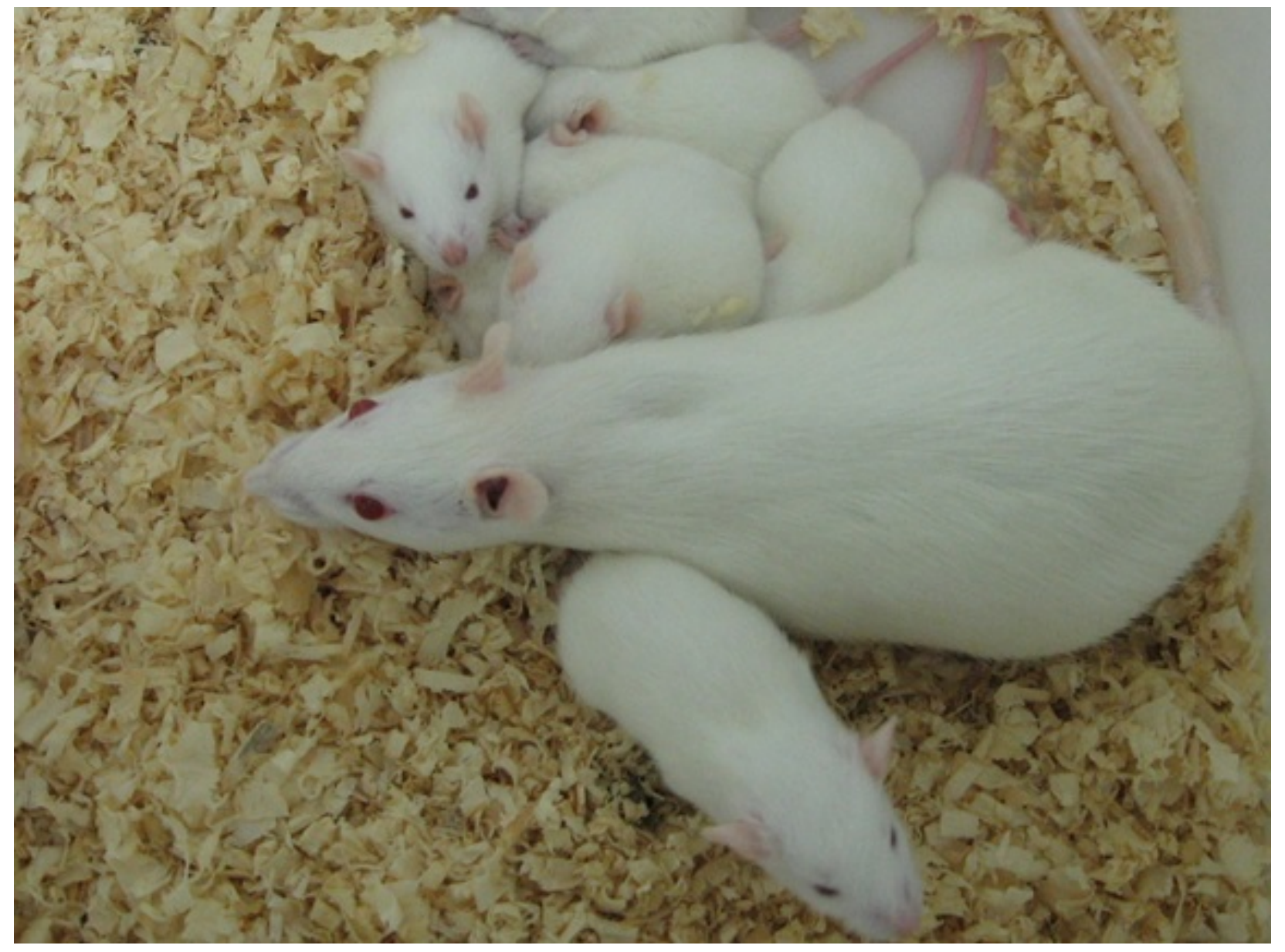

\section{OBJETIVOS}




\subsection{Objetivo geral}

Avaliar os efeitos da administração de sulfato de morfina no primeiro e segundo terços da gestação de ratas no comportamento maternal, em parâmetros físico e neurocomportamental das proles e na biologia molecular de receptores opióides em diferentes regiões encefálicas das mães e das proles.

\subsection{Objetivos específicos}

Avaliar se o tratamento com morfina no primeiro e segundo terços da gestação de ratas:

- Modularia o comportamento maternal

- Alteraria os padrões de desenvolvimento físico e neurocomportamental em ambas as proles;

- Modularia os padrões de expressão gênica e produtos protéicos nas mães e em suas proles nas regiões encefálicas de interesse, sendo estriado, hipotálamo e PAG. 


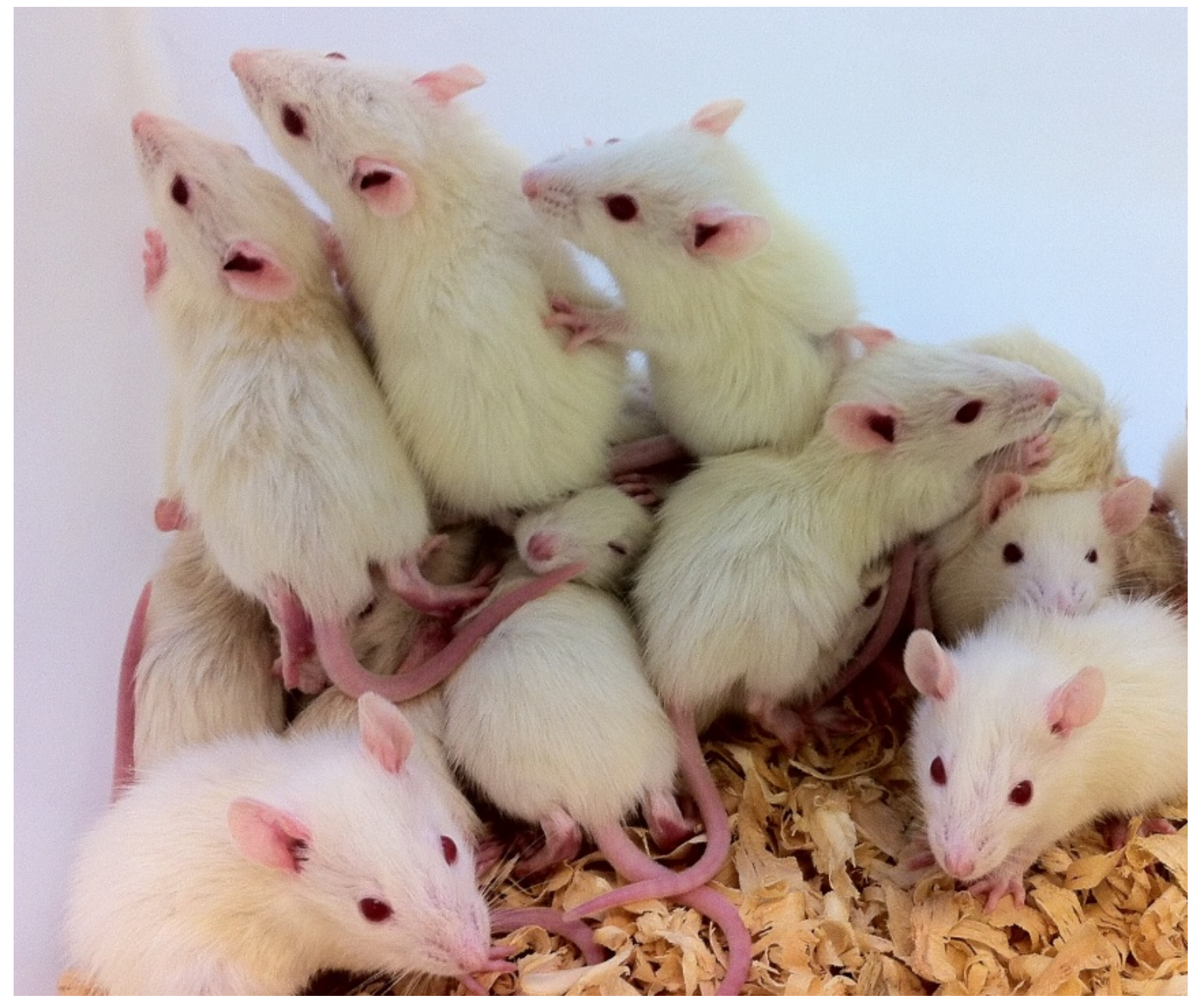

3 MATERIAIS E MÉTODOS 


\subsection{Animais}

Foram utilizadas 80 ratos (Rattus norvegicus) da linhagem Wistar, com aproximadamente 90 dias de idade e peso corporal entre 180 e 250 g no início dos experimentos. Provenientes do Departamento de Patologia da Faculdade de Medicina Veterinária e Zootecnia da Universidade de São Paulo. Os animais foram alojados em gaiolas de polipropileno medindo $30 \times 40 \times 18 \mathrm{~cm}$, em salas com sistema de ventilação $\left(23 \pm 2{ }^{\circ} \mathrm{C}\right)$ e ciclo de luz de $12 \mathrm{~h}$ claro, escuro (luzes acesas as $6 \mathrm{~h}$ ). Água e comida foram fornecidas ad libitum durante todo o experimento. Este estudo está de acordo com os "Princípios Éticos de Experimentação Animal" adotados pela Sociedade Brasileira de Ciência em Animais de Laboratório (SBCAL) e foi aprovado pela Comissão de Ética no Uso de Animais (CEUA) da Faculdade de Medicina Veterinária e Zootecnia (protocolo n. ${ }^{\circ}$ 183/11) e do Instituto de Ciências Biomédicas (protocolo n. ${ }^{\circ} 183$ nas fls. 114 do livro 02), ambas da Universidade de São Paulo.

\subsection{Acasalamento e padronização das ninhadas}

Para o acasalamento 2 ratas em fase de pró-estro/estro foram mantidas com 1 rato sexualmente experiente. Diariamente, no início do período claro do ciclo, foi realizada a análise do lavado vaginal nas fêmeas, e no dia em que era verificada a presença de espermatozoides (Figura 8), este era considerando o dia 1 (um) de prenhes. As ratas gestantes foram mantidas individualmente, em condições de biotério, até o momento do parto e do teste comportamental.

Os partos foram monitorados diariamente até as $14 \mathrm{~h}$, o dia do parto foi considerado como dia 1 (um) de lactação. No dia 2 (dois) de lactação, foram realizadas a contagem e sexagem dos filhotes, de modo que as ninhadas foram padronizadas em oito filhotes, sendo quatro machos e quatro fêmeas por mãe. 
Figura 8 - Lâmina de lavado vaginal contendo espermatozoides (x 400)

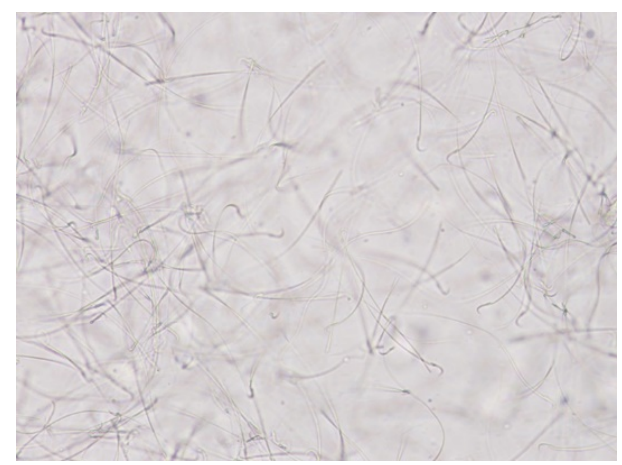

Fonte: Camargo (2010).

\subsection{Drogas}

- Sulfato de Morfina - Cristália ${ }^{\circledR}$ (São Paulo, SP, Brasil)

As doses de morfina durante a gestação foram de $3,5 \mathrm{mg} / \mathrm{kg} /$ dia e a dose desafio foi de $3,0 \mathrm{mg} / \mathrm{kg}$, seguindo-se a avaliação do CM. Para as ratas do grupo controle foi administrada solução salina a $0,9 \%$. A morfina e a solução salina a $0,9 \%$ foram administradas por via s.c. na região dorsal dos animais. As drogas foram preparadas em soluções que permitam injetar um volume de $1,0 \mathrm{ml} . \mathrm{kg}^{-1}$ de peso corporal.

\subsection{Delineamento experimental geral}

Foram estabelecidos dois protocolos para a administração de morfina/salina conforme o períododa gestação:

Protocolo 1: tratamento com morfina/salina do $2^{\circ}$ ao $6^{\circ}$ dias de gestação (Figura 9). No dia $5^{\circ}$ dia de lactação foi administrada a dose desafio, seguido da avaliação do CM Os grupos foram divididos de acordo com o tratamento com 10 animais cada:

- SS (tratamento com salina/ desafio com salina);

- SM (tratamento com salina/ desafio com morfina);

- MS (tratamento com morfina/ desafio com salina);

- MM (tratamento com morfina/ desafio com morfina). 
Figura 9 - Representação esquemática do delineamento experimental do tratamento no $1^{\circ}$ terço da gestação

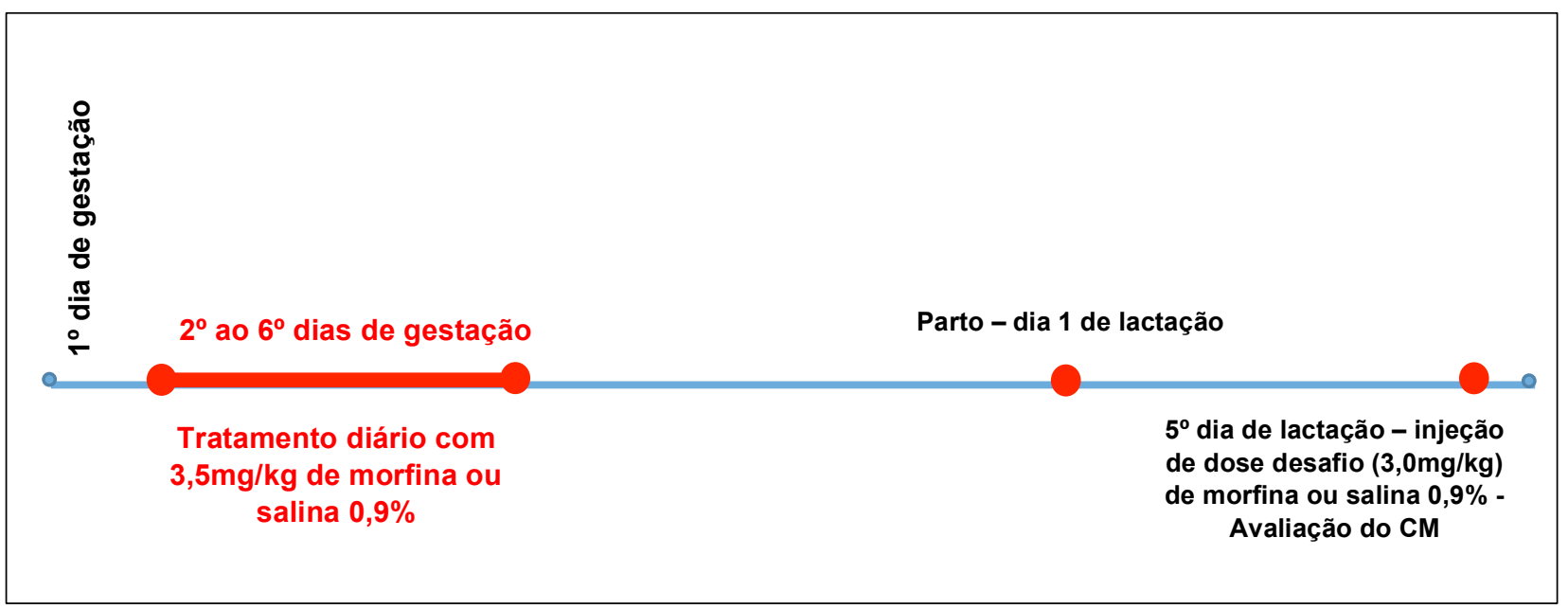

Protocolo 2: tratamento com morfina/salina do $11^{\circ}$ ao $15^{\circ}$ dias de gestação (Figura 9). No dia $5^{\circ}$ dia de lactação foi administrada a dose desafio, seguido da avaliação do CM Os grupos foram divididos de acordo com o tratamento com 10 animais cada:

- SS (tratamento com salina/ desafio com salina);

- SM (tratamento com salina/ desafio com morfina);

- MS (tratamento com morfina/ desafio com salina);

- MM (tratamento com morfina/ desafio com morfina).

Figura 10 - Representação esquemática do delineamento experimental do tratamento no $2^{\circ}$ terço da gestação.

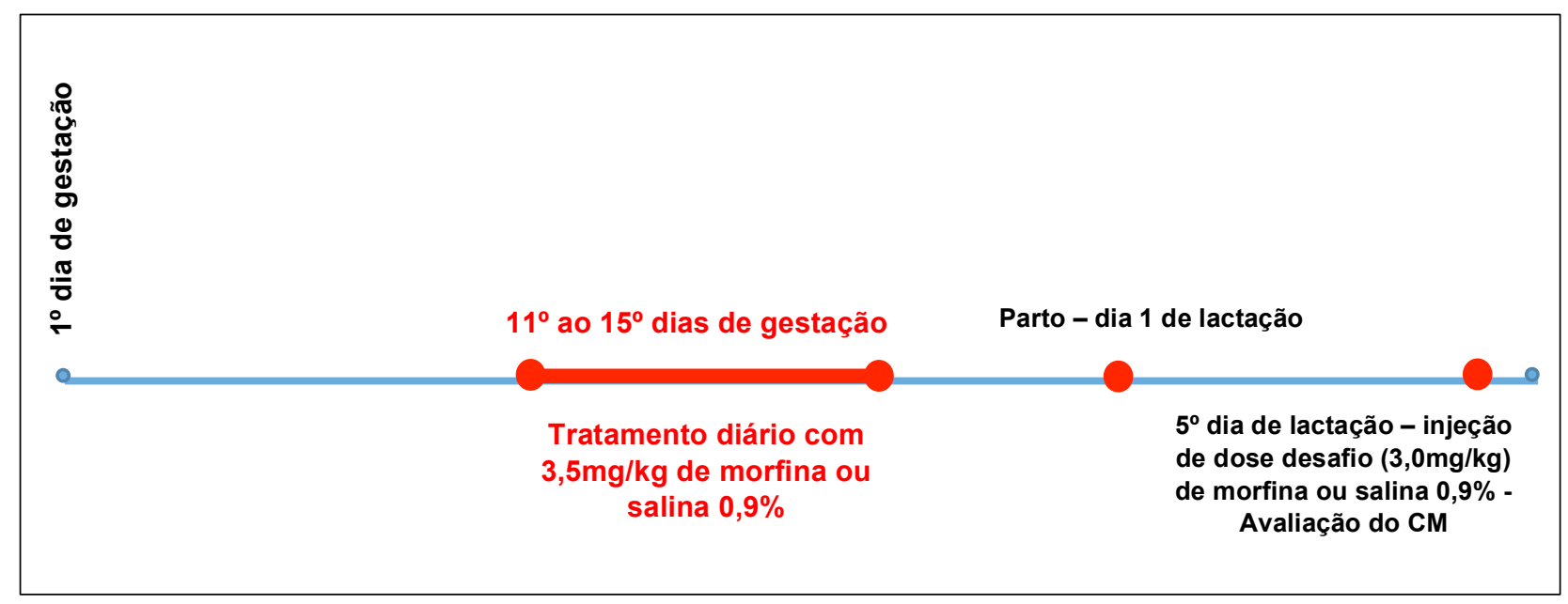




\subsection{Habituação e manipulação dos animais}

Com a finalidade de promover a habituação do animal ao aparato experimental e a manipulação por ele sofrida no dia da avaliação do CM, no dia anterior ao teste, as fêmeas permaneceram durante 30 minutos na gaiola experimental. Este procedimento torna-se essencial, uma vez que o teste não é realizado na gaiola moradia, e sim em uma caixa de acrílico (Figura 11) especialmente projetada para melhor visualização e filmagem dos comportamentos apresentados pelos animais. O tempo de habituação foi igual ao tempo de observação no dia do teste.

Figura 11 - Aparato experimental utilizado para realização e filmagem dos testes comportamentais nas mães.
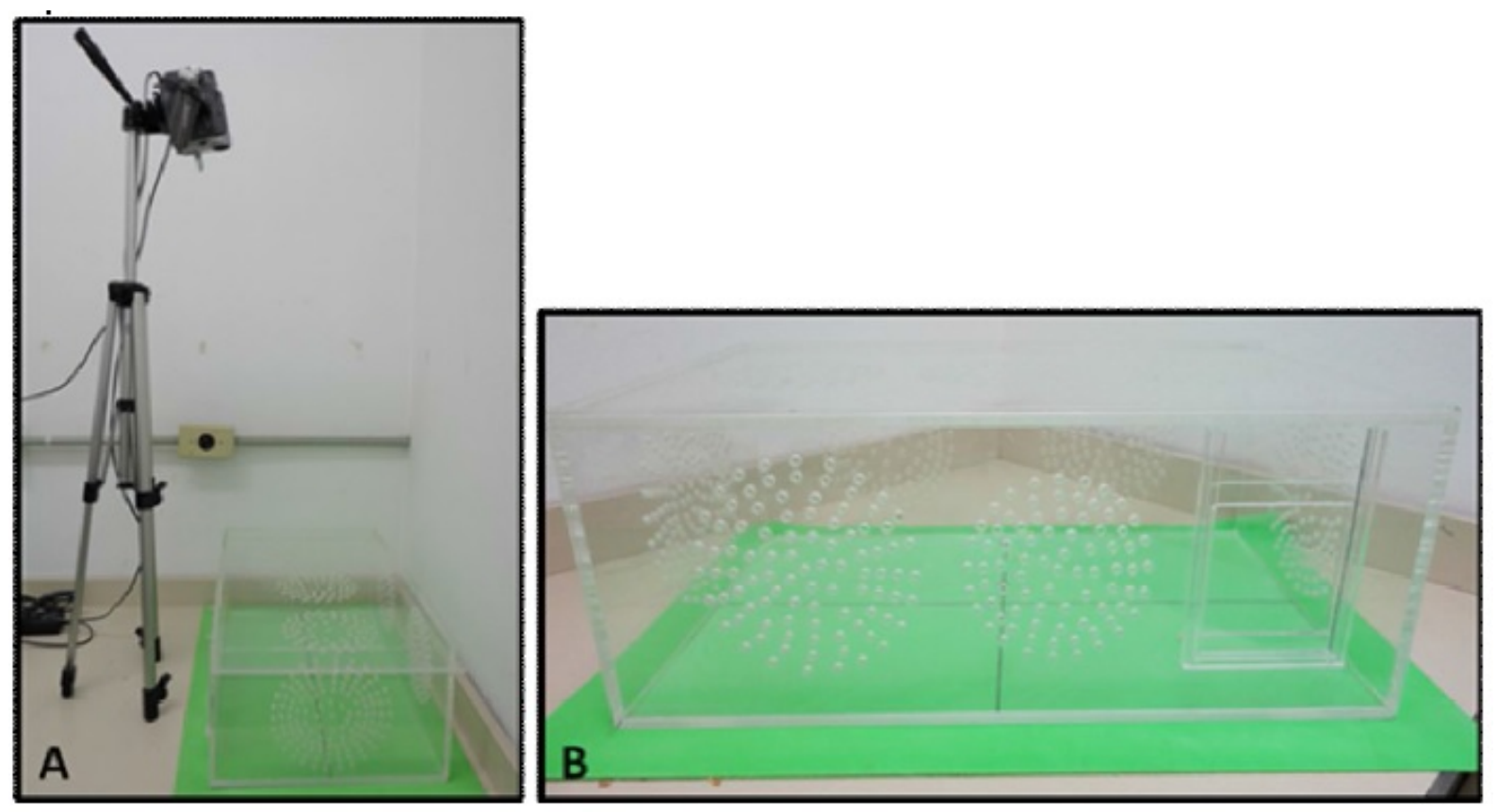

Em (A) tem-se a disposição da câmera para filmagem do comportamento do animal, e em (B) a caixa de acrílico utilizada para o teste. Retirado de Klein (2012).

Após a análise do $\mathrm{CM}$ as ratas sofreram eutanásia por decapitação e o encéfalo foi retirado e lavado em água estéril. Em seguida, as áreas de interesse foram retiradas com bisturi, e acondicionada em freezer $-80{ }^{\circ} \mathrm{C}$ para analise molecular posterior. 


\subsection{Avaliação do comportamento maternal}

O teste comportamental foi realizado ao dia 5 de lactação. Inicialmente foi anotada a posição dos filhotes e da mãe na gaiola moradia, aproximadamente às 9h00. De acordo com a apresentação do ninho, atribuiu-se escores para classificá-lo como fraco, razoável, bom e ótimo. Logo após, a ninhada foi retirada da gaiola, sendo colocada em uma outra gaiola sem maravalha e em outra sala, por onde permaneceu por 1 hora. Trinta minutos após a retirada dos filhotes, a mãe recebeu uma injeção (dose desafio) de sulfato de morfina (3,0 mg/kg), ou solução salina a $0,9 \%$ (até $1 \mathrm{ml} / \mathrm{kg}$ ) conforme o grupo experimental. A observação do CM foi realizada medindo-se:

- Recuperação: Latência, em segundos, para busca dos 8 filhotes colocados nos lados opostos ao ninho dentro da gaiola (Figura 12);

Figura 12 - Recuperação de cada filhote ao início da avaliação do CM

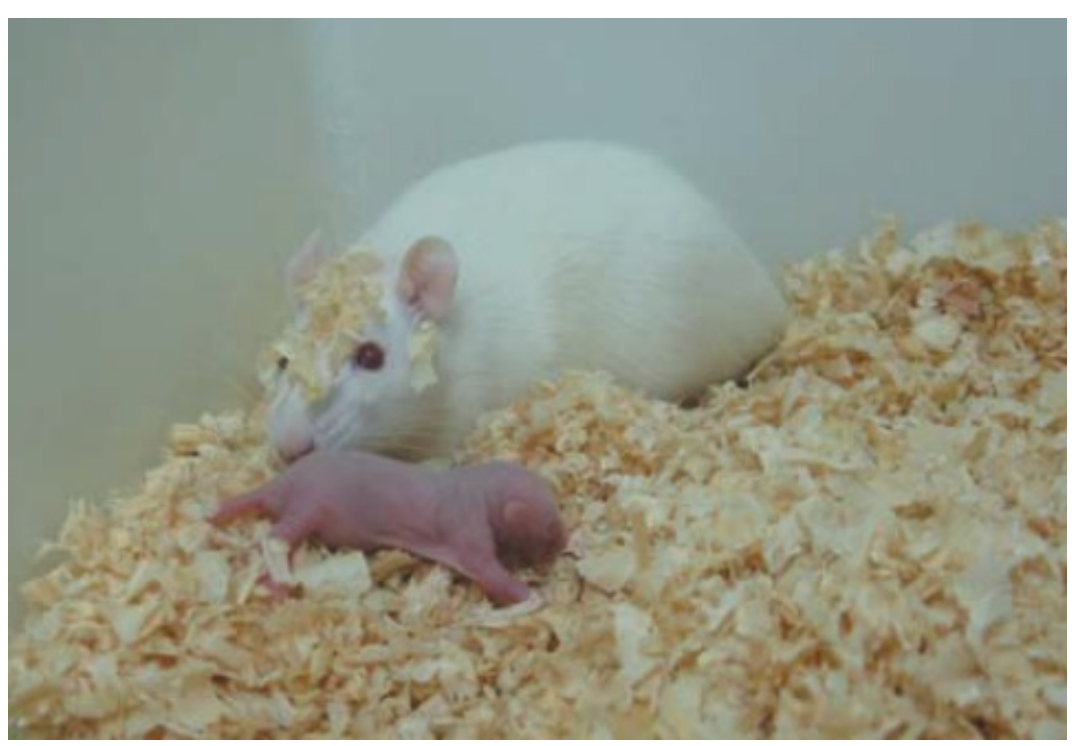

Fonte: Teodorov in Andersen, M.L; Tufik, S. (2010)

- Agrupamento: Latência, em segundos, para agrupar todos os filhotes dentro do ninho (Figura 13); 
Figura 13 - Agrupamento de todos os filhotes no ninho

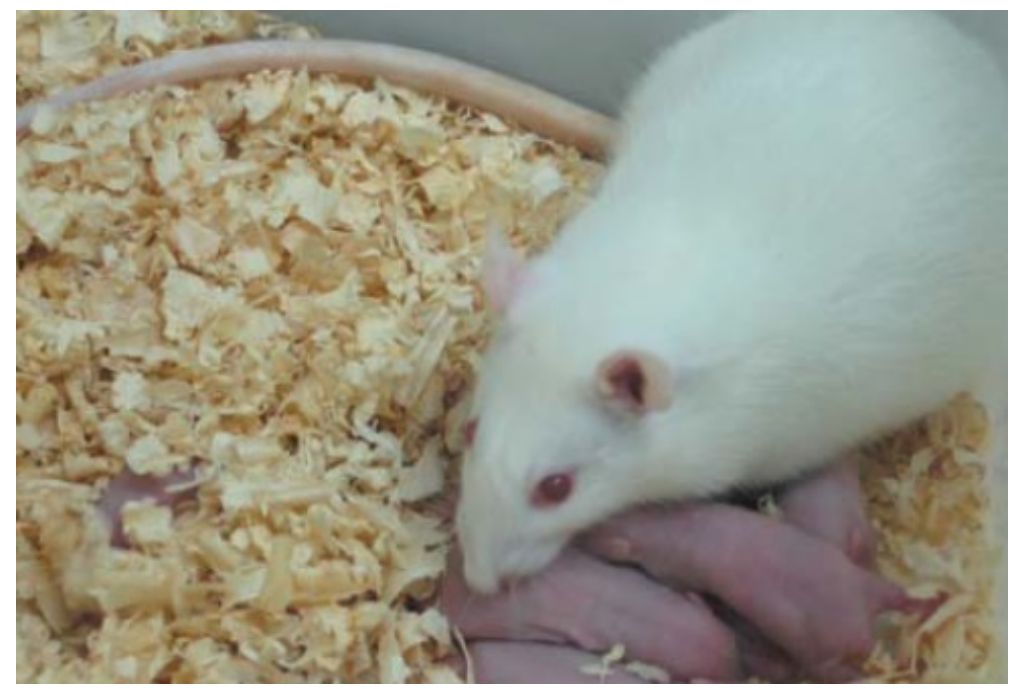

Fonte: Teodorov in Andersen, M.L; Tufik, S. (2010)

- Cifose Fisiológica ou “Crouching”: Latência, em segundos, para a rata ficar sobre a ninhada em posição apropriada à amamentação, com o dorso arqueado (Figura 14);

Figura 14- Cifose fisiológica ou "Crouching" refere-se ao posicionamento da rata sobre os filhotes agrupados a fim de facilitar a amamentação

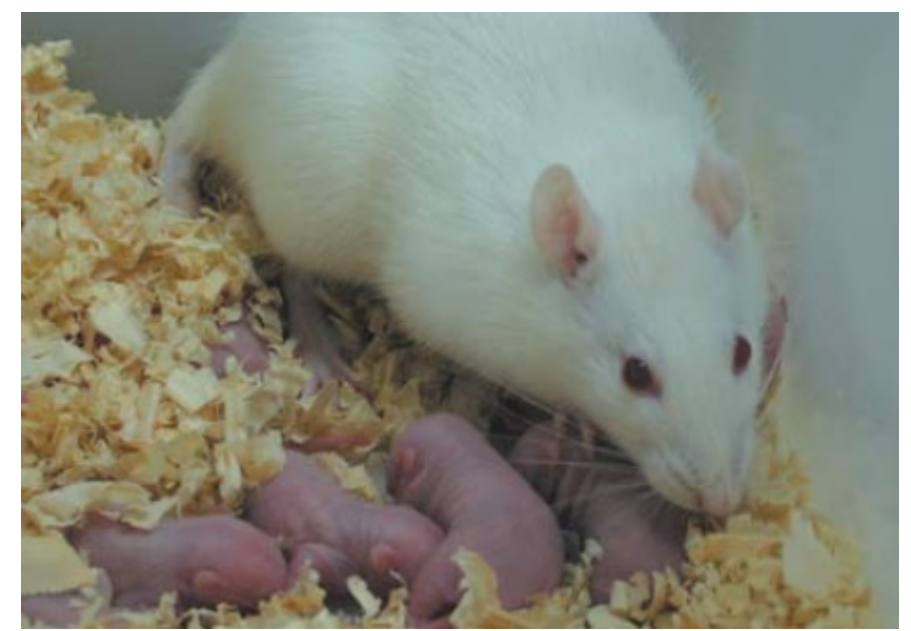

Fonte: Teodorov in Andersen, M.L; Tufik, S. (2010)

- Comportamento Maternal Total (CMT): Latência, em segundos, para comportamento maternal total (CMT), o que significa ficar em posição de amamentação sobre os filhotes por pelo menos 3 minutos consecutivos (Figura 15). 
O CMT foi observado continuadamente até 30 minutos e depois checado aos 45 e 60 minutos. Ratas que não apresentaram o CM durante os 10 primeiros minutos de teste foram retiradas do experimento.

Figura 15 - Comportamento Maternal Total

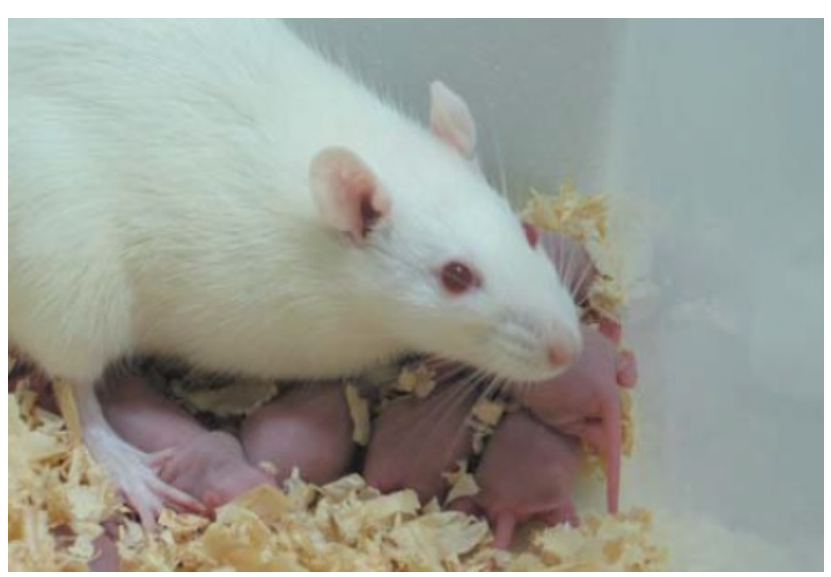

Teodorov in Andersen, M.L; Tufik, S. (2010)

Após a análise do $\mathrm{CM}$ as ratas sofreram eutanásia e as áreas de interesse foram retiradas com bisturi, e acondicionada em freezer $-80^{\circ} \mathrm{C}$ para analise molecular posterior.

\subsection{Avaliação do desenvolvimento físico das proles}

Após o nascimento, foi realizada análise macroscópica seguida da sexagem, sendo 4 filhotes macho e 4 fêmeas por rata, sendo o restante descartado. Os parâmetros avaliados foram:

- Peso em gramas (g): acompanhamento diário do ganho de peso;

- Aparecimento da penugem e pêlos: a observação do aparecimento da penugem se inicia logo ao primeiro dia de vida. O período provável para o aparecimento de penugem compreende do $5^{\circ}$ ao $8^{\circ}$ dias de vida (Figura 16A).

- Desdobramento das orelhas: esse parâmetro foi observado a partir do primeiro dia de vida, até que todos os filhotes tenh

- am a parte superior das duas orelhas descoladas da pele da cabeça, ocorrendo geralmente entre os $2^{\circ}$ e $5^{\circ}$ dias de vida (Figura $16 \mathrm{~B}$ );

- Abertura dos olhos: foi considerada a abertura dos olhos quando o animal apresentar uma fissura longitudinal nas pálpebras dos dois globos oculares. Essa observação ocorre entre os $10^{\circ}$ e $15^{\circ}$ dias de vida (Figura 16C). 
Figura 16 - Rato aos 10 dias de vida.

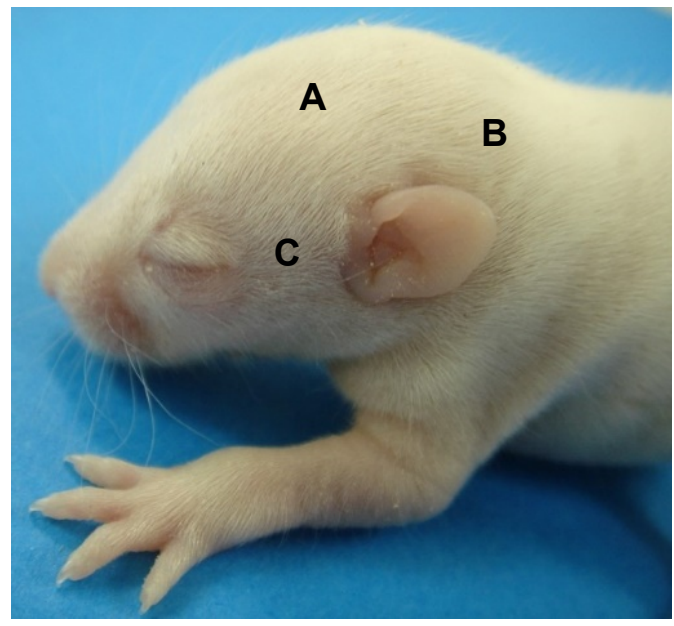

Em (A) pêlos já nascidos, (B) orelhas desdobradas e (C) olhos ainda fechados. Fonte: Camargo (2010).

- Erupção dos dentes incisivos: foi observado o dia em que os dentes superiores e/ou inferiores puderam ser visualizados. Para isso, a boca do animal foi aberta delicadamente afastando-se os lábios e expondo-se a gengiva. Esse parâmetro aparece dos $6^{\circ}$ ao $12^{\circ}$ dias de vida pós-natal;

- Abertura do canal auditivo: esse parâmetro foi observado de modo direto, por meio da constatação do aparecimento do orifício do conduto auditivo externo. Geralmente ocorre por volta dos $12^{\circ}$ e $15^{\circ}$ dias de vida pós-natal;

A observação dos demais parâmetros se fez logo após o desmame, sendo de 21 dias, quando os filhotes foram separados da mãe, foram avaliados:

- Descida dos testículos: para a constatação da presença dos testículos na bolsa escrotal, segurou-se o animal pela porção anterior, de modo que a porção posterior fique completamente livre. O dia da descida dos testículos foi considerado quando se constatou a descida dos dois testículos por apalpação. Essa observação inicia-se entre os $20^{\circ}$ e $35^{\circ}$ dias de vida.

- Abertura da rima vaginal: foi considerada a abertura vaginal quando se constatar, pela observação direta, a presença de um orifício na região genital das fêmeas. Esse parâmetro pode ser visualizado a partir do $30^{\circ}$ dia de vida pós-natal. Ao nascimento será registrada a distância anogenital (mm) com o auxílio de um paquímetro, utilizando-se para tal a média da ninhada. 


\subsection{Avaliação do desenvolvimento neurocomportamental das proles}

Os parâmetros observados para a avaliação do desenvolvimento neurocomportamental foram:

- $\quad$ Resposta de preensão palmar: o animal foi segurado pela porção anterior de modo que suas patas fiquem soltas, e realizada uma leve pressão com um objeto pontiagudo (clipes) no coxim palmar do animal, e esse respondendo com o fechamento de sua pata, envolvendo o objeto;

- Reflexo de endireitamento da postura: o animal foi colocado em decúbito dorsal sobre uma superfície lisa, sendo cronometrado o intervalo de tempo (s) em que o animal consegue voltar para a posição de decúbito ventral, apoiando-se, então, nas quatro patas;

- Reflexo de geotaxia negativa: os filhotes foram colocados em um plano inclinado de 45 graus com a cabeça voltada para baixo (Figura 17), cronometrando-se, então, o tempo de latência (s) necessário para que o animal girasse e se portasse com a cabeça voltada para cima;

- Andar adulto: esse parâmetro foi considerado quando o animal for capaz de se locomover apoiado nas quatro patas sem tocar com o ventre a superfície de apoio, no caso uma mesa.

Figura 17 - Plataforma com inclinação de $45^{\circ}$ para observação da geotaxia negativa.

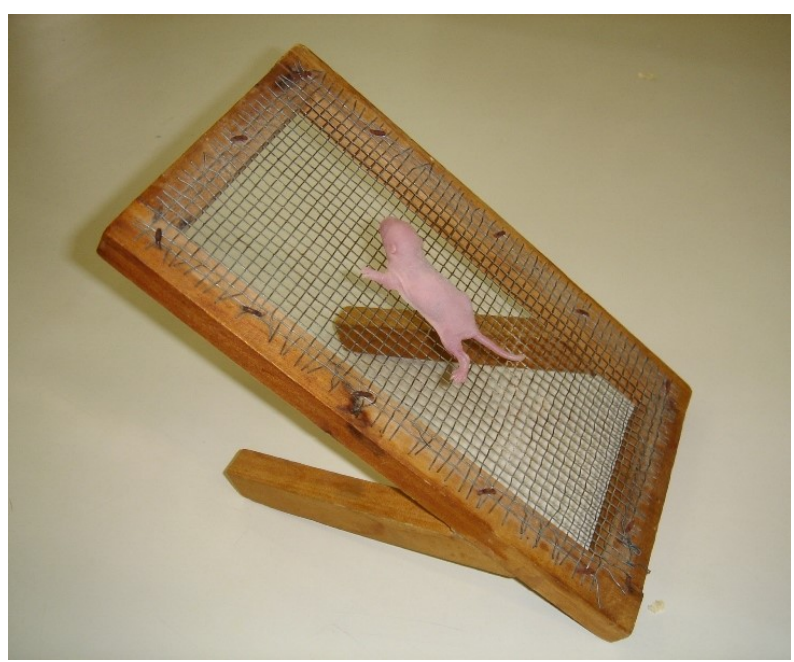

Fonte: Camargo (2010). 


\subsection{Análise da expressão dos genes Oprk1, Oprm1 e Oprd1 dos receptores opióides $\kappa, \mu$ e $\delta$ respectivamente, no estriado, hipotálamo e PAG de ratas suas respectivas proles}

\subsubsection{Extração de RNA total (método de TRIZOL)}

A extração e manipulação do RNA exigem um preparo diferenciado de todo o material, assim como de todas as soluções a serem utilizadas. Assim, a água ultrafiltrada esterilizada em autoclave (120 ${ }^{\circ} \mathrm{C}, 30$ minutos). O tratamento visa eliminar eventuais moléculas de RNAse.

As estruturas encefálicas previamente retiradas de acordo com as coordenadas obtidas no Atlas de Paxinos; Watson (1986) e armazenadas em $-80^{\circ} \mathrm{C}$ foram mergulhadas em $500 \mu \mathrm{l}$ de solução de TRIZOL (Gibco BRL ${ }^{\circledR}$ Carlsbad, Califórnia, EUA) e mantidas em gelo, seguindo-se as especificações do fabricante.

\subsubsection{Ensaio de transcrição reversa (RT-PCR)}

A expressão dos genes Oprm1, Oprk1 e Oprd1 foi investigada por meio de RT-PCR, utilizando-se o Superscript ${ }^{\mathrm{TM}}$ II RNAse H- Reverse Transcriptase (Invitrogen ${ }^{\circledR}$ Carlsbad, Califórnia, EUA). As condições de reação foram estabelecidas de acordo com as indicações do fabricante.

Aos tubos de microcentrífuga contendo $1 \mu \mathrm{g}$ de RNA total tratado com DNAse I, foram adicionados $1 \mu \mathrm{l}$ de oligo DT e $1 \mu \mathrm{l}$ de dNTPs (mistura de $10 \mathrm{mM}$ de cada dNTP Invitrogen $^{\circledR}$ ) e água milliQ até completar um volume de $24 \mu$ l. Essa reação foi incubada por 5 minutos a $65{ }^{\circ} \mathrm{C}$ e depois transferida para gelo. Então foram acrescentados às amostras Superscript buffer 1 x (Superscript II - Invitrogen ${ }^{\circledR}$ ), $2 \mu 1$ de DTT 1M (Invitrogen ${ }^{\circledR}$ ), $1 \mu \mathrm{de}$ RNAseOUT, incubando-se a $42^{\circ} \mathrm{C}$ por 2 minutos em Manteve-se essa temperatura e então foi adicionado $1 \mu \mathrm{l}$ de enzima Superscript II, por mais 50 minutos, seguido de mais 15 minutos à $70{ }^{\circ} \mathrm{C}$. Em seguida foi adicionado $1 \mu \mathrm{l}$ de enzima RNAse $\mathrm{H}$, seguido de incubação por 20 minutos à $37^{\circ} \mathrm{C}$. As amostras do produto obtido (cDNA) foram acondicionadas em freezer $20^{\circ} \mathrm{C}$ até o momento da amplificação. 


\subsection{3 qPCR no Rotor Gene $3000^{\circledR}$}

Após a transcrição reversa foi efetuado o qPCR (PCR em Tempo Real) no aparelho Rotor Gene $3000^{\circledR}$ (Concord, Australia). A qPCR determina o Ct para cada amostra, ou seja, o ciclo de amplificação onde o acúmulo de fluorescência na amostra atinge a linha de detecção arbitrária (threshold). O resultado é coletado durante a fase exponencial de amplificação, que é quando a emissão de fluorescência é proporcional ao número inicial de cópias do produto amplificado, ou concentração da amostra.

Os primers senso e antisenso foram específicos para os genes Oprm1, Oprk1 e Oprd1 em ratos e para o gene $18 \mathrm{~S}$ como controle interno (genes com expressão simular entre os grupos experimentais). O sistema adotado em nosso laboratório para a detecção da expressão gênica foi o sistema Eva Green master Mix (Biotium ${ }^{\circledR}$ São Paulo, SP, Brasil). Neste sistema, além do par de primers, é necessária a utilização de uma sonda que, por ter uma TM mais alta (cerca de $10{ }^{\circ} \mathrm{C}$ de diferença), se hibridizará de forma específica com a fita template antes do par de primers. Todos os procedimentos foram realizados de acordo com as especificações do fabricante. As seqüências utilizadas para a confecção dos primers foram aquelas depositadas no banco público do NCBI (http://www.ncbi.nlm.nih.gov). A empresa Applied Biosystems comercializa os primers e probes.

As reações foram constituídas por $200 \mathrm{nM}$ de primers, água autoclavada estéril e $1 \mathrm{X}$ Eva Green master Mix $\left(\right.$ Biotium $^{\circledR}$ ), otimizados para um volume final de $30 \mu$ l. Para a escolha da concentração ideal de DNA a ser amplificado, foram feitas 6 diluições seriadas do cDNA obtido das amostras, $40 \mathrm{ng}, 20 \mathrm{ng}, 10 \mathrm{ng}, 5 \mathrm{ng}, 2,5 \mathrm{ng}$ e 1,25 ng.

As condições de qPCR utilizadas foram aquelas consideradas as condições universais ótimas da reação pelo fabricante do aparelho, sendo: etapa 1: $50^{\circ} \mathrm{C}, 2$ min.; etapa 2: $95^{\circ} \mathrm{C}$ (desnaturação), 10 min.; etapa 3: $95^{\circ} \mathrm{C}, 15 \mathrm{seg}$.; etapa 4: 60 $\mathrm{C}, 1 \mathrm{~min}$.; etapa 5: voltar à etapa 3 por 35 vezes (para anelamento, extensão e coleta do sinal de fluorescência). O software RG3000 (Corbett Research, Concord, Austrália) foi utilizado para gerar a curva padrão de cada produto de amplificação, as curvas de dissociação, bem como suas análises (Livak; Schmittgen, 2001). 


\subsection{Análise dos produtor protéicos KOR, MOR e DOR dos receptores opióides $\kappa$, $\mu$ e $\delta$ respectivamente, na PAG, estriado e hipotálamo de ratas suas respectivas proles}

\subsubsection{Preparo das amotras}

As estruturas encefálicas previamente retiradas e armazenadas em $-80^{\circ} \mathrm{C}$ foram mergulhadas em Sample Buffer 2x (SDS 10\%, TRIS HCl 1M, pH 6,8, glicerol) com o volume determinado de acordo com o peso da amostra, respeitando a proporção de $100 \mu 1 / 100 \mathrm{mg}$. Após serem sonicadas, receberam o mesmo volume de Working Solution (Sample Buffer 2x, DTT 1M, PMSF $10 \mathrm{mM}$ ). Em seguida as amostras foram centrifugadas a $13.000 \mathrm{rpm}, 15$ minutos a $4^{\circ} \mathrm{C}$. O sobrenadante das amostras foi retirado cuidadosamente e colocado em tubos de microcentrífuga, sendo armazenado em freezer $-80^{\circ} \mathrm{C}$ até o momento das análises.

\subsubsection{Quantificação de proteínas}

Para a quantificação de proteínas, utilizou-se curva padrão em relação a concentrações conhecidas de albumina com o reagente Bradford. As amostras foram acondicionadas em placas elisa e seguiu-se a quantificação em software específico (SoftMax $\mathrm{PRO}^{\circledR}$ ).

\subsubsection{Eletroforese em gel de poliacrilamida sob condições denaturantes}

As frações protéicas foram separadas por eletroforese em um gel de poliacrilamida em tampão Tris glicina na concentração de 10\% tamanho de 10x8 cm Thermo Scientific na presença de SDS, com o auxílio de mini cubas verticais $\left(\right.$ Bio $\operatorname{Rad}^{\circledR}$ ). Os lisados celulares foram solubilizados em um tampão de amostras (TRIS-Base $60 \mathrm{mM}$, glicerol 25\%, SDS 2\%, azul de bromofenol $0,1 \%$, $\beta$-mercapt0oetanol 14,4M), de maneira a depositar a quantidade desejada de proteínas $(10 \mu \mathrm{g})$ em um volume final de $20 \mu \mathrm{l}$ por pocinho.

A migração foi iniciada em um gel de aproximadamente $1,5 \mathrm{~cm}$ de altura (TRIS-Base 1,5 M, pH 8,8; SDS $10 \%$; acrilamida $40 \%$, persulfato de amônia $10 \%$ e TEMED), sob potencial de $110 \mathrm{~V}$. A eletroforese prosseguiu em um gel de separação (TRIS-Base $1 \mathrm{M}, \mathrm{pH}$ 8,8; SDS $10 \%$; acrilamida 40\%, persulfato de amônia 10 \% e TEMED), sob voltagem de 110 $\mathrm{V}$, por 1 hora. A eletroforese foi conduzida em Tampão de Migração (Tris-Base $250 \mathrm{mM}$; SDS $10 \%$; glicina $960 \mathrm{mM}$ ). 


\subsubsection{Eletro-transferência das proteínas}

A eletroforese foi interrompida quando a fronte de migração, visualizada graças ao uso do marcador kaleidoscopio (Bio $\operatorname{Rad}^{\circledR}$ ), atingiu a porção de coloração violeta, correspondente a $40 \mathrm{Kda}$, correspondente a anidrase carbônica. As proteínas do gel então foram transferidas

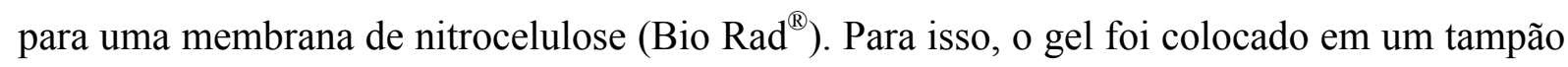
de transferência (TRIS-Base $25 \mathrm{mM}$; glicina $190 \mathrm{mM}$, metanol 10\%), assim como a

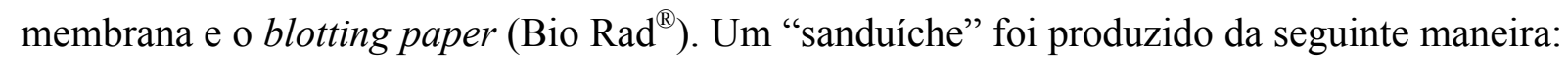
uma folha de boltting paper, o gel de poliacrilamida, a membrana de nitrocelulose, uma outra folha de blotting paper. A transferência ocorreu a $100 \mathrm{~V}$ durante 1 hora a $4{ }^{\circ} \mathrm{C}$ e sob agitação.

\subsubsection{Imunodetecção das proteínas de interesse}

Após o tempo estabelecido para a transferência, a membrana foi lavada em TTBS (Tris $100 \mathrm{mM}, \mathrm{NaCl} 150 \mathrm{mM}$, Tween 20 a 0,05\%) por 10 minutos. Em seguida, a membrana foi incubada durante 1 hora em solução de TTBS acrescida de leite desnatado $5 \%$ (p/vol), temperatura ambiente e agitação constante. Finalmente, a membrana foi incubada com anticorpos primários policlonais anti-rabbit para os receptores opióides MOR (anti- $\mu, 1: 750$,

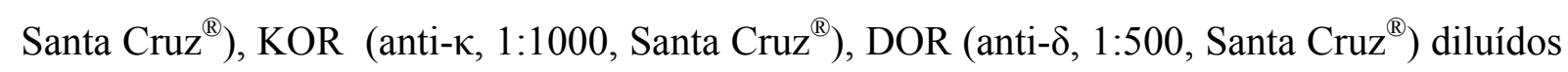
em leite $3 \%$, permanencendo sob agitação constante a $4^{\circ} \mathrm{C}$ e por um período de 18 horas.

No dia seguinte, a membrana foi lavada 2 vezes com TTBS por 10 minutos cada e os anticorpos secundários anti-mouse monoclonais (Santa Cruz ${ }^{\circledR}$ ) diluídos na proporção 1:10.000 (MOR, DOR e KOR) e 1:6.000 ( $\alpha$-TUBULINA) foram aplicados e a membrana incubada durante 1 hora em temperatura ambiente, em agitação constante. Os anticorpos secundários foram removidos e a membrana lavada 2 vezes com TTBS durante 10 minutos e uma lavagem final com TBS por 10 minutos. Em seguida foi realizada a reação de quimioluminescência com kit ECL (Perkin Elmer®) para detecção das proteínas para posterior quantificação. As membranas então foram colocadas em solução do kit por 1 minuto para reação.

3.10.6 Leitura e normalização das proteínas de interesse pelo equipamento MyECL Imager ${ }^{\circledR}$.

Imediatamente após o tratamento das membranas com o reagente quimioluminescente ECL (Thermo Scientific ${ }^{\circledR}$ Nova Zelândia, Austrália), estas foram colocadas no aparelho MyECL Imager (Thermo Scientific ${ }^{\circledR}$ ). O equipamento MyECL Imager ${ }^{\circledR}$ oferece um conjunto completo de alta sensibilidade para revelação de membranas oriundas da técnica de Western 
blot, bem como documentação em gel, por meio de uma interface simplificada e intuitiva touchscreen, convenientes opções de aquisição e software de análise fornecido com o instrumento. O MyECL Imager ${ }^{\circledR}$ incorpora tecnologia avançada de uma câmara CCD que é duas vezes mais sensível que o filme de raios-X. O sensor de imagem pode ser utilizada nos modos "quimioluminescência", "ultravioleta" e "visível” para obtenção das imagens Western blot, além de géis contendo ácido nuclíecos ou proteínas já corados. Cada imagem obtida das membranas contendo as proteínas são posteriormente avaliadas e normalizadas em relação à proteína constitutiva (neste caso alfa-tubulina) por meio do MyECL Imager Acquisition Software ${ }^{\circledR}$.

O software detecta e analisa as bandas automaticamente, podendo comparar até seis imagens simultaneamente. Em seguida pode-se exportar as imagens para Microsoft Excel ${ }^{\circledR}$ ou outro programa para posterior apresentação. É possível determinar o peso molecular das proteínas avaliadas. Os arquivos são posteriormente transferidos para qualquer computador por meio de uma das três portas USB. As Figuras 18A, B e C, demostram a utilização do equipamento e o produto obtido, sendo que em $1 \mathrm{C}$ evidencia-se uma comparação entre o uso de revelação de filmes em cassetes comuns comparados com os dados obtidos com o MyECL. As membranas foram tratadas com ácido acético a 5\% para retirada dos anticorpos.

Figura 18 - Equipamento MyECL Imager ${ }^{\circledR}$.

A

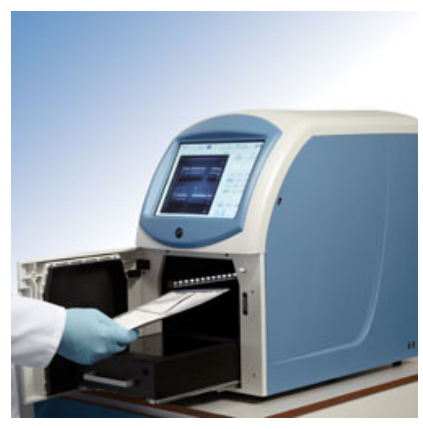

B

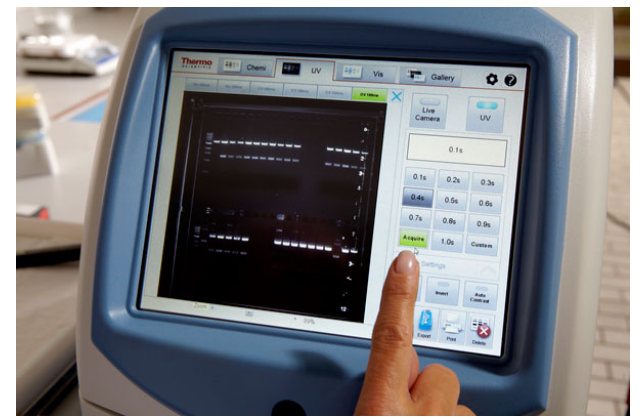

C

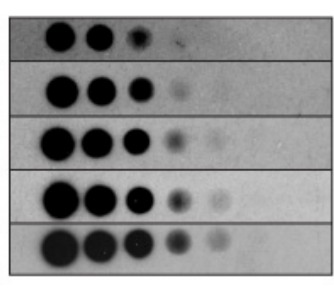

Raio-X

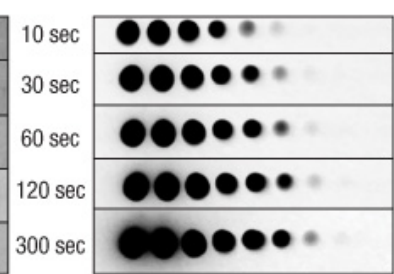

MyECL

Imagem obtida no site da Thermo Scientific (www.piercenet.com) (2013). 


\subsection{Análise estatística}

Empregou-se o programa estatístico GraphPad Prism 5.00 (GraphPad Software, Inc., San Diego, CA, USA) para a realização das análises estatísticas. Para a avaliação dos ninhos foi utilizado o teste exato de Fisher e para todas as outras análises foi utilizada a análise de variância ANOVA de duas vias seguida pelo teste de comparações múltiplas de Bonferroni. Em todas as análises efetuadas, as diferenças foram consideradas significantes quando $\mathrm{p}<0,05$. Os dados estão expressos como média \pm erro padrão. 


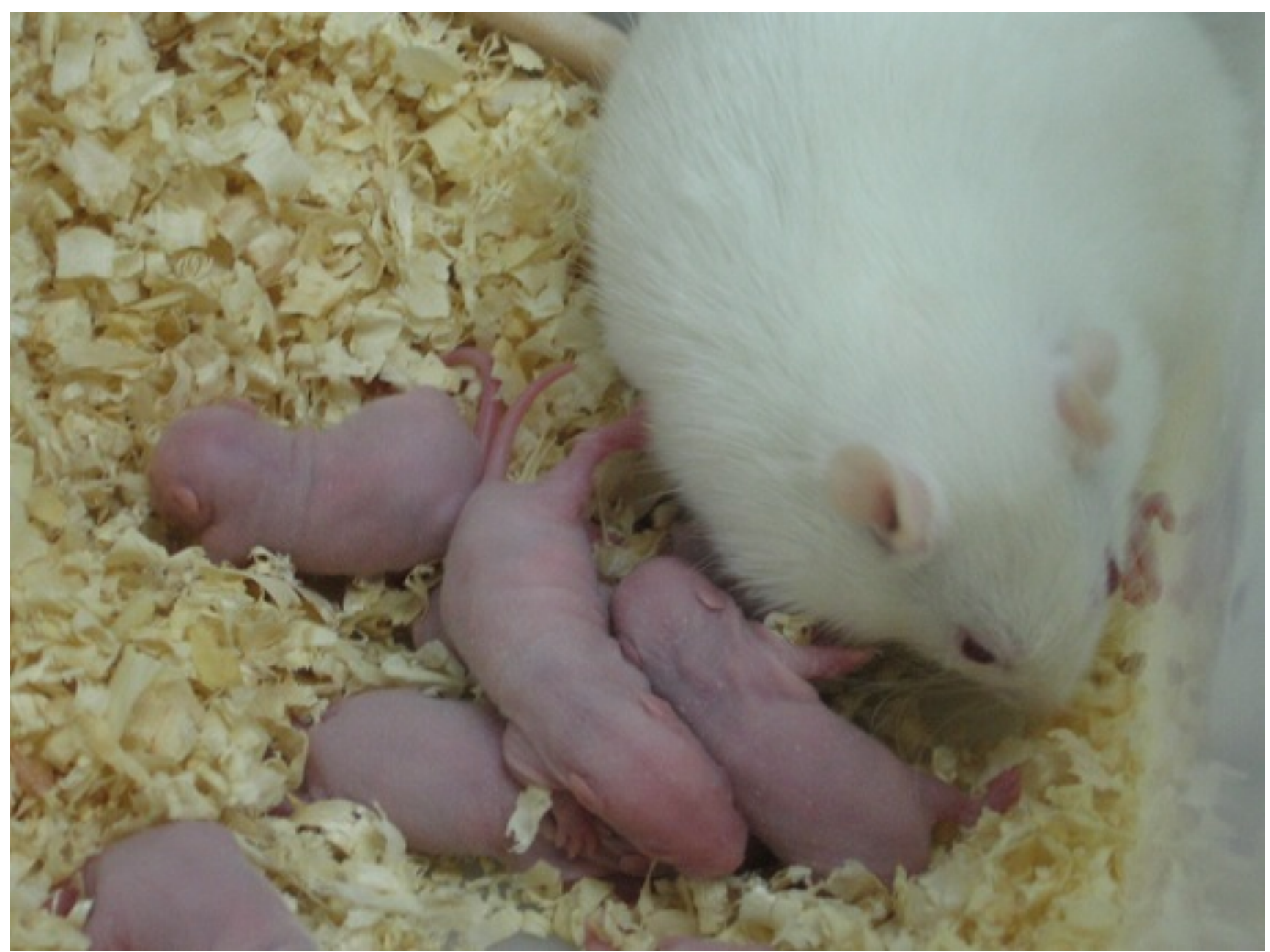

4 RESULTADOS 


\subsection{Experimento 1 - Avaliação do tratamento com sulfato de morfina ou não em diferentes períodos da gestação de ratas no comportamento matenal}

\subsubsection{Delineamento Experimental}

Este experimento avaliou os efeitos do tratamento ou não com sulfato de morfina em fases distintas da gestação, sendo primeiro e segundo terços $\left(2^{\circ}\right.$ ao $6^{\circ}$ dias e $11^{\circ}$ e $15^{\circ}$ dias, conforme descrito anteriormente no item 3.4 de Materiais e Métodos) no CM.

Ao $5^{\circ}$ dia de lactação, pela manhã, realizou-se a avaliação do ninho atribuindo-se escores como ótimo, bom, fraco e razoável. Em seguida filhotes foram retirados da gaiola moradia por 1 hora, sendo que após 30 minutos as mães receberam uma dose desafio de solução salina a $0,9 \%$ ou sulfato de morfina $(3,0 \mathrm{mg} / \mathrm{kg})$. Após 30 minutos das injeções os filhotes foram devolvidos à gaiola de teste em posição oposta à do ninho. Os parâmetros avaliados foram: latência (s) para recuperação de cada filhote, latência (s) para agrupamento dos filhotes na área do ninho, latência (s) para realização do crouching e latência (s) para ocorrência do comportamento maternal total (CMT).

\subsubsection{Resultados}

A análise estatística demonstrou que não houve alterações significantes em relação ao parâmetro de construção do ninho de ratas tratadas no primeiro ou segundo terços da gestação (Tabelas 1 e 2). 
Tabela 1 - Classificação de ninho observado ao $5^{\circ}$ dia de lactação, em ratas tratadas ou não com sulfato de morfina no primeiro terço da gestação.

\begin{tabular}{lcccc}
\hline Grupos/ & SS & SM & MS & MM \\
Classificação & & & & \\
\hline ÓTIMO & 10 & 10 & 10 & 10 \\
BOM & 0 & 0 & 0 & 0 \\
RAZOÁVEL & 0 & 0 & 0 & 0 \\
FRACO & 0 & 0 & 0 & 0 \\
& & & & \\
\hline
\end{tabular}

Tabela 1- Não foram observadas diferenças estatisticamente significantes entre os grupos. São apresentadas as porcentagens para comparação grupo a grupo $(n=10)$ no primeiro terço da gestação. $p>0,05$ - Teste de Fisher.

Tabela 2 - Classificação de ninho observado ao $5^{\circ}$ dia de lactação, em ratas tratadas ou não com sulfato de morfina no primeiro terço da gestação.

\begin{tabular}{lcccc}
\hline $\begin{array}{l}\text { Grupos/ } \\
\text { Classificação }\end{array}$ & SS & SM & MS & MM \\
\hline ÓTIMO & 10 & 8 & 10 & 10 \\
BOM & 0 & 0 & 0 & 0 \\
RAZOÁVEL & 0 & 0 & 0 & 0 \\
FRACO & 0 & 0 & 0 & 0 \\
\hline
\end{tabular}

Tabela 2- Não foram observadas diferenças estatisticamente significantes entre os grupos. São apresentadas as porcentagens para comparação grupo a grupo $(n=10)$ no segundo terço da gestação. $\mathrm{p}>0,05$ - Teste de Fisher. 
A Figura 19 ilustra os parâmetros de recuperação de cada filhote no CM de ratas tratadas ou não com sulfato de morfina no primeiro ou segundo terços da gestação.

A Figura 19A mostra a latência (s) para recuperação do primeiro filhote. A ANOVA de duas vias indicou que o tratamento alterou os resultados $\left[\mathrm{F}_{(3,72)}=5,57, \mathrm{p}=0,0017\right]$ não foi observada diferenças entre os períodos de gestação $\left[\mathrm{F}_{(1,72)}=0,10, \mathrm{p}=0,75\right]$ não foi observada interação entre os fatores $\left[\mathrm{F}_{(3,72)}=0,19, \mathrm{p}=0,90\right]$. O teste de Bonferroni indicou que no segundo terço da gestação as mães dos grupos SM e MM apresentaram aumento significante na latência para buscar o primeiro filhote.

A Figura 19B mostra a latência para recuperação do segundo filhote. A ANOVA de duas vias indicou que o tratamento alterou os resultados $\left.F_{(3,72)}=6,97, p=0,004\right]$ não foi observada diferenças entre os períodos de gestação $\left[\mathrm{F}_{(1,72)}=0,01, \mathrm{p}=0,80\right]$ nem interação entre os fatores $\left[\mathrm{F}_{(3,72)}=0,20, \mathrm{p}=0,89\right]$. O teste de Bonferroni indicou que nos dois períodos da gestação a latência para buscar o segundo filhote de ratas do grupo MS foi maior que daquelas do grupo SS; não houve diferenças significantes neste parâmetro entre os grupos MS e MM, nos dois períodos da gestação.

A Figura 19C mostra a latência para recuperação do terceiro filhote. A ANOVA de duas vias indicou que o tratamento alterou os resultados $\left[F_{(3,72)}=6,43, p=0,0006\right]$ não foi observada diferenças entre os períodos de gestação $\left[\mathrm{F}_{(1,72)}=0,18, \mathrm{p}=0,67\right]$ e não observou-se interação entre os fatores $\left[\mathrm{F}_{(3,72)}=0,65, \mathrm{p}=0,59\right]$. O teste de Bonferroni indicou que no segundo período da gestação os grupos SM e MM apresentaram maior latência para a busca dos filhotes quando comparados com o grupo SS. Além disto, verificou-se que nos dois períodos da gestação, o grupo MS mostram menor latência para a busca dos filhotes que o grupo MS.

A Figura 19D mostra a latência para recuperação do quarto filhote. A ANOVA de duas vias indicou que o tratamento alterou os resultados $\left[F_{(3,72)}=5,52, p=0,002\right]$ não foi observada diferenças entre os períodos de gestação $\left[\mathrm{F}_{(1,72)}=0,67, \mathrm{p}=0,42\right]$ nem interação entre os fatores $\left[\mathrm{F}_{(3,72)}=0,33, \mathrm{p}=0,80\right]$. O teste de Bonferroni indicou que nos dois períodos da gestação o grupo SM apresentou maior latência para a busca do filhote. Além disto, no segundo período da gestação o grupo MS mostrou menor latência para busca do filhote que o grupo MM.

A Figura 19E mostra a latência para recuperação do quinto filhote. A ANOVA de duas vias indicou que o tratamento alterou os resultados $\left[\mathrm{F}_{(3,72)}=3,86, \mathrm{p}=0,01\right]$ não foi observada diferenças entre os períodos de gestação $\left[\mathrm{F}_{(1,72)}=2,2, \mathrm{p}=0,14\right]$ e não observou-se interação 
entre os fatores $\left[\mathrm{F}_{(3,72)}=0,08, \mathrm{p}=0,97\right]$. O teste de Bonferroni indicou que no segundo terço da gestação o grupo MS apresentou menor latência para buscar o filhote em relação ao grupo MS.

A Figura 19F mostra a latência para recuperação do sexto filhote. A ANOVA de duas vias indicou que o tratamento alterou os resultados $\left[F_{(3,72)}=5,96, p=0,001\right]$ não foi observada diferenças entre os períodos de gestação $\left[\mathrm{F}_{(1,72)}=0,54, \mathrm{p}=0,47\right]$ e não observou-se interação entre os fatores $\left[\mathrm{F}_{(3,72)}=0,49, \mathrm{p}=0,69\right]$. O teste de Bonferroni indicou que no segundo terço da gestação os animais dos grupos SM e MM apresentaram maior latência para a busca do filhote em relação ao grupo SS. Por outro lado, no primeiro terço da gestação, o grupo MS apresentou menor latência para a busca do filhote que aqueles animais do grupo SM.

A Figura 19G mostra a latência para recuperação do sétimo filhote. A ANOVA de duas vias indicou que o tratamento alterou os resultados $\left[\mathrm{F}_{(3,72)}=3,45, \mathrm{p}=0,01\right]$ não foi observada diferenças entre os períodos de gestação $\left[\mathrm{F}_{(1,72)}=0,41, \mathrm{p}=0,41\right]$ e não observou-se interação entre os fatores $\left[\mathrm{F}_{(3,72)}=0,29, \mathrm{p}=0,84\right]$. O teste de Bonferroni indicou que os animais do grupo MS apresentaram menor latência para a busca do filhote que os animais do grupo MM.

A Figura $19 \mathrm{H}$ mostra a latência para recuperação do oitavo filhote. A ANOVA de duas vias indicou que o tratamento alterou os resultados $\left[\mathrm{F}_{(3,72)}=2,78, \mathrm{p}=0,05\right]$ não foi observada diferenças entre os períodos de gestação $\left[\mathrm{F}_{(1,72)}=0,08, \mathrm{p}=0,78\right]$ e não observou-se interação entre os fatores $\left[\mathrm{F}_{(3,72)}=0,20, \mathrm{p}=0,89\right]$. O teste de Bonferroni não indicou diferenças entre os diferentes grupos.

A Figura 20 ilustra os parâmetros de agrupamento dos filhotes, crounching e CMT referente ao comportamento maternal de ratas tratadas ou não com sulfato de morfina no primeiro ou segundo terços da gestação.

Na Figura 20A, a ANOVA de duas vias não indicou a existência de diferenças significantes no agrupamento dos filhotes entre os tratamentos $\left.\mathrm{F}_{(3,72)}=0,35, \mathrm{P}=0,79\right]$, não observou-se diferenças significantes entre os períodos da gestação $\left[\mathrm{F}_{(1,72)}=0,20, \mathrm{p}=0,65\right]$ não foi observada interação entre os fatores $\left[\mathrm{F}_{(3,72)}=0,60, \mathrm{p}=0,62\right]$.

$\mathrm{Na}$ Figura 20B, onde se observa a latência para o crouching das ratas dos diferentes grupos. A ANOVA de duas vias não indicou a existência de diferenças significantes no agrupamento dos filhotes entre os tratamentos $\left[\mathrm{F}_{(3,72)}=0,17, \mathrm{p}=0,92\right]$, mas foi observada 
diferenças entre os períodos da gestação $\left[\mathrm{F}_{(1,72)}=11,05, \mathrm{p}=0,001\right]$ não foi observada interação entre os fatores $\left[\mathrm{F}_{(3,72)}=1,71, \mathrm{p}=0,17\right]$.

Na Figura 20C, a ANOVA de duas vias não indicou a existência de diferenças significantes no CMT entre os tratamentos $\left[\mathrm{F}_{(3,72)}=0,88, \mathrm{p}=0,46\right]$, não foi observada diferenças entre os períodos da gestação $\left[\mathrm{F}_{(1,72)}=0,80, \mathrm{p}=0,37\right]$ não observou-se interação entre os fatores $\left[\mathrm{F}_{(3,72)}=0,10, \mathrm{p}=0,96\right]$. 
Figura 19 - Avaliação do parâmetro de recuperação de cada filhote referente do comportamento maternal de ratas tratadas ou não com sulfato de morfina no primeiro ou segundo terços da gestação.

A

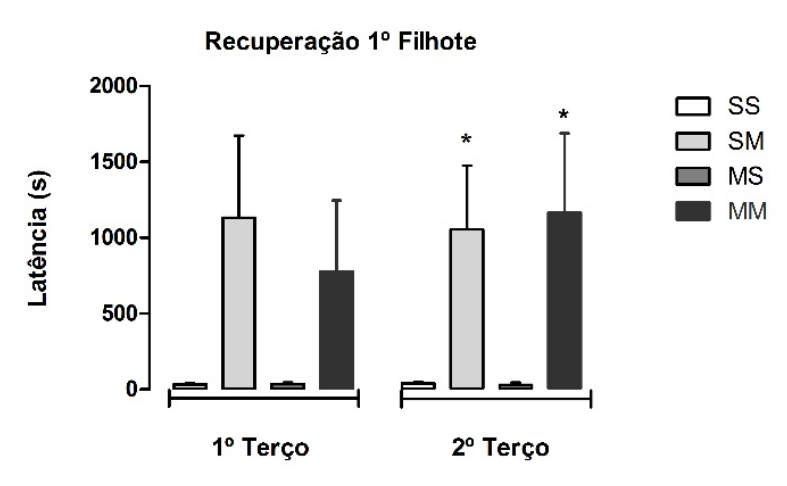

C

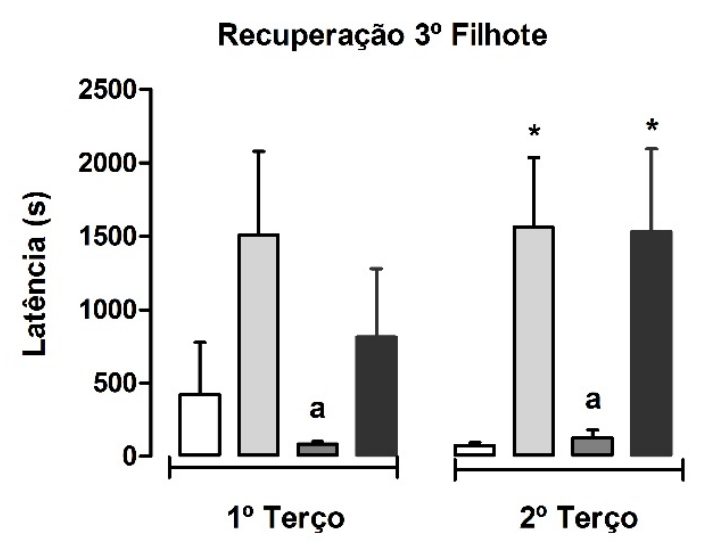

B

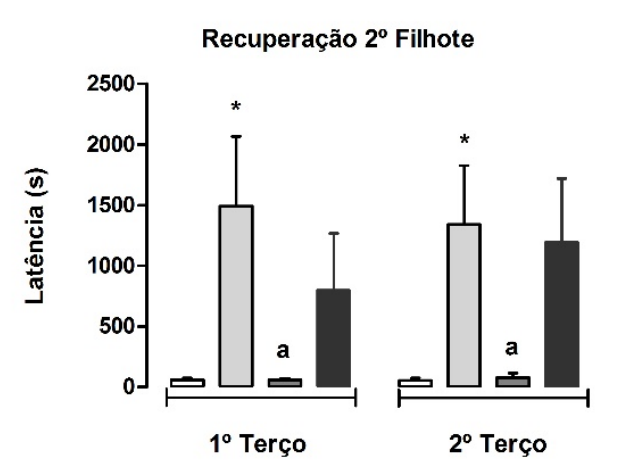

D

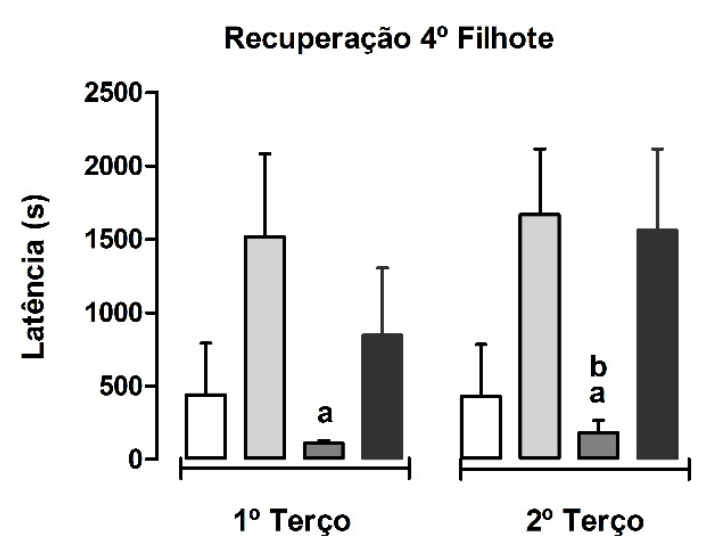



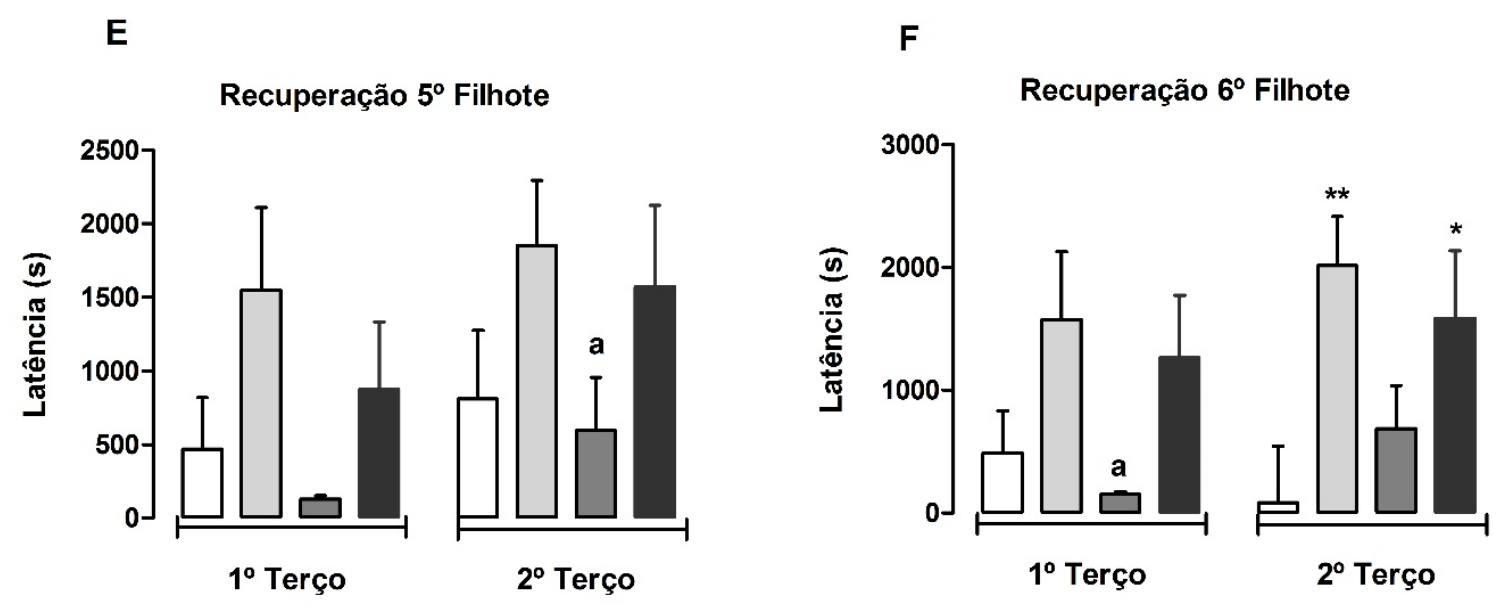

G

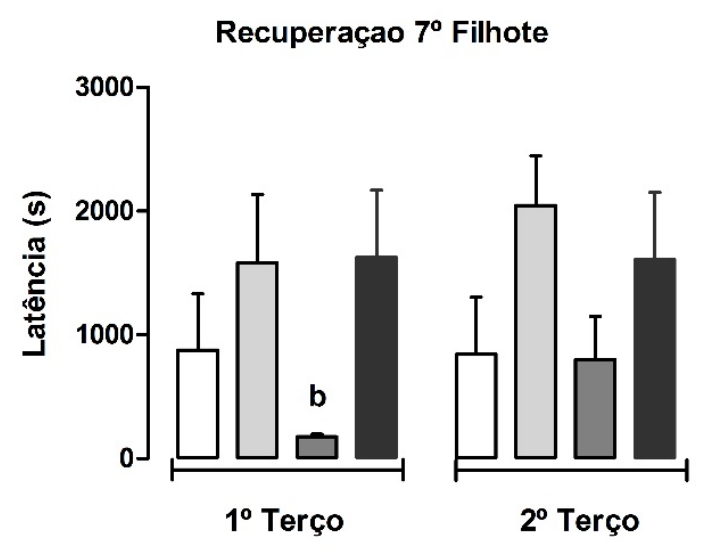

H

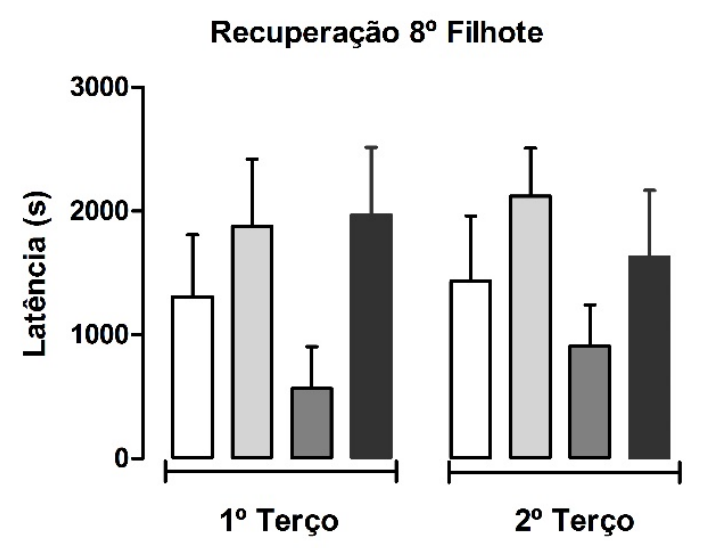


Em (A), latência (s) para a recuperação do $1^{\circ}$ filhote. (B), latência (s) para a recuperação do $2^{\circ}$ filhote, em (C), latência (s) para a recuperação do $3^{\circ}$ filhote. Em (D), latência (se) para a recuperação do $4^{\circ}$ filhote, em (E), latência (s) para a recuperação do $5^{\circ}$ filhote. Em (F), latência (s) para a recuperação do $6^{\circ}$ fillhote, em $(\mathrm{G})$, latência (s) para a recuperação do $7^{\circ}$ filhote e $(\mathrm{H})$, latência (s) para a recuperação do $8^{\circ}$ filhote. SS: tratamento durante a gestação com salina $0,9 \%$ e desafio no $5^{\circ}$ dia de lactação com salina $0,9 \%$; SM: tratamento durante a gestação com salina $0,9 \%$ e desafio no $5^{\circ}$ dia de lactação com 3,0mg/kg de sulfato de morfina; MS: tratamento durante a gestação com $3,5 \mathrm{mg} / \mathrm{kg}$ de sulfato de morfina e desafio no $5^{\circ}$ dia de lactação com salina $0,9 \%$; MM: tratamento durante a gestação com $3,5 \mathrm{mg} / \mathrm{kg}$ de sulfato de morfina e desafio no $5^{\circ}$ dia de lactação com $3,0 \mathrm{mg} / \mathrm{kg}$ de sulfato de morfina. Os dados são apresentados como médias e erros-padrão $(n=10)$. Anova de duas vias seguida pelo teste de Bonferroni. * diferença significante em relação ao grupo SS; a - diferença significante em relação ao grupo SM; b- diferença significante em relação ao grupo MM. 
Figura 20 - Avaliação dos parâmetros de agrupamento dos filhotes, crounching e CMT referente ao comportamento maternal de ratas tratadas ou não com sulfato de morfina no primeiro ou segundo terços da gestação.

A

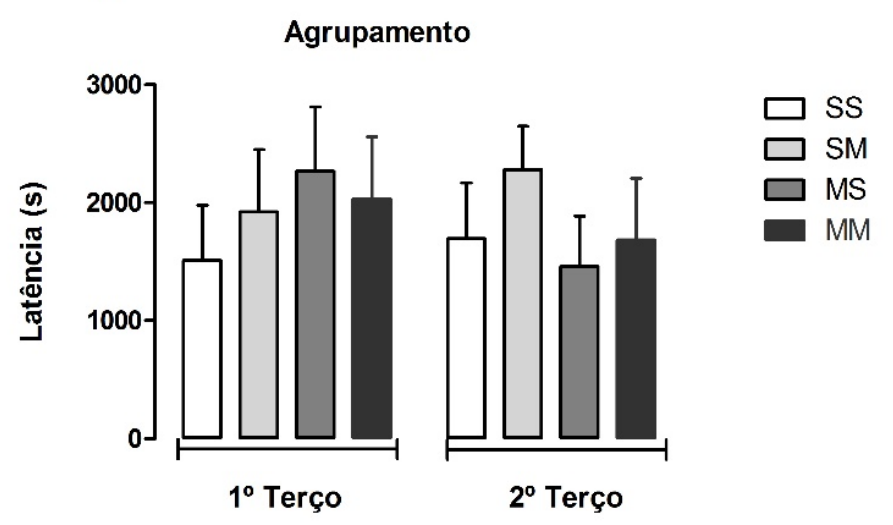

B

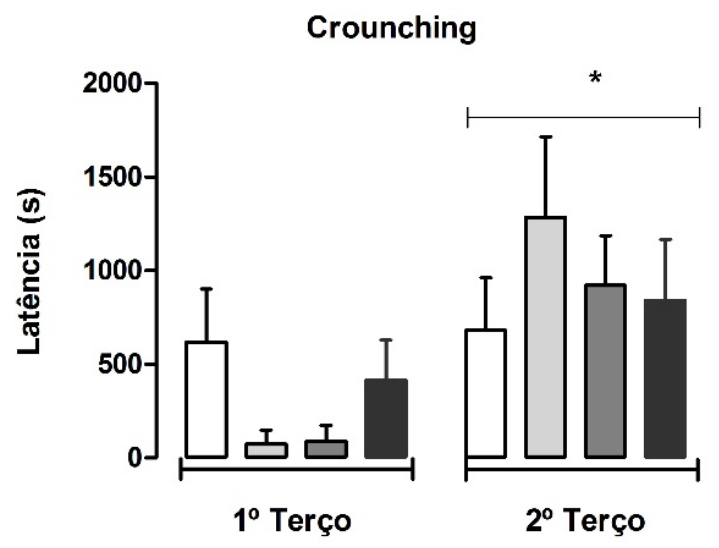

C

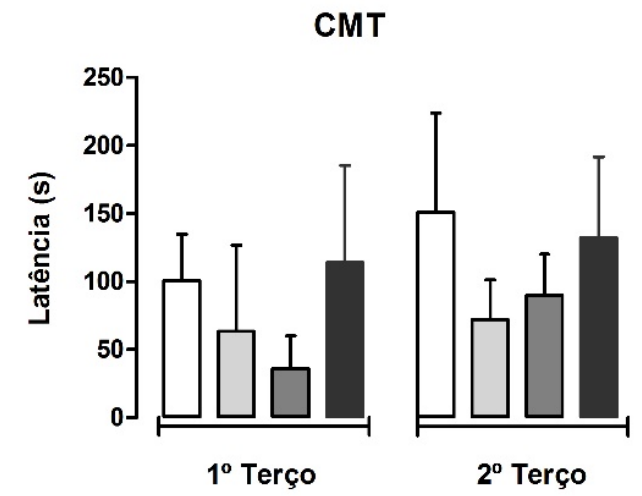


Em (A), latência em segundos para o agrupamento de todos os filhotes no ninho; (B) latência em segundos em que a rata realizou cifose fisiológica (Crouching) sobre os filhotes e em (C) quando a mãe permaneceu por 3 minutos ou mais minutos consecutivos em cifose fisiológica. SS: tratamento durante a gestação com salina $0,9 \%$ e desafio no $5^{\circ}$ dia de lactação com salina $0,9 \%$; SM: tratamento durante a gestação com salina $0,9 \%$ e desafio no $5^{\circ}$ dia de lactação com $3,0 \mathrm{mg} / \mathrm{kg}$ de sulfato de morfina; MS: tratamento durante a gestação com $3,5 \mathrm{mg} / \mathrm{kg}$ de sulfato de morfina e desafio no $5^{\circ}$ dia de lactação com salina $0,9 \%$; MM: tratamento durante a gestação com $3,5 \mathrm{mg} / \mathrm{kg}$ de sulfato de morfina e desafio no $5^{\circ}$ dia de lactação com $3,0 \mathrm{mg} / \mathrm{kg}$ de sulfato de morfina. Os dados são apresentados como médias e erros-padrão $(\mathrm{n}=10)$. Todas as análises foram realizadas por ANOVA de duas vias seguida pelo teste de Bonferroni. * - diferença significante entre os períodos da gestação. 


\subsection{Experimento 2 - Avaliação do peso corporal das proles de ratas tratadas ou não com sulfato de morfina no primeiro ou segundo terços da gestação}

\subsubsection{Delineamento Experimental}

As proles feminina e masculina de ratas foram pesadas desde o dia do nascimento até o dia 21 (desmame) diariamente. Os pesos corporais também foram tomados aos 45 (puberdade) e 60 dias de vida (adulto), sendo calculado o ganho de peso (g), utilizando-se balança semi-analítica. Utilizou-se a média das ninhadas para ambas as proles.

\subsubsection{Resultados}

As Figuras 21, 22, 23 e 24 ilustram o ganho de peso corporal das ninhadas das proles feminina e masculina de ratas tratadas ou não com sulfato de morfina no primeiro ou segundo terços da gestação. Serão apresentados primeiramente os dados da prole feminina e em sequência os resultados da prole masculina.

A Figura 21A, mostra o peso da ninhada da prole feminina aos 21 dias de vida na qual verificou-se que o tratamento não alterou os resultados $\left[\mathrm{F}_{(3,72)}=0,74, \mathrm{p}=0,53\right]$, não observou-se diferenças significantes entre os períodos da gestação $\left[\mathrm{F}_{(1,72)}=2,12, \mathrm{p}=0,15\right]$ não foi observada interação entre os fatores $\left[\mathrm{F}_{(3,72)}=1,09, \mathrm{p}=0,36\right]$. O teste de Bonferroni não indicou diferenças significantes entres os diferentes grupos.

Na Figura 21B, que ilustra o peso da prole feminina aos 45 dias de vida, o tratamento não alterou os resultados $\left[\mathrm{F}_{(3,72)}=1,81, \mathrm{p}=0,15\right]$, porém observou-se diferenças significantes entre os períodos da gestação $\left[\mathrm{F}_{(1,72)}=28,45, \mathrm{p}<0,0001\right]$, e foi observada interação entre os fatores $\left[\mathrm{F}_{(3,72)}=3,48, \mathrm{p}=0,02\right]$. O teste de Bonferroni indicou que as proles dos grupos SM e MM apresentaram um aumento no ganho de peso em relação ao grupo SS no primeiro terço da gestação.

O peso da ninhada da prole feminina aos 60 dias (Figura 21C) não sofreu alteração devido ao tratamento $\left[\mathrm{F}_{(3,72)}=1,39, \mathrm{p}=0,25\right]$, porém observou-se diferenças significantes entre os períodos da gestação $\left[\mathrm{F}_{(1,72)}=5,60, \mathrm{p}=0,02\right]$, e foi observada interação entre os fatores $\left[\mathrm{F}_{(3,72)}=3,20, \mathrm{p}=0,03\right]$. O teste de Bonferroni indicou que as proles do grupo MM apresentaram uma diminuição no ganho de peso em relação ao grupo SS no primeiro terço da gestação. 
A Figura 22 ilustra o ganho de peso total das proles femininas nos diferentes períodos de tratamento na gestação. A ANOVA de duas vias não indicou diferenças significantes quanto ao tratamento $\left[\mathrm{F}_{(3,72)}=0,58, \mathrm{p}=0,69\right]$ não foram observadas diferenças significantes entre os períodos da gestação $\left[\mathrm{F}_{(1,72)}=2,99, \mathrm{p}=0,08\right]$ e não foi observada interação entre os fatores $\left[\mathrm{F}_{(3,72)}=0,45, \mathrm{p}=0,63\right]$. O teste de Bonferroni não indicou diferenças significantes entres os diferentes grupos.

A Figura 23A mostra o peso da ninhada da prole masculina aos 21 dias de vida onde verificou-se que o tratamento alterou os resultados $\left[\mathrm{F}_{(3,72)}=4,45, \mathrm{p}=0,006\right.$, porém não foram observadas diferenças significantes entre os períodos da gestação $\left[\mathrm{F}_{(1,72)}=1,78, \mathrm{p}=0,18\right]$ e não foi observada interação entre os fatores $\left[\mathrm{F}_{(3,72)}=0,59, \mathrm{p}=0,62\right]$. O teste de Bonferroni indicou que as proles do grupo MM apresentaram um aumento no peso em relação ao grupo SS no segundo terço da gestação.

Na Figura 23B, que ilustra o peso da prole masculina aos 45 dias de vida, o tratamento alterou os resultados $\left[\mathrm{F}_{(3,72)}=31,04, \mathrm{p}<0,0001\right]$, foram observadas diferenças significantes entre os períodos da gestação $\left[\mathrm{F}_{(1,72)}=38,20, \mathrm{p}<0,0001\right]$, e foi observada interação entre os fatores $\left[\mathrm{F}_{(3,72)}=21,67, \mathrm{p}<0,0001\right]$. O teste de Bonferroni indicou que as proles do grupo MM apresentaram um aumento no peso em relação aos grupo SS, SM e MS no segundo terço da gestação.

O peso da prole masculina aos 60 dias (Figura 23C) não sofreu alteração devido ao tratamento $\left[\mathrm{F}_{(3,72)}=1,25, \mathrm{p}=0,29\right]$, porém foram observadas diferenças significantes entre os períodos da gestação $\left[\mathrm{F}_{(1,72)}=1,34, \mathrm{p}=0,25\right]$, e foi observada interação entre os fatores $\left[\mathrm{F}_{(3,72)}\right.$ $=7,33, \mathrm{p}=0,0002]$. O teste de Bonferroni indicou que:

1) As proles do grupo SM no primeiro terço da gestação apresentaram um diminuição no peso e no segundo terço apresentaram um aumento no peso em relação aos grupos SS em ambos os terços da gestação;

2) As proles do grupo $\mathrm{MM}$ apresentaram um aumento no peso em relação ao grupo controle no segundo terço da gestação;

3) As proles do grupo MM apresentaram um aumento no peso em relação ao grupo SM no segundo terço da gestação;

A Figura 24 ilustra o ganho de peso total da prole masculina nos diferentes períodos de tratamento na gestação. A ANOVA de duas vias não indicou diferenças significantes quanto ao tratamento[ $\left[\mathrm{F}_{(3,72)}=1,96, \mathrm{p}=0,13\right]$ não foram observadas diferenças significantes 
entre os períodos da gestação $\left[\mathrm{F}_{(1,72)}=0,56, \mathrm{p}=0,46\right]$ não foi observada interação entre os fatores $\left[\mathrm{F}_{(3,72)}=1,09, \mathrm{p}=0,36\right]$. 
Figura 21 - Avaliação do ganho de peso das ninhadas femininas de ratas tratadas ou não com sulfato de morfina no primeiro ou segundo terços da gestação.

A

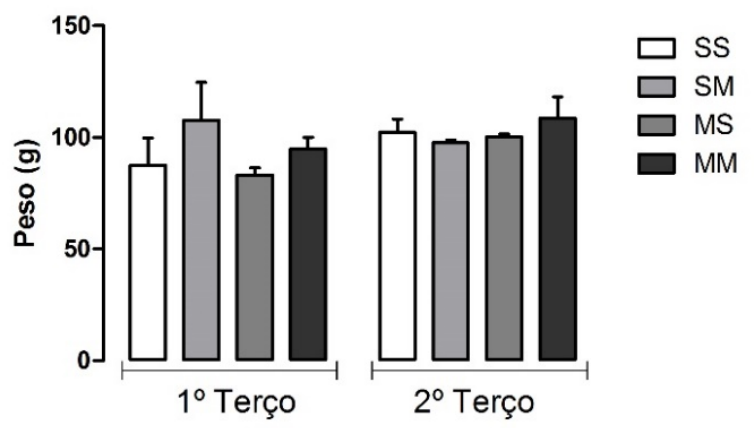

B

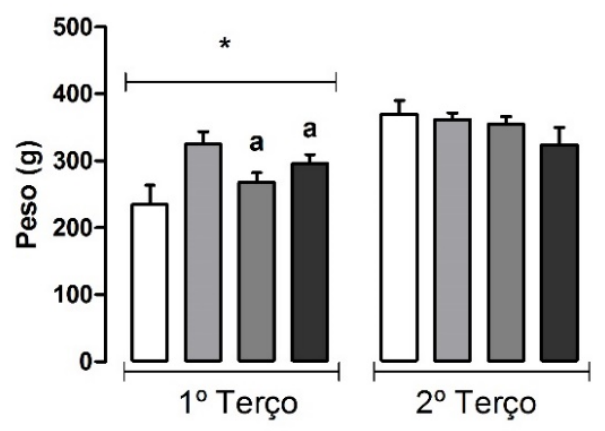

C

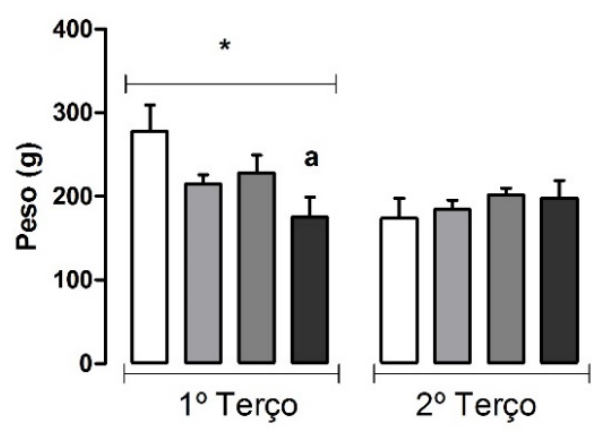


SS: tratamento durante a gestação com salina $0,9 \%$ e desafio no $5^{\circ}$ dia de lactação com salina $0,9 \%$; SM: tratamento durante a gestação com salina $0,9 \%$ e desafio no $5^{\circ}$ dia de lactação com $3,0 \mathrm{mg} / \mathrm{kg}$ de sulfato de morfina; MS: tratamento durante a gestação com $3,5 \mathrm{mg} / \mathrm{kg}$ de sulfato de morfina e desafio no $5^{\circ}$ dia de lactação com salina $0,9 \%$; MM: tratamento durante a gestação com $3,5 \mathrm{mg} / \mathrm{kg}$ de sulfato de morfina e desafio no $5^{\circ}$ dia de lactação com 3,0mg/kg de sulfato de morfina. Em (A), ganho de peso de ninhadas femininas mensuradas a partir do nascimento até os 21 dias de vida. ANOVA de duas vias p > 0,05. Em (B), ganho de peso de ninhadas femininas mensuradas aos 45 de vida. ANOVA de duas vias - diferenças significantes entre as fases de gestação e interação entre os fatores $\mathrm{p}<0,05$ seguida pelo teste de Bonferroni, $\mathbf{a}$ - diferenças significantes em relação ao grupo SS; * diferenças significantes entre as fases da gestação $p<0,05$. Em (C), ganho de peso de ninhadas femininas mensuradas aos 60 dias de vida. ANOVA de duas vias - diferenças significantes entre as fases de gestação e interação entre os fatores $\mathrm{p}<0,05$; seguida pelo teste de Bonferroni, $\mathbf{a}$ - diferença significante em relação ao grupo SS; * diferenças significantes entre as fases da gestação $p<0,05$. Os dados são apresentados como médias e erros-padrão ( $\mathrm{n}=10$ para todos os grupos). 
Figura 22 - Média do ganho de peso total das ninhadas femininas de ratas tratadas ou não com sulfato de morfina no primeiro ou segundo terços da gestação.

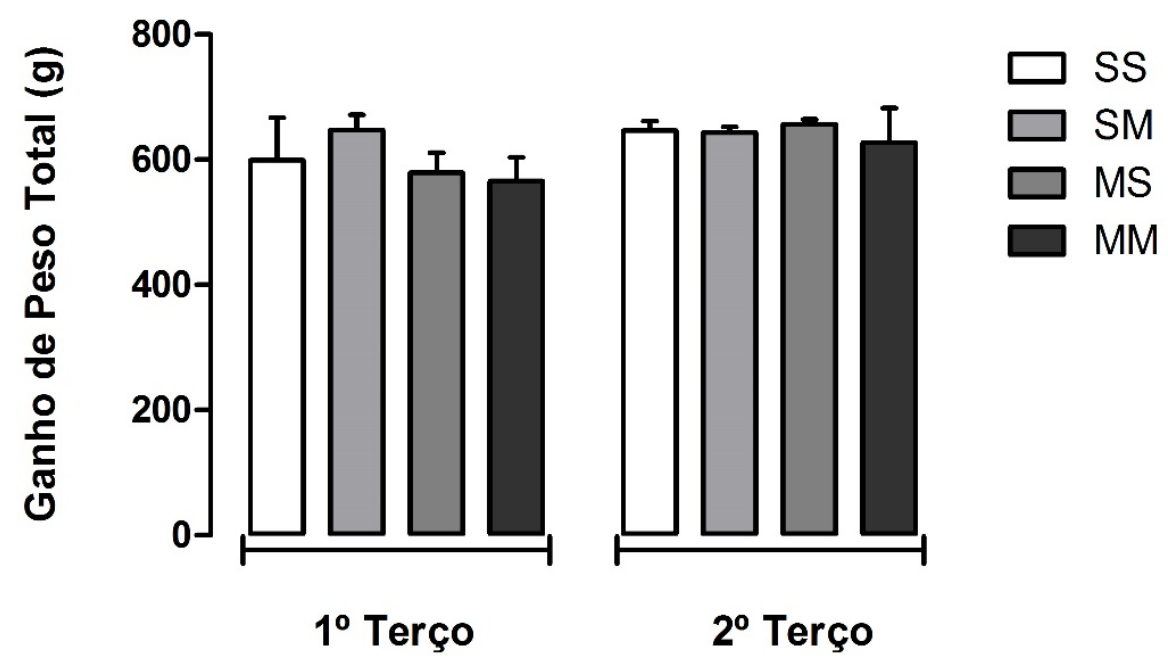

SS: tratamento durante a gestação com salina $0,9 \%$ e desafio no $5^{\circ}$ dia de lactação com salina $0,9 \%$; SM: tratamento durante a gestação com salina $0,9 \%$ e desafio no $5^{\circ}$ dia de lactação com $3,0 \mathrm{mg} / \mathrm{kg}$ de sulfato de morfina; MS: tratamento durante a gestação com $3,5 \mathrm{mg} / \mathrm{kg}$ de sulfato de morfina e desafio no $5^{\circ}$ dia de lactação com salina 0,9\%; MM: tratamento durante a gestação com 3,5mg/kg de sulfato de morfina e desafio no $5^{\circ}$ dia de lactação com 3,0mg/kg de sulfato de morfina. Os dados são apresentados como médias e erros-padrão ( $\mathrm{n}=10$ por grupo). ANOVA de duas vias, seguida de teste de Bonferroni $\mathrm{p}>0,05$. 
Figura 23 - Avaliação do ganho de peso das ninhadas masculinas de ratas tratadas ou não com sulfato de morfina no primeiro ou segundo terços da gestação.

A

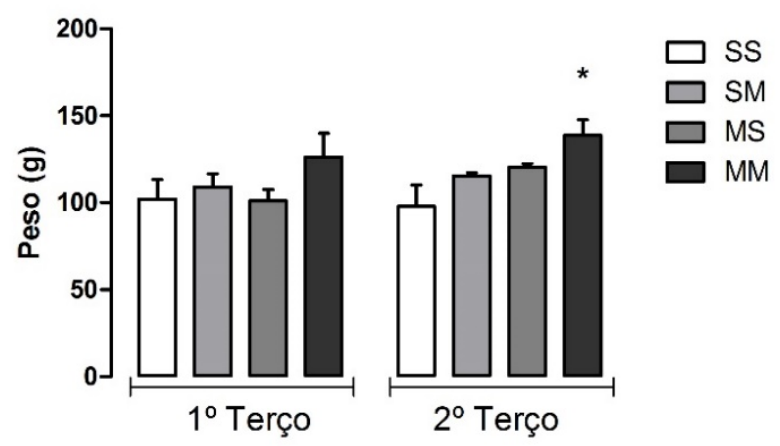

B

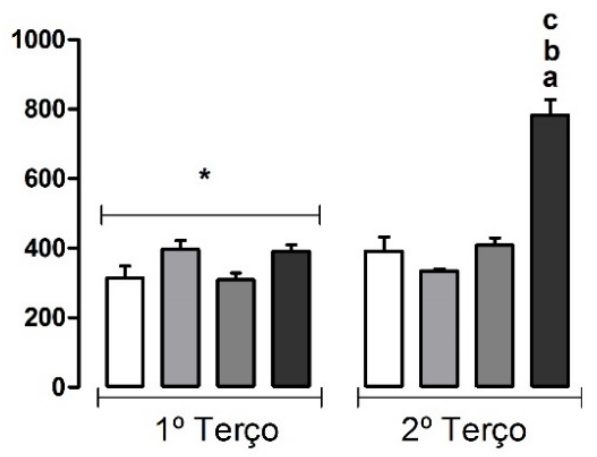

C

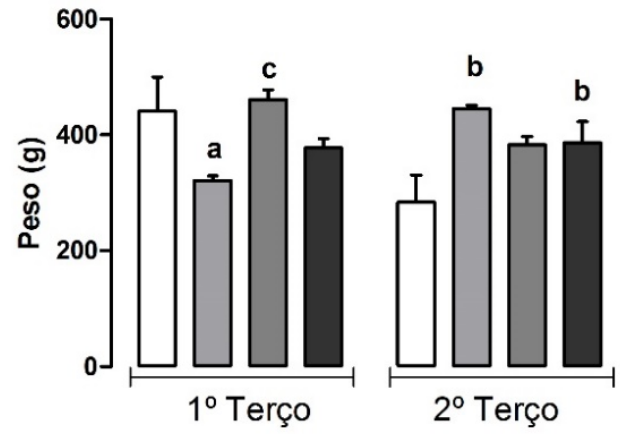


SS: tratamento durante a gestação com salina $0,9 \%$ e desafio no $5^{\circ}$ dia de lactação com salina $0,9 \%$; SM: tratamento durante a gestação com salina $0,9 \%$ e desafio no $5^{\circ}$ dia de lactação com $3,0 \mathrm{mg} / \mathrm{kg}$ de sulfato de morfina; MS: tratamento durante a gestação com $3,5 \mathrm{mg} / \mathrm{kg}$ de sulfato de morfina e desafio no $5^{\circ}$ dia de lactação com salina $0,9 \%$; MM: tratamento durante a gestação com $3,5 \mathrm{mg} / \mathrm{kg}$ de sulfato de morfina e desafio no $5^{\circ}$ dia de lactação com 3,0mg/kg de sulfato de morfina. Em (A), ganho de peso de ninhadas masculinas mensuradas a partir do nascimento até os 21 dias de vida. ANOVA de duas vias - diferença significante entre tratamentos $\mathrm{p}<$ 0,05 seguida pelo teste de Bonferroni; * diferença significantes comparado a SS no segundo terço da gestação. Em (B), ganho de peso de ninhadas masculinas mensuradas aos 45 dias de vida. ANOVA de duas vias diferença significantes entre os tratamentos, períodos de vida e com interação entre os fatores $p<0,01$, seguida do teste de Bonferroni; $\mathbf{a}$ - diferença significante comparado a SS; $\mathbf{b}$ - diferença significante comparado a SM e $\mathbf{c}$ diferença significante comparado a MS todos no segundo terço da gestação; * diferença significante entre as fases da gestação $\mathrm{p}<0,05$. Em (C), ganho de peso de ninhadas masculinas mensuradas aos 60 dias de vida. ANOVA de duas vias - diferença significantes entre os tratamentos, períodos de vida e com interação entre os fatores $\mathbf{p}<0,01$, seguida do teste de Bonferroni; $\mathbf{a}$ - diferença significante comparado a SS no primeiro terço da gestação; b - diferença significante comparado a SS no primeiro terço da gestação; $\mathbf{c}$ - diferença significante comparado a SM no segundo terço da gestação. Os dados são apresentados como médias e erros-padrão (n=10 por grupo). 
Figura 24 - Avaliação do ganho de peso total das ninhadas masculinas de ratas tratadas ou não com sulfato de morfina no primeiro ou segundo terços da gestação.

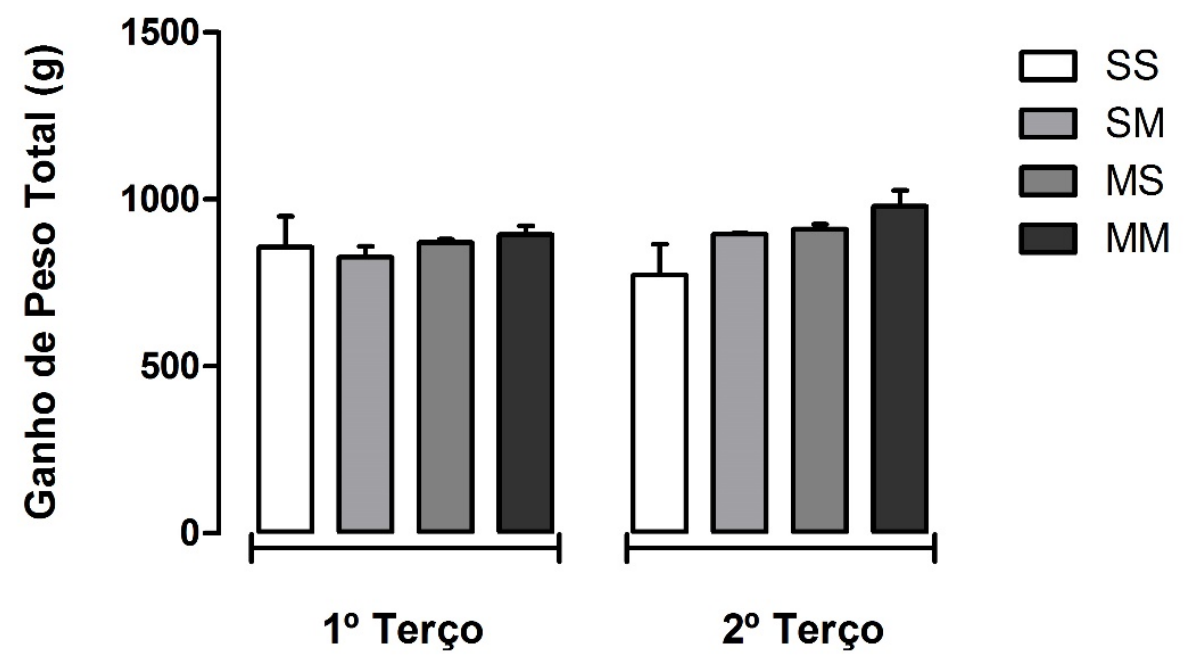

SS: tratamento durante a gestação com salina $0,9 \%$ e desafio no $5^{\circ}$ dia de lactação com salina $0,9 \%$; SM: tratamento durante a gestação com salina $0,9 \%$ e desafio no $5^{\circ}$ dia de lactação com $3,0 \mathrm{mg} / \mathrm{kg}$ de sulfato de morfina; MS: tratamento durante a gestação com $3,5 \mathrm{mg} / \mathrm{kg}$ de sulfato de morfina e desafio no $5^{\circ}$ dia de lactação com salina $0,9 \%$; MM: tratamento durante a gestação com $3,5 \mathrm{mg} / \mathrm{kg}$ de sulfato de morfina e desafio no $5^{\circ}$ dia de lactação com 3,0mg/kg de sulfato de morfina. Os dados são apresentados como médias e erros-padrão ( $\mathrm{n}=10$ por grupo). ANOVA de duas vias, seguida de teste de Bonferroni $\mathrm{p}>0,05$. 


\subsection{Experimento 3 - Avaliação do desenvolvimento físico das proles femininas e masculinas de ratas tratadas ou não com sulfato de morfina no primeiro ou segundo terços da gestação.}

\subsubsection{Delineamento Experimental}

No segundo dia após nascimento, as proles feminina e masculina de ratas tratadas ou não com sulfato de morfina no primeiro ou segundo terços da gestação tiveram suas distâncias ano-genitais mensuradas por meio de um paquímetro $(\mathrm{mm})$. Em relação à avaliação do desenvolvimento físico das proles, diariamente foram observados os seguintes parâmetros até o dia de ocorrência: aparecimento da penugem e pêlos, desdobramento das orelhas, erupção dos dentes incisivos, abertura do canal auditivo, abertura dos olhos, descida dos testículos, abertura da rima vaginal e andar adulto.

\subsubsection{Resultados}

A ANOVA de duas vias não indicou diferenças significantes quanto ao tratamento em relação à distância ano-genital (Figura $25 \mathrm{~A})\left[\mathrm{F}_{(3,72)}=0,73, \mathrm{p}=0,53\right]$ também não foram observadas diferenças significantes entre os períodos da gestação $\left[\mathrm{F}_{(1,72)}=0,66, \mathrm{p}=0,42\right]$, não houve interação entre os fatores $\left[\mathrm{F}_{(3,72)}=2,6, \mathrm{p}=0,06\right]$. O teste de Bonferroni não indicou diferenças significantes entre os diferentes grupos.

A ANOVA de duas vias não indicou diferenças significantes em relação ao dia de ocorrência do desdobramento das orelhas (Figura 25B) em relação ao tratamento $\left[\mathrm{F}_{(3,72)}=\right.$ $0,91, p=0,43]$ também não foram observadas diferenças significantes entre os períodos da gestação $\left[F_{(1,72)}=3,12, p=0,08\right]$, não foi observada interação entre os fatores $\left[F_{(3,72)}=2,8, p\right.$ $=0,05]$. O teste de Bonferroni não indicou diferenças significantes entre os diferentes grupos.

$\mathrm{Na}$ Figura 25C, que ilustra o dia de abertura dos olhos, a ANOVA de duas vias não indicou diferenças significantes quanto ao tratamento $\left[\mathrm{F}_{(3,72)}=1,28, \mathrm{p}=0,29\right]$. Porém foram observadas diferenças significantes entre os períodos da gestação $\left[F_{(1,72)}=9,72, p=0,002\right]$, e não houve interação entre os fatores $\left[\mathrm{F}_{(3,72)}=0,99, \mathrm{p}=0,40\right]$. O teste de Bonferroni não indicou diferenças significantes entre os diferentes grupos. 
$\mathrm{Na}$ Figura 25D, que mostra o dia de ocorrência do aparecimento da penugem, a ANOVA de duas vias não mostrou a existência de diferenças significantes entre os tratamentos $\left[\mathrm{F}_{(3,72)}=2,14, \mathrm{p}=0,10\right]$, nem foram observadas diferenças significantes entre os períodos da gestação $\left[\mathrm{F}_{(1,72)}=0, \mathrm{p}=1,00\right]$, não houve interação entre os fatores $\left[\mathrm{F}_{(3,72)}=0,83\right.$, $\mathrm{p}=0,50]$. O teste de Bonferroni não indicou diferenças significantes entre os diferentes grupos.

A ANOVA de duas vias não mostrou significância no parâmetro de aparecimento dos pêlos (Figura 25E) em relação aos diferentes tratamentos $\left[\mathrm{F}_{(3,72)}=1,6, \mathrm{p}=0,20\right]$, nem foram observadas diferenças significantes entre os períodos da gestação $\left[\mathrm{F}_{(1,72)}=1,92, \mathrm{p}=0,17\right]$, não foi observada interação entre os fatores $\left[\mathrm{F}_{(3,72)}=0,87, \mathrm{p}=0,45\right]$. O teste de Bonferroni não indicou diferenças significantes entre os diferentes grupos.

$\mathrm{Na}$ Figura 25F, ANOVA de duas vias não indicou existência de diferenças significantes entre os tratamentos sobre o parâmetro de erupção dos dentes incisivos $\left[\mathrm{F}_{(3,72)}=\right.$ $1,02, \mathrm{p}=0,4]$ nem foram observadas diferenças significantes entre os períodos da gestação $\left[F_{(1,72)}=0,7, p=0,40\right]$ foi observada interação entre os fatores $\left[F_{(3,72)}=2,75, p=0,05\right]$. O teste de Bonferroni não indicou diferenças significantes entre os diferentes grupos.

Na Figura 25G, a ANOVA de duas vias não mostrou a existência de diferenças significantes entre os tratamentos sobre o dia de ocorrência da abertura do canal auditivo $\left[\mathrm{F}_{(3,72)}=1,2 ; \mathrm{p}=0,31\right]$, não foram observadas diferenças significantes entre os períodos da gestação $\left[\mathrm{F}_{(1,72)}=3,4 \mathrm{p}=0,07\right]$, não houve interação entre os fatores $\left[\mathrm{F}_{(3,72)}=2,03, \mathrm{p}=0,12\right]$. $\mathrm{O}$ teste de Bonferroni não indicou diferenças significas entre os diferentes grupos.

A ANOVA de duas vias não mostrou significância no aparecimento dos pêlos (Figura $25 \mathrm{H})$ em relação aos diferentes tratamentos sobre o dia de ocorrência do andar adulto $\left[\mathrm{F}_{(3,72)}=\right.$ $0,08, p=0,97]$, porém foram observadas diferenças significantes entre os períodos da gestação $\left[F_{(1,72)}=4,22, p=0,04\right]$, não foi observada interação entre os fatores $\left[F_{(3,72)}=0,04, p\right.$ $=0,99]$. O teste de Bonferroni não indicou diferenças significantes entre os diferentes grupos.

Na Figura 25I, que ilustra o dia de ocorrência da abertura do canal vaginal, a ANOVA de duas vias indicou que o tratamento alterou os resultados $\left[\mathrm{F}_{(3,72)}=6,47 ; \mathrm{p}=0,0006\right]$ foram observadas diferenças significantes entre os períodos da gestação $\left[\mathrm{F}_{(1,72)}=8,90 ; \mathrm{p}=0,004\right]$ e houve interação entre os fatores $\left[\mathrm{F}_{(3,72)}=5,48 ; \mathrm{p}=0,002\right]$. O teste de Bonferroni indicou que as proles dos grupos SM, MS e MM apresentaram um atraso na abertura do canal vaginal comparados ao grupo SS no primeiro terço da gestação. 
Na Figura 26A, a ANOVA de duas vias não indicou diferenças significantes quanto ao tratamento sobre a distância ano-genital $\left[\mathrm{F}_{(3,72)}=0,007, \mathrm{p}=0,53\right]$ não foram observadas diferenças significantes entre os períodos da gestação $\left[\mathrm{F}_{(1,72)}=0,66, \mathrm{p}=0,42\right]$, não houve interação entre os fatores $\left[\mathrm{F}_{(3,72)}=2,6, \mathrm{p}=0,99\right]$. O teste de Bonferroni não indicou diferenças significantes entre os diferentes grupos.

A ANOVA de duas vias não indicou diferenças significantes em relação ao dia de ocorrência do desdobramento das orelhas (Figura 26B) quanto ao tratamento $\left[\mathrm{F}_{(3,72)}=0,03, \mathrm{p}\right.$ $=0,99]$ não foram observadas diferenças significantes entre os períodos da gestação $\left[\mathrm{F}_{(1,72)}=\right.$ $0,48, \mathrm{p}=0,48]$ e não foi observada interação entre os fatores $\left[\mathrm{F}_{(3,72)}=0,05, \mathrm{p}=0,98\right]$. O teste de Bonferroni não indicou diferenças significantes entre os diferentes grupos.

Na Figura 26C a ANOVA de duas vias não indicou diferenças significantes quanto ao tratamento em relação ao dia de ocorrência da abertura dos olhos $\left[\mathrm{F}_{(3,72)}=0,001, \mathrm{p}=1,0\right]$ não foram observadas diferenças significantes entre os períodos da gestação $\left[\mathrm{F}_{(1,72)}=0,05, \mathrm{p}=\right.$ $0,82]$, não havendo interação entre os fatores $\left[\mathrm{F}_{(3,72)}=0,00002, \mathrm{p}=1,0\right]$. O teste de Bonferroni não indicou diferenças significantes entre os diferentes grupos.

Na Figura 26D, a ANOVA de duas vias de duas vias não mostrou a existência de diferenças significantes entre os tratamentos sobre o aparecimento da penugem $\left[\mathrm{F}_{(3,72)}=0,03\right.$, $\mathrm{p}=0,99]$, não foram observadas diferenças significantes entre os períodos da gestação $\left[\mathrm{F}_{(1,72)}\right.$ $=0,03 \mathrm{p}=0,85]$, não houve interação entre os fatores $\left[\mathrm{F}_{(3,72)}=0,13, \mathrm{p}=0,99\right]$. O teste de Bonferroni não indicou diferenças significantes entre os diferentes grupos.

Em relação ao aparecimento de pêlos (Figura 26E), a ANOVA de duas vias não mostrou a existência de diferenças significantes entre os tratamentos $\left[\mathrm{F}_{(3,72)}=0,05, \mathrm{p}=0,98\right]$, não foram observadas diferenças significantes entre os períodos da gestação $\left[\mathrm{F}_{(1,72)}=0,07 \mathrm{p}=\right.$ $0,8]$, não foi observada interação entre os fatores $\left[\mathrm{F}_{(3,72)}=0,05, \mathrm{p}=0,98\right]$. O teste de Bonferroni não indicou diferenças significantes entre os diferentes grupos.

Na Figura 26F que ilustra a erupção dos dentes incisivos, a ANOVA de duas vias não mostrou a existência de diferenças significantes entre os tratamentos $\left[\mathrm{F}_{(3,72)}=0,01, \mathrm{p}=0,99\right]$, não foram observadas diferenças significantes entre os períodos da gestação $\left[\mathrm{F}_{(1,72)}=0,04 \mathrm{p}=\right.$ $0,83]$, não foi observada interação entre os fatores $\left[\mathrm{F}_{(3,72)}=0,03, \mathrm{p}=0,99\right]$. O teste de Bonferroni não indicou diferenças significantes entre os diferentes grupos.

Na Figura 26G, que mostra o dia de ocorrência da abertura do canal auditivo, a ANOVA de duas vias de duas vias não mostrou a existência de diferenças significantes entre os tratamentos $\left[\mathrm{F}_{(3,72)}=0,003 ; \mathrm{p}=0,99\right]$, não foram observadas diferenças significantes entre 
os períodos da gestação $\left[\mathrm{F}_{(1,72)}=0,02 ; \mathrm{p}=0,9\right]$, não houve interação entre os fatores $\left[\mathrm{F}_{(3,72)}=\right.$ $0,006, p=0,99]$. O teste de Bonferroni não indicou diferenças significantes entre os diferentes grupos.

A ANOVA de duas vias não mostrou a existência de diferenças significantes entre os tratamentos sobre o dia de ocorrência do andar adulto (Figura $26 \mathrm{H})\left[\mathrm{F}_{(3,72)}=0,006 ; p=0,99\right]$, não foram observadas diferenças significantes entre os períodos da gestação $\left[\mathrm{F}_{(1,72)}=0,02 ; \mathrm{p}\right.$ $=0,88]$, não foi observada interação entre os fatores $\left[\mathrm{F}_{(3,72)}=0,01, \mathrm{p}=0,99\right]$. O teste de Bonferroni não indicou diferenças significantes entre os diferentes grupos.

Na Figura 26I que mostra o dia de ocorrência da descida dos testículos, a ANOVA de duas vias não mostrou a existência de diferenças significantes entre os tratamentos $\left[\mathrm{F}_{(3,72)}=\right.$ $1,83, \mathrm{p}=0,15]$, não foram observadas diferenças significantes entre os períodos da gestação $\left[\mathrm{F}_{(1,72)}=1,52 \mathrm{p}=0,22\right]$, não houve interação entre os fatores $\left[\mathrm{F}_{(3,72)}=1,70, \mathrm{p}=0,17\right]$. O teste de Bonferroni indicou que:

1) as proles do grupo SM apresentaram um atraso para a descida dos testículos comparadas ao grupo SS no primeiro terço da gestação;

2) as proles dos grupos MS e MM também obtiveram um atraso no mesmo parâmetro comparados a SM e MS, respectivamente ambos no segundo terço da gestação. 
Figura 25 - Avaliação do desenvolvimento físico das ninhadas femininas de ratas tratadas ou não com sulfato de morfina no primeiro ou segundo terços da gestação.

A

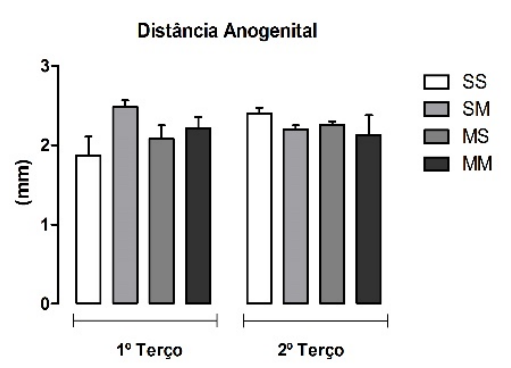

D

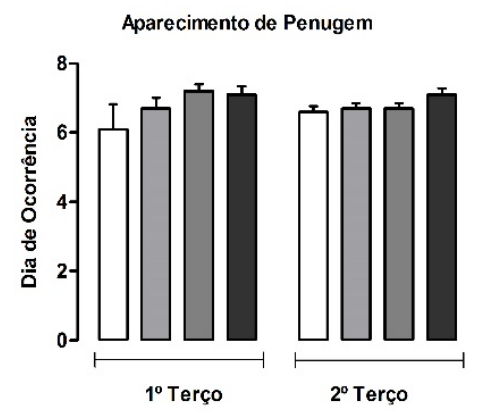

G

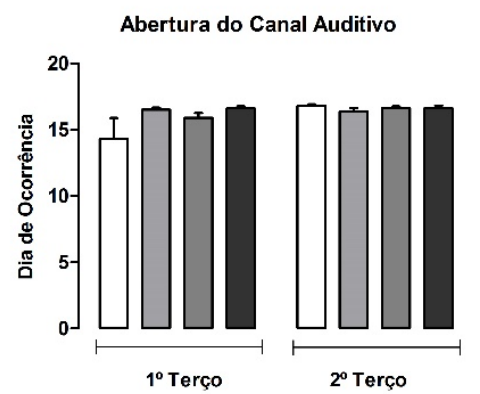

B
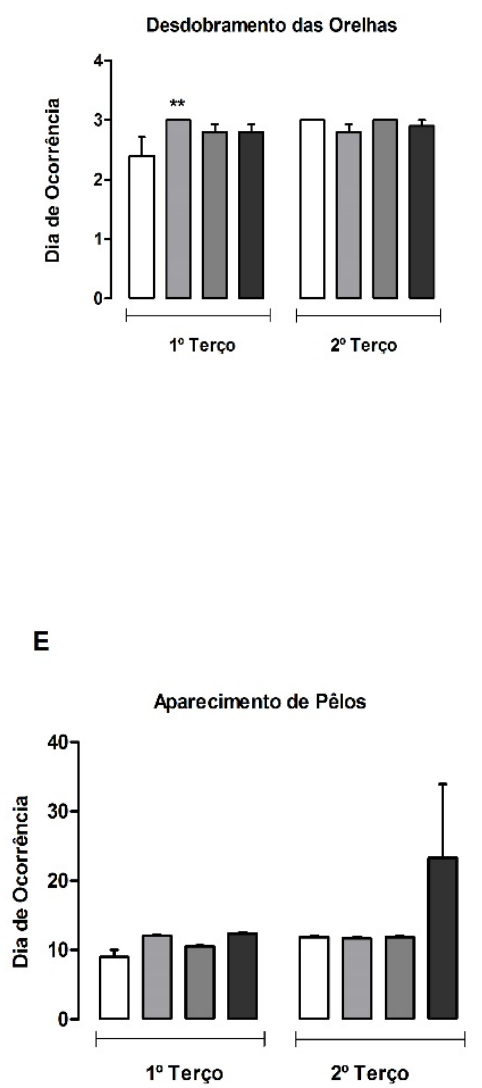

H

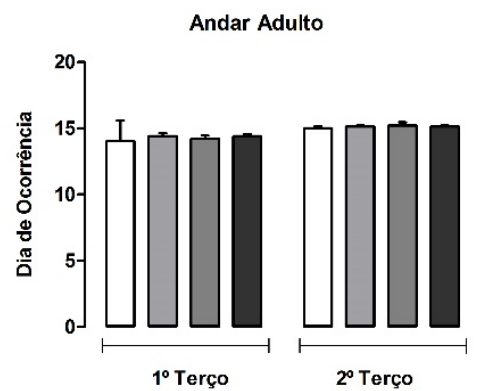

C

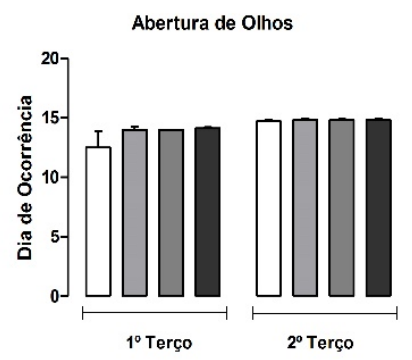

$\mathbf{F}$

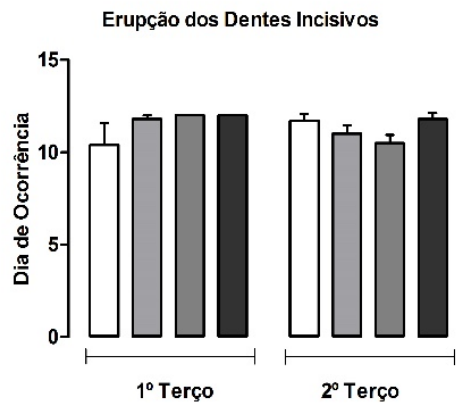

I

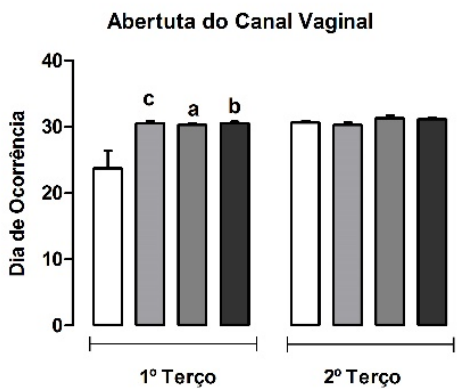


SS: tratamento durante a gestação com salina $0,9 \%$ e desafio no $5^{\circ}$ dia de lactação com salina $0,9 \%$; SM: tratamento durante a gestação com salina $0,9 \%$ e desafio no $5^{\circ}$ dia de lactação com $3,0 \mathrm{mg} / \mathrm{kg}$ de sulfato de morfina; MS: tratamento durante a gestação com $3,5 \mathrm{mg} / \mathrm{kg}$ de sulfato de morfina e desafio no $5^{\circ}$ dia de lactação com salina $0,9 \%$; MM: tratamento durante a gestação com $3,5 \mathrm{mg} / \mathrm{kg}$ de sulfato de morfina e desafio no $5^{\circ}$ dia de lactação com 3,0mg/kg de sulfato de morfina. Em (A), distância anogenital (mm) p >0,05; (B) dia de ocorrência do desdobramento das orelhas, $p>0,05$ e (C) dia de ocorrência da abertura dos olhos, $p>0,05$. Em (D) dia de ocorrência do aparecimento da penugem, $\mathrm{p}>0,05$; (E) dia de ocorrência do aparecimento dos pelos, $\mathrm{p}>0,05 \mathrm{e}$ (F) dia de ocorrência do aparecimento dos dentes incisivos, $p>0,05$. Em (G) dia de ocorrência da abertura do canal auditivo, $p>0,05$; (H) dia de ocorrência do andar adulto, $p>0,05$ e (I) dia de ocorrência da abertura do canal vaginal; ANOVA de duas - diferenças significantes entre os tratamentos, fases da gestação e interação entre os fatores $\mathrm{p}<0,05$, seguida pelo teste de Bonferroni, $\mathbf{a}-\mathrm{p}<0,001$ comparado a SS no primeiro terço da gestação; $\mathbf{b}-\mathbf{p}<0,001$ comparado a SS no primeiro terço da gestação; $\mathbf{c}-\mathbf{p}<0,001$ comparado a SS no primeiro terço da gestação. Os dados são apresentados como médias e erros-padrão ( $\mathrm{n}=10$ por grupo). ANOVA de duas vias, seguida de teste de Bonferroni $\mathrm{p}>0,05$. 
Figura 26 - Avaliação do desenvolvimento físico das ninhadas masculinas de ratas tratadas ou não com sulfato de morfina no primeiro ou segundo terços da gestação.

A

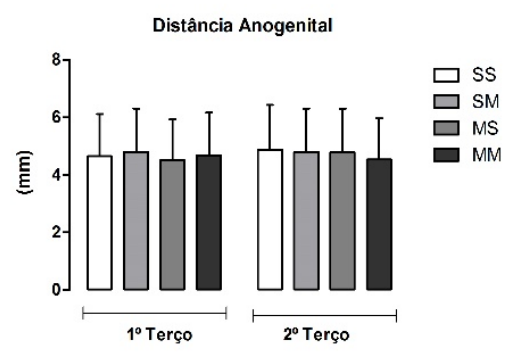

D

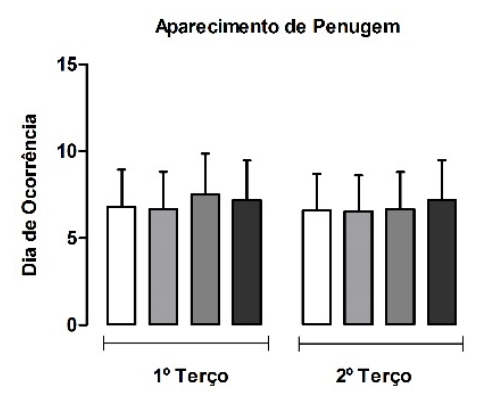

G

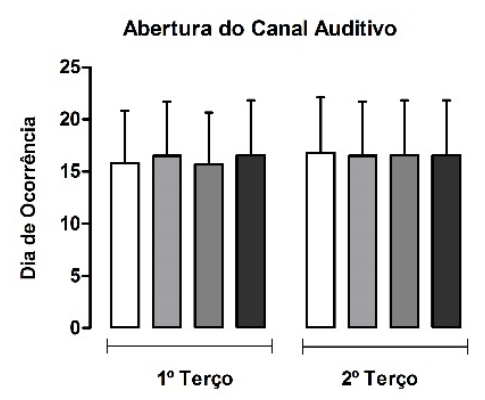

B

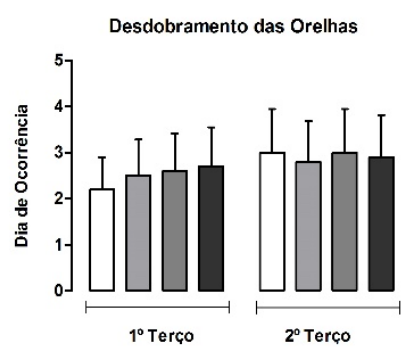

E
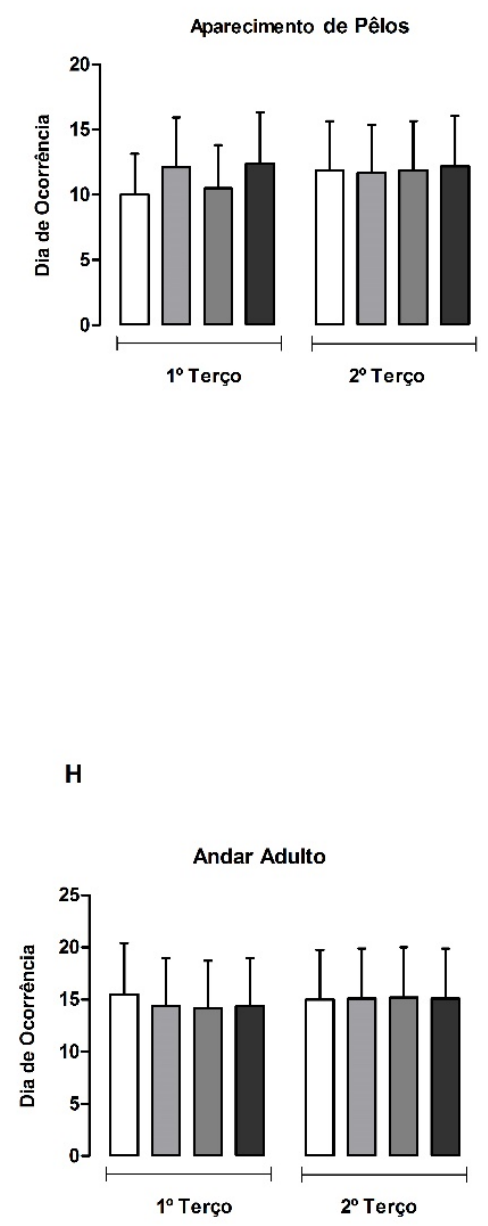

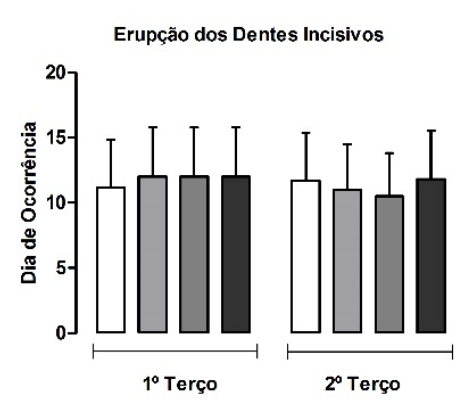

I

C

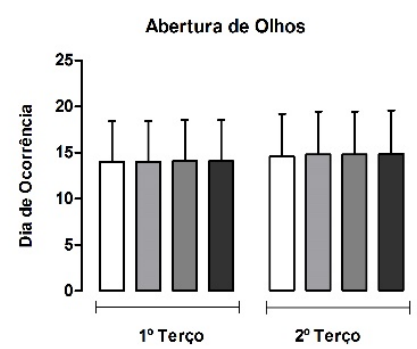

F

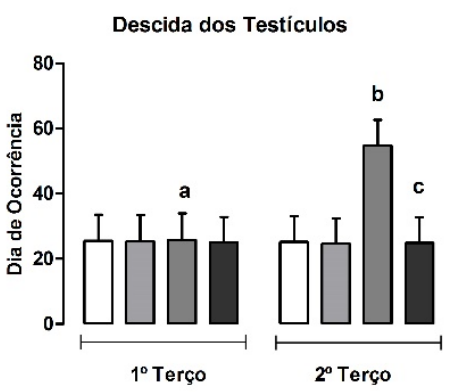


SS: tratamento durante a gestação com salina $0,9 \%$ e desafio no $5^{\circ}$ dia de lactação com salina $0,9 \%$; SM: tratamento durante a gestação com salina $0,9 \%$ e desafio no $5^{\circ}$ dia de lactação com $3,0 \mathrm{mg} / \mathrm{kg}$ de sulfato de morfina; MS: tratamento durante a gestação com $3,5 \mathrm{mg} / \mathrm{kg}$ de sulfato de morfina e desafio no $5^{\circ}$ dia de lactação com salina $0,9 \%$; MM: tratamento durante a gestação com $3,5 \mathrm{mg} / \mathrm{kg}$ de sulfato de morfina e desafio no $5^{\circ}$ dia de lactação com 3,0mg/kg de sulfato de morfina. Em (A), distância anogenital (mm), p > 0,05; (B) dia de ocorrência do desdobramento das orelhas, $p>0,05$ e (C) dia de ocorrência da abertura dos olhos, $p>0,05$. Em (D) dia de ocorrência do aparecimento da penugem, $p>0,05$; (E) dia de ocorrência do aparecimento dos pêlos, $p$ $>0,05$ e (F) dia de ocorrência do aparecimento dos dentes incisivos, $p>0,05$. Em (G) dia de ocorrência da abertura do canal auditivo, $p>0,05 ;(\mathrm{H})$ dia de ocorrência do andar adulto, $p>0,05$ e (I) dia de ocorrência da descida dos testículos; $\mathbf{a}$ - $\mathbf{p}<0,05$ comparado a SS no primeiro terço da gestação; $\mathbf{b}-\mathbf{p}<0,05$ comparado a SM no segundo terço da gestação; $\mathbf{c}-\mathrm{p}<0,05$ comparado a MS no segundo terço da gestação. Os dados são apresentados como médias e erros-padrão ( $\mathrm{n}=10$ por grupo). ANOVA de duas vias, seguida de teste de Bonferroni $\mathrm{p}>0,05$. 


\subsection{Experimento 4 - Avaliação do desenvolvimento neurocomportamental das proles femininas e masculinas de ratas tratadas ou não com sulfato de morfina no primeiro ou segundo terços da gestação.}

\subsubsection{Delineamento Experimental}

As proles masculina e feminina, logo ao nascimento, foram observadas quando a ocorrência dos parâmetros físicos (Experimento 3) e concomitantemente também quanto aos parâmetros de desenvolvimento neurocomportamental, sendo determinado (em dia de ocorrência) os reflexos de geotaxia negativa, endireitamento de postura e preensão palmar.

\subsubsection{Resultados}

A Figura 27 ilustra os parâmetros de reflexos de geotaxia negativa, endireitamento de postura e resposta de preensão palmar das proles femininas nos diferentes períodos de tratamento durante a gestação.

Na Figura 27A, que mostra reflexo de a geotaxia negativa, a ANOVA de duas vias não indicou diferenças significantes quanto ao tratamento $\left[\mathrm{F}_{(3,72)}=0,68, \mathrm{p}=0,57\right]$ também não indicou diferenças significantes entre os períodos da gestação $\left[\mathrm{F}_{(1,72)}=0,60 ; p=0,44\right]$, não foi observada interação entre os fatores $\left[\mathrm{F}_{(3,72)}=2,2, \mathrm{p}=0,09\right]$. O teste de Bonferroni não indicou diferenças significantes entre os diferentes grupos.

A ANOVA de duas vias não indicou diferenças significantes em relação ao reflexo de endireitamento da postura (Figura 27B) quanto ao tratamento $\left[\mathrm{F}_{(3,72)}=1,24, \mathrm{p}=0,30\right]$ porém foram observadas diferenças significantes entre os períodos da gestação $\left[\mathrm{F}_{(1,72)}=5,9, \mathrm{p}=\right.$ $0,02]$, não houve interação entre os fatores $\left[\mathrm{F}_{(3,72)}=0,8 ; \mathrm{p}=0,50\right]$. $\mathrm{O}$ teste de Bonferroni não indicou diferenças significantes entre os diferentes grupos.

Na Figura 27C a ANOVA de duas vias não indicou diferenças significantes quanto ao tratamento sobre a resposta de preensão palmar $\left[\mathrm{F}_{(3,72)}=2,30, \mathrm{p}=0,84\right]$. Porém foram observadas diferenças significantes entre os períodos da gestação $\left[\mathrm{F}_{(1,72)}=19,31, \mathrm{p}<0,0001\right]$, foi observada interação entre os fatores $\left[\mathrm{F}_{(3,72)}=3,9, \mathrm{p}=0,01\right]$. O teste de Bonferroni indicou que as proles dos grupos SM, MS e MM apresentaram um aumento na latência de geotaxia negativa em relação ao grupo SS e ao grupo SM, ambos no primeiro terço da gestação. 
A Figura 28 ilustra os parâmetros de geotaxia negativa, endireitamento da postura e resposta de preensão palmar das proles masculinas nos diferentes períodos de tratamento na gestação.

$\mathrm{Na}$ Figura 28A, que mostra a reflexo de geotaxia negativa, a ANOVA de duas vias indicou diferenças significantes quanto ao tratamento $\left[\mathrm{F}_{(3,72)}=3,9, \mathrm{p}=0,01\right]$. Porém não foram observadas diferenças significantes entre os períodos da gestação $\left[\mathrm{F}_{(1,72)}=2,4 ; \mathrm{p}=\right.$ $0,13]$, não houve interação entre os fatores $\left[\mathrm{F}_{(3,72)}=1,62, \mathrm{p}=0,2\right]$. $\mathrm{O}$ teste de Bonferroni indicou que as proles dos grupos SM e MM apresentaram um aumento na latência de geotaxia negativa em relação ao grupo SS e ao grupo SM, ambos no primeiro terço da gestação.

A ANOVA de duas vias não indicou diferenças significantes em relação ao reflexo de endireitamento da postura (Figura $28 \mathrm{~B}$ ) quanto ao tratamento $\left[\mathrm{F}_{(3,72)}=1,77, \mathrm{p}=0,16\right]$, não foram observadas diferenças significantes entre os períodos da gestação $\left[\mathrm{F}_{(1,72)}=, 070, \mathrm{p}=\right.$ $0,40]$, não houve interação entre os fatores $\left[\mathrm{F}_{(3,72)}=1,46 ; \mathrm{p}=0,23\right]$. O teste de Bonferroni indicou que as proles do grupo MS apresentaram um aumento na latência de endireitamento da postura, em relação ao grupo SS no primeiro terço da gestação.

Na Figura 28C a ANOVA de duas vias não indicou diferenças significantes quanto ao tratamento sobre a resposta de preensão palmar $\left[\mathrm{F}_{(3,72)}=0,06 ; \mathrm{p}=0,99\right]$, não foram observadas diferenças significantes entre os períodos da gestação $\left[\mathrm{F}_{(1,72)}=0,8 ; \mathrm{p}=0,38\right]$, não foi observada interação entre os fatores $\left[\mathrm{F}_{(3,72)}=0,03 \mathrm{p}=0,99\right]$. O teste de Bonferroni não indicou diferenças significantes entre os diferentes grupos. 
Figura 27 - Avaliação dos parâmetros do reflexo de geotaxia negativa, reflexo de endireitamento da postura e resposta de preensão palmar relacionados ao desenvolvimento físico das ninhadas femininas de ratas tratadas ou não com sulfato de morfina no primeiro ou segundo terços da gestação.

A Geotaxia Negativa

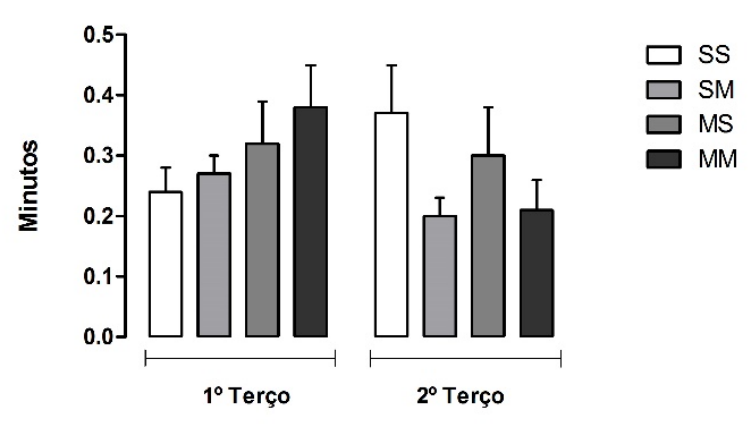

B

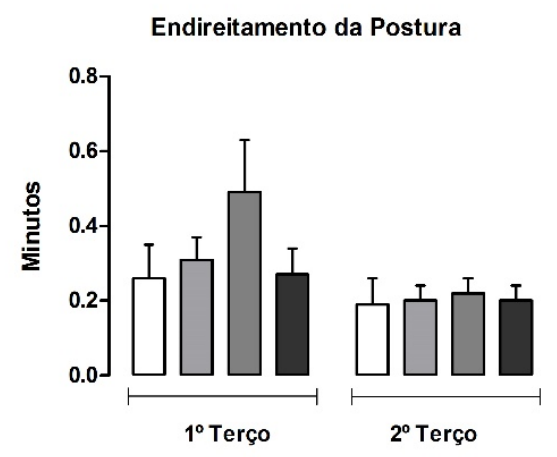

C

Resposta de Preensão Palmar

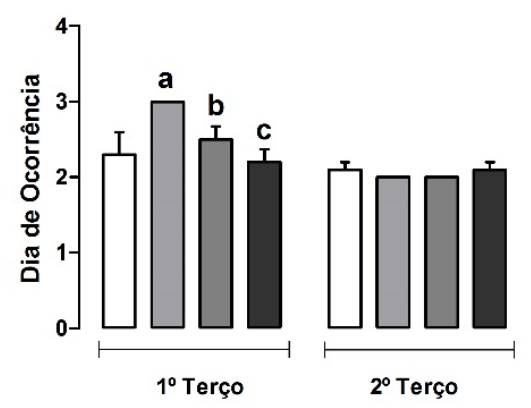


SS: tratamento durante a gestação com salina $0,9 \%$ e desafio no $5^{\circ}$ dia de lactação com salina $0,9 \%$; SM: tratamento durante a gestação com salina $0,9 \%$ e desafio no $5^{\circ}$ dia de lactação com $3,0 \mathrm{mg} / \mathrm{kg}$ de sulfato de morfina; MS: tratamento durante a gestação com $3,5 \mathrm{mg} / \mathrm{kg}$ de sulfato de morfina e desafio no $5^{\circ}$ dia de lactação com salina $0,9 \%$; MM: tratamento durante a gestação com $3,5 \mathrm{mg} / \mathrm{kg}$ de sulfato de morfina e desafio no $5^{\circ}$ dia de lactação com 3,0mg/kg de sulfato de morfina. Em (A), latência (s) a geotaxia negativa; (B) latência (s) ao endireitamento da postura e (C) dia de ocorrência da resposta de preensão palmar. a - $p<0,01$ comparado a SS no primeiro terço da gestação; $\mathbf{b}-\mathrm{p}<0,05$ comparado a SM no primeiro terço da gestação e $\mathbf{c}-\mathrm{p}<0,001$ comparado a SM no primeiro terço da gestação. Os dados são apresentados como médias e erros-padrão (n=10 por grupo). ANOVA de duas vias, seguida de teste de Bonferroni. 
Figura 28 - Avaliação dos parâmetros do reflexo de geotaxia negativa, endireitamento da postura e resposta de preensão palmar relacionados ao desenvolvimento físico das ninhadas masculinas de ratas tratadas ou não com sulfato de morfina no primeiro ou segundo terços da gestação.

A

Geotaxia Negativa

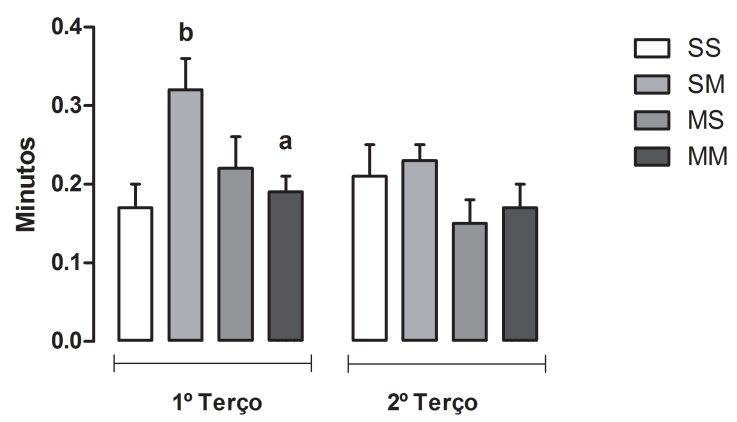

B

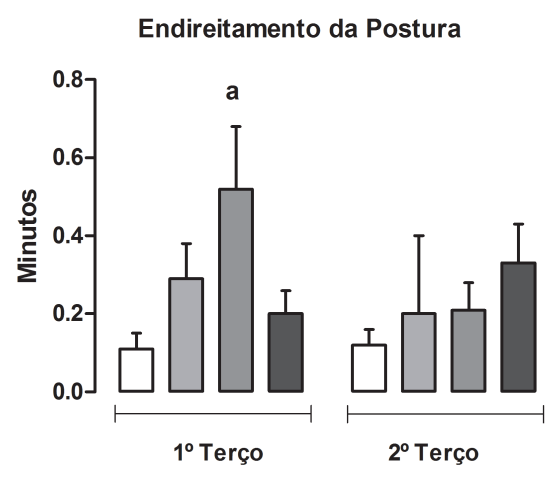

C

Resposta de Preensão Palmar

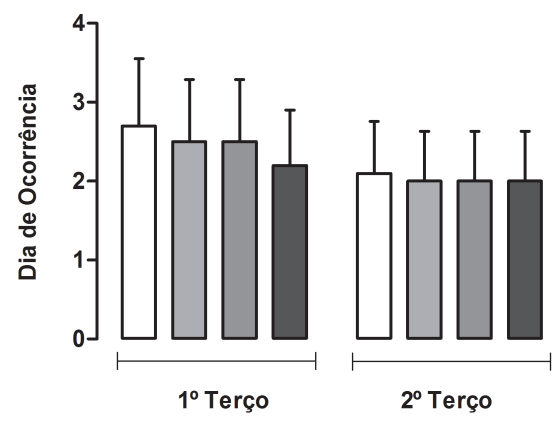


SS: tratamento durante a gestação com salina $0,9 \%$ e desafio no $5^{\circ}$ dia de lactação com salina $0,9 \%$; SM: tratamento durante a gestação com salina $0,9 \%$ e desafio no $5^{\circ}$ dia de lactação com $3,0 \mathrm{mg} / \mathrm{kg}$ de sulfato de morfina; MS: tratamento durante a gestação com $3,5 \mathrm{mg} / \mathrm{kg}$ de sulfato de morfina e desafio no $5^{\circ}$ dia de lactação com salina 0,9\%; MM: tratamento durante a gestação com 3,5mg/kg de sulfato de morfina e desafio no $5^{\circ}$ dia de lactação com 3,0mg/kg de sulfato de morfina. Em (A), latência (s) a geotaxia negativa; $\mathbf{a}-\mathrm{p}<0,05$ comparado a SM no primeiro terço da gestação; b - p $<0,01$ comparado a SS no primeiro terço da gestação; em (B) latência (s) ao endireitamento da postura, a - p $<0,05$ comparado a SS no primeiro terço da gestação e (C) dia de ocorrência da resposta de preensão palmar $\mathrm{p}>0,05$. Os dados são apresentados como médias e erros-padrão ( $\mathrm{n}=10$ por grupo). ANOVA de duas vias, seguida de teste de Bonferroni. 


\subsection{Experimento 5 - Análise da expressão de Oprk1, Oprm1 e Oprd1 que codificam para} os receptores opióides $\kappa, \mu$ e $\delta$ respectivamente, bem como os produtos protéicos KOR, MOR e DOR no estriado, hipotálamo e PAG de ratas bem como das proles femininas e masculinas

\subsubsection{Delineamento Experimental}

Foram utilizadas seis ratas por grupo formado de acordo com os Protocolos 1 e 2 previamente descritos no item 3.4. Materiais e Métodos. Para as análises moleculares nas mães tratadas ou não com sulfato de morfina no primeiro ou segundo terços da gestação, estas sofreram eutanásia por decapitação imediatamente após a avaliação do $\mathrm{CM}$, sendo seus encéfalos removidos e realizados os procedimentos de obtenção do RNA total, transcrição reversa e qPCR conforme item 3.9 de Materiais e Métodos. Para a análise dos produtos protéicos KOR, MOR e DOR os encéfalos foram removidos e realizados os procedimentos de obtenção de proteína total, quantificação protéica, eletroforese em gel de poliacrilaminda sob condições denaturantes, eletro-transferência das proteínas e imunodetecção das proteínas de interesse conforme item 3.10 de Materiais e Métodos. Outras mães, cujos grupos foram os mesmos descritos anteriormente, permaneceram com seus filhotes até o dia do desmame sendo depois descartadas. Os animais das proles feminina e masculina, e conforme o tratamento, foram avaliados quanto aos desenvolvimentos físico e neurocomportamental e sofreram eutanásia por decapitação e os encéfalos foram removidos para as análises moleculares conforme os itens 3.9 e 3.10 de Materiais e Métodos.

\subsubsection{Resultado $1-q P C R$ de receptores opióides e produtos portéicos nas mães}

A Figura 29 mostra a análise da expressão de Oprk1, Oprm1 e Oprd1 que codificam para os receptores opióides $\kappa, \mu$ e $\delta$ respectivamente, bem como os produtos protéicos KOR, MOR e DOR no estriado de mães tratadas ou não com sulfato de morfina no primeiro ou segundo terços da gestação.

A Figura 29A mostra a expressão de Oprk1 no estriado de mães, a ANOVA de duas vias mostrou que houve diferenças significantes entre os tratamentos $\left[\mathrm{F}_{(3,40)}=10,92, \mathrm{p}<\right.$ $0,0001]$, foram observadas diferenças significantes entre os períodos da gestação $\left[\mathrm{F}_{(1,40)}=\right.$ $11,68, p=0,001]$ bem como observou-se interação entre os fatores $\left[F_{(3,40)}=2,87, p=0,05\right]$. $O$ teste de Bonferroni indicou que: 
1) As mães dos grupos SM e MM apresentaram um aumento na expressão de Oprk1 em relação ao grupo SS em ambos os terços da gestação;

2) As mães do grupo MS apresentaram um diminuição na expressão de Oprk1 em relação ao grupo SM no primeiro terço da gestação;

3) As mães do grupo MM apresentaram um aumento na expressão de Oprk1 em relação ao grupo SM no segundo terço da gestação;

4) As mães do grupo MM apresentaram um aumento na expressão de Oprk1 em relação ao grupo MS em ambos os terços da gestação;

Em relação ao produto protéico $\mathrm{KOR} / \alpha$-tubulina no estriado de mães, a ANOVA de duas vias mostrou que houve diferenças significantes entre os tratamentos $\left[\mathrm{F}_{(3,40)}=245,8, \mathrm{p}<\right.$ 0,0001], observou-se também diferenças significantes entres os períodos da gestação $\left[\mathrm{F}_{(1,40)}=\right.$ $208,0, p<0,0001]$ foi observada interação entre os fatores $\left[\mathrm{F}_{(3,40)}=158,7, \mathrm{p}<0,0001\right]$. O teste de Bonferroni mostrou que:

1) As mães do grupo SM apresentaram uma diminuição de KOR/ $\alpha$-tubulina no estriado em relação ao grupo SS no segundo terço da gestação;

2) As mães dos grupos MS e MM apresentaram um aumento de $\mathrm{KOR} / \boldsymbol{\alpha}$-tubulina no estriado em relação ao grupo SS no primeiro terço da gestação;

3) As mães do grupo MS apresentaram um aumento de KOR/ $\alpha$-tubulina no estriado em relação ao grupo SM no segundo terço da gestação;

4) As mães do grupo $\mathrm{MM}$ apresentaram um aumento de $\mathrm{KOR} / \alpha$-tubulina no estriado em relação ao grupo SM em ambos os terços da gestação;

5) As mães do grupo MM apresentaram um aumento de KOR/ $\alpha$-tubulina no estriado em relação ao grupo MS no primeiro terço da gestação.

A Figura 29B mostra a análise da expressão de Oprm1 no estriado de mães, a ANOVA de duas vias mostrou que houve diferenças significantes entre os tratamentos $\left[F_{(3,40)}=6,68, p\right.$ $=0,0009]$, não observou-se diferenças significantes entre os períodos da gestação $\left[F_{(1,40)}=\right.$ $0,14, p=0,71]$ e nem interação entre os fatores $\left[F_{(3,40)}=5,09, p=0,004\right]$. O teste de Bonferroni indicou que:

1) As mães dos grupos SM, MS e MM apresentaram um aumento na expressão de Oprm1 em relação aos grupos SS em ambos os terços da gestação; 
2) As mães do grupo MS apresentaram um aumento na expressão de Oprm1 em relação ao grupo SM no primeiro terço da gestação;

3) As mães do grupo MM apresentaram uma diminuição na expressão de $O p r m 1 \mathrm{em}$ relação aos grupos SM e MS no primeiro terço da gestação.

Sobre o produto protéico MOR/ $\alpha$-tubulina no estriado de mães, a ANOVA de duas vias mostrou que houve diferenças significantes entre os tratamentos $\left[F_{(3,40)}=4,64, p=0,007\right]$, observou-se também diferenças significantes entres os períodos da gestação $\left[\mathrm{F}_{(1,40)}=88,41, \mathrm{p}\right.$ $=0,004]$ foi observada interação entre os fatores $\left[\mathrm{F}_{(3,40)}=5,07, \mathrm{p}<0,0001\right]$. O teste de Bonferroni mostrou que as mães dos grupos MS e MM apresentaram uma diminuição de MOR/ $\alpha$-tubulina no estriado em relação aos grupos SS e SM no segundo terço da gestação.

A Figura 29C mostra a análise da expressão de Oprd1, no estriado de mães, a ANOVA de duas vias não mostrou diferenças significantes entre os tratamentos $\left[\mathrm{F}_{(3,40)}=0,04\right.$, $\mathrm{p}=0,99]$, não observou-se diferenças significantes entre os períodos da gestação $\left[\mathrm{F}_{(1,40)}=\right.$ $0,06, p=0,81]$, tampouco houve interação entre os fatores $\left[F_{(3,40)}=0,02, p=0,99\right]$. O teste de Bonferroni não indicou diferenças significantes entre os diferentes grupos.

Sobre o produto protéico DOR/ $\alpha$-tubulina no estriado de mães, a A ANOVA de duas vias mostrou que houve diferenças significantes entre os tratamentos $\left[\mathrm{F}_{(3,40)}=6,75, \mathrm{p}=\right.$ $0,0009]$, observou-se também diferenças significantes entres os períodos da gestação $\left[\mathrm{F}_{(1,40)}=\right.$ $36,80, p<0,0001]$ foi observada interação entre os fatores $\left[F_{(3,40)}=3,32, p=0,029\right]$. O teste de Bonferroni mostrou que:

1) As mães do grupo MS apresentaram uma diminuição de $\mathrm{DOR} / \alpha$-tubulina no estriado em relação aos grupos SS e SM no segundo terço da gestação;

2) As mães do grupo MM apresentaram um aumento de DOR/ $\alpha$-tubulina no estriado em relação ao grupo MS no segundo terço da gestação.

A Figura 30 mostra a análise da expressão de Oprk1, Oprm1 e Oprd1 que codificam para os receptores opióides $\kappa, \mu$ e $\delta$ respectivamente, bem como os produtos protéicos KOR, MOR e DOR no hipotálamo de mães tratadas ou não com sulfato de morfina no primeiro ou segundo terços da gestação.

A Figura 30A mostra a análise da expressão de Oprk1 no hipotálamo de mães, a ANOVA de duas vias não mostrou diferenças significantes entre os tratamentos $\left[\mathrm{F}_{(3,33)}=\right.$ 
0,002, $\mathrm{p}=0,99]$, não foram obsevrvadas diferenças significantes entre os períodos da gestação $\left[F_{(1,33)}=0,29, p=0,59\right]$ bem como não observou-se interação entre os fatores $\left[\mathrm{F}_{(3,22)}=0,004, \mathrm{p}=0,99\right]$. O teste de Bonferroni não indicou diferenças significantes entre os diferentes grupos.

Em relação ao produto protéico KOR/ $\alpha$-tubulina no hipotálamo de mães, a ANOVA de duas vias mostrou que houve diferenças significantes entre os tratamentos $\left[\mathrm{F}_{(3,40)}=7,12, \mathrm{p}\right.$ $=0,0006]$, observou-se também diferenças significantes entres os períodos da gestação $\left[\mathrm{F}_{(1,40)}\right.$ $=115,4, p<0,0001]$ foi observada interação entre os fatores $\left[F_{(3,40)}=6,22, p=0,0014\right]$. $O$ teste de Bonferroni mostrou que:

1) As mães do grupo MS apresentaram uma diminuição de $\mathrm{KOR} / \alpha$-tubulina no hipotálamo em relação ao grupo SS no segundo terço da gestação;

2) As mães do grupo $\mathrm{MM}$ apresentaram um aumento de $\mathrm{KOR} / \boldsymbol{\alpha}$-tubulina no hipotálamo em relação a SS em ambos os terços da gestação e SM e MS no primeiro terço da gestação.

A Figura 30B mostra a análise da expressão de Oprm1 no hipotálamo de mães, a ANOVA de duas vias mostrou que houve diferenças significantes entre os tratamentos $\left[\mathrm{F}_{(3,40)}\right.$ $=6,04, \mathrm{p}=0,0017]$, foram observadas diferenças significantes entre os períodos da gestação $\left[F_{(1,40)}=40,80, p<0,0001\right]$ bem como interação entre os fatores $\left[F_{(3,40)}=6,90, p=0,0007\right] . O$ teste de Bonferroni indicou que:

1) As mães dos grupos SM e MS apresentaram um aumento na expressão de Oprm1 em relação ao grupo SS no primeiro terço da gestação;

2) As mães do grupo $\mathrm{MM}$ apresentaram uma diminuição na expressão do gene Oprm1 em relação aos grupos SM e MS no primeiro terço da gestação.

Sobre o produto protéico MOR/ $\alpha$-tubulina no hipotálamo de mães, a ANOVA de duas vias mostrou que houve diferenças significantes entre os tratamentos $\left[F_{(3,40)}=4,83, p=\right.$ 0,006], observou-se também diferenças significantes entres os períodos da gestação $\left[\mathrm{F}_{(1,40)}=\right.$ $34,0, p<0,0001]$ foi observada interação entre os fatores $\left[F_{(3,40)}=7,30, p=0,0005\right]$. O teste de Bonferroni mostrou que:

1) As mães dos grupos MS e MM apresentaram um aumento de MOR/ $\alpha$-tubulina no hipotálamo em relação ao grupo SS no segundo terço da gestação;

2) As mães do grupo $\mathrm{MM}$ apresentaram um aumento de $\mathrm{MOR} / \alpha$-tubulina no hipotálamo em relação ao grupo SM no segundo terço da gestação; 
3) As mães do grupo MM apresentaram uma diminuição de $\mathrm{MOR} / \alpha$-tubulina no hipotálamo em relação ao grupo MS no primeiro terço da gestação;

A Figura 30C mostra a análise da expressão de $\operatorname{Oprd1}$, no hipotálamo de mães, a ANOVA de duas vias não mostrou diferenças significantes entre os tratamentos $\left[\mathrm{F}_{(3,40)}=0,21\right.$, $\mathrm{p}=0,88]$, não observou-se diferenças significantes entre os períodos da gestação $\left[\mathrm{F}_{(1,40)}=\right.$ $0,74, p=0,39]$ e não houveinteração entre os fatores $\left[F_{(3,40)}=0,11, p=0,95\right]$. O teste de Bonferroni não indicou diferenças significantes entre os diferentes grupos.

Em relação ao produto protéico DOR/ $\alpha$-tubulina no hipotálamo de mães, a ANOVA de duas vias não mostrou diferenças significantes entre os tratamentos $\left[\mathrm{F}_{(3,40)}=0,75, \mathrm{p}=\right.$ $0,53]$, porém observou-se diferenças significantes entres os períodos da gestação $\left[\mathrm{F}_{(1,40)}=\right.$ $45,06, p<0,0001]$ e foi observada interação entre os fatores $\left[F_{(3,40)}=3,04, p=0,04\right]$. O teste de Bonferroni mostrou que as mães do grupo MM apresentaram uma diminuição de DOR/ $\alpha$ tubulina no hipotálamo em relação ao grupo MS no primeiro terço da gestação.

A Figura 31 mostra a análise da expressão de Oprk1, Oprm1 e Oprd1 que codificam para os receptores opióides $\kappa, \mu$ e $\delta$ respectivamente, bem como os produtos protéicos KOR, MOR e DOR na PAG de mães tratadas ou não com sulfato de morfina no primeiro ou segundo terços da gestação.

A Figura 31A mostra a análise da expressão de Oprk1, na PAG de mães, a ANOVA de duas vias não mostrou diferenças significantes entre os tratamentos $\left[\mathrm{F}_{(3,40)}=1,28, \mathrm{p}=0,29\right]$, não observou-se diferenças significantes entre os períodos da gestação $\left[\mathrm{F}_{(1,40)}=1,15, \mathrm{p}=\right.$ $0,29]$, bem como interação entre os fatores $\left[\mathrm{F}_{(3,40)}=1,30, \mathrm{p}=0,28\right]$. O teste de Bonferroni indicou que as mães do grupo SM apresentaram um aumento na expressão de Oprk1 em relação ao grupo SS no primeiro terço da gestação.

Sobre o produto protéico KOR/ $\alpha$-tubulina na PAG. A ANOVA de duas vias mostrou que houve diferenças significantes entre os tratamentos $\left[\mathrm{F}_{(3,40)}=3,79, \mathrm{p}=0,017\right]$, observou-se também diferenças significantes entres os períodos da gestação $\left[\mathrm{F}_{(1,40)}=292,9, \mathrm{p}<0,0001\right]$ foi observada interação entre os fatores $\left[F_{(3,40)}=54,66, p<0,0001\right]$. O teste de Bonferroni mostrou que:

1) As mães do grupos MS apresentaram uma diminuição de $\mathrm{KOR} / \alpha$-tubulina na $\mathrm{PAG}$ em relação ao grupo SS no primeiro terço da gestação; 
2) As mães do grupo $\mathrm{MM}$ apresentaram um aumento de $\mathrm{KOR} / \alpha$-tubulina na $\mathrm{PAG}$ no primeiro terço da gestação e uma diminuição do mesmo produto protéico no segundo terço da gestação, ambos em relação aos grupos SS, SM e MS;

3) As mães do grupo MS apresentaram uma diminuição de KOR/ $\alpha$-tubulina na PAG em relação aos grupo SM no primeiro terço da gestação.

A Figura 31B mostra a análise da expressão de Oprm1 na PAG de mães, a ANOVA de duas vias mostrou que os tratamentos alteraram os resultados $\left[\mathrm{F}_{(3,40)}=3,53, \mathrm{p}=0,02\right]$, foram observadas diferenças significantes entre os períodos da gestação $\left[\mathrm{F}_{(1,40)}=6,48, \mathrm{p}=0,01\right]$ com interação entre os fatores $\left[\mathrm{F}_{(3,40)}=10,82, \mathrm{p}<0,0001\right]$. O teste de Bonferroni indicou que:

1) As mães do grupo SM apresentaram um aumento na expressão de Oprml em relação ao grupo SS no primeiro terço da gestação;

2) As mães dos grupos MS e MM apresentaram uma diminuição na expressão de Oprm1 em relação ao grupo SM também no primeiro terço da gestação.

Sobre o produto protéico MOR/ $\alpha$-tubulina na PAG de mães, a ANOVA de duas vias mostrou que houve diferenças significantes entre os tratamentos $\left[F_{(3,40)}=11,44, p<0,0001\right]$, observou-se também diferenças significantes entres os períodos da gestação $\left[F_{(1,40)}=85,43, p\right.$ $<0,0001]$ foi observada interação entre os fatores $\left[\mathrm{F}_{(3,40)}=4,95, \mathrm{p}=0,005\right]$. O teste de Bonferroni mostrou que:

1) As mães do grupo SM apresentaram uma diminuição de $\mathrm{MOR} / \alpha$-tubulina na $\mathrm{PAG}$ em relação ao grupo SS no primeiro terço da gestação;

2) As mães dos grupos MS e MM apresentaram uma diminuição de MOR/ $\alpha$-tubulina na PAG em relação ao grupo SS em ambos os terços da gestação;

3) As mães dos grupos MS e MM apresentaram uma diminuição de MOR/ $\alpha$-tubulina na PAG em relação ao grupo SM no segundo terço da gestação;

A Figura 31C mostra a análise da expressão de Oprd1 na PAG de mães, a ANOVA de duas vias não mostrou diferenças significantes entre os tratamentos $\left[\mathrm{F}_{(3,40)}=0,33, \mathrm{p}=0,79\right]$, não observou-se diferenças significantes entre os períodos da gestação $\left[\mathrm{F}_{(1,40)}=0,001, \mathrm{p}=\right.$ $0,97]$ e não houve interação entre os fatores $\left[\mathrm{F}_{(3,40)}=0,34, \mathrm{p}=0,99\right]$. O teste de Bonferroni não indicou diferenças significantes entre os diferentes grupos.

Sobre o produto protéico DOR/ $\alpha$-tubulina na PAG de mães, a ANOVA de duas vias mostrou que houve diferenças significantes entre os tratamentos $\left[\mathrm{F}_{(3,40)}=7,64, \mathrm{p}=0,0004\right]$, 
observou-se também diferenças significantes entres os períodos da gestação $\left[\mathrm{F}_{(1,40)}=12,55, \mathrm{p}\right.$ $=0,001]$ foi observada interação entre os fatores $\left[\mathrm{F}_{(3,40)}=3,42, \mathrm{p}=0,026\right]$. O teste de Bonferroni mostrou que as mães dos grupos SM, MS e MM apresentaram uma diminuição de DOR/a-tubulina na PAG em relação ao grupo SS no primeiro terço da gestação.

\subsubsection{Resultado 2 - qPCR de receptores opióides e produtos protéicos nas proles femininas}

A Figura 32 mostra a análise da expressão de Oprk1, Oprm1 e Oprd1 que codificam para os receptores opióides $\kappa, \mu$ e $\delta$ respectivamente, bem como os produtos protéicos KOR, MOR e DOR no estriado das proles femininas de mães tratadas ou não com sulfato de morfina no primeiro ou segundo terços da gestação.

A Figura 32A mostra a análise da expressão de Oprk1 no estriado das proles femininas, a ANOVA de duas vias mostrou que houve diferenças significantes entre os tratamentos $\left[\mathrm{F}_{(3,40)}\right.$ $=4,15, \mathrm{p}=0,01]$, foram observadas diferenças significantes entre os períodos da gestação $\left[F_{(1,40)}=15,77, p=0,0003\right]$ bem como observou-se interação entre os fatores $\left[F_{(3,40)}=3,48, p\right.$ $=0,24]$. O teste de Bonferroni indicou que as proles do grupo MM apresentaram um aumento na expressão de Oprk1 em relação aos grupos SS e MS no segundo terço da gestação.

Em relação ao produto protéico $\mathrm{KOR} / \boldsymbol{\alpha}$-tubulina no estriado das proles femininas, a ANOVA de duas vias mostrou que houve diferenças significantes entre os tratamentos $\left[\mathrm{F}_{(3,40)}\right.$ $=3,98, \mathrm{p}=0,014]$, observou-se também diferenças significantes entres os períodos da gestação $\left[\mathrm{F}_{(1,40)}=49,01, \mathrm{p}<0,0001\right]$ porém não foi observada interação entre os fatores $\left[\mathrm{F}_{(3,40)}=1,36, \mathrm{p}=0,27\right]$. O teste de Bonferroni mostrou que as proles dos grupos SM e MS apresentaram um aumento de $\mathrm{KOR} / \boldsymbol{\alpha}$-tubulina no estriado em relação ao grupo SS no segundo terço da gestação.

A Figura 32B mostra a análise da expressão de Oprml no estriado das proles femininas, a ANOVA de duas vias não mostrou diferenças significantes entre os tratamentos $\left[\mathrm{F}_{(3,40)}=1,13, \mathrm{p}=0,35\right]$, não observou-se diferenças significantes entre os períodos da gestação $\left[\mathrm{F}_{(1,40)}=1,83, \mathrm{p}=0,18\right]$ e não houve interação entre os fatores $\left[\mathrm{F}_{(3,40)}=0,15, \mathrm{p}=\right.$ 0,92]. O teste de Bonferroni não indicou diferenças significantes entre os diferentes grupos.

Sobre o produto protéico $\mathrm{MOR} / \alpha$-tubulina no estriado das proles femininas, a ANOVA de duas vias não mostrou diferenças significantes entre os tratamentos $\left[\mathrm{F}_{(3,40)}=2,10\right.$, 
$\mathrm{p}=0,11]$, porém houve diferenças significantes entre os períodos da gestação $\left[\mathrm{F}_{(1,40)}=49,99\right.$, $\mathrm{p}<0,0001]$ e não foi observada interação entre os fatores $\left[\mathrm{F}_{(3,40)}=0,74, \mathrm{p}=0,53\right]$. O teste de Bonferroni mostrou que as proles do grupo MM apresentaram um aumento de MOR/ $\alpha$ tubulina no estriado em relação ao grupo SS no primeiro terço da gestação.

A Figura 32C mostra a análise da expressão de Oprd1 no estriado das proles femininas, a ANOVA de duas vias não mostrou diferenças significantes entre os tratamentos $\left[\mathrm{F}_{(3,40)}=0,18, \mathrm{p}=0,91\right]$, porém observou-se diferenças significantes entre os períodos da gestação $\left[\mathrm{F}_{(1,40)}=15,18, \mathrm{p}=0,0004\right]$ mas sem interação entre os fatores $\left[\mathrm{F}_{(3,40)}=0,42, \mathrm{p}=\right.$ 0,74]. O teste de Bonferroni não indicou diferenças significantes entre os diferentes grupos.

Sobre o produto protéico DOR/ $\alpha$-tubulina no estriado das proles femininas, a ANOVA de duas vias não mostrou diferenças significantes entre os tratamentos $\left[\mathrm{F}_{(3,40)}=0,08, \mathrm{p}=\right.$ 0,96], também não foram observadas diferenças significantes entre os períodos da gestação $\left[\mathrm{F}_{(1,40)}=1,12, \mathrm{p}=0,29\right]$ e não foi observada interação entre os fatores $\left[\mathrm{F}_{(3,40)}=0,26, \mathrm{p}=0,8\right]$. O teste de Bonferroni não mostrou diferenças entre os diferentes grupos.

A Figura 33 mostra a análise da expressão de Oprk1, Oprm1 e Oprd1 que codificam para os receptores opióides $\kappa, \mu$ e $\delta$ respectivamente, bem como os produtos protéicos KOR, MOR e DOR no hipotálamo das proles femininas de mães tratadas ou não com sulfato de morfina no primeiro ou segundo terços da gestação.

A Figura 33A mostra a análise da expressão de Oprk1 no hipotálamo das proles femininas. A ANOVA de duas vias não mostrou diferenças significantes entre os tratamentos $\left[\mathrm{F}_{(3,40)}=0,44, \mathrm{p}=0,72\right]$, não observou-se diferenças significantes entre os períodos da gestação $\left[\mathrm{F}_{(1,40)}=0,27, \mathrm{p}=0,60\right]$ bem como não observou-se interação entre os fatores $\left[\mathrm{F}_{(3,40)}\right.$ $=0,40, p=0,75]$. O teste de Bonferroni não indicou diferenças significantes entre os diferentes grupos.

Sobre o produto protéico $\mathrm{KOR} / \alpha$-tubulina no hipotálamo das proles femininas. A ANOVA de duas vias mostrou que houve diferenças significantes entre os tratamentos $\left[\mathrm{F}_{(3,40)}\right.$ $=18,12, \mathrm{p}<0,0001]$, observou-se também diferenças significantes entres os períodos da gestação $\left[F_{(1,40)}=3806, p<0,0001\right]$, foi observada interação entre os fatores $\left[F_{(3,40)}=26,74, p\right.$ $<0,0001]$. O teste de Bonferroni indicou que as proles do grupo MM apresentaram uma diminuição de $\mathrm{KOR} / \alpha$-tubulina no hipotálamo em relação aos grupos SS, SM e MS no segundo terço da gestação. 
A Figura 33B mostra a análise da expressão de Oprm1 no hipotálamo das proles femininas. A ANOVA de duas vias não mostrou diferenças significantes entre os tratamentos $\left[\mathrm{F}_{(3,40)}=0,37, \mathrm{p}=0,77\right]$, não observou-se diferenças significantes entre os períodos da gestação $\left[F_{(1,40)}=2,44, p=0,12\right]$, nem interação entre os fatores $\left[F_{(3,40)}=0,46, p=0,70\right]$. $O$ teste de Bonferroni não indicou diferenças significantes entre os diferentes grupos.

Em relação ao produto protéico MOR/ $\alpha$-tubulina no hipotálamo das proles femininas. A ANOVA de duas vias mostrou que houve diferenças significantes entre os tratamentos $\left[\mathrm{F}_{(3,40)}=5,09, \mathrm{p}=0,004\right]$, observou-se também diferenças significantes entres os períodos da gestação $\left[F_{(1,40)}=936,9, p<0,0001\right]$, foi observada interação entre os fatores $\left[F_{(3,40)}=21,35\right.$, $\mathrm{p}<0,0001]$. O teste de Bonferroni indicou que:

1) As proles do grupo SM apresentaram uma diminuição de $\mathrm{MOR} / \alpha$-tubulina no hipotálamo em relação ao grupo SS no segundo terço da gestação;

2) As proles dos grupos MS e MM apresentaram uma diminuição de $\mathrm{MOR} / \alpha$-tubulina no hipotálamo em relação ao grupo SM no primeiro terço da gestação;

3) As proles dos grupos MS e MM apresentaram um aumento de MOR/ $\alpha$-tubulina no hipotálamo em relação ao grupo SM no segundo terço da gestação;

A Figura 33C mostra a análise da expressão de Oprd1 no hipotálamo das proles femininas. A ANOVA de duas vias não mostrou diferenças significantes entre os tratamentos $\left[\mathrm{F}_{(3,40)}=0,15, \mathrm{p}=0,93\right]$, não observou-se diferenças significantes entre os períodos da gestação $\left[\mathrm{F}_{(1,40)}=0,06, \mathrm{p}=0,81\right]$ e também não observou-se interação entre os fatores $\left[\mathrm{F}_{(3,40)}=\right.$ $0,44, p=0,72]$. O teste de Bonferroni não indicou diferenças significantes entre os diferentes grupos.

Sobre o produto protéico DOR/ $\alpha$-tubulina no hipotálamo das proles femininas, a ANOVA de duas vias não mostrou diferenças significantes entre os tratamentos $\left[\mathrm{F}_{(3,40)}=0,98\right.$, $\mathrm{p}=0,41]$, porém foram observadas diferenças significantes entre os períodos da gestação $\left[\mathrm{F}_{(1,40)}=88,45, \mathrm{p}<0,0001\right]$ e não foi observada interação entre os fatores $\left[\mathrm{F}_{(3,40)}=0,39, \mathrm{p}=\right.$ 0,75]. O teste de Bonferroni não mostrou diferenças entre os diferentes grupos.

A Figura 34 mostra a análise da expressão de Oprk1, Oprm1 e Oprd1 que codificam para os receptores opióides $\kappa, \mu$ e $\delta$ respectivamente, bem como os produtos protéicos KOR, MOR 
e DOR na PAG das proles femininas de mães tratadas ou não com sulfato de morfina no primeiro ou segundo terços da gestação.

A Figura 34A mostra a análise da expressão de Oprk1 na PAG das proles femininas. A ANOVA de duas vias mostrou que houve diferenças significantes entre os tratamentos $\left[\mathrm{F}_{(3,40)}=7,48, \mathrm{p}=0,0004\right]$, observou-se diferenças significantes entre os períodos da gestação $\left[F_{(1,40)}=7,75, p=0,008\right]$ bem como houve interação entre os fatores $\left[F_{(3,40)}=4,41, p=\right.$ 0,009]. O teste de Bonferroni indicou que:

1) As proles dos grupos SM e MM apresentaram um aumento na expressão de Oprk1 em relação ao grupo SS no segundo terço da gestação;

2) As proles do grupo MS apresentaram uma diminuição na expressão de Oprk1 em relação ao grupo SM no segundo terço da gestação;

3) As proles do grupo MM apresentaram um aumento na expressão de Oprk1 em relação ao grupo MS no segundo terço da gestação.

Sobre o produto protéico KOR/ $\alpha$-tubulina na PAG das proles femininas a ANOVA de duas vias mostrou que houve diferenças significantes entre os tratamentos $\left[\mathrm{F}_{(3,40)}=19,00, \mathrm{p}<\right.$ 0,0001], observou-se também diferenças significantes entres os períodos da gestação $\left[\mathrm{F}_{(1,40)}=\right.$ 2313, $\mathrm{p}<0,0001]$ e foi observada interação entre os fatores $\left[\mathrm{F}_{(3,40)}=15,32, \mathrm{p}<0,0001\right]$. $\mathrm{O}$ teste de Bonferroni mostrou que as proles dos grupos MS e MM apresentaram um aumento de KOR/a-tubulina na PAG em relação aos grupos SS e SM no primeiro terço da gestação.

A Figura 34B mostra a análise da expressão de Oprm1 na PAG das proles femininas. A ANOVA de duas vias não mostrou diferenças significantes entre os tratamentos $\left[\mathrm{F}_{(3,40)}=\right.$ $1,84, p=0,15]$, não observou-se diferenças significantes entre os períodos da gestação $\left[\mathrm{F}_{(1,40)}\right.$ $=0,55, \mathrm{p}=0,46]$ e também não houve interação entre os fatores $\left[\mathrm{F}_{(3,40)}=2,76, \mathrm{p}=0,05\right]$. $\mathrm{O}$ teste de Bonferroni que:

1) As proles do grupo MS apresentaram uma diminuição expressão de Oprm1 em relação ao grupo SM no segundo terço da gestação;

2) As proles do grupo MM apresentaram um aumento expressão de Oprm1 em relação ao grupo MS no segundo terço da gestação.

Sobre o produto protéico MOR/ $\alpha$-tubulina na PAG das proles femininas, a ANOVA de duas vias mostrou que houve diferenças significantes entre os tratamentos $\left[\mathrm{F}_{(3,40)}=464,8, \mathrm{p}<\right.$ $0,0001]$, observou-se também diferenças significantes entres os períodos da gestação $\left[\mathrm{F}_{(1,40)}=\right.$ 
$78,98, \mathrm{p}<0,0001]$ e foi observada interação entre os fatores $\left[\mathrm{F}_{(3,40)}=848,1, \mathrm{p}<0,0001\right]$. O teste de Bonferroni mostrou que:

1) As proles do grupo $\mathrm{SM}$ apresentaram um diminuição de $\mathrm{MOR} / \alpha$-tubulina na $\mathrm{PAG}$ em relação aos grupo SS no primeiro terço da gestação;

2) As proles do grupo MS apresentaram um diminuição de $\mathrm{MOR} / \alpha$-tubulina na $\mathrm{PAG}$ em relação aos grupo SS no segundo terço da gestação;

3) As proles do grupo MS apresentaram um aumento de MOR/ $\alpha$-tubulina na PAG no primeiro terço da gestação e uma diminuição do mesmo produto protéico no segundo terço, ambos em relação aos grupo SM;

4) As proles do grupo MM apresentaram um aumento de MOR/ $\alpha$-tubulina na PAG em relação ao grupo SM no primeiro terço da gestação e em relação ao grupo MS no segundo terço da gestação.

A Figura 34C mostra a análise da expressão de Oprd1 na PAG das proles femininas. A ANOVA de duas vias não mostrou diferenças significantes entre os tratamentos $\left[\mathrm{F}_{(3,40)}=0,24\right.$, $\mathrm{p}=0,86]$, não observou-se diferenças significantes entre os períodos da gestação $\left[\mathrm{F}_{(1,40)}=\right.$ $0,06, p=0,80]$ e não houve interação entre os fatores $\left[F_{(3,40)}=0,59, p=0,62\right]$. O teste de Bonferroni não indicou diferenças significantes entre os diferentes grupos.

Sobre o produto protéico DOR/ $\alpha$-tubulina na PAG das proles femininas, a ANOVA de duas vias mostrou que não houve diferenças significantes entre os tratamentos $\left[\mathrm{F}_{(3,40)}=2,09\right.$, $\mathrm{p}=0,11]$, porém mostrou diferenças significantes entres os períodos da gestação $\left[\mathrm{F}_{(1,40)}=\right.$ $523,9, p<0,0001]$ e não foi observada interação entre os fatores $\left[F_{(3,40)}=2,79, p=0,05\right]$. $O$ teste de Bonferroni mostrou que:

1) As proles do grupo MS apresentaram uma diminuição de $D O R / \alpha$-tubulina na $P A G$ em relação ao grupo SS no primeiro terço da gestação;

2) As proles do grupo MM apresentaram um aumento de $D O R / \alpha$-tubulina na PAG em relação ao grupo MS no primeiro terço da gestação.

\subsubsection{Resultado 3 - qPCR de receptores opióides e produtos protéicos nas proles masculinas}

A Figura 35 mostra a análise da expressão de Oprk1, Oprm1 e Oprd1 que codificam para os receptores opióides $\kappa, \mu$ e $\delta$ respectivamente, bem como os produtos protéicos KOR, MOR 
e DOR no estriado das proles masculinas de mães tratadas ou não com sulfato de morfina no primeiro ou segundo terços da gestação.

A Figura 35A mostra a análise da expressão de Oprk1 no estriado das proles masculinas. A ANOVA de duas vias não mostrou diferenças significantes entre os tratamentos $\left[\mathrm{F}_{(3,40)}=0,23, \mathrm{p}=0,87\right]$, não observou-se diferenças significantes entre os períodos da gestação $\left[\mathrm{F}_{(1,40)}=0,0005, \mathrm{p}=0,98\right]$ e não houve interação entre os fatores $\left[\mathrm{F}_{(3,40)}=\right.$ $0,37, p=0,77]$. O teste de Bonferroni não indicou diferenças significantes entre os diferentes grupos.

Sobre o produto protéico KOR/ $\alpha$-tubulina no estriado das proles masculinas. A ANOVA de duas vias mostrou que houve diferenças significantes entre os tratamentos $\left[\mathrm{F}_{(3,40)}\right.$ $=22,47, \mathrm{p}<0,0001]$, observou-se também diferenças significantes entres os períodos da gestação $\left[F_{(1,40)}=3594, p<0,0001\right]$ e foi observada interação entre os fatores $\left[F_{(3,40)}=24,90\right.$, $\mathrm{p}<0,0001]$. O teste de Bonferroni mostrou que:

1) As proles dos grupos MS e MM apresentaram uma diminuição de KOR/ $\alpha$-tubulina no estriado em relação aos grupos SS e SM no primeiro terço da gestação;

2) As proles do grupo $\mathrm{MM}$ apresentaram uma diminuição de $\mathrm{KOR} / \alpha$-tubulina no estriado em relação ao grupo MS no primeiro terço da gestação.

A Figura 35B mostra a análise da expressão de Oprm1 no estriado das proles masculinas. A ANOVA de duas vias mostrou diferenças significantes entre os tratamentos $\left[\mathrm{F}_{(3,40)}=4,19, \mathrm{p}=0,01\right]$, não observou-se diferenças significantes entre os períodos da gestação $\left[\mathrm{F}_{(1,40)}=0,0001, \mathrm{p}=0,99\right]$ bem como não houve interação entre os fatores $\left[\mathrm{F}_{(3,40)}=\right.$ $3,93, \mathrm{p}=0,01]$. O teste de Bonferroni indicou que:

1) As proles do grupo SM apresentaram uma diminuição na expressão de $O p r m 1 \mathrm{em}$ relação ao grupo SS no segundo terço da gestação;

2) As proles do grupo MM apresentaram um aumento na expressão de Oprm1 em relação aos grupos SM e MS no segundo terço da gestação.

Sobre o produto protéico MOR/ $\alpha$-tubulina no estriado das proles masculinas. A ANOVA de duas vias mostrou que houve diferenças significantes entre os tratamentos $\left[\mathrm{F}_{(3,40)} 4,05, \mathrm{p}=\right.$ $0,013]$, observou-se também diferenças significantes entres os períodos da gestação $\left[\mathrm{F}_{(1,40)}=\right.$ $1450, p<0,0001]$ e foi observada interação entre os fatores $\left[F_{(3,40)}=3,28, p=0,030\right]$. O teste 
de Bonferroni mostrou que as proles do grupo MM apresentaram uma diminuição de $\mathrm{MOR} / \alpha-$ tubulina no estriado em relação aos grupos SS e SM no primeiro terço da gestação.

A Figura 35C mostra a análise da expressão de Oprdl no estriado das proles masculinas. A ANOVA de duas vias não mostrou diferenças significantes entre os tratamentos $\left[\mathrm{F}_{(3,40)}=0,07, \mathrm{p}=0,97\right]$, não observou-se diferenças significantes entre os períodos da gestação $\left[\mathrm{F}_{(1,40)}=0,41, \mathrm{p}=0,52\right]$ e não houve interação entre os fatores $\left[\mathrm{F}_{(3,40)}=\right.$ $0,04, p=0,98]$. O teste de Bonferroni não indicou diferenças significantes entre os diferentes grupos.

Sobre o produto protéico DOR/ $\alpha$-tubulina no estriado das proles masculinas. A ANOVA de duas vias mostrou que houve diferenças significantes entre os tratamentos $\left[\mathrm{F}_{(3,40)}\right.$ 26,73, $\mathrm{p}<0,0001]$, observou-se também diferenças significantes entres os períodos da gestação $\left[F_{(1,40)}=1030, p<0,0001\right]$ e foi observada interação entre os fatores $\left[F_{(3,40)}=5,54, p\right.$ $=0,003]$. O teste de Bonferroni mostrou que:

1) As proles do grupo $\mathrm{SM}$ apresentaram um aumento de $\mathrm{DOR} / \alpha$-tubulina no estriado em relação ao grupo SS no segundo terço da gestação;

2) As proles dos grupos MS e MM apresentaram uma diminuição de DOR/ $\alpha$-tubulina no estriado em relação ao grupo SS no segundo terço da gestação;

3) As proles dos grupos MS e MM apresentaram uma diminuição de DOR/ $\alpha$-tubulina no estriado em relação ao grupo SM em ambos os terços da gestação.

A Figura 36 mostra a análise da expressão de Oprk1, Oprm1 e Oprd1 que codificam para os receptores opióides $\kappa, \mu$ e $\delta$ respectivamente, bem como os produtos protéicos KOR, MOR e DOR no hipotálamo das proles masculinas de mães tratadas ou não com sulfato de morfina no primeiro ou segundo terços da gestação.

A Figura 36A mostra a análise da expressão de Oprk1 no hipotálamo das proles masculinas. A ANOVA de duas vias não mostrou diferenças significantes entre os tratamentos $\left[\mathrm{F}_{(3,40)}=1,45, \mathrm{p}=0,24\right]$, não observou-se diferenças significantes entre os períodos da gestação $\left[\mathrm{F}_{(1,40)}=0,11, \mathrm{p}=0,74\right]$ e não houve interação entre os fatores $\left[\mathrm{F}_{(3,40)}=\right.$ $0,20, \mathrm{p}=0,10]$. O teste de Bonferroni indicou que as proles do grupo MM apresentaram um aumento na expressão de Oprkl em relação aos grupos SS e SM no segundo terço da gestação. 
Sobre o produto protéico KOR/ $\alpha$-tubulina no hipotálamo das proles masculinas. A ANOVA de duas vias mostrou que houve diferenças significantes entre os tratamentos $\left[\mathrm{F}_{(3,40)}\right.$ $=22,87, \mathrm{p}<0,0001]$, observou-se também diferenças significantes entres os períodos da gestação $\left[F_{(1,40)}=150,3, p<0,0001\right]$ e foi observada interação entre os fatores $\left[F_{(3,40)}=30,95\right.$, $\mathrm{p}<0,0001]$. O teste de Bonferroni mostrou que:

1) As proles do grupo $\mathrm{SM}$ apresentaram uma diminuição de $\mathrm{KOR} / \boldsymbol{\alpha}$-tubulina no hipotálamo em relação aos grupo SS no primeiro terço da gestação;

2) As proles do grupo MS apresentaram um aumento de KOR/ $\alpha$-tubulina no hipotálamo em relação aos grupo SS no primeiro terço da gestação;

3) As proles dos grupos MS e MM apresentaram um aumento de KOR/ $\alpha$-tubulina no hipotálamo em relação aos grupo SM no primeiro terço da gestação.

A Figura 36B mostra a análise da expressão de Oprm1 no hipotálamo de proles masculinas. A ANOVA de duas vias não indicou diferenças significantes entre os tratamentos $\left[\mathrm{F}_{(3,40)}=2,01, \mathrm{p}=0,13\right]$, porém observou-se diferenças significantes entre os períodos da gestação $\left[\mathrm{F}_{(1,40)}=13,95, \mathrm{p}=0,0006\right]$, não houve interação entre os fatores $\left[\mathrm{F}_{(3,40)}=1,58, \mathrm{p}=\right.$ 0,21]. O teste de Bonferroni indicou que:

1) As proles do grupo MS apresentaram uma diminuição na expressão de $O p r m 1 \mathrm{em}$ relação aos grupos SS e SM no segundo terço da gestação;

2) As proles do grupo MM apresentaram um aumento na expressão de Oprm1 em relação ao grupo MS no segundo terço da gestação.

Sobre o produto protéico MOR/ $\alpha$-tubulina no hipotálamo das proles masculinas. A ANOVA de duas vias mostrou que houve diferenças significantes entre os tratamentos $\left[\mathrm{F}_{(3,40)}\right.$ $=10,63, \mathrm{p}<0,0001]$, observou-se também diferenças significantes entres os períodos da gestação $\left[\mathrm{F}_{(1,40)}=53,52, \mathrm{p}<0,0001\right]$ e foi observada interação entre os fatores $\left[\mathrm{F}_{(3,40)}=8,38\right.$, $\mathrm{p}=0,0002]$. O teste de Bonferroni mostrou que:

1) As proles dos grupos MS e MM apresentaram uma diminuição de KOR/ $\alpha$-tubulina no hipotálamo em relação ao grupo SS no segundo terço da gestação;

2) As proles do grupo MS apresentaram uma diminuição de $\mathrm{KOR} / \boldsymbol{\alpha}$-tubulina no hipotálamo em relação ao grupo SM no segundo terço da gestação;

3) As proles do grupo MM apresentaram um aumento de KOR/ $\alpha$-tubulina no hipotálamo em relação ao grupo MS no segundo terço da gestação; 
A Figura 36C mostra a análise da expressão de Oprd1 no hipotálamo das proles masculinas. A ANOVA de duas vias não mostrou diferenças significantes entre os tratamentos $\left[\mathrm{F}_{(3,40)}=0,02, \mathrm{p}=0,99\right]$, não observou-se diferenças significantes entre os períodos da gestação $\left[\mathrm{F}_{(1,40)}=0,11, \mathrm{p}=0,74\right]$ e não houve interação entre os fatores $\left[\mathrm{F}_{(3,40)}=\right.$ $0,02, p=0,99]$. O teste de Bonferroni não indicou diferenças significantes entre os diferentes grupos.

Sobre o produto protéico DOR/ $\alpha$-tubulina no hipotálamo das proles masculinas. A ANOVA de duas vias mostrou que houve diferenças significantes entre os tratamentos $\left[\mathrm{F}_{(3,40)}\right.$ $=10,52, \mathrm{p}<0,0001]$, observou-se também diferenças significantes entres os períodos da gestação $\left[F_{(1,40)}=19,98, p<0,0001\right]$ e foi observada interação entre os fatores $\left[F_{(3,40)}=11,56\right.$, $\mathrm{p}<0,0001]$. O teste de Bonferroni mostrou que:

1) As proles do grupo SM apresentaram um aumento de $\mathrm{DOR} / \boldsymbol{\alpha}$-tubulina no hipotálamo em relação ao grupo SS no primeiro terço da gestação;

2) As proles dos grupos MS e MM apresentaram uma diminuição de DOR/ $\alpha$-tubulina no hipotálamo em relação ao grupo SM no primeiro terço da gestação;

3) As proles do grupo MM apresentaram uma diminuição de DOR/ $\alpha$-tubulina no hipotálamo em relação ao grupo MS no primeiro terço da gestação.

A Figura 37 mostra a análise da expressão de Oprk1, Oprm1 e Oprd1 que codificam para os receptores opióides $\kappa, \mu$ e $\delta$ respectivamente, bem como os produtos protéicos KOR, MOR e DOR na PAG das proles masculinas de mães tratadas ou não com sulfato de morfina no primeiro ou segundo terços da gestação.

A Figura 37A mostra a análise da expressão de Oprk1 na PAG das proles masculinas. A ANOVA de duas vias não mostrou diferenças significantes entre os tratamentos $\left[\mathrm{F}_{(3,40)}=\right.$ $1,86, p=0,15]$, não observou-se diferenças significantes entre os períodos da gestação $\left[\mathrm{F}_{(1,40)}\right.$ $=0,02, p=0,89]$, tampouco interação entre os fatores $\left[F_{(3,40)}=1,72, p=0,17\right]$. O teste de Bonferroni indicou que as proles do grupo MM apresentaram um aumento na expressão de Oprk1 em relação aos grupos SM e MS no segundo terço da gestação.

Sobre o produto protéico KOR/ $\alpha$-tubulina na PAG das proles masculinas. A ANOVA de duas vias mostrou que houve diferenças significantes entre os tratamentos $\left[\mathrm{F}_{(3,40)}=12,87\right.$, $\mathrm{p}<0,0001$ ], observou-se também diferenças significantes entres os períodos da gestação 
$\left[F_{(1,40)}=226,6, p<0,0001\right]$ e foi observada interação entre os fatores $\left[F_{(3,40)}=18,80, p<\right.$ 0,0001]. O teste de Bonferroni mostrou que:

1) As proles do grupo MS apresentaram uma diminuição de $\mathrm{KOR} / \alpha$-tubulina na $\mathrm{PAG}$ em relação ao grupo SS no segundo terço da gestação;

2) As proles do grupo MM apresentaram um aumento de $\mathrm{KOR} / \alpha$-tubulina na $\mathrm{PAG}$ em relação ao grupo SS no segundo terço da gestação;

3) As proles dos grupos MS e MM apresentaram um aumento de KOR/ $\alpha$-tubulina na PAG em relação ao grupo SM no segundo terço da gestação.

A Figura 37B mostra a análise da expressão de Oprm1 na PAG de proles das masculinas. A ANOVA de duas vias não mostrou diferenças significantes entre os tratamentos $\left[\mathrm{F}_{(3,40)}=0,45, \mathrm{p}=0,72\right]$, não observou-se diferenças significantes entre os períodos da gestação $\left[\mathrm{F}_{(1,40)}=0,13, \mathrm{p}=0,71\right]$ bem como não houve interação entre os fatores $\left[\mathrm{F}_{(3,40)}=0,35, \mathrm{p}=0,78\right]$. $\mathrm{O}$ teste de Bonferroni não indicou diferenças significantes entre os diferentes grupos.

Sobre o produto protéico MOR/ $\alpha$-tubulina na PAG das proles masculinas. A ANOVA de duas vias mostrou que houve diferenças significantes entre os tratamentos $\left[\mathrm{F}_{(3,40)}=59,36\right.$, $\mathrm{p}<0,0001$ ], observou-se também diferenças significantes entres os períodos da gestação $\left[\mathrm{F}_{(1,40)}=1098, \mathrm{p}<0,0001\right]$ e foi observada interação entre os fatores $\left[\mathrm{F}_{(3,40)}=71,55, \mathrm{p}<\right.$ 0,0001]. O teste de Bonferroni mostrou que:

1) As proles dos grupos SM, MS e MM apresentaram um aumento de $M O R / \alpha$ tubulina na PAG em relação ao grupo SS no segundo terço da gestação;

2) As prole do grupo MM apresentaram um aumento de $M O R / \alpha$-tubulina na PAG em relação aos grupos SM e MS no segundo terço da gestação;

A Figura 37C mostra a análise da expressão de Oprd1 na PAG das proles masculinas. A ANOVA de duas vias não mostrou diferenças significantes entre os tratamentos $\left[\mathrm{F}_{(3,40)}=\right.$ $0,02, \mathrm{p}=0,99]$, não observou-se diferenças significantes entre os períodos da gestação $\left[\mathrm{F}_{(1,40)}\right.$ $=0,0, \mathrm{p}=1,0]$ e não houve interação entre os fatores $\left[\mathrm{F}_{(3,40)}=0,0, \mathrm{p}=1,0\right]$. O teste de Bonferroni não indicou diferenças significantes entre os diferentes grupos.

Sobre o produto protéico DOR/ $\alpha$-tubulina na PAG das proles masculinas. A ANOVA de duas vias mostrou que houve diferenças significantes entre os tratamentos $\left[\mathrm{F}_{(3,40)}=3,31, \mathrm{p}\right.$ $=0,03]$, observou-se também diferenças significantes entres os períodos da gestação $\left[\mathrm{F}_{(1,40)}=\right.$ 
$16,09, p=0,0003]$ e foi observada interação entre os fatores $\left[F_{(3,40)}=7,76, p=0,0004\right]$. O teste de Bonferroni mostrou que:

1) As proles dos grupos MS e MM apresentaram um aumento de DOR/ $\alpha$-tubulina na PAG em relação ao grupo SS no segundo terço da gestação;

2) As proles do grupo $M M$ apresentaram um aumento de $D O R / \alpha$-tubulina na PAG em relação ao grupo SM no segundo terço da gestação. 
Figura 29 - Análise da expressão de Oprk1, Oprm1 e Oprd1, bem como dos produtos protéicos KOR, MOR e DOR no estriado de ratas tratadas ou não com sulfato de morfina no primeiro e segundo terços da gestação.

A

$1^{0}$ Terço

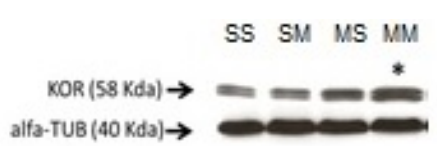

$2^{\circ}$ Terco

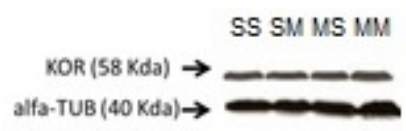

Estriado

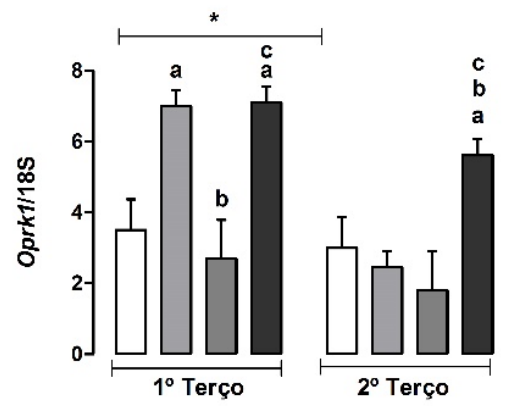

B

$$
1^{\circ} \text { Terço }
$$

SS SM MS MM

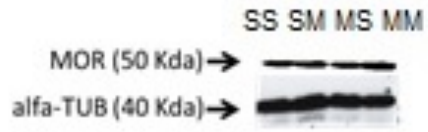

$2^{\circ}$ Terço

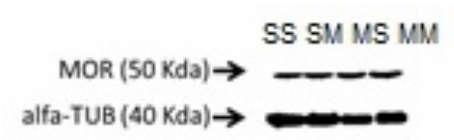

Estriado

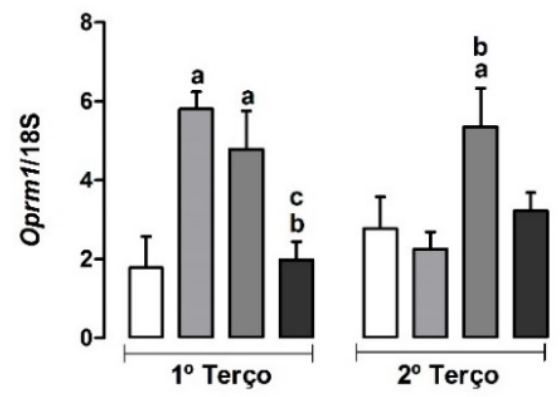




\section{C}

$1^{0}$ Terço

SS SM MS MM

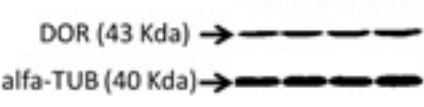

$2^{\circ}$ Terço

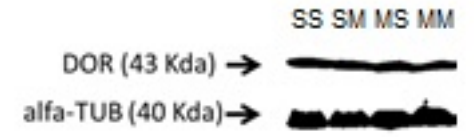

\section{Estriado}

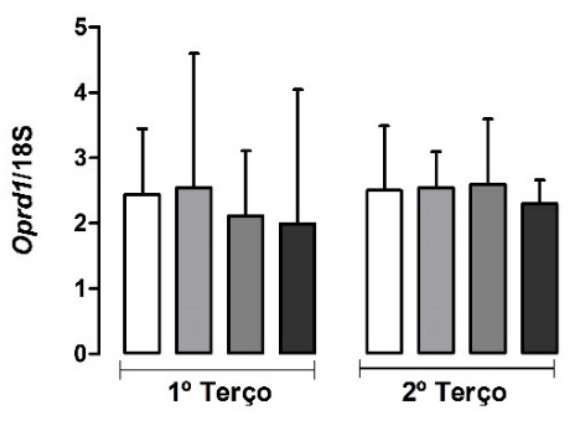

SS: tratamento durante a gestação com salina $0,9 \%$ e desafio no $5^{\circ}$ dia de lactação com salina $0,9 \%$; SM: tratamento durante a gestação com salina $0,9 \%$ e desafio no $5^{\circ}$ dia de lactação com $3,0 \mathrm{mg} / \mathrm{kg}$ de sulfato de morfina; MS: tratamento durante a gestação com $3,5 \mathrm{mg} / \mathrm{kg}$ de sulfato de morfina e desafio no $5^{\circ}$ dia de lactação com salina 0,9\%; MM: tratamento durante a gestação com 3,5mg/kg de sulfato de morfina e desafio no $5^{\circ}$ dia de lactação com 3,0mg/kg de sulfato de morfina. Em (A) expressão do gene Oprk1 no estriado de mães tratadas com sulfato de morfina ou salina no primeiro ou segundo terço da gestação. ANOVA de duas vias - diferenças significantes entre os tratamentos, fases da gestação com interação entre os fatores $\mathrm{p}<0,05$, seguida pelo teste de Bonferroni; $\mathbf{a}-\mathrm{p}>0,05$ comparados a SS em ambos os terços da gestação; $\mathbf{b}-\mathrm{p}>0,05$ comparados a SM em ambos os terços da gestação; $\mathbf{c}-\mathrm{p}<0,05$ comparados a MS em ambos os terços da gestação e * diferenças significantes entres os terços da gestação; (B) expressão do gene Oprm 1 no estriado de mães tratadas com sulfato de morfina ou salina no primeiro ou segundo terço da gestação. ANOVA de duas vias - diferenças significantes entre os tratamentos com interação entre os fatores $\mathrm{p}<0,05$, seguida pelo teste de Bonferroni; $\mathbf{a}-\mathrm{p}<0,05$ comparados a SS em ambos os terços da gestação; b - p < 0,05 comparados a SM em ambos os terços da gestação; $\mathbf{c}-\mathrm{p}<0,05$ comparado a MS no primeiro terço da gestação. Em (C) expressão do gene Oprd1 no estriado de mães tratadas com sulfato de morfina ou salina no primeiro ou segundo terço da gestação. ANOVA de duas vias $\mathrm{p}>0,05$. Western blot de amostras de estriado de ratas tratadas ou não com sulfato de morfina no primeiro ou segundo terços da gestação para as proteínas KOR (A), MOR (B) e DOR (C). Padrão de bandas em gel, seguido de reação ECL e e leitura MyECL Imager ${ }^{\circledR}$, sendo os dados normalizados em relação à $\alpha$ TUBULINA. São apresentadas as médias \pm erros-padrão $(n=6) . p>0,05$; ANOVA seguida pelo teste de Bonferroni. 
Figura 30 - Análise da expressão de Oprk1, Oprm1 e Oprd1, bem como dos produtos protéicos KOR, MOR e DOR no hipotálamo de ratas tratadas ou não com sulfato de morfina no primeiro e segundo terços da gestação.

A

$1^{0}$ Terço

SS SM MS MM

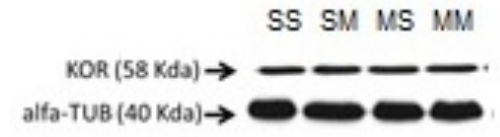

$2^{\circ}$ Terço

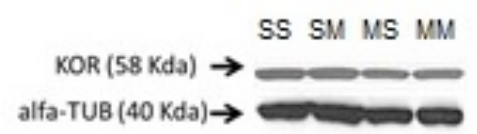

Hipotálamo

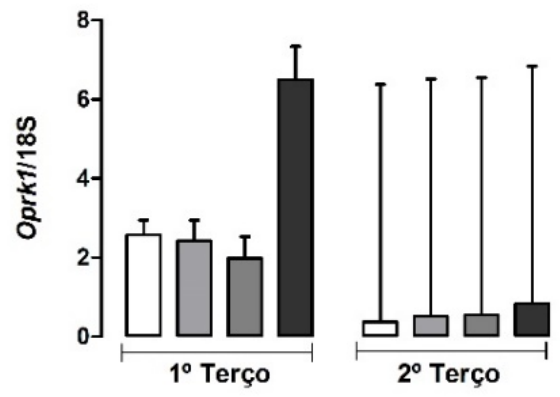

B

$1^{\circ}$ Terço

SS SM MS MM

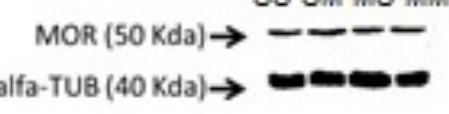

$2^{\circ}$ Terço

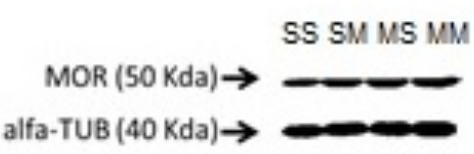

Hipotálamo

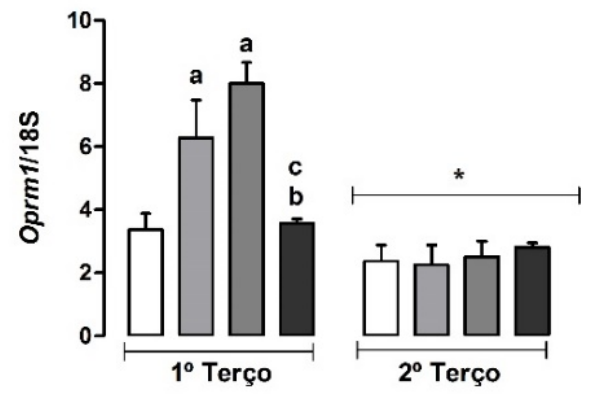


C

$1^{0}$ Terço

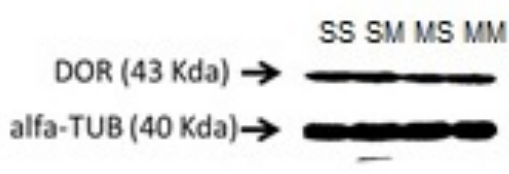

$2^{\circ}$ Terço

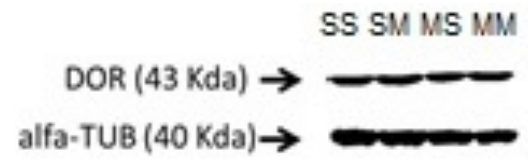

Hipotálamo

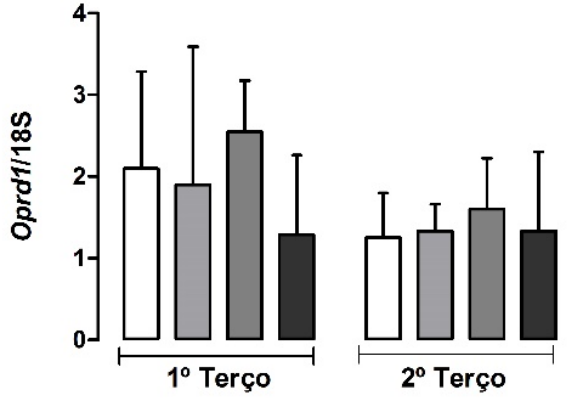


SS: tratamento durante a gestação com salina $0,9 \%$ e desafio no $5^{\circ}$ dia de lactação com salina $0,9 \%$; SM: tratamento durante a gestação com salina $0,9 \%$ e desafio no $5^{\circ}$ dia de lactação com $3,0 \mathrm{mg} / \mathrm{kg}$ de sulfato de morfina; MS: tratamento durante a gestação com $3,5 \mathrm{mg} / \mathrm{kg}$ de sulfato de morfina e desafio no $5^{\circ}$ dia de lactação com salina $0,9 \%$; MM: tratamento durante a gestação com $3,5 \mathrm{mg} / \mathrm{kg}$ de sulfato de morfina e desafio no $5^{\circ}$ dia de lactação com 3,0mg/kg de sulfato de morfina. Em (A) expressão do gene Oprk1 no hipotálamo de mães tratadas com sulfato de morfina ou salina no primeiro ou segundo terço da gestação. ANOVA de duas vias $p>0,05$. Em (B) expressão do gene Oprm1 no hipotálamo de mães tratadas com sulfato de morfina ou salina no primeiro ou segundo terço da gestação. ANOVA de duas vias - diferenças significantes entre os tratamentos, fases da gestação com interação entre os fatores $\mathrm{p}<0,05$, seguida pelo teste de Bonferroni; $\mathbf{a}-\mathrm{p}>0,05$ comparados a SS no primeiro terço da gestação; $\mathbf{b}-\mathrm{p}>0,05$ comparado a SM no primeiro terço da gestação; $\mathbf{c}-\mathrm{p}<0,05$ comparados a MS no primeiro terço da gestação e * diferenças significantes entres os terços da gestação. (C) expressão do gene $\operatorname{Prd} 1$ no hipotálamo de mães tratadas com sulfato de morfina ou salina no primeiro ou segundo terço da gestação. ANOVA de duas vias $p>0,05$. Os gráficos em barras representam os valores de densidade óptica relativa para Oprk1, Oprm1 e Oprd1, sendo os valores normalizados pelos produtos de qPCR correspondentes para $\beta$-actina e em relação às densidades do grupo controle. São apresentadas as médias e errospadrão $(n=6)$. Western blot de amostras de hipotálamo de ratas tratadas ou não com sulfato de morfina no primeiro ou segundo terços da gestação para as proteínas KOR (A), MOR (B) e DOR (C). Padrão de bandas em gel, seguido de reação ECL e e leitura MyECL Imager ${ }^{\circledR}$,, sendo os dados normalizados em relação à $\alpha$ TUBULINA.SS: tratamento durante a gestação com salina $0,9 \%$ e desafio no $5^{\circ}$ dia de lactação com salina $0,9 \%$; SM: tratamento durante a gestação com salina $0,9 \%$ e desafio no $5^{\circ}$ dia de lactação com $3,0 \mathrm{mg} / \mathrm{kg}$ de sulfato de morfina; MS: tratamento durante a gestação com $3,5 \mathrm{mg} / \mathrm{kg}$ de sulfato de morfina e desafio no $5^{\circ}$ dia de lactação com salina $0,9 \%$; MM: tratamento durante a gestação com $3,5 \mathrm{mg} / \mathrm{kg}$ de sulfato de morfina e desafio no $5^{\circ}$ dia de lactação com $3,0 \mathrm{mg} / \mathrm{kg}$ de sulfato de morfina. São apresentadas as médias \pm erros-padrão $(n=6)$. $p>0,05$; ANOVA seguida pelo teste de Bonferroni. 
Figura 31 - Análise da expressão de Oprk1, Oprm1 e Oprd1, bem como dos produtos protéicos KOR, MOR e DOR na PAG de ratas tratadas ou não com sulfato de morfina no primeiro e segundo terços da gestação.

A

$1^{0}$ Terço

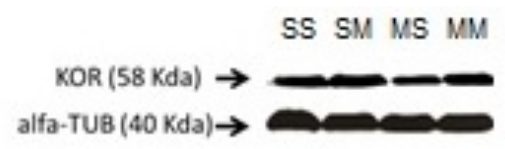

$2^{\circ}$ Terço

SS SM MS MM

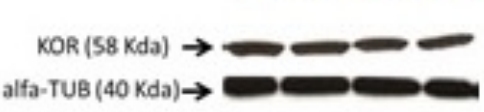

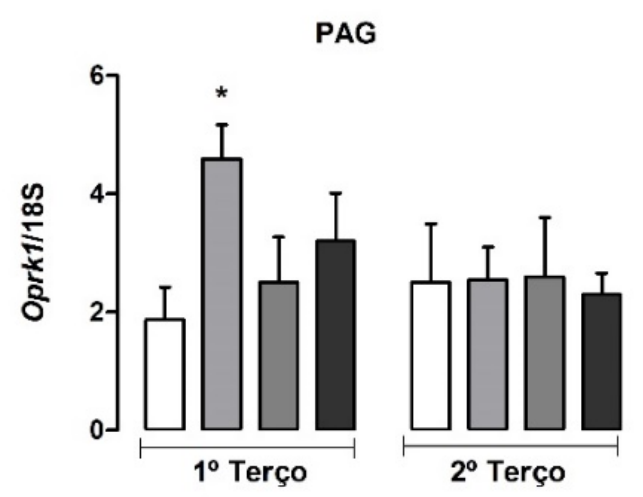

B

$1^{\circ}$ Terço

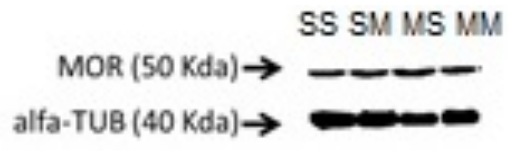

$2^{\circ}$ Terço

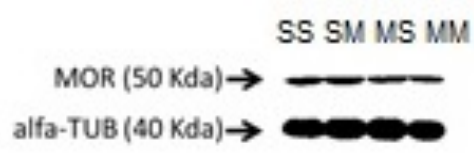

PAG

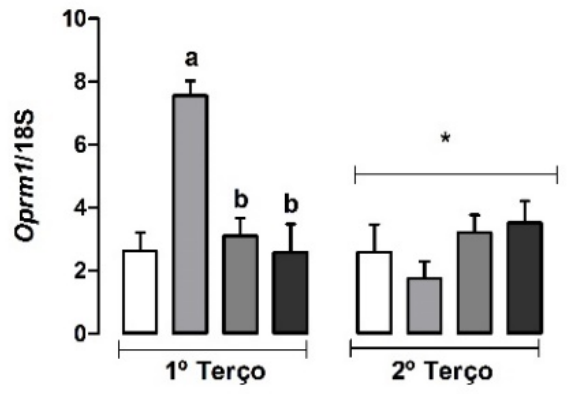


C

$1^{0}$ Terço

SS SM MS MM

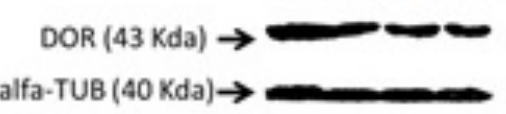

$2^{\circ}$ Terço

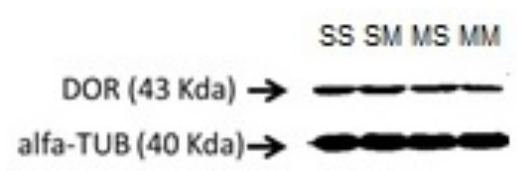

PAG

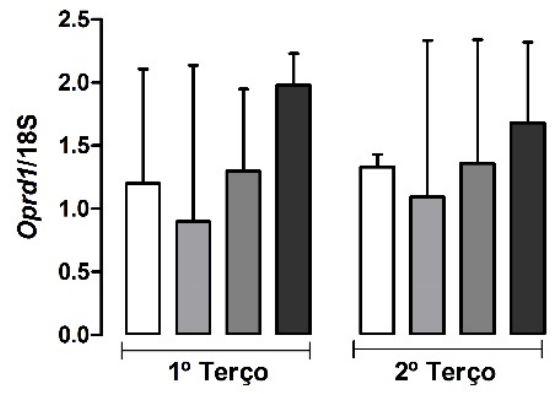


SS: tratamento durante a gestação com salina $0,9 \%$ e desafio no $5^{\circ}$ dia de lactação com salina $0,9 \%$; SM: tratamento durante a gestação com salina $0,9 \%$ e desafio no $5^{\circ}$ dia de lactação com $3,0 \mathrm{mg} / \mathrm{kg}$ de sulfato de morfina; MS: tratamento durante a gestação com $3,5 \mathrm{mg} / \mathrm{kg}$ de sulfato de morfina e desafio no $5^{\circ}$ dia de lactação com salina $0,9 \%$; MM: tratamento durante a gestação com $3,5 \mathrm{mg} / \mathrm{kg}$ de sulfato de morfina e desafio no $5^{\circ}$ dia de lactação com 3,0mg/kg de sulfato de morfina. Em (A) expressão do gene Oprk1 na PAG de mães tratadas com sulfato de morfina ou salina no primeiro ou segundo terço da gestação. ANOVA de duas vias $p>0,05$, seguida pelo teste de Bonferroni * p < 0,05 comparado a SS no primeiro terço da gestação. (B) expressão do gene Oprm 1 na PAG de mães tratadas com sulfato de morfina ou salina no primeiro ou segundo terço da gestação. ANOVA de duas vias- diferenças significantes entre os tratamentos, fases da gestação e interação entre os fatores $p<$ 0,05, seguida pelo teste de Bonferroni: $\mathbf{a}-\mathbf{p}<0,05$ comparado a SS; $\mathbf{b}-\mathbf{p}<0,05$ comparados a SM ambos no primeiro terço da gestação. .Em (C) expressão do gene Oprdl na PAG de mães tratadas com sulfato de morfina ou salina no primeiro ou segundo terço da gestação. ANOVA de duas vias $p>0,05$. Os gráficos em barras representam os valores de densidade óptica relativa para Oprk1, Oprm1 e Oprd1, sendo os valores normalizados pelos produtos de qPCR correspondentes para $\beta$-actina e em relação às densidades do grupo controle. São apresentadas as médias e erros-padrão $(n=6)$. Western blot de amostras de PAG de ratas tratadas ou não com sulfato de morfina no primeiro ou segundo terços da gestação para as proteínas KOR (A), MOR (B) e DOR (C). Padrão de bandas em gel, seguido de reação ECL e e leitura MyECL Imager ${ }^{\circledR}$, sendo os dados normalizados em relação à $\alpha$-TUBULINA.SS: tratamento durante a gestação com salina $0,9 \%$ e desafio no $5^{\circ}$ dia de lactação com salina $0,9 \%$; SM: tratamento durante a gestação com salina $0,9 \%$ e desafio no $5^{\circ}$ dia de lactação com $3,0 \mathrm{mg} / \mathrm{kg}$ de sulfato de morfina; MS: tratamento durante a gestação com $3,5 \mathrm{mg} / \mathrm{kg}$ de sulfato de morfina e desafio no $5^{\circ}$ dia de lactação com salina $0,9 \%$; MM: tratamento durante a gestação com $3,5 \mathrm{mg} / \mathrm{kg}$ de sulfato de morfina e desafio no $5^{\circ}$ dia de lactação com $3,0 \mathrm{mg} / \mathrm{kg}$ de sulfato de morfina. São apresentadas as médias \pm erros-padrão $(\mathrm{n}=6)$. $\mathrm{p}>$ 0,05; ANOVA seguida pelo teste de Bonferroni. 
Figura 32 - Análise da expressão de Oprk1, Oprm1 e Oprd1, bem como dos produtos protéicos KOR, MOR e DOR no estriado das proles femininas de ratas tratadas ou não com sulfato de morfina no primeiro e segundo terços da gestação.

A

$1^{\circ}$ Terço

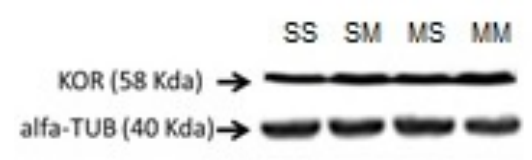

$2^{0}$ Terço

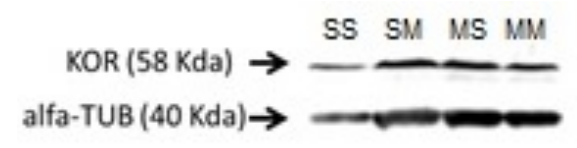

Estriado

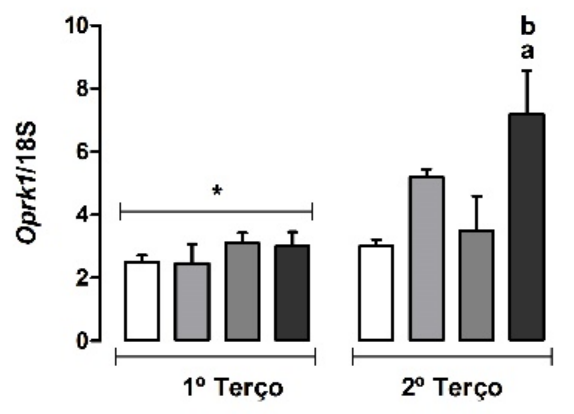

B

$1^{0}$ Terço

$2^{\circ}$ Terço

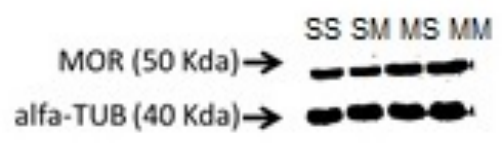

Estriado

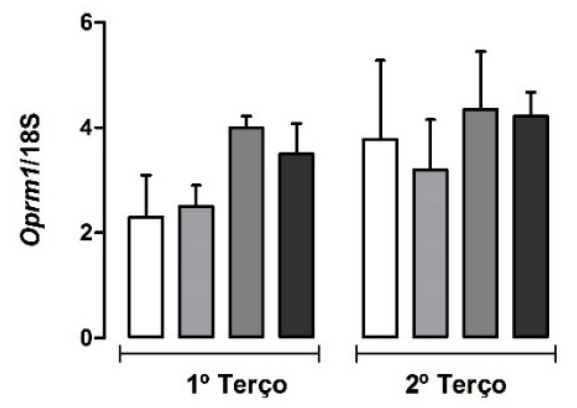


C

$1^{\circ}$ Terço

$\underset{\text { DOR }(43 \mathrm{Kda}) \rightarrow}{\rightarrow}$ SS SM MS MM $2^{\circ}$ Terço

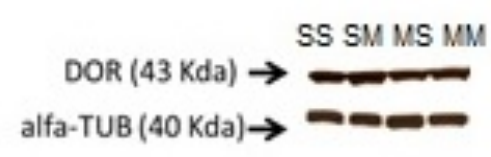

Estriado

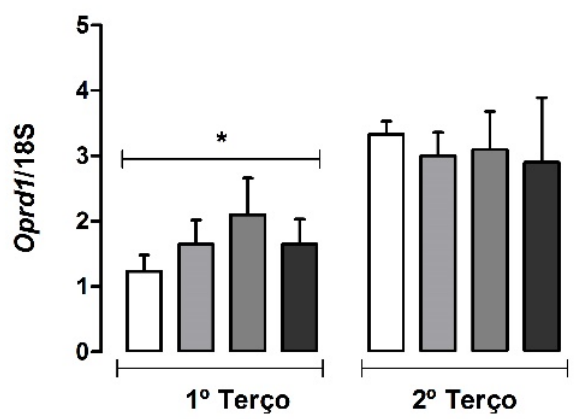


SS: tratamento durante a gestação com salina $0,9 \%$ e desafio no $5^{\circ}$ dia de lactação com salina $0,9 \%$; SM: tratamento durante a gestação com salina $0,9 \%$ e desafio no $5^{\circ}$ dia de lactação com $3,0 \mathrm{mg} / \mathrm{kg}$ de sulfato de morfina; MS: tratamento durante a gestação com $3,5 \mathrm{mg} / \mathrm{kg}$ de sulfato de morfina e desafio no $5^{\circ}$ dia de lactação com salina $0,9 \%$; MM: tratamento durante a gestação com $3,5 \mathrm{mg} / \mathrm{kg}$ de sulfato de morfina e desafio no $5^{\circ}$ dia de lactação com 3,0mg/kg de sulfato de morfina. Em (A) expressão do gene Oprk1 no estriado das proles femininas de mães tratadas com sulfato de morfina ou salina no primeiro ou segundo terço da gestação. ANOVA de duas vias - diferenças significantes entre os tratamentos, fases da gestação com interação entre os fatores $\mathrm{p}<$ 0,05, seguida pelo teste de Bonferroni; $\mathbf{a}-\mathbf{p}>0,05$ comparados a SS no segundo terço da gestação; $\mathbf{b}-\mathbf{p}>0,05$ comparados a MS no segundo terço da gestação e * diferenças significantes entres os terços da gestação. (B) expressão do gene Oprm 1 no estriado das proles femininas de mães tratadas com sulfato de morfina ou salina no primeiro ou segundo terço da gestação. ANOVA de duas vias p >0,05. Em (C) expressão do gene Oprd1 no estriado das proles femininas de mães tratadas com sulfato de morfina ou salina no primeiro ou segundo terço da gestação. ANOVA de duas vias mostrou significância entre as fases da gestação $p<0,05$. Os gráficos em barras representam os valores de densidade óptica relativa para Oprk1, Oprm1 e Oprd1, sendo os valores normalizados pelos produtos de qPCR correspondentes para $\beta$-actina e em relação às densidades do grupo controle. São apresentadas as médias e erros-padrão $(n=6)$. Western blot de amostras de estriado das proles femininas de ratas tratadas ou não com sulfato de morfina no primeiro ou segundo terços da gestação para as proteínas KOR (A), MOR (B) e DOR (C). Padrão de bandas em gel, seguido de reação ECL e leitura MyECL Imager $\AA$, sendo os dados normalizados em relação à $\alpha$-TUBULINA.SS: tratamento durante a gestação com salina $0,9 \%$ e desafio no $5^{\circ}$ dia de lactação com salina $0,9 \%$; SM: tratamento durante a gestação com salina $0,9 \%$ e desafio no $5^{\circ}$ dia de lactação com 3,0mg/kg de sulfato de morfina; MS: tratamento durante a gestação com 3,5mg/kg de sulfato de morfina e desafio no $5^{\circ}$ dia de lactação com salina $0,9 \%$; MM: tratamento durante a gestação com $3,5 \mathrm{mg} / \mathrm{kg}$ de sulfato de morfina e desafio no $5^{\circ}$ dia de lactação com $3,0 \mathrm{mg} / \mathrm{kg}$ de sulfato de morfina. São apresentadas as médias \pm erros-padrão ( $\mathrm{n}=6$ ). $\mathrm{p}>0,05$; ANOVA seguida pelo teste de Bonferroni. 
Figura 33 - Análise da expressão de Oprk1, Oprm1 e Oprd1, bem como dos produtos protéicos KOR, MOR e DOR no hipotálamo das proles femininas de ratas tratadas ou não com sulfato de morfina no primeiro e segundo terços da

A

$1^{\circ}$ Terço

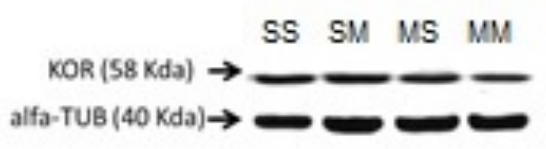

$\mathbf{2}^{\circ}$ Terço

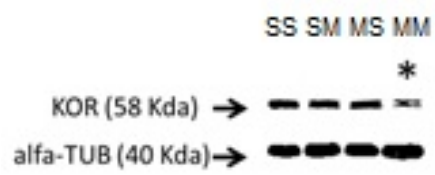

Hipotálamo

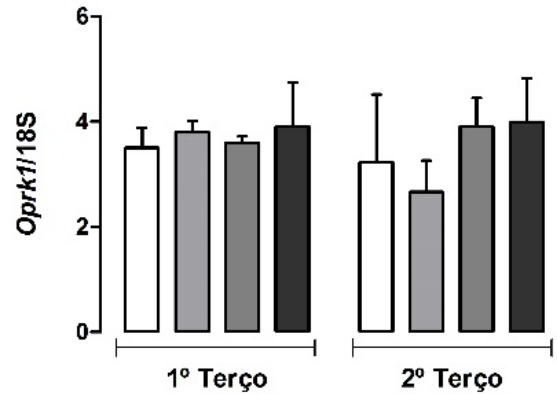

B
$1^{0}$ Terço
$2^{\circ}$ Terço

SS SM MS MM
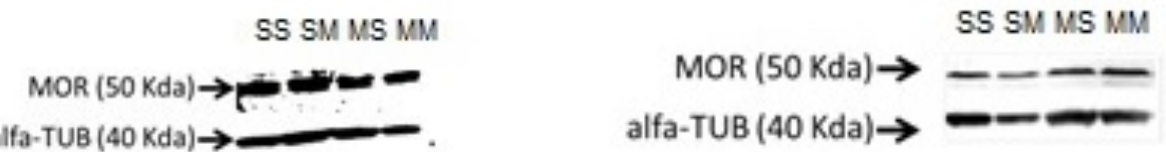

Hipotálamo

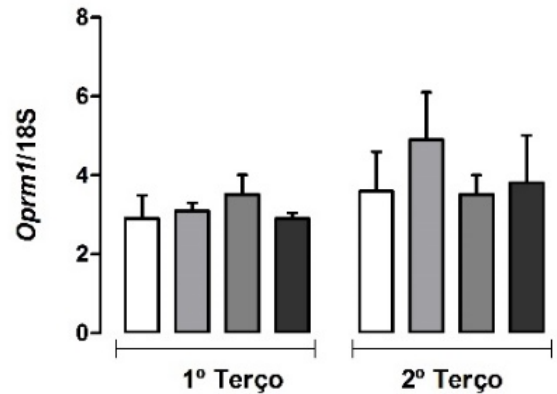


C

$1^{\circ}$ Terço

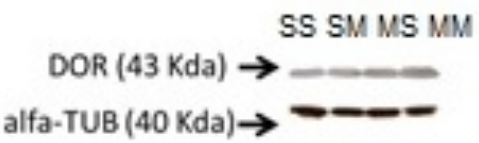

$2^{\circ}$ Terço

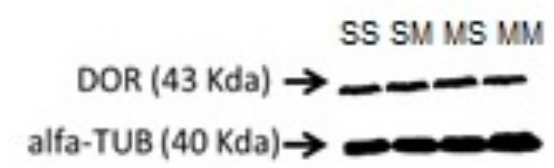

Hipotálamo

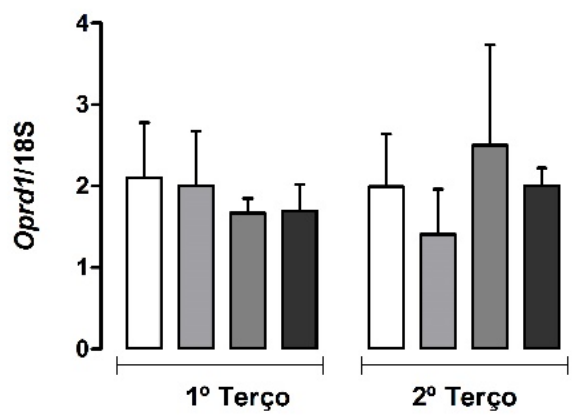


SS: tratamento durante a gestação com salina $0,9 \%$ e desafio no $5^{\circ}$ dia de lactação com salina $0,9 \%$; SM: tratamento durante a gestação com salina $0,9 \%$ e desafio no $5^{\circ}$ dia de lactação com $3,0 \mathrm{mg} / \mathrm{kg}$ de sulfato de morfina; MS: tratamento durante a gestação com $3,5 \mathrm{mg} / \mathrm{kg}$ de sulfato de morfina e desafio no $5^{\circ}$ dia de lactação com salina $0,9 \%$; MM: tratamento durante a gestação com $3,5 \mathrm{mg} / \mathrm{kg}$ de sulfato de morfina e desafio no $5^{\circ}$ dia de lactação com $3,0 \mathrm{mg} / \mathrm{kg}$ de sulfato de morfina. (A) expressão do gene Oprkl no hipotálamo das proles femininas de mães tratadas com sulfato de morfina ou salina no primeiro ou segundo terço da gestação. ANOVA de duas vias $\mathrm{p}>0,05$. Em (B) expressão do gene Oprm1 no hipotálamo das proles femininas de mães tratadas com sulfato de morfina ou salina no primeiro ou segundo terço da gestação. ANOVA de duas vias $p>0,05$. (C) expressão do gene $\operatorname{Oprdl}$ no hipotálamo das proles femininas de mães tratadas com sulfato de morfina ou salina no primeiro ou segundo terço da gestação. ANOVA de duas vias $p>0,05$. Os gráficos em barras representam os valores de densidade óptica relativa para $O p r k 1$, Oprm1 e $\operatorname{Oprd1}$, sendo os valores normalizados pelos produtos de qPCR correspondentes para $\beta$-actina e em relação às densidades do grupo controle. São apresentadas as médias e erros-padrão $(n=6)$. Western blot de amostras de hipotálamo das proles femininas de ratas tratadas ou não com sulfato de morfina no primeiro ou segundo terços da gestação para as proteínas KOR (A), MOR (B) e DOR (C). Padrão de bandas em gel, seguido de reação ECL e e leitura MyECL Imager ${ }^{\circledR}$, sendo os dados normalizados em relação à $\alpha$-TUBULINA.SS: tratamento durante a gestação com salina $0,9 \%$ e desafio no $5^{\circ}$ dia de lactação com salina $0,9 \%$; SM: tratamento durante a gestação com salina $0,9 \%$ e desafio no $5^{\circ}$ dia de lactação com $3,0 \mathrm{mg} / \mathrm{kg}$ de sulfato de morfina; MS: tratamento durante a gestação com $3,5 \mathrm{mg} / \mathrm{kg}$ de sulfato de morfina e desafio no $5^{\circ}$ dia de lactação com salina $0,9 \%$; MM: tratamento durante a gestação com $3,5 \mathrm{mg} / \mathrm{kg}$ de sulfato de morfina e desafio no $5^{\circ}$ dia de lactação com $3,0 \mathrm{mg} / \mathrm{kg}$ de sulfato de morfina. São apresentadas as médias \pm errospadrão ( $n=6)$. $p>0,05$; ANOVA seguida pelo teste de Bonferroni 
Figura 34 - Análise da expressão de Oprk1, Oprm1 e Oprd1, bem como dos produtos protéicos KOR, MOR e DOR na PAG das proles femininas de ratas tratadas ou não com sulfato de morfina no primeiro e segundo terços da gestação.

A

$1^{\circ}$ Terço

SS SM MS MM

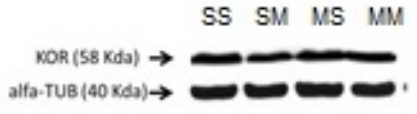

$2^{\circ}$ Terço

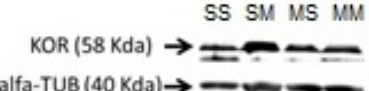

alfa-TUB (40 Kda) $\rightarrow-$

PAG

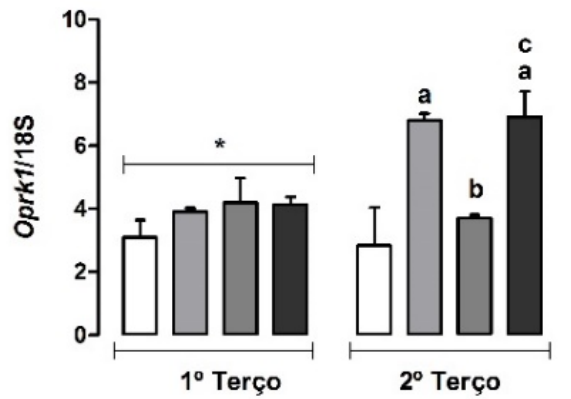

B

$1^{\circ}$ Terço

SS SM MS MM

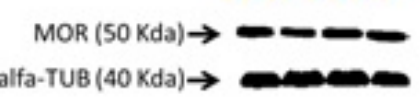

$2^{\circ}$ Terço

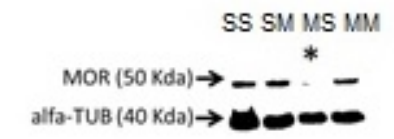

PAG

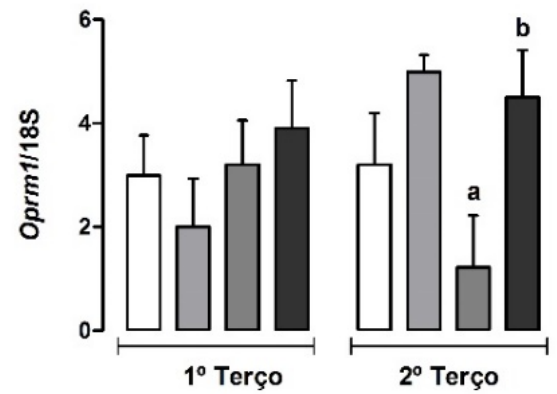

C 
$1^{\circ}$ Terço

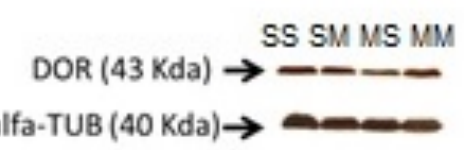

$2^{\circ}$ Terço

SS SM MS MM

$$
\begin{array}{r}
\text { DOR }(43 \mathrm{Kda}) \rightarrow== \\
\text { alfa-TUB }(40 \mathrm{Kda}) \rightarrow-
\end{array}
$$

PAG

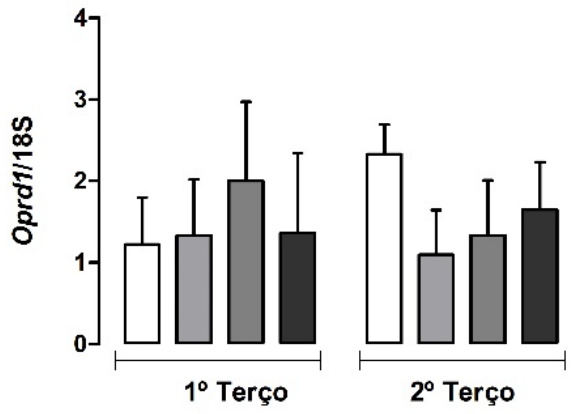


SS: tratamento durante a gestação com salina $0,9 \%$ e desafio no $5^{\circ}$ dia de lactação com salina $0,9 \%$; SM: tratamento durante a gestação com salina $0,9 \%$ e desafio no $5^{\circ}$ dia de lactação com $3,0 \mathrm{mg} / \mathrm{kg}$ de sulfato de morfina; MS: tratamento durante a gestação com $3,5 \mathrm{mg} / \mathrm{kg}$ de sulfato de morfina e desafio no $5^{\circ}$ dia de lactação com salina $0,9 \%$; MM: tratamento durante a gestação com $3,5 \mathrm{mg} / \mathrm{kg}$ de sulfato de morfina e desafio no $5^{\circ}$ dia de lactação com 3,0mg/kg de sulfato de morfina. Em (A) expressão do gene Oprkl na PAG das proles femininas de mães tratadas com sulfato de morfina ou salina no primeiro ou segundo terço da gestação. ANOVA de duas vias - diferenças significantes entre os tratamentos, fases da gestação com interação entre os fatores $p<0,05$, seguida pelo teste de Bonferroni; $\mathbf{a}-\mathrm{p}>0,05$ comparados a SS no segundo terço da gestação; $\mathbf{b}-\mathrm{p}>0,05$ comparados a SM no segundo terço da gestação; $\mathbf{c}-\mathrm{p}<0,05$ comparados a MS no segundo terço da gestação e * diferenças significantes entres os terços da gestação. (B) expressão do gene Oprm1 na PAG das proles femininas de mães tratadas com sulfato de morfina ou salina no primeiro ou segundo terço da gestação, $\mathbf{a}-\mathrm{p}<0,05$ comparado a SM; $\mathbf{b}-\mathbf{p}<\mathbf{0 , 0 5}$ comprado a MS ambos no segundo terço da gestação. . Em (C) expressão do gene Oprd1 na PAG das proles femininas de mães tratadas com sulfato de morfina ou salina no primeiro ou segundo terço da gestação. ANOVA de duas vias $\mathrm{p}>0,05$. Os gráficos em barras representam os valores de densidade óptica relativa para Oprk1, Oprm1 e Oprd1, sendo os valores normalizados pelos produtos de qPCR correspondentes para $\beta$-actina e em relação às densidades do grupo controle. São apresentadas as médias e erros-padrão $(\mathrm{n}=6)$. Western blot de amostras de PAG das proles femininas de ratas tratadas ou não com sulfato de morfina no primeiro ou segundo terços da gestação para as proteínas KOR (A), MOR (B) e DOR (C). Padrão de bandas em gel, seguido de reação ECL e e leitura MyECL Imager ${ }^{\circ}$, sendo os dados normalizados em relação à $\alpha$ TUBULINA.SS: tratamento durante a gestação com salina $0,9 \%$ e desafio no $5^{\circ}$ dia de lactação com salina $0,9 \%$; SM: tratamento durante a gestação com salina $0,9 \%$ e desafio no $5^{\circ}$ dia de lactação com $3,0 \mathrm{mg} / \mathrm{kg}$ de sulfato de morfina; MS: tratamento durante a gestação com $3,5 \mathrm{mg} / \mathrm{kg}$ de sulfato de morfina e desafio no $5^{\circ}$ dia de lactação com salina $0,9 \%$; MM: tratamento durante a gestação com $3,5 \mathrm{mg} / \mathrm{kg}$ de sulfato de morfina e desafio no $5^{\circ}$ dia de lactação com $3,0 \mathrm{mg} / \mathrm{kg}$ de sulfato de morfina. São apresentadas as médias \pm erros-padrão $(n=6)$. p > 0,05; ANOVA seguida pelo teste de Bonferroni. 
Figura 35 - Análise da expressão de Oprk1, Oprm1 e Oprd1, bem como dos produtos protéicos KOR, MOR e DOR no estriado das proles masculinas de ratas tratadas ou não com sulfato de morfina no primeiro e segundo terços da

A

$1^{\circ}$ Terço

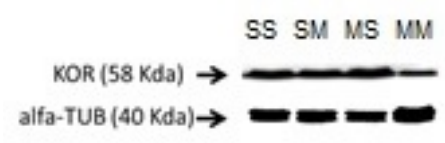

$2^{\circ}$ Terço

SS SM MS MM

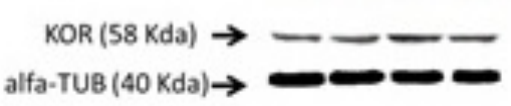

Estriado

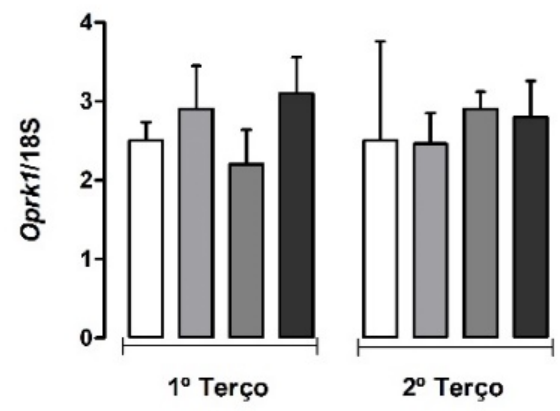

B

$1^{\circ}$ Terço

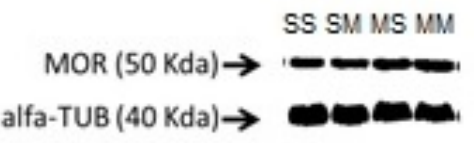

$2^{\circ}$ Terco

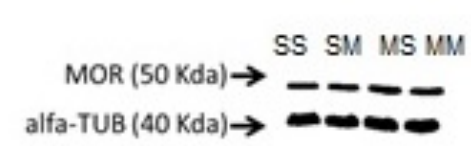

Estriado

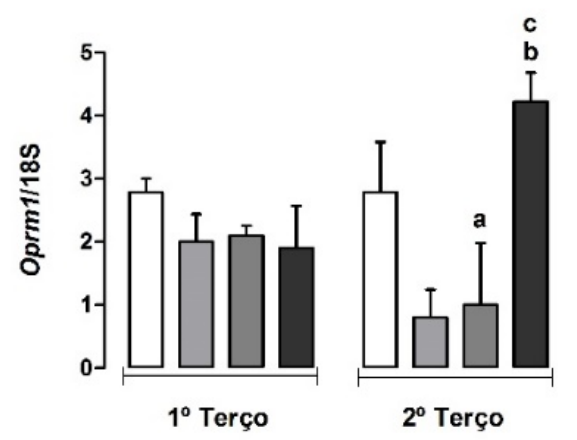


C

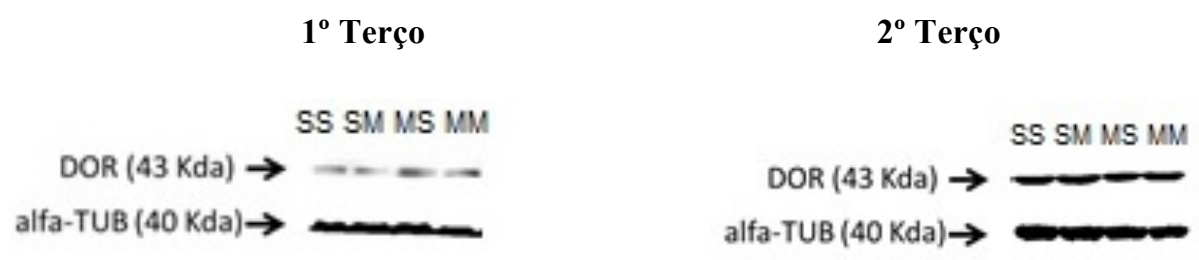

Estriado

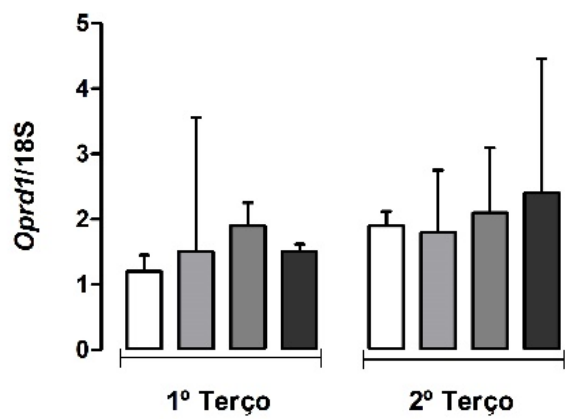


SS: tratamento durante a gestação com salina $0,9 \%$ e desafio no $5^{\circ}$ dia de lactação com salina $0,9 \%$; SM: tratamento durante a gestação com salina $0,9 \%$ e desafio no $5^{\circ}$ dia de lactação com $3,0 \mathrm{mg} / \mathrm{kg}$ de sulfato de morfina; MS: tratamento durante a gestação com $3,5 \mathrm{mg} / \mathrm{kg}$ de sulfato de morfina e desafio no $5^{\circ}$ dia de lactação com salina $0,9 \%$; MM: tratamento durante a gestação com $3,5 \mathrm{mg} / \mathrm{kg}$ de sulfato de morfina e desafio no $5^{\circ}$ dia de lactação com $3,0 \mathrm{mg} / \mathrm{kg}$ de sulfato de morfina. Em (A) expressão do gene Oprkl no estriado das proles masculinas de mães tratadas com sulfato de morfina ou salina no primeiro ou segundo terço da gestação. ANOVA de duas vias $\mathrm{p}>0,05$. (B) expressão do gene Oprm1 no estriado das proles masculinas de mães tratadas com sulfato de morfina ou salina no primeiro ou segundo terço da gestação. ANOVA de duas vias diferenças significantes entre os tratamentos com interação entre os fatores, seguida pelo teste de Bonferroni; a $\mathrm{p}<0,05$ comparado a SS; $\mathbf{b}-\mathrm{p}<0,05$ comparado a SM; $\mathbf{c}-\mathbf{p}<0,05$ comparado a MS todos no segundo terço da gestação. Em (C) expressão do gene $\operatorname{Oprd} 1$ no estriado das proles masculinas de mães tratadas com sulfato de morfina ou salina no primeiro ou segundo terço da gestação. ANOVA de duas vias $p>0,05$. Os gráficos em barras representam os valores de densidade óptica relativa para Oprk1, Oprm1 e Oprd1, sendo os valores normalizados pelos produtos de $\mathrm{qPCR}$ correspondentes para $\beta$-actina e em relação às densidades do grupo controle. São apresentadas as médias e erros-padrão $(n=6)$. Western blot de amostras de estriado das proles masculinas de ratas tratadas ou não com sulfato de morfina no primeiro ou segundo terços da gestação para as proteínas KOR (A), MOR (B) e DOR (C). Padrão de bandas em gel, seguido de reação ECL e leitura MyECL Imager ${ }^{\circledR}$, sendo os dados normalizados em relação à $\alpha$-TUBULINA.SS: tratamento durante a gestação com salina $0,9 \%$ e desafio no $5^{\circ}$ dia de lactação com salina $0,9 \%$; SM: tratamento durante a gestação com salina $0,9 \%$ e desafio no $5^{\circ}$ dia de lactação com $3,0 \mathrm{mg} / \mathrm{kg}$ de sulfato de morfina; MS: tratamento durante a gestação com $3,5 \mathrm{mg} / \mathrm{kg}$ de sulfato de morfina e desafio no $5^{\circ}$ dia de lactação com salina $0,9 \%$; MM: tratamento durante a gestação com $3,5 \mathrm{mg} / \mathrm{kg}$ de sulfato de morfina e desafio no $5^{\circ}$ dia de lactação com $3,0 \mathrm{mg} / \mathrm{kg}$ de sulfato de morfina. São apresentadas as médias \pm erros-padrão $(n=6)$. $p>0,05$; ANOVA seguida pelo teste de Bonferroni. 
Figura 36 - Análise da expressão de Oprk1, Oprm1 e Oprd1, bem como dos produtos protéicos KOR, MOR e DOR no hipotálamo das proles masculinas de ratas tratadas ou não com sulfato de morfina no primeiro e segundo terços da

A

$1^{\circ}$ Terço $\quad 2^{\circ}$ Terço

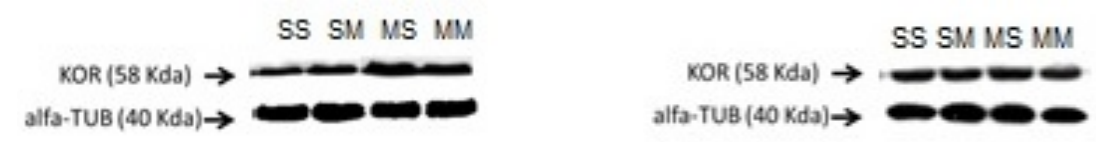

Hipotálamo

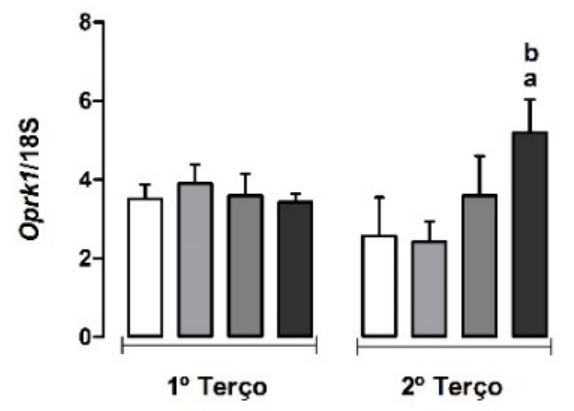

B

$\mathbf{1}^{\circ}$ Terço $\quad 2^{\circ}$ Terço

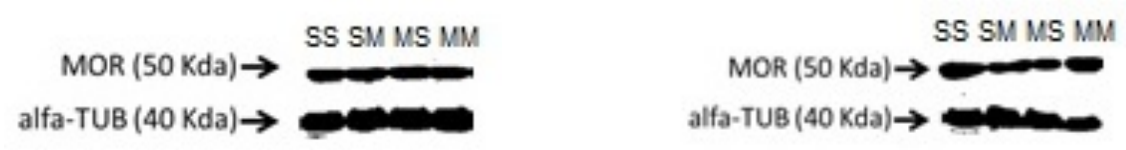

Hipotálamo

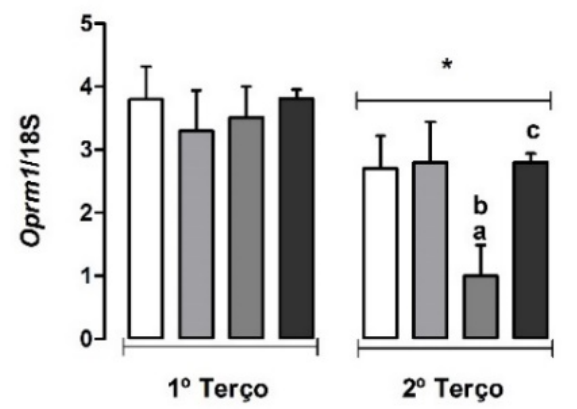


C

$1^{\circ}$ Terço

SS SM MS MM

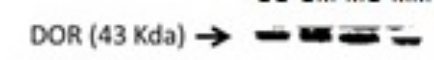

alfa-TUB (40 Kda) $\rightarrow$ $2^{\circ}$ Terço

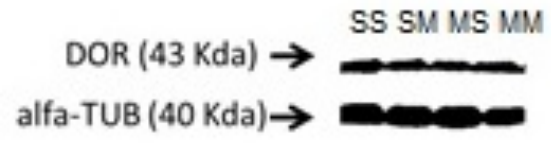

Hipotálamo

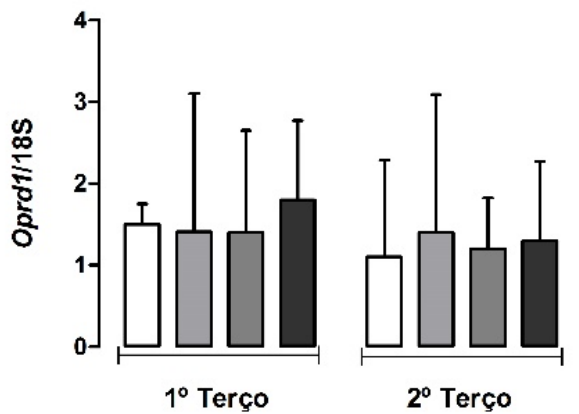


SS: tratamento durante a gestação com salina $0,9 \%$ e desafio no $5^{\circ}$ dia de lactação com salina $0,9 \%$; SM: tratamento durante a gestação com salina $0,9 \%$ e desafio no $5^{\circ}$ dia de lactação com $3,0 \mathrm{mg} / \mathrm{kg}$ de sulfato de morfina; MS: tratamento durante a gestação com $3,5 \mathrm{mg} / \mathrm{kg}$ de sulfato de morfina e desafio no $5^{\circ}$ dia de lactação com salina $0,9 \%$; MM: tratamento durante a gestação com $3,5 \mathrm{mg} / \mathrm{kg}$ de sulfato de morfina e desafio no $5^{\circ}$ dia de lactação com 3,0mg/kg de sulfato de morfina. Em (A) expressão do gene Oprk1 no hipotálamo das proles masculinas de mães tratadas com sulfato de morfina ou salina no primeiro ou segundo terço da gestação. ANOVA de duas vias $\mathrm{p}>0,05$, seguida pelo teste de Bonferroni $\mathbf{a}-\mathrm{p}<0,05$ comparado a SS; $\mathbf{b}-\mathrm{p}<0,05$ comparado a SM ambos no segundo terço da gestação. Em (B) expressão do gene Oprm1 no hipotálamo das proles masculinas de mães tratadas com sulfato de morfina ou salina no primeiro ou segundo terço da gestação. ANOVA de duas vias - diferenças significantes entre as fases de gestação, seguida pelo teste de Bonferroni; a $\mathrm{p}<0,05$ comparado a SS; $\mathbf{b}-\mathrm{p}<0,05$ comparado a SM; $\mathbf{c}-\mathrm{p}<0,05$ comparado a MS todos no segundo terço da gestação. (C) expressão do gene Oprdl no hipotálamo das proles masculinas de mães tratadas com sulfato de morfina ou salina no primeiro ou segundo terço da gestação. ANOVA de duas vias $p>0,05$. Os gráficos em barras representam os valores de densidade óptica relativa para Oprk1, Oprm1 e Oprd1, sendo os valores normalizados pelos produtos de qPCR correspondentes para $\beta$-actina e em relação às densidades do grupo controle. São apresentadas as médias e erros-padrão $(n=6)$. Western blot de amostras de hipotálamo das proles masculinas de ratas tratadas ou não com sulfato de morfina no primeiro ou segundo terços da gestação para as proteínas KOR (A), MOR (B) e DOR (C). Padrão de bandas em gel, seguido de reação ECL e leitura MyECL Imager ${ }^{\circledR}$, sendo os dados normalizados em relação à $\alpha$-TUBULINA.SS: tratamento durante a gestação com salina $0,9 \%$ e desafio no $5^{\circ}$ dia de lactação com salina $0,9 \%$; SM: tratamento durante a gestação com salina $0,9 \%$ e desafio no $5^{\circ}$ dia de lactação com $3,0 \mathrm{mg} / \mathrm{kg}$ de sulfato de morfina; MS: tratamento durante a gestação com $3,5 \mathrm{mg} / \mathrm{kg}$ de sulfato de morfina e desafio no $5^{\circ}$ dia de lactação com salina $0,9 \%$; MM: tratamento durante a gestação com $3,5 \mathrm{mg} / \mathrm{kg}$ de sulfato de morfina e desafio no $5^{\circ}$ dia de lactação com $3,0 \mathrm{mg} / \mathrm{kg}$ de sulfato de morfina. São apresentadas as médias \pm erros-padrão $(n=6)$. $p>0,05$; ANOVA seguida pelo teste de Bonferroni. 
Figura 37 - Análise da expressão de Oprk1, Oprm1 e Oprd1, bem como dos produtos protéicos KOR, MOR e DOR na PAG das proles masculinas de ratas tratadas ou não com sulfato de morfina no primeiro e segundo terços da gestação.

A

$\mathbf{1}^{\circ}$ Terço

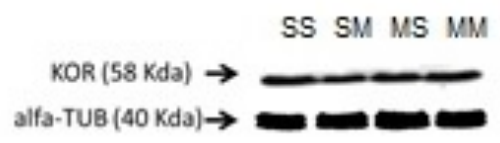

$2^{\circ}$ Terço

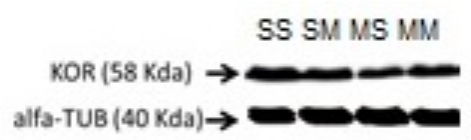

PAG

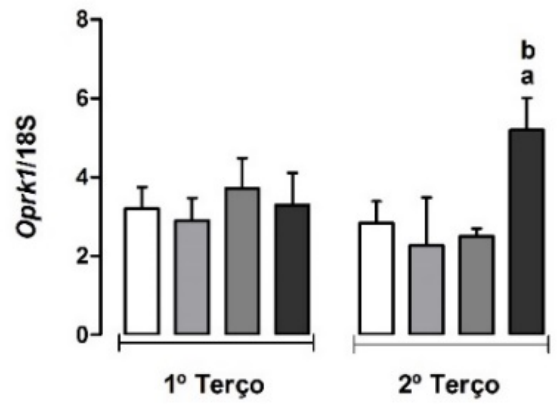

B

$1^{\circ}$ Terço

SS SM MS MM

MOR (50 Kda) $\rightarrow$ - - -

alfa-TUB $(40 \mathrm{Kda}) \rightarrow$ $2^{\circ}$ Terço

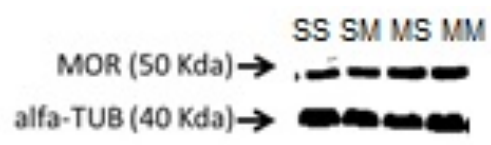

PAG
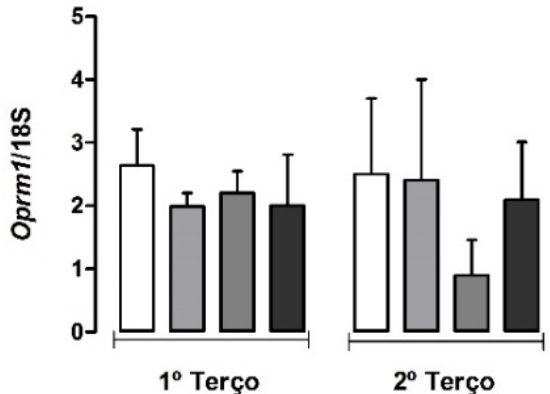
C

$1^{\circ}$ Terço

SS SM MS MM

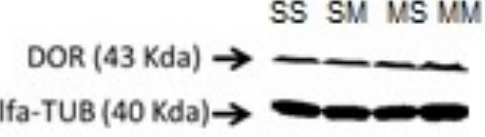

$2^{\circ}$ Terço

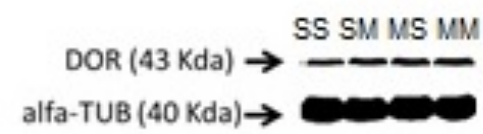

PAG

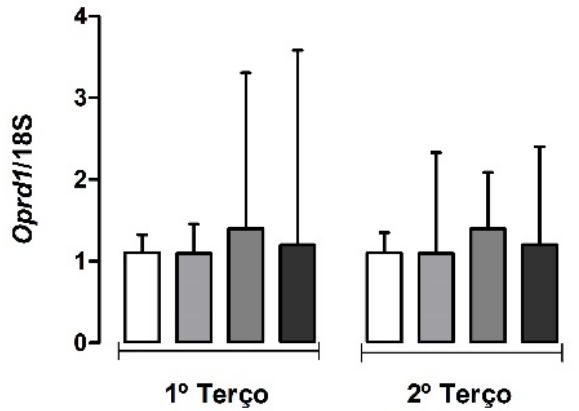


SS: tratamento durante a gestação com salina $0,9 \%$ e desafio no $5^{\circ}$ dia de lactação com salina $0,9 \%$; SM: tratamento durante a gestação com salina $0,9 \%$ e desafio no $5^{\circ}$ dia de lactação com $3,0 \mathrm{mg} / \mathrm{kg}$ de sulfato de morfina; MS: tratamento durante a gestação com $3,5 \mathrm{mg} / \mathrm{kg}$ de sulfato de morfina e desafio no $5^{\circ}$ dia de lactação com salina $0,9 \%$; MM: tratamento durante a gestação com $3,5 \mathrm{mg} / \mathrm{kg}$ de sulfato de morfina e desafio no $5^{\circ}$ dia de lactação com 3,0mg/kg de sulfato de morfina. Em (A) expressão do gene Oprkl na PAG das proles masculinas de mães tratadas com sulfato de morfina ou salina no primeiro ou segundo terço da gestação. ANOVA de duas vias $\mathrm{p}>0,05$, seguida pelo teste de Bonferroni $\mathbf{a}-\mathrm{p}<0,05$ comparado a SM; $\mathbf{b}-\mathrm{p}<0,05$ comparado a MS ambos no segundo terço da gestação. (B) expressão do gene Oprm1 na PAG das proles de das proles masculinas de mães tratadas com sulfato de morfina ou salina no primeiro ou segundo terço da gestação. ANOVA de duas vias $\mathrm{p}>0,05$. Em (I) expressão do gene Oprd1 na PAG das proles masculinas de mães tratadas com sulfato de morfina ou salina no primeiro ou segundo terço da gestação. ANOVA de duas vias $p>0,05$. Os gráficos em barras representam os valores de densidade óptica relativa para Oprk1, Oprml e Oprd1, sendo os valores normalizados pelos produtos de $\mathrm{qPCR}$ correspondentes para $\beta$-actina e em relação às densidades do grupo controle. São apresentadas as médias e erros-padrão $(n=6)$. Western blot de amostras de PAG das proles masculinas de ratas tratadas ou não com sulfato de morfina no primeiro ou segundo terços da gestação para as proteínas KOR (A), MOR (B) e DOR (C). Padrão de bandas em gel, seguido de reação ECL e leitura MyECL Imager ${ }^{\circledR}$, sendo os dados normalizados em relação à $\alpha$-TUBULINA.SS: tratamento durante a gestação com salina $0,9 \%$ e desafio no $5^{\circ}$ dia de lactação com salina $0,9 \%$; SM: tratamento durante a gestação com salina $0,9 \%$ e desafio no $5^{\circ}$ dia de lactação com $3,0 \mathrm{mg} / \mathrm{kg}$ de sulfato de morfina; MS: tratamento durante a gestação com $3,5 \mathrm{mg} / \mathrm{kg}$ de sulfato de morfina e desafio no $5^{\circ}$ dia de lactação com salina $0,9 \%$; MM: tratamento durante a gestação com 3,5mg/kg de sulfato de morfina e desafio no $5^{\circ}$ dia de lactação com 3,0mg/kg de sulfato de morfina. São apresentadas as médias \pm erros-padrão $(n=6)$. $p>0,05$; ANOVA seguida pelo teste de Bonferroni. 


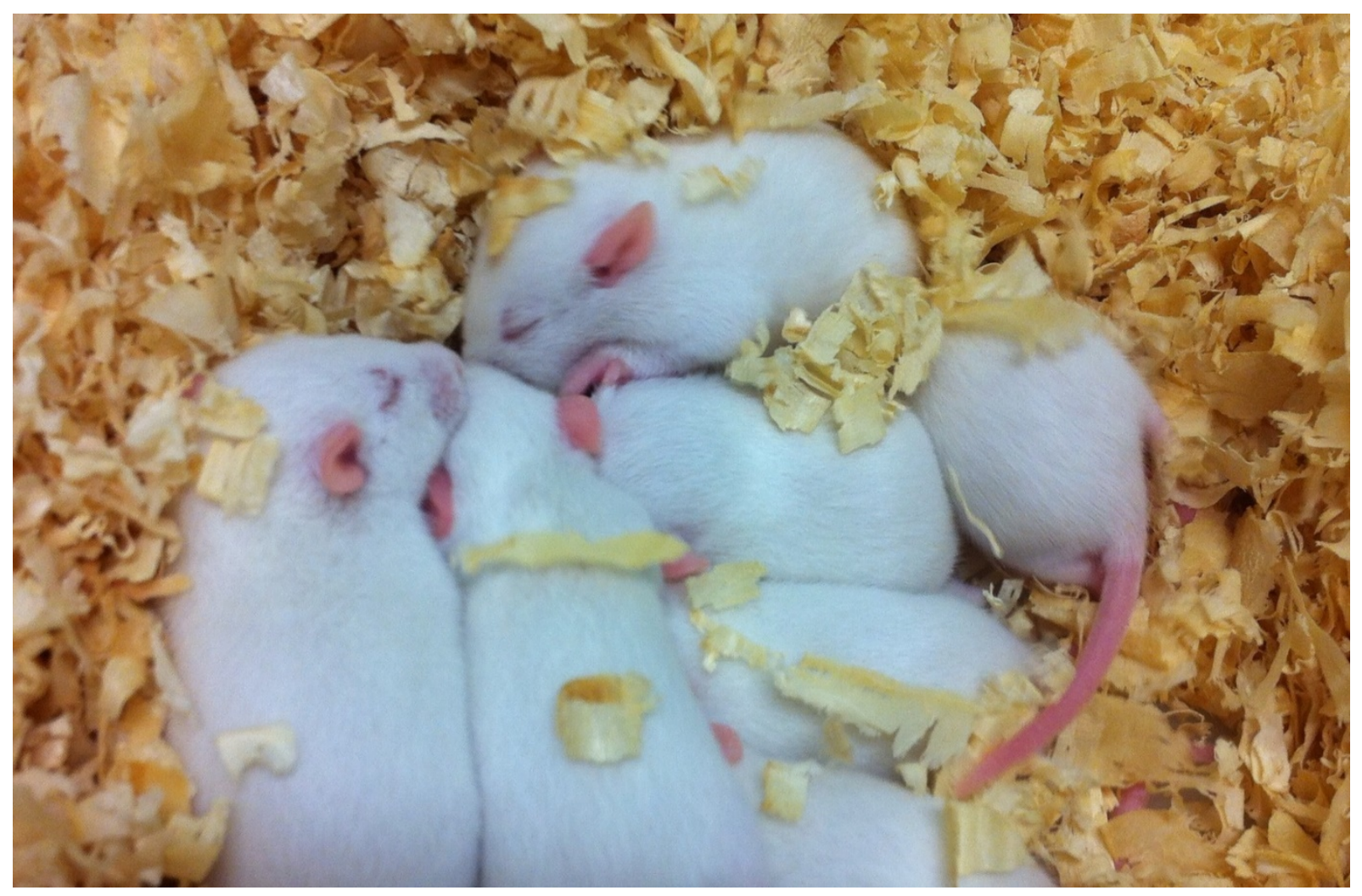

5 DISCUSSÃO 
Os opióides são substâncias de origem endógena ou sintética, referindo-se de forma ampla a todos os compostos relacionados ao ópio. O termo opium deriva da palavra grega opus, que significa suco, pois o fármaco é obtido a partir do suco da papoula - Papaver somniferum (GUTSTEIN; AKIL, 2005).

O sistema opióide endógeno é formado por um conjunto de receptores e peptídeos ligantes endógenos que estão amplamente distribuídos pelo SNC e também tecidos periféricos como sistemas imune, cardiovascular, endócrino e o trato digestório (BODNAR, 2009, 2012; WALDHOER; BARTLETT; WHISTLER, 2004). Existe pelo menos uma dúzia de ligantes opioidérgicos endógenos, embora o número de receptores seja limitado, sendo os principais os receptores $\mu$, к e $\delta$ (GUTSTEIN; AKIL, 2005).

Estudos que utilizaram critérios farmacológicos sugerem a existência de subtipos de receptores opióides, entretanto, foram isolados genes que codificam um subtipo de cada uma das famílias de receptores que foram devidamente caracterizados. Uma explicação é de que os subtipos de receptores surgem de variantes de splicing alternativo de um gene comum (PASTERNAK; STANDIFER, 1995). Nesse estudo foram utilizadas as variantes tipo $1 \mathrm{de}$ receptores $\mu, \kappa$ e $\delta$. Esses receptores pertencem a superfamília com 7 domínios transmembrânicos acoplados à proteína Gi/o heterotrimérica (KIEFFER; EVANS, 2009; PAN et al., 2008; VAN RIJN; BRISSET; WHISTLER, 2010) e possuem a capacidade de formar interações receptor-receptor, formando complexos de receptores homômeros e heterômeros com propriedades farmacológicas diferentes (VAN RIJN; BRISSET; WHISTLER, 2010).

Em estudos dos efeitos pré e/ou perinatais de drogas, a dose a ser empregada não deve produzir efeitos tóxicos na mãe. De fato, o emprego de doses que levam ao aparecimento de sintomas acentuados de intoxicação não permite concluir se as possíveis alterações apresentadas pelos conceptos seriam devidas à ação embriotóxica da substância em estudo ou às alterações na homeostase materna (CARLOS, et al., 1996; LEMONICA, et al., 1996). Neste sentido, a presença da redução significativa no peso corporal materno, sinais clínicos da toxicidade ou de atividade são evidências suficientes de toxicidade materna e, invariavelmente, causam redução no peso corporal fetal e aumento no número de reabsorções (ou abortos), raramente observando-se morte fetal (KHERA, 1984).

O objetivo deste trabalho foi avaliar os efeitos da exposição materna durante períodos diferentes da gestação, sendo no primeiro terço no período do $2^{\circ}$ ao $6^{\circ}$ dias e no segundo terço do $11^{\circ}$ ao $15^{\circ}$ dias da administração de agonistas específicos ou não para receptores opióides, em alguns aspectos comportamentais nas mães e em suas proles, e em doses que não 
produzissem toxicidade materna e fetal. Neste caso, empregou-se a dose de $3,5 \mathrm{mg} / \mathrm{kg}$ s.c. de sulfato de morfina e solução salina a $0,9 \%$ para o grupo controle. Portanto, estas doses foram escolhidas para o presente estudo.

A avaliação do CM foi realizada primeiramente por meio do parâmetro de construção do ninho (Tabelas 1 e 2). Tanto os animais tratados com salina como aqueles tratados com sulfato de morfina apresentaram ninhos classificados como bons ou ótimos em praticamente todos os casos. A construção de ninhos remete a um tipo de comportamento, incluso no maternal, que independe da interação direta com os filhotes (BRIGDES, 1996). Evolutivamente, a construção de ninhos tem como finalidade garantir proteção e calor à ninhada, sendo que para tal a fêmea precisa ter capacidade de cavar, carrear materiais com a boca, bem como manipulá-lo tanto com a boca quanto com as patas (STERN, 1996). Assim, a alta porcentagem de animais construindo ninhos de qualidade ótima e boa neste experimento seria um indicativo de que o tratamento gestacional com agonistas opioidérgicos não inibiu significativamente o CM em ratas lactantes, pois segundo Numan (1994) a construção de ninhos demanda preservação da função motora, da motivação, da termorregulação e do CM.

Porém, em relação aos outros parâmetros relacionados ao $\mathrm{CM}$ foi possível verificar, conforme observado no Experimento 1, que aparentemente o desafio com morfina foi capaz de alterar o comportamento de recuperação, independente do pré - tratamento, assim como os resultados de Teodorov et al. (2008b) que demonstraram em seu trabalho que estes efeitos não foram observados nos animais pré-tratados, o que sugere a existência de tolerância induzida por morfina, como modulação de respostas mediadas por receptor opióide tipo $\kappa$ e que o tratamento agudo com o agonista especifico para esse receptor, U69593, leva a diminuição da atividade geral e aumento da latência de recuperação de filhotes em lactação, sugerindo que a estimulação aguda de receptores $\kappa$ pode ter importantes efeitos comportamentais durante a lactação.

Os efeitos opióides sobre o CM variam de acordo com a experiência reprodutiva Kinsley et al. (1988) e a idade, sendo que em ratas jovens o CM também é sensível a manipulações farmacológicas opioidérgicas (ZAIAS et al., 1996). A interrupção do tratamento crônico com morfina pode afetar os receptores opióides, estes são up-regulated pelo tratamento com morfina e gravidez e down-regulated durante a lactação em diferentes áreas do encéfalo (BABBINI e DAVIS, 1972; CRAIN et al., 1998; WISE; BOZARTH, 1999;). O presente trabalho enfatizou o tratamento com sulfato de morfina nos estágios inicial e médio da gestação, os resultados deste tipo de tratamento ainda não foram elucidados pela 
literatura atual que aborda as alterações comportamentais em mães tratadas no final da gestação. Em relação a isso Sukikara et al. (2011) demonstraram que a ativação induzida por opióides na PAG inibe o CM e estimula a expressão de comportamento de forrageamento e predatório (KINSLEY et al., 1990; MIRANDA-PAIVA et al., 2003). A expressão da interrupção deste comportamento é modulada pela estimulação opióide anterior ao final da gravidez (CRUZ et al., 2010). Sistemas opióides são plásticos e adaptativos e o tratamento com morfina de longo prazo pode também alterar a sensibilidade do CM. Embora o início do CM no parto em ratas primíparas é regulada pelos eventos endócrinos do final da gestação, a continuidade ou manutenção do comportamento pós-parto não está mais ligada à regulação hormonal (NUMAN; INSEL, 2003). Pesquisas indicam que uma vez que a fêmea parturiente interage com os seus filhotes, o encéfalo é modificado de modo a que os estímulos provenientes dos filhotes podem ativar o $\mathrm{CM}$ independentemente da influência dos ovários, dos hormônios placentários e pituitários (NUMAN; FLEMING; LEVY, 2006).

Tem sido sugerido que as modificações cerebrais subjacentes a este efeito podem incluir uma regulação negativa relativamente permanente dos circuitos neuronais e evitar uma regulação dos circuitos neurais subjacentes a atração da mãe pelos seus filhotes (NUMAN; INSEL, 2003). A APOM, localizada no hipotálamo rostral, é uma região crítica neural envolvida na regulação do $\mathrm{CM}$ em ratos e outras espécies, e tem sido demonstrado que alguns hormônios como o estradiol e a prolactina atuam sobre os neurônios na APOM estimulando o início imediato do CM após o parto BRIDGES et al. (1990, 1997).

Evidências atuais indicam que as projeções eferentes da APOM que ativam o sistema mesolímbico dopaminérgico são essenciais para a ocorrência de respostas maternas em direção aos filhotes, e um modelo detalhado neural tem sido apresentado (NUMAN; STOLZENBERG, 2009). Embora a APOM seja essencial para a ocorrência do CM, outros fatores operam em conjunto com os circuitos neurais nesta região. A principal entre esses fatores é a ocitocina, que é um hormônio lançado a partir da neuro-hipófise e um neurotransmissor/neuromodulador lançado em sinapses no encéfalo (NUMAN, 1994). Em uma revisão da função do hipotálamo, Swanson (1987) apresentou a evidência de um papel central do hipotálamo nos estados motivacionais básicos, tais como a ingestão de alimentos, reprodução e regulação de água e comportamento agressivo e defensivo. Estudos sugeriram um substrato neural do hipotálamo envolvido no controle de decisões comportamentais em face de sinais conflituosos (SUKIKARA et al., 2010). Consequentemente, as projeções da 
amígdala medial posterior, ativada por sinais de reprodução relacionados com o odor que convergem para o núcleo hipotalâmico, que funcionaria de uma "porta de controle" mecanismo de inibição dos comportamentos reprodutivos (CHOI et al., 2005).

A PAG foi comumente reconhecida como uma área importante na expressão dos comportamentos reprodutivos, bem como nas respostas defensivas (FANSELOW, 1991). Muitos trabalhos atualmente fazem uso de manipulação farmacológica com sulfato de morfina injetado central ou perifericamente, a fim de elucidar os mecanismos neurais que envolvem a expressão no CM, o uso da morfina nesse contexto se faz muito eficaz, uma vez que algumas regiões cerebrais envolvidas com manifestações comportamentais são muito ricas em receptores opioidérgicos.

Teodorov et al. (2011) afirmara, que tanto o número e a sensibilidade dos receptores de opióides mudam em função de gravidez e lactação, como comprovado em outros estudos (HAMMER; MATEO; BRIDGES, 1992; KINSLEY; BRIDGES, 1988). Outros autores demonstram que o número de receptores opióides hipotalâmicos aumenta durante a gravidez e é reduzido durante a lactação. A expressão de genes de receptores opióides centrais sofrem alterações durante a reprodução e em resposta aos desafios de morfina (BYRNES, 2008; TEODOROV et al., 2006). A transmissão opióide na PAG é relevante para a inibição do CM induzida por morfina (MIRANDA-PAIVA et al., 2002, 2003a, 2007). Os opiáceos tem efeito inibitório sobre o CM e é diminuído em fêmeas multíparas (KINSLEY; BRIDGES, 1988). Por outro lado, as concentrações de sítios de ligação de opiáceos e receptores de opiáceos são aumentadas tanto na APOM quanto no hipotálamo medial basal, duas regiões que se sabe serem importantes para o comportamento reprodutor e controlo neuroendócrino da pituitária, respectivamente (BYRNES, 2008).

Plasticidade na transmissão opioidérgica pode fornecer um substrato para a versatilidade e adaptações necessárias durante o período pós-parto para inibir o $\mathrm{CM}$ e estimular a procura de alimentos, por exemplo. A ação combinada dos hormônios esteróides, tais como o estradiol e a progesterona têm como resultados mudanças na interação dos opióides no encéfalo (BRIDGES; RONSHEIM, 1987). As concentrações séricas de hormônios do estresse, como a corticosterona e prolactina podem ser influenciadas por opióides (MANN; BRIDGES, 1992; SAGRILLO; VOOGT, 1991). Ambos corticosterona e prolactina são geralmente relevantes para comportamentos reprodutivos e particularmente importante para induzir o CM (COMMOLI; RIBEIRO-BARBOSA; CANTERAS; 2003; DE 
OLIVEIRA et al., 2007). Da mesma forma, os níveis séricos de estradiol e progesterona podem ser afetados pela estimulação opióide (FISHER et al., 2009).

Opióides estimulam liberação de prolactina, um hormônio conhecido por facilitar o CM (MANN; BRIDGES, 1992; SAGRILlO; VOOGT, 1991). A influência de opióides no CM pode ser tanto direta quanto indireta (BRIDGES; RONSHEIM, 1987). Mudanças nessas moléculas endógenas influenciam a sensibilidade do sistema sensorial. Isto é particularmente verdadeiro no que diz respeito às estímulos olfativos (DE OLIVEIRA et al., 2007), a prolactina também está relacionada a modulação da ejeção de leite (SMART; DOBBING, 1971).

Nos resultados desse trabalho, pode ser observada uma alteração no ganho de peso das ninhadas femininas e masculinas de mães tratadas com morfina no primeiro ou segundo terços da gestação e desafiadas com morfina comparadas com o grupo controle, conforme demonstrado no Experimento 2.

Em linhas gerais, nem o tratamento prévio nem o desafio influenciou o ganho de peso das ninhadas até o desmame, indo contra trabalhos que demonstraram que o uso de agonista opioidérgico (naloxona), tem um impacto significativo sobre o curso do desmame e desenvolvimento, apoiando as conclusões anteriores de que as interações dos opióides endógenos com seus receptores desempenham um papel crucial no crescimento dos filhotes (ZAGON; MCLAUGHLIN, 1989).Tendo em vista que a inibição da ocitocina promove a diminuição de ejeção de leite e a diminuição da prolactina altera os estímulos sensoriais da lactante, promovendo uma privação nutricional e nos cuidados com sua prole (SMART; DOBBING, 1971). Porém nas ninhadas com idades entre 45 e 60 dias de vida pôde ser observado uma alteração significativa no ganho de peso, o que pode mostrar algum tipo de relação com o sistema de receptores de melanocortinas. Segundo Rodrigues (2003) o peso corporal é regulado por uma interação complexa entre hormônios e neuropeptídeos, sob o controle principal de núcleos hipotalâmicos. As melanocortinas não neuropeptídios derivados da poliproteína pró-opiomelanocortina (POMC), expressa no núcleo arqueado do hipotálamo, núcleo do trato solitário, hipófise e outros tecidos periféricos (GEE, et al., 1983; JACOBOWITZ; O'DONOHUE, 1978). O sistema das melanocortinas engloba ainda dois antagonistas endógenos, Agouti e a Proteína Relacionada com a Agouti (AgRP) (LU; WILLARD; PATEL, 1994; OLLMANN; WILSON; YANG, 1997). Em nível celular esses neuropeptideos são reconhecidos por cinco tipos de receptores do tipo GPCR (MCRs) que são 
classificados de 1 até 5 (MC1R - MC5R). Estes receptores diferem entre si na distribuição tecidual e na afinidade de ligação aos diferentes tipos de melanocortinas e antagonistas.

Dentre os cinco tipos de melanocortinas descritos os do tipo MC3R e MC4R estão intimamente relacionados a homeostase energética. O MC3R é predominantemente expresso no SNC e parece apresentar um papel importante na homeostase energética uma vez que camundongos knockout para MC3R desenvolvem uma síndrome metabólica leve, com aumento da massa gorda, hipofagia e hipoatividade (BUTLER; KESTERSON; KHONG, 2000; CHEN; MARSH; TRUMBAUER, 2000). Este receptor parece ter um papel duplo na regulação da homeostasia energética pois atua como autoinibidor em neurônios hipotalâmicos que também sintetizam a POMC (COWLEY; SMART; RUBINSTEIN, 2001). Já o MC4R é vastamente expresso no SNC, predominantemente no hipotálamo, hipocampo, tálamo e medula espinhal (MOUNTJOY; WILD, 1998). O envolvimento direto do MC4R na regulação da homeostasia energética (TAO, 2010) é demonstrado pelo fenótipo de obesidade de ratos knockout para o gene que codifica para esse receptor (HUSZAR; LYNCH; FAIRCHILDHUNTRESS, 1997).

O AgRP é um antagonista competitivo para os receptores de melanocortina MC3R e MC4R no SNC e é fortemente co-localizado com o neuropeptideo Y (NPY), cujo os efeitos dependem da atividade dos receptores opioidérgicos (HAGAN, et al., 2001). Segundo Hagan (2001) os receptores opióides podem desempenhar um papel critico na mediação dos efeitos do AgRP sobre a ingestão de alimentos, e tem sido proposto que esse envolvimento dos opióides estariam relacionados não apenas na ingestão calórica, mas também em aspectos de escolha dos alimentos (ALVARO, et al., 1996)

Os trabalhos que tratam sobre essa relação entre os sistema opioidérgico, consumo de alimentos e obesidade já se fazem bem estabelecidos, o que poderia elucidar de alguma forma os resultados encontrados nesse trabalho, mostrando as alterações encontradas no ganho de peso das ninhadas das proles de mães tratadas com sulfato de morfina durante a gestação, uma vez que a morfina é um fármaco capaz de atravessar a barreira placentária, poderia interferir de alguma forma na modulação desse sistema que engloba os receptores de melanocortinas, AgRP, NPY e receptores opióides.

Numerosos experimentos demonstraram que a experiência no início da vida influencia o desenvolvimento de filhotes. Várias características, originalmente descritas como hereditárias, podem ter origem durante o período precoce pós-natal (FRANKOVÁ, 1985). Assim, qualquer tratamento experimental materno pode causar efeitos pós-natais mediados diretamente via 
leite ou indiretamente por meio da negligência materna no cuidado com as ninhadas, ou alterações no comportamento da mãe podem produzir alterações no desenvolvimento físico da prole (SMART; DOBBING, 1971).

Durante a ontogenia, o sistema nervoso central passa por uma rápida proliferação celular, diferenciação e crescimento, sendo particularmente sensível a alterações induzidas pelo meioambiente. Nesse sentido, o desenvolvimento físico do encéfalo de ratos pode ser consideravelmente afetado por subnutrição durante o período de amamentação. Ratos mal alimentados durante a lactação apresentaram redução no número de células, na concentração de colesterol e no tamanho cerebral. Portanto, é razoável supor que condições de privação nutricional também interfiram com o desenvolvimento neurológico tais como aqueles expressos pela ontogenia de reflexos e simples padrões de comportamento (SMART; DOBBING, 1971). Portanto a avaliação do desenvolvimento ponderal de animais em desenvolvimento assume importância inquestionável

A distância ano-genital (DAG) no rato depende basicamente da presença de testosterona no final da gestação. Assim, ratas androgenizadas apresentam distâncias maiores que ratas normais. Ratos tratados pré-natalmente com fenobarbital apresentam várias disfunções reprodutivas, entre elas, redução da DAG (GUPTA; SHAPIRO; YAFFE, 1980). Mais ainda, existe correlação entre a mesma na infância com o tamanho dos núcleos sexualmente dimórficos do hipotálamo na idade adulta, tendo sido aventado que alterações nesta medida podem ser preditivas de interferências na determinação sexual do encéfalo (FABER; HUGHES, 1992). Além disto, outros fatores tais como o estresse, fator de crescimento epidérmico e mesmo drogas interferem com a DAG (GUPTA; SIEGEL; ELLIS, 1991; MCCOY; SHIRLEY, 1992; VARMA; BLOCH, 1987). Existem evidências mostrando que drogas GABAérgicas podem modificar este parâmetro (GUPTA; SHAPIRO; YAFFE, 1980). Neste trabalho não foram observadas diferenças na DAG das proles feminina e masculina quando comparados aos respectivos grupos controles. Também não foram observadas diferenças significantes nos demais parâmetros de desenvolvimento físico das proles feminina e masculina, excetuando-se os parâmetros abertura da rima vaginal e descida dos testículos, conforme visto no Experimento 3.

Segundo Teodorov, (2006) o meio ambiente hormonal, durante o desenvolvimento fetal, determina muitos aspectos da sexualidade adulta relacionados aos processos de diferenciação sexual, bem como a estrutura dos órgãos sexuais. E é este ambiente crítico que determina, em última instância, a intensidade em que diferentes padrões comportamentais são expressos em 
ratos e ratas (HERNÁNDEZ-TRISTÁN; AREVALO; CANALS, 1999). Assim, eventos ocorridos no período crítico podem afetar a definição sexual e o esquema organizacional do encéfalo que, na idade adulta, resultarão em padrões apropriados de secreção de gonadotrofinas e certos tipos de comportamentos ligados ao sexo (LEONARD, 1982). A importância da complexidade desses eventos deve-se ao fato de estes não serem essenciais somente à sobrevida do animal, mas sim à perpetuação da espécie. No rato, a diferenciação sexual origina-se desse padrão (defeminização ou masculinização), ocorrendo como resultado da secreção de testosterona pelos testículos. Sabe-se que os ratos alcançam o número de neurônios que terão na vida adulta no $15^{\circ}$ dia de vida, enquanto em ratas esse número é alcançado de modo bifásico: diminuição do número de neurônios durante a primeira semana de vida, aumento dos neurônios de modo que as diferenças sexuais desapareçam no $15^{\circ}$ dia e, finalmente, perda dos neurônios ao final deste mesmo dia (SEGOVIA et al., 1999).

Estudos demonstraram também que, no rato, um dos fatores cruciais para a masculinização do hipotálamo parece ser o leite materno (KACSÓH et al., 1986), já que este possui grandes quantidades de $\mathrm{GnRH}$, o qual desencadeia a liberação de testosterona pelos testículos do filhote no período pós-natal de masculinização hipotalâmica. Além disso, substâncias liberadas no leite (como medicamentos ou seus metabólitos) poderiam promover alterações no desenvolvimento dos animais e também no homem, já que no período de amamentação estes ainda estão em desenvolvimento e muitos de seus sistemas, ainda imaturos. Na amamentação, o GnRH, quando liberado, alcança a hipófise do recém-nascido, induzindo a secreção de gonadotrofinas com padrões diferenciados entre machos e fêmeas. No rato, atua desencadeando a masculinização e, na rata, atua evitando a defeminização hipotalâmica pela inibição da resposta do ovário infantil às gonadotrofinas durante o aleitamento.

O desenvolvimento puberal que é a última fase de um processo contínuo de mudanças moduladas pro atividades hormonais, faz parte de um processo de maturação do eixo hipotalâmico-hipofisário-gonadal, resultando em crescimento e desenvolvimento dos órgãos genitais e concomitantemente, de mudanças físicas e psicológicas que conduzem a capacidade de reprodução e perpetuação da espécie (SALVATORI, et al., 2004). Em ratas, o único sinal externo do evento final de maturidade sexual, é a abertura do canal vaginal que é dependente da estimulação causada pelo estrógeno proveniente da atividade do eixo hipotalâmicohipofisário-gonadal (SISK, et al., 2001). Em ratos a maturação sexual é resultado de 
interações complexas no mesmo eixo cujo o ápice se mostra na ocorrência da descida dos testículos.

Os resultados deste trabalho mostraram que o desenvolvimento físico das proles como um todo não sofreu alterações devido ao tratamento, porém o desenvolvimento dos órgãos sexuais apresentaram diferenças significantes tanto em machos quanto em fêmeas podendo terem sido causados tanto por alterações maternas quanto por ação da própria morfina no desenvolvimento do eixo hipotalâmico-hipofisário-gonadal visto que o desenvolvimento e maturação dos órgãos sexuais é regulado por ação hormonal modulada por este eixo.

Em relação ao parâmetros de desenvolvimento neurocomportamental observados neste trabalho, de acordo com Altman e Sudarshan (1975), três sistemas periféricos estão envolvidos no controle do ajuste postural que incluem o sistema vestibular, estereoceptivo (por exemplo o táctil) e o sistema proprioceptivo. A medida da função do sistema vestibular ao nascer é alterada pela imaturidade do sistema motor. $\mathrm{O}$ reflexo de endireitamento e o dia de andar adulto refletem o desenvolvimento do sistema motor e a atividade do sistema vestibular (ALTMAN; SUDARSHAN, 1975). No presente trabalho a ausência de alterações nestes parâmetros indicou que o tratamento gestacional com agonista opióidergico não interferiu com o desenvolvimento neurocomportamental dos animais, conforme observado no Experimento 4. Assim a exposição gestacional materna ao sulfato de morfina não foi capaz de modificar os parâmetros neurcomportamentais nos animais e estes dados em conjunto com aqueles obtidos no dia de andar adulto e no reflexo de endireitamento, mostram ausência de alterações no desenvolvimento motor dos animais expostos pré-natalmente à droga.

Diante de resultados comportamentais e de desenvolvimento apresentados até o momento, restou a segunda parte deste projeto no qual se pretendeu avaliar se haveria alguma intersecção entre os resultados anteriores com algum tipo de alteração molecular, estritamente dos receptores opióides, em regiões que sabidamente estão envolvidas nos aspectos reprodutivos e motores em ratos, sendo estriado, hipotálamo e PAG, esta última escolhida devido a numerosos resultados encontrados em nosso laboratório advindo de outros projetos em andamento. Antes de discutir os resultados obtidos em relação a biologia molecular de mães e filhotes que foram tratados com agonistas opioidérgicos, seria interessante relembrar as principais características inerentes a cada subtipo de receptor opióide estudado. Brownstein, (1993) mostraram que existem locais estereoespecíficos em todo o SNC em 
roedores, sem uma distribuição uniforme o que explica o porque este projeto ter escolhido 3 regiões encefálicas diferentes para comparação em nosso estudo.

O receptor opióide tipo $\mu$ é amplamente distribuído pelo encéfalo, sendo que sua distribuição varia muito de acordo com a espécie estudada e os ligantes endógenos preferencialmente são as endorfinas. Em roedores ocorre densidade moderada na PAG e núcleo da rafe (MANSOUR et al., 1995). Mann; Kinsley; Bridges, (1991) observaram que injeção de DAMGO, i.c.v. em ratas lactantes foi capaz de alterar o comportamento maternal de maneira dose-dependente. Estudos moleculares aliados à farmacologia revelaram que existem diferenças na resposta a drogas de acordo com a variante do receptor tipo um que é ativada, sendo que sete novas variações do exon 11 (resultantes de splicing alternativos) do gene Oprml foram identificadas (PASTERNAK, 2010).

Os receptores do subtipo $\mu 1$ são caracterizados por sua alta afinidade para naloxonazina, por ligação irreversível, e muitas drogas opióides, incluindo morfina e DAMGO, sugerindo que esteja envolvido em muitos efeitos como analgesia supraespinal, sedação, euforia, miose, liberação de prolactina, diminuição do turnover de acetilcolina e indução de catalepsia (PASTERNAK; WOOD, 1986; PASTERNAK, 1988, ZHI-PING et al., 2012).

Os receptores tipo $\kappa$, sítios preferenciais para ligação de dinorfinas, têm papel importante na imunidade, percepção dolorosa, fisiológica neuroendócrina, comportamento afetivo e aspectos cognitivos, podendo também modular o comportamento reprodutivo em fêmeas (TEODOROV et al., 2008). O receptor opióide do tipo $\kappa$ possui alta afinidade por dinorfina A, um agonista endógeno, e por U50,488 e U69593; porém, não há ligação com agonista $\mu 1$-seletivo DAMGO ou com o agonista $\delta 1$-seletivo DPLPE. U69593 se liga seletivamente ao subtipo $\kappa 1$, e ainda não existe um agonista seletivo para $\kappa 2$ e $\kappa 3$ (CLARK; LEVENSON; MEDZIHRADSKY, 1989).

Finalmente os receptores tipo $\delta$ são alvos preferenciais de ligação para encefalinas e estudos mostram que parecem ter maior importância na periferia, embora possam também contribuir para analgesia central. A ativação desses receptores pelo tratamento com DADL aumentou os níveis de $\mathrm{GABA}_{\mathrm{A}}$ em neurônios do córtex de ratos em desenvolvimento (QIU et al., 2011). O receptor opióide do tipo $\delta$ possui alta afinidade por DADLE e pelos agonistas seletivos DPLPE e DPDPE, mas não pelo agonista $\mu 1$-seletivo DAMGO ou pelos agonistas $\kappa$ seletivos U50,488 e U69593. Estudos comportamentais e de binding sugerem a existência de subtipos de receptores $\delta$ (PORTOGHESE et al., 1992, 1993). 
Alterações adaptativas nos neurônios são consequência do tratamento prolongado com morfina e geralmente são relacionados com alterações comportamentais combinadas à dependência e a síndrome de abstinência. Entretanto, os mecanismos moleculares e celulares envolvidos nessas alterações em longo prazo ainda não são totalmente esclarecidos, motivo pelo qual delineamos nossos experimentos nesse projeto. Alguns estudos utilizando-se de ferramentas de genômica e proteômica estão tentando identificar essas alterações nos genes e nos conteúdos proteicos no encéfalo de ratos que podem, inclusive, estar associada aos processos de vicio a morfina (AMMON-TREIBER; HÖLLT, 2005; BIERCZYNSKAKRZYSIK et al., 2006; HEMBY, 2004; MCCLUNG; NESTLER; ZACHARIOU, 2005). Justamente pelo fato dessas drogas alterarem a transcrição gênica no encéfalo e coluna espinal após tratamentos agudo e prolongado é que chamou a atenção se seus efeitos poderiam durar o suficiente para atingir as proles quando avaliadas na idade adulta, já que estudo mostra que a alteração genica devido à exposição a opióides é a responsável por alterações comportamentais na idade adulta, bem como aumento da probabilidade de vicio.

Estudos com roedores têm demonstrado que o tratamento crônico com opióides tem como consequência o desenvolvimento de tolerância a seus efeitos farmacológicos. Assim, a dependência física ocorre e caso a droga seja retirada é possível observar ocorrência de síndrome de abstinência (BHARGAVA, 1991). Os opióides produzem seus efeitos atuando basicamente em três tipos de receptores opióides, denominados de $\mu, \delta$ e $\kappa$. Aspectos qualitativos e quantitativos dos sintomas relacionados a fenômenos de tolerância e dependência, bem como a síndrome de abstinência observada após tratamento prolongado e que atuem de maneira diferenciada nesses três tipos de receptores parecem também modular aspectos fisiológicos distintos, embora pertençam a uma mesma via de sinalização, particularmente e a nociceptivo.

No Resultado 1 do Experimento 5, no qual mães foram tratadas com agonistas para receptores opióides no primeiro terço da gestação, não foram observadas diferenças significantes tanto na expressão gênica quanto nos produtos protéicos. Esses achados podem ser explicados pelo fato de se tratar de um tratamento muito precoce, do $2^{\circ}$ ao $6^{\circ}$ dias de gestação e cujo período transcorrido até o momento das análises moleculares tenha sido demasiadamente longo. Possivelmente o tratamento até possa ter alterado alguns padrões moleculares pelo fato da ligação das drogas aos receptores e então desencadeando uma série de respostas no organismo, porém os mesmo não foram prolongados a ponto de serem detectados no futuro. Corrobora com esses resultados os dados encontrados nos Resultados 2 
e 3 do Experimento 5, respectivamente os dados moleculares das proles feminina e masculina cujas mães foram tratadas no primeiro terço da gestação. Também não foram encontradas alterações visto que provavelmente o tempo transcorrido entre o tratamento e as avalições moleculares tenha sido extenso e as proles foram avaliadas somente aos 60 dias de idade.

Sabe-se que os analgésicos opióides são os mais utilizados para tratamento de dor de moderada a severa. Por outro lado, o tratamento prolongado pode induzir dependência, e esta é a principal limitação de um uso mais amplo na clínica médica. A dependência a opióides costuma estar associada a ativação de receptores opióides tipo $\mu$ (ZELEK-MOLIK et al., 2010; WANG et al., 1999) porém a morfina também induz adaptações no sistema opióidergico mediado pelo receptores tipo $\kappa$. Estudos têm mostrado que a desregulação do sistema opióidergico $\kappa$-mediado também é consequência do tratamento prolongado com morfina e responsável pela dependência (YU; YAN; GONG, 2012).

Existe uma série de estudos que mostram que o tratamento com morfina pode alterar a expressão gênica em diferentes áreas do encéfalo de roedores, inclusive com uma única injeção. Administração aguda de morfina induz modificações na expressão dos genes envolvidos em processos tão diversos como a transdução de sinal acoplada aos receptores opióides (FAN et al., 2002, 2003; KAEWSUK et al., 2001) fatores de transcrição (Kelz et al., 1999) e proteínas de ligação aos cálcio (TIRUMALAI; HOWELLS, 1994). Ainda, a morfina tem mostrado ser capaz de induzir alterações neuronais que persistem por um longo período após a retirada da droga, mas seu efeitos moleculares ainda não estão totalmente elucidados (NESTLER; AGHAJANIAN, 1997).

No Resultado 1 do Experimento 5 avaliou-se os padrões moleculares de mães que sofreram tratamento com agonistas seletivos ou não para os receptores opióides no segundo terço da gestação. Diferentemente do que foi observado com mães tratadas no primeiro da gestação, as quais não apresentaram nenhuma alteração molecular, esses animais apresentaram aumento na expressão de Oprk1 (no estriado e hipotálamo) e de Oprm1 (somente no estriado), além de aumento do conteúdo proteico KOR no estriado. Uma série de trabalhos têm mostrado que o tratamento prolongado com morfina altera a expressão de proteínas envolvidas na neurotransmissão, sinalização, metabolismo energético e degradação proteica (LI et al., 2006; MORÓN; DEVI, 2007; NEASTA et al., 2006). Estudo conduzido por Quan et al. (2009) mostrou que o tratamento prolongado com morfina em machos promoveu alterações na atividade e /ou expressão dos proteassomas, responsáveis pela 
degradação e reciclagem de proteínas incluindo receptores opioidérgicos. Porém, esses mesmos autores não descartam a possibilidade de que outras proteínas importantes como o CREB e os próprios receptores opióides possam não ter sido identificados por estarem em níveis muito baixos.

Décadas de pesquisa têm focado em estudos para compreensão dos mecanismos moleculares responsáveis pelos efeitos do uso de drogas como a morfina a longo-prazo, o que auxilia no desenvolvimento de analgésicos mais eficientes e seguros para o tratamento de dores crônicas (PROKAI et al., 2005). A tolerância e a dependência são respostas fisiológicas complexas que envolvem a adaptação em muitos níveis do SNC bem como em tecidos periféricos. Entretanto, muitas destas adaptações são eliciadas pela ativação de receptores opioidérgicos por ação da morfina (MARTINI; WHISTLER, 2007). Os receptores opióides são expressos na membrana celular e convertem as mensagens de ligantes extracelulares em sinais intracelulares. A magnitude da transdução de sinal de um complexo "receptor-ligante" é controlada por muitos fatores que incluem propriedades do próprio ligante como afinidade, potência, eficácia, biodisponibilidade e tempo de meia-vida. Juntos, esses fatores constituem a chamada atividade relativa (MARTINI; WHISTLER, 2007). Ainda, a magnitude da sinalização através do receptor-ligante também parece ser controlada pelo tempo no qual o receptor opióide permanece acoplado à proteína $\mathrm{G}$ e pode ser regulada pelo nível de desensibilização e por processos de endocitose.

Muitas proteínas quinases se mostram implicadas na desensibilização dos receptores opióides mediada por ligantes, como a proteína quinase $\mathrm{C}$ (PKC), proteína quinase A (PKA), tirosina quinase e proteína $\mathrm{G}$ ligada a receptor quinase (GRKs). Os receptores fosforilados pela GRK recrutam beta-arrestinas e essa ação possui múltiplas funções como desacoplamento do receptor da proteína $G$, padrões de transdução de sinal e facilitação de processos de endocitose dos receptores (ou tolerância). Interessante notar que receptores fosforilados pela PKC tornam-se resistentes aos processos de endocitose/tolerância.

Estudos mostram que a desensibilização dos receptores opioidérgicos, particularmente do tipo $\mu$, ocorre rapidamente após administrações repetidas de doses analgésicas, ou ainda, após uma dose aguda de morfina (GÁRZON et al., 2002). Os receptores opióides, quando ligados a drogas agonistas, são inativados por proteínas $G$ regulatórias. Esta inativação envolve proteína $\mathrm{G}$ ligada a receptor quinase (GRK) que fosforila resíduos de serina/treonina no receptor. Esta modificação capacita as $\beta$-arrestinas de se ligarem a estes resíduos, levando aos processos de endocitose (SHENOY; LEFKOWITZ, 2005). Estes achados poderiam 
explicar o aumento nos níveis de expressão gênica de Oprk1 e Oprm1 bem como o aumento no conteúdo de KOR, já que os dados parecem levar para a hipótese de que o receptor $\kappa$ é o mais requerido quando de avaliações que envolvem desenvolvimento animal e processos reprodutivos. Estudos em nosso laboratório mostraram que ocorre aumento de Oprm1 mas não em Oprk1 quando ratas são avaliadas quanto ao comportamento sexual (dados ainda não publicados).

No Resultado 1 do Experimento 5 avaliou-se a expressão dos genes que codificam para receptores opióides e seus respectivos conteúdos proteicos no estriado, hipotálamo e PAG de ratas que receberam o tratamento com agonistas para os receptores opióides no primeiro da gestação e depois foram desafiadas ao $5^{\circ}$ dia de lactação com a mesma droga. Esses animais primeiramente foram avaliados quanto ao $\mathrm{CM}$ e depois foram decapitadas e seus encéfalos retirados para asa análises moleculares. Os resultados mostraram que houve aumento de Oprk1 e Oprml de maneira diferenciada. Oprk1 mostrou-se aumentado no estriado e hipotálamo em tratamentos com morfina e U69593, enquanto que Oprm1 mostrouse elevado nas 3 regiões estudadas com o tratamento com morfina e somente no estriado e hipotálamo quando o tratamento foi com DAMGO.

Esses achados revelam que de fato os tratamentos com morfina, U69593 e DAMGO promoveram aumento na transcrição de RNAms de Oprk1 e também em Oprm1 justamente pelo fato de ser 1.000 vezes mais afim para esse tipo de receptor (tipo $\mu$ ), bem como a potencialização de ativação da transcrição pelos agonistas seletivos. Como na PAG a densidade de receptores tipo $\mu$ é muito alta talvez o tratamento com DAMGO tenha capacidade de modular os processos moleculares e assim ativar a transcrição para que haja mais sítios de ligação inclusive para ligantes endógenos que sabidamente são liberados quando ocorre o CM (MANSOUR et al., 1994), fato que não foi observado para U69593. Ainda, o fato de não ser encontrada nenhuma alteração nos conteúdo protéicos reforça que o período de tratamento no primeiro terço da gestação provavelmente envolva um cenário de profundas modificações no organismo materno e assim não atingiu limiar tal a ponto de promover alterações moleculares significantes.

Ligantes opióides endógenos, as encefalinas e endorfinas, possuem grande potência e eficácia na formação de complexos com os receptores, porém são induzidos os processos de endocitose e desensibilização. Não está ainda bem esclarecido como a maquinaria de endocitose funcionaria, mas estudos mostram que possivelmente certa quantidade de 
subunidades G $\beta \gamma$ ser liberada das proteínas Gai para efetivamente recrutar os processos de endocitose.

Assim, cada vez que uma droga opióide é utilizada, muitas propriedades de receptoresligantes parecem ser alteradas. Cada uma dessas propriedades tem uma contribuição diferente para atingir o sinal transmitido para a célula, com ligantes endógenos, presumivelmente proporcionando um equilíbrio de cada um dos componentes. Ainda não é claro como a morfina não promove a completa desensibilização do receptor, bem como a retirada desta droga causa sinais de dependência, uma clara identificação de que a transdução de sinal do receptor está acontecendo na presença da droga. Além disso, é pouco compreendido como a morfina induz forte tolerância, já que a mesma falha em promover significantes processos de internalização de receptores (HABERSTOCK-DEBIC et al., 2003; RANG et al., 2007).

Essa internalização de receptores poderia ser compreendida pelo organismo do animal, que já se encontra alterado pela administração da droga, como um fator potencialmente ativador da transcrição de genes que codificam para esses receptores. Esses conceitos poderiam explicar os resultados do Resultado 1 do Experimento 5, no qual mães que foram tratadas no segundo terço da gestação e desafiadas ao $5^{\circ}$ dia de lactação mostraram aumento de expressão de Oprk1 e Oprm1 provavelmente pelo fato de ocorrer uma sensibilização opióidergica pelo tratamento e que foi ainda mais evidenciado quando da dose desafio. Ainda, o aumento de KOR no estriado revela mais uma vez a importância da sinalização opióidergica via receptor tipo $\kappa$ em comportamentos reprodutivos, particularmente no estriado o qual é fundamental para que ocorra controle motor adequado que viabiliza o $\mathrm{CM}$, juntamente com o sistema dopaminérgico (Resultado 2 do Experimento 5). O aumento de MOR no hipotálamo reforça ainda mais o papel motivador para realização do CM por parte da fêmea, já que a realização desse comportamento libera muitas endorfinas que têm como alvo o receptor tipo $\mu$.

Manifestações patológicas da exposição pré-natal a opióides, incluindo prejuízos fisiológicos e psicológicos, têm sido descritos (KUHN et al., 1992). Os receptores opióides em desenvolvimento pode prontamente sofrer essas alterações após a exposição a opiáceos. A seguir serão discutidos os resultados obtidos para os estudos que avaliaram as proles femininas (Resultado 2 do Experimento 5) e masculinas (Resultado 3 do Experimento 5) cujas mães foram tratadas no segundo terço da gestação com agonistas opióidergicos. 
No Resultado 2 do Experimento 5, no qual a prole feminina apresentou aumento de Oprk1 no estriado e PAG concomitante a diminuição de KOR na PAG, bem como diminuição de Oprm1 e MOR na PAG. A mesma explicação pode ser aplicada no Resultado 3 do Experimento 5 observou-se aumento da expressão de Oprk1 no hipotálamo e PAG concomitante a diminuição de Oprm1 nas 3 regiões estudadas e também diminuição de MOR no hipotálamo. Esses animais foram avaliados aos 60 dias de idade e provavelmente o tratamento no segundo terço da gestação foi fundamental para a modificação permanente da circuitaria opióidergica.

Em estudo conduzido por Yu et al., (2012), no qual os autores trataram ratos aguda e cronicamente ( 8 dias consecutivos) com morfina $(8,0 \mathrm{mg} / \mathrm{kg}$, ip) e posteriormente avaliaram os níveis de RNAm para o receptor tipo $\kappa$, demonstrou que as alterações na expressão de $\kappa$ possivelmente foram devidas a uma adaptação neuronal especifica aos efeitos fisiológicos da morfina e que são bem diferentes dos efeitos observados nos processos de tolerância e dependência. Nesse estudo o tratamento agudo aumentou o RNAm em estruturas como corte pré-frontal medial, núcleo de accumbens e área tegmental ventral, enquanto que o tratamento prolongado somente aumentou a expressão no córtex diminuindo nas outras duas regiões. Isso evidenciou respostas diferenciadas do sistema opióidergico $\kappa$-mediado em estruturas mesocorticolímbicas em machos. Por outro lado, em estudo conduzido por Bals-Kubik et al., (1993) mostram que a administração sistêmica de agonistas para receptor tipo $\mu$ induzem preferência por lugar enquanto que o tratamento utilizando-se agonistas para receptores $\kappa$ promovem aversão ao lugar. Além disso, a ativação do receptor tipo $\kappa$ parece estar envolvida na modulação da transmissão glutamatergica (MARGOLIS et al., 2005).

Também é conhecido que o tratamento crônico com morfina produz um up-regulation compensatório dos níveis de AMPc, superexpressando-o em várias regiões cerebrais como locus coeruleus, VTA, núcleo accumbens e amígdala (AVIDOR-REISS et al., 1996; BONCI; WILLIAMS, 1997; NESTLER, 1996; TERWILLIGER et al., 1991). Alterações celulares que ocorrem durante a superativação de AMPc incluem aumento da expressão de certas adenilil ciclases, PKA e CREB (Nestler, 2001) e que a endocitose dos receptores pode reduzir este upregulation compensatório (FINN; WHISTLER, 2001). Essa poderia ser uma explicação para a diminuição no conteúdo de MOR observado nas proles masculina e feminina.

Finalmente, mais recentemente pesquisadores tem demostrado o "trafego" de receptores (Von Zastrow, 2010) e sugerido um papel para heterodímeros formados pelos receptores $\mu / \delta$ (Gupta et al., 2010), o que poderia em partes explicar o porque de nenhum dos 
experimentos ter apresentado alterações na expressão de $\operatorname{Oprd} 1$ e no conteúdo de DOR nas 3 regiões encefálicas avaliadas. Esses mecanismos diferenciados parecem não ser excludentes e provavelmente devem contribuir para respostas tão diferenciadas entre machos e fêmeas. A importância do receptor tipo $\delta$ foi confirmada em estudos com camundongos nocauteados para receptor $\delta$ e em modelos de downregulation antisense que também revelaram uma perda da tolerância à morfina (HE et al., 2011).

Esses dados em relação à atividade dos receptores $\mu, \kappa$ e $\delta$ necessitam de confirmação por meio de histoquímica de fluorescência, na qual se pode detectar se a proteína formadora do receptor opióide de fato foi codificada ou ainda, se está efetivamente posicionada na membrana da célula onde de fato seria ativada pela ligação com os agonistas. Isso se deve ao fato de não ser possível uma concordância entre ativação da transcrição, aumento dos níveis proteicos e posicionamento do receptor (proteína) em sua interface de ligação a drogas ou ligantes endógenos pois os estudos moleculares envolvem um pool da molécula de interesse em termos bioquímicos e não funcionais. 


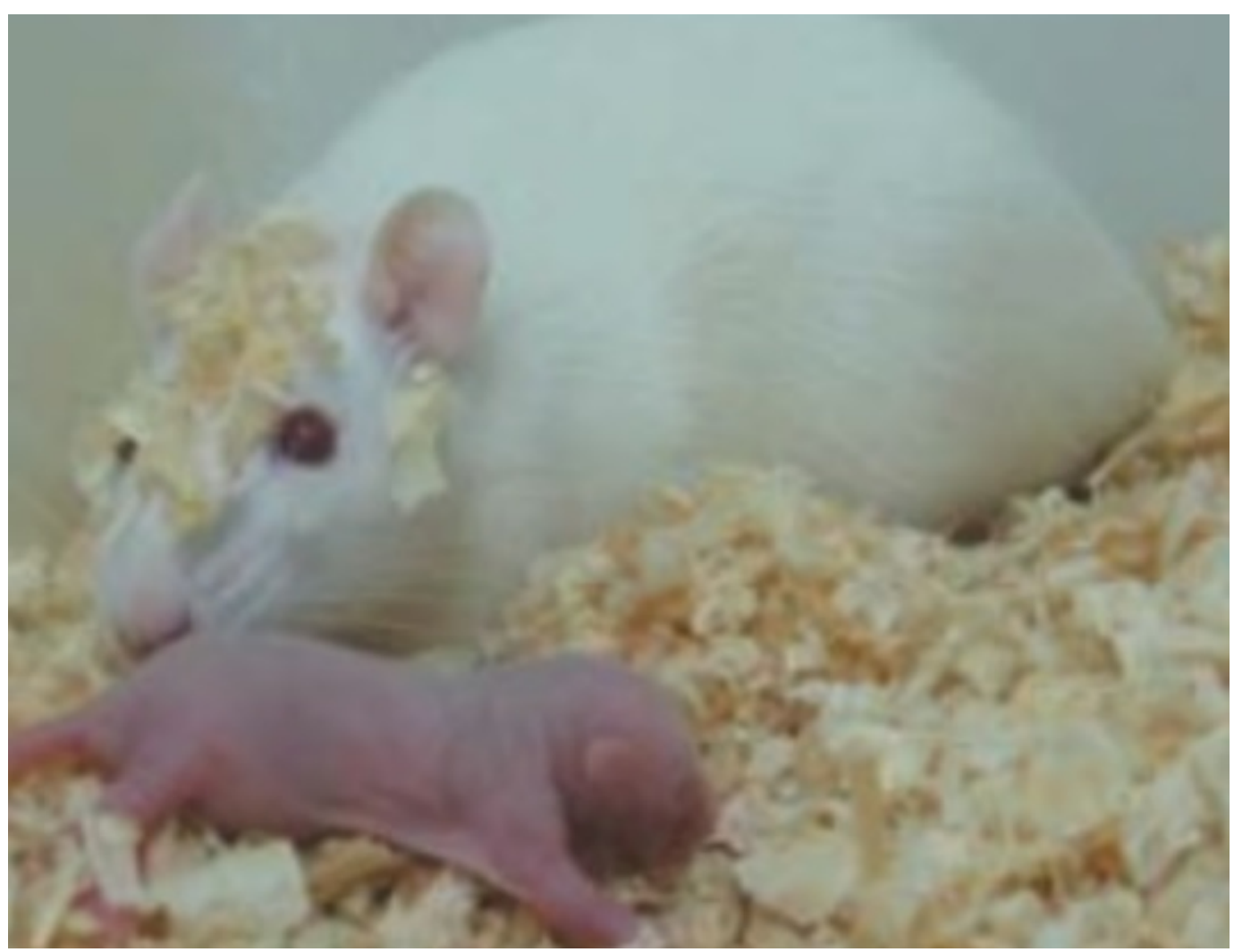

6 CONCLUSÃO 
O tratamento com morfina no primeiro e segundo terços da gestação de ratas:

- Alterou parâmetros do comportamento maternal;

- Alterou parâmetros do desenvolvimento físico e neurocomportamental em ambas as proles;

- Alterou os padrões de expressão gênica e produtos protéicos nas mães e em suas proles nas regiões encefálicas de interesse.

- Pode culminar em alterações a longo prazo em ambas as proles, tanto em termos fisiológicos quanto comportamentais, que somente poderão ser observados na idade adulta. 


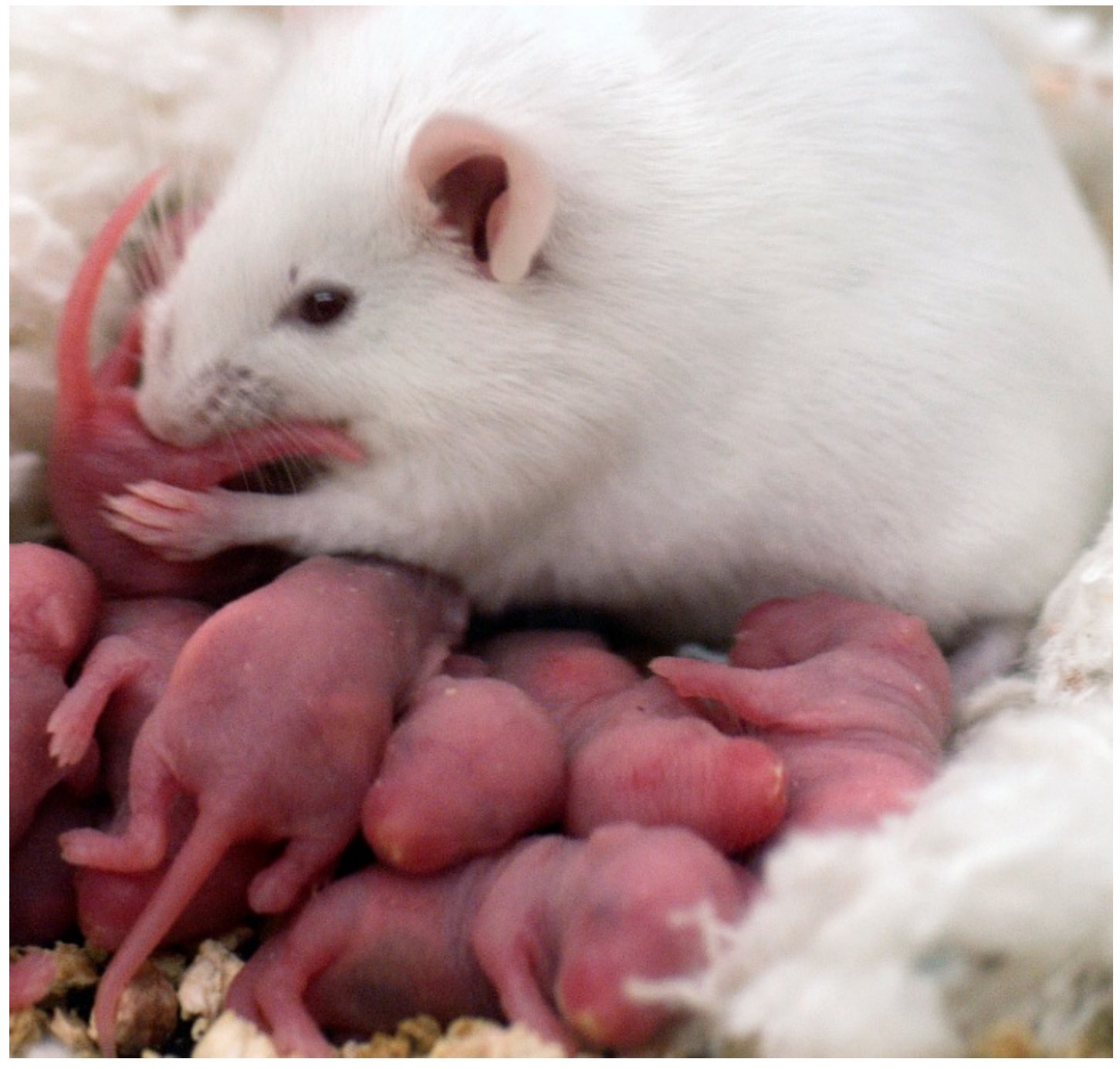

REFERÊNCIAS 


\section{REFERÊNCIA*}

ALTMAN, J.; SUDARSHAN, K. Postnatal development of locomotion in the laboratory rat. Anim. Behav., v. 23, n. 4, p. 896-920, 1975.

ALVARO, J. D.; TATRO, J. B.; QUILLAN, J. M.; FOGLIANO, M.; EISENHARD, M.; LERNER, M. R.; NESTLER, E. J.; DUMAN, R. S. Morphine downregulates melanocortin-4 receptor expression in brain regions that mediate opiate addiction. Mol. Pharmacol., v. 50, p. 583-591, 1996.

AMMON-TREIBER, S.; HÖLLT, V. Morphine-induced changes of gene expression in the brain. Addict. Biol., v. 10, n. 1, p. 81-89, 2005.

AVIDOR-REISS, T.; NEVO, I.; LEVY, R.; PFEUFFER, T.; VOGEL, Z. Chronic opioid treatment induces adenylyl cyclase V superactivation. Involvement of Gbetagamma. J. Biol. Chem., v. 30, n. 35, p. 21309-21315, 1996.

ANDERSEN, M. L.; TUFIK, S. Animal models as tools in ethical biomedical research. São Paulo, SP: CLR Balieiro Editores, 2010. Cap. 11, p. 152.

BABBINI, M.; DAVIS, W. M. Time-dose relationships for locomotion activity effects of morphine after acute or repeated treatment. Br. J. Pharmacol., v. 46, p. 213-224, 1972.

BALS-KUBIK, R.; ABLEITNER, A.; HERZ, A.; SHIPPENBERG, T. S. Neuroanatomical sites mediating the motivational effects of opioids as mapped by the conditioned place preference paradigm in rats. J. Pharmacol. Exp. Ther., v. 264, n. 1, p. 489-495, 1993.

BARTOLETTI, M.; GAIARDI, M.; GUBELLINI, G.; BACCHI, A.; BABBINI, M. Longterm sensitization to the excitatory effects of morphine. A motility study in post-dependent rats. Neuropharmacology, v. 22, p. 1193-1196,1983.

BECKSTEAD, R. M.; DOMESICK, V. B.; NAUTA, W. J. H. Efferent connections of the substantia nigra and ventral tegmental area in the rat. Brain Res., v. 175, p. 191-217, 1979.

BEHBEHANI, M. M. Functional characteristics of the midbrain periaqueductal gray. Prog. Neurobiol., v. 46, n. 6, p. 575-605, 1995.

BODNAR, R. J.; HADJIMARKOU, M. M. Endogenous opiates and behavior: 2001. Peptides, v. 23, p. 2307-2365, 2002.

BEITZ, A. J. The organization of afferent projections to the midbrain periaqueductal gray of the rat. Neuroscience, v. 7, n.1, p. 133-159, 1982.

*De acordo com: ASSOCIAÇÃO BRASILEIRA DE NORMAS TÉCNICAS. NBR 6023: informação e documentação: referências elaboração. Rio de Janeiro, 2002. 
BIERCZYNSKA-KRZYSIK, A.; PRADEEP JOHN, J. P.; SILBERRING, J.; KOTLINSKA, J.; DYLAG, T.; CABATIC, M.; LUBEC, G. Proteomic analysis of rat cerebral cortex, hippocampus and striatum after exposure to morphine. Int. J. Mol. Med., v. 18, n.4, p. 775784, 2006.

BHARGAVA, H. N. Multiple opiate receptors of brain and spinal cord in opiate addiction. Gen. Pharmacol., v. 22, n.5, p. 767-72, 1991.

BODNAR, R. J. Endogenous opiates and behavior: 2008. Peptides, v. 30, n. 12, p. 2432-79, 2009.

BODNAR, R. J. Endogenous opiates and behavior: 2011. Peptides, v. 38, n. 2, p. 463-522, 2009.

BONCI, A.; WILLIAMS, J. T. Increased probability of GABA release during withdrawal from morphine. J. Neurosci., v. 15, n. 2, p. 796-803, 1997.

BRANDÃO, M. L. As bases biológicas do comportamento: introdução a neurociência. Rio de Janeiro, RJ: EPU, 2008. Cap. 5, p. 59-61.

BRIDGES, R. S.; GRIMM, C. T. Reversal of morphine disruption of maternal behavior by concurrent treatment with the opiate antagonist naloxone. Science, v. 218, p. 166-168, 1982.

BRIDGES, R. S.; RONSHEIM, P. M. Immunoreactive beta-endorphin concentrations in brain and plasma during pregnancy in rats: possible modulation by progesterone and estradiol. Neuroendocrinology, v. 45, p. 381-388, 1987.

BRIDGES, R. S.; NUMAN, M.; RONSHEIM, P. M.; MANN, P. E.; LUPINI, C. E. Central prolactin infusions stimulate maternal behavior in steroid-treated, nulliparous female rats. Proceedings of the National Academy of Sciences of the United States of America. v. 87, n. 20, p. 8003-8007, 1990.

BRIDGES, R. S.; ROBERTSON, M. C.; SHIU, R. P.; FRIESEN, H. G.; STUER, A. M.; MANN, P. E. Endocrine communication between conceptus and mother: placental lactogen stimulation of maternal behavior. Neuroendocrinology, v. 64, n. 1, p. 57-64, 1996.

BRIDGES, R. S.; ROBERTSON, M. C.; SHIU, R. P.; STURGIS, J. D.; HENRIQUEZ, B. M. MANN, P. E. Central lactogenic regulation of maternal behavior in rats: Steroid dependence, hormone specificity, and behavioral potencies of rat prolactin and rat placental lactogen I. Endocrinology, v. 138, n. 2, p. 756-763, 1997.

BROWNSTEIN, M. J. A brief history of opiates, opioid peptides, and opioid receptors.

Proc. Natl. Acad. Sci., v. 15, n.12, p. 5391-5393, 1993.

BUTLER, A. A.; KESTERSON, R. A.; KHONG, K. A unique metabolic syndrome causes obesity in the melanocortin-3 receptor-deficient mouse. Endocrinology, v. 141, n. 9, p. 3518$3521,2000$. 
BYRNES, E. M. Chronic morphine exposure during puberty induces long-lasting changes in opioid-related mRNA expression in the mediobasal hypothalamus. Brain Res., v. 1190, p. 186-192, 2008.

CADONI, C.; DI CHIARA, G. Reciprocal changes in dopamine responsiveness in the nucleus accumbens shell and core and in the dorsal caudate-putamen in rats sensitized to morphine. Neuroscience., v. 90, p. 447-455, 1999.

CAMARGO, E. L. R. A. Estudo de neuroteratologia em ratos: efeitos da restrição alimentar e da monocrotalina. 2010. Dissertação (Mestrado) - Programa de PósGraduação em Patologia Experimental e Comparada da Faculdade de Medicina Veterinária e Zootecnia, Universidade de São Paulo, 2010.

CANTERAS, N. S.; SIMERLY, R. B.; SWANSON, L. W. Organization of projections from the ventromedial nucleus of the hypothalamus: a Phaseolus vulgaris-leucoagglutinin study in the rat. J. Comp. Neurol., v. 1, n. 1, p. 41-79. 1994.

CARLOS, C. P.; LEMONICA, I. P.; DE GRAVA KEMPINAS, W.; MARQUES PEREIRA, O. C. Does the male reproductive performance depend on the early lactation milk in rats? Physiol. Behav., v. 59, n. 1, p. 147-152, 1996.

CHEN, A. S.; MARSH. D. J.; TRUMBAUER, M. E. Inactivation of the mouse melanocortin3 receptor results in increased fat mass and reduced lean body mass. Nat. Genet., v. 26, n. 1, p. $97-102,2000$.

CHOI, G. B.; DONG, H. W.; MURPH, A. J.; VALENZUELA, D. M.; YANCOPOULOS, G. D.; SWANSON, L. W. Lhx6 delineates a pathway mediating innate reproductive behaviors from the amygdala to the hypothalamus. Neuron., v. 46, p. 647-660, 2005.

CLARK, M. J.; LEVENSON, S. D.; MEDZIHRADSKY, F. Evidence for coupling of the kappa opioid receptor to brain GTPase. Life Sci., v. 10, n. 19, p. 1721-1727, 1986.

COMOLI, E.; RIBEIRO-BARBOSA, E. R.; CANTERAS, N.S. Predatory hunting and exposureto a live predator induce opposite patterns of Fosimmunoreactivity in the PAG. Behav. Brain. Res., v. 138, p. 17-28, 2003.

CONRAD, L. C. A.; PFAFF, D. W. Autoradiographic tracing of nucleus accumbens efferents in the rat. Brain Res., v. 113, p. 589-596, 1976.

COWLEY, M. A.; SMART, J. L.; RUBINSTEIN, M. Leptin activates anorexigenic POMC neurons through a neural network in the arcuate nucleus. Nature, v. 411, n. 6836, p. 480-484, 2001.

CRAIN, S, M.; SHEN, K. F. Modulation of opioid analgesia, tolerance and dependence by Gs-coupled, GM1 ganglioside-regulated opioid receptor functions. Trends. Pharmacol. Sci., v. 19, n. 9, p. 358-365, 1998. 
CRUZ, A. M.; MAIORKA, P. C.; CANTERAS, N. S.; SUKIKARA, M. H.; FELICIO, L. F. Morphine treatment during pregnancy modulates behavioral selection in lactating rats. Physiol. Behav., v. 101, p. 40-44, 2010.

CURLEY, J. P.; MASHOODH, R.; CHAMPAGNE, F. A. Epigenetics and the origins of paternal effects. Horm. Behav., v. 59, n. 3, p. 306-314, 2011.

DE OLIVEIRA, L. F., CAMBOIM, C., DIEHL, F., CONSIGLIO, A. R., QUILLFELDT, J.A. Glucocorticoid-mediated effects of systemic oxytocin upon memory retrieval. Neurobiol. Learn Mem.; v. 87, p. 67-71, 2007.

DE OLIVEIRA, M. S.; DA SILVA FERNANDES, M. J. SCORZA, F. A.; PERSIKE, D. S.; SCORZA, C. A.; DA PONTE, J. B.; DE ALBUQUERQUE, M.; CAVALHEIRO, E. A.; ARIDA, R.M. Acute and chronic exercise modulates the expression of MOR opioid receptors in the hippocampal formation of rats. Brain Res. Bull., v. 30, n. 5, p. 278-283, 2010.

DE VRIES, L.; ELENKO, E.; HUBLER, L.; JONES, T. L.; FARQUHAR, M. G. GAIP is membrane-anchored by a almitoylation and interacts with the activated (GTP-bound) form of Galpha I subunits. Proc. Natl. Acad. Sci., v. 93, p. 15203-15208, 1996.

EGUCHI, M. Recent advances in selective opioid receptor agonists and antagonists. Med. Res. Rev., v. 24, n. 2, p. 122-182, 2004.

FABER, K. A.; HUGHES, C. L. Anogenital distance at birth as a predictor of volume of the sexually dimorphic nucleus of the preoptic area of the hypothalamus and pituitary responsiveness in castrated adult rats. Biol. Reprod., v. 46, n. 1, p. 101-104, 1992.

FALLON, J. H.; MOORE, R. Y. Catecholamine innervation of the basal forebrain. J. Comp. Neurol., v. 180, p. 545-580, 1978.

FAN, L. W.; TANAKA, S.; TIEN, L. T.; MA, T.; ROCKHOLD, R. W.; HO, I. K. Withdrawal from dependence upon butorphanol uniquely increases kappa(1)-opioid receptorbinding in the rat brain. Brain Res. Bull., v. 58. n. 2, p. 149-160, 2002.

FAN, L. W.; TIEN, L. T.; TANAKA, S.; MA, T.; CHUDAPONGSE, N.; SINCHAISUK, S.; ROCKHOLD, R. W.; HO, I. K. Changes in the brain kappa-opioid receptor levels of rats in withdrawal from physical dependence upon butorphanol. Neuroscience., v. 121, n. 4, p. 1063-1074, 2003.

FANSELOW, M. S. The midbrain periaqueductal gray as a coordinator of action in response to fear and anxiety.In: The midbrain periaqueductal gray matter: functional, anatomical, and neurochemical organization. New York, Plenum., p.151-173, 1991.

FELICIO, L. F.; MANN, P. E.; BRIDGES, R. S. Intracerebroventricular Cholecystokinin Infusions Block Beta-Endorphin-Induced Disruption Of Maternal Behavior. Pharmacol. Biochem. Behav., v. 39, p. 201-204, 1991. 
FERNÁNDEZ-GUASTI, A.; ROLDÁN-RÓLDAN, G.; SALDÍVAR, A. Pharmacological manipulation of anxiety and male rat sexual behavior. Pharmacol. Biochem. Behav., v. 35, p. 263-267, 1990.

FILE, S. E.; GONZALEZ, L. E.; ANDREWS, N. Comparative study of pre- and postsynaptic 5-HT1A receptor modulation of anxiety in two ethological animal tests. J. Neurosci., v. 1, n. 15, p. 4810-4815, 1996.

FILE, S. E.; HYDE, J. R. A test of anxiety that distinguishes between the actions of benzodiazepines and those of other minor tranquilisers and of stimulants. Pharmacol Biochem. Behav., v. 11, n. 1, p. 65-69, 1979.

FINN, A. K.; WHISTLER, J. L. Endocytosis of the mu opioid receptor reduces tolerance and a cellular hallmark of opiate withdrawal. Neuron., v. 6, n. 5, p. 829-839, 2001.

FISHER, L., ARTHURI, M. T., TORRES-CHA`VEZ, K. E., TAMBELI, C. H. Contribution of endogenous opioids to gonadal hormones-induced temporomandibular joint antinociception. Behav. Neurosci., v. 123, p. 1129-1240, 2009.

FRANKOVÁ, S. Behavioural responses of rats to early housing conditions and to proteinenergy malnutrition. Act. Nerv. Super., (Praha). v. 27, n. 2, p. 89-98, 1985.

GARZÓN, J.; RODRÍGUEZ-DÍAZ, M.; LÓPEZ-FANDO, A.; GARCÍA-ESPAÑA, A.; SÁNCHEZ-BLÁZQUEZ, P. Glycosylated phosducin-like protein long regulates opioid receptor function in mouse brain. Neuropharmacology, v. 42, n. 6, p. 813-828,2002.

GEE, C. E.; CHEN, C. L.; ROBERTS, J. L.; THOMPSON, R.; WATSON, S. J. Identification of proopiomelanocortin neurones in rat hypothalamus by in situ cDNA-mRNA hybridization. Nature., v. 306, n. 5941, p. 374-376, 1983.

GILBERT, P. E.; MARTIN W. R. The effets os morphine-like drugs in the nondependent, morphin-dependent and cyclazocine-dependent chronic spinal dog. J. Pharmacol. Exp., v. 198, n. 1, p. 66-82, 1976.

GUPTA, C.; SHAPIRO, B. H.; YAFFE, S. J. Reproductive dysfunction in male rats following prenatal exposure to phenobarbital. Pediatr. Pharmacol., (New York). v. 1, n. 1, p. 55-62, 1980.

GUPTA, C.; SIEGEL, S.; ELLIS, D. The role of EGF in testosterone-induced reproductive tract differentiation. Dev Biol., v. 146, n. 1, p. 106-116,1991.

GUPTA, A.; MULDER, J.; GOMES, I.; ROZENFELD, R.; BUSHLIN, I.; ONG, E.; LIM, M.; MAILLET, E.; JUNEK, M.; CAHILL, C. M.; HARKANY, T.; DEVI, L. A. Increased abundance of opioid receptor heteromers after chronic morphine administration. Sci. Signal., v. $20 ; 3$, n.131, p. $54,2010$.

GUTSTEIN, H. B.; AKIL, H. Analgésicos opióides. In: HARDMAN, J. G.; LIMBIRD, L. E. (Ed.). Goodman \& Gilman: as bases farmacológicas da terapêutica. 10. ed. Rio de Janeiro: Mc Graw-Hill; 2005. p. 427-464. 
HABER, S. N.; GROENEWEGEN, H. J.; GROVE, E. A. \& NAUTA, W. J. H. Efferent connections of the ventral pallidum: evidence of a dual striato-pallidorugal pathway. $\mathbf{J}$. Comp. Neurol., v. 235, p. 322-335, 1985.

HABERSTOCK-DEBIC, H.; WEIN， M.; BARROT， M.; COLAGO， E. E.; RAHMAN, Z.; NEVE, R. L.; PICKEL, V. M.; NESTLER, E. J.; VON ZASTROW, M;, SVINGOS, A. L. Morphine acutely regulates opioid receptor trafficking selectively in dendrites of nucleus accumbens neurons. J. Neurosci., v. 15;32, n. 10, p. 4324-32,2003.

HAGAN, M. M.; RUSHING, P. A.; BENOIT, S. C.; WOODS, R. J. Opioid receptor involvement in the effect of AgRP- (83-132) on food intake and food selection Am J Physiol Regulatory Integrative Comp. Physiol., v. 280, p. 814-821, 2001.

HAGHPARAST, A.; ESMAEILI, M.; TASLIMI, Z.; KERMANI, M.; YAZDI-RAVANDI, S. ALIZADEH, A. Intrahippocampal administration of D2 but not D1 dopamine receptor antagonista suppresses the expression of conditioned place preference induced by morphine in the ventral tegmental área. Neuroscience Letters., v. 541, p. 138-143, 2013.

HAMMER, R. P. JR; BRIDGES, R.S. Preoptic area opioids and opiate receptors increase during pregnancy and decrease during lactation. Brain Res., v. 420, p. 48-56, 1987.

HAMMER, R. P., JR. MATEO, A. R., BRIDGES, R. S. Hormonal regulation of medial preoptic mu-opiate receptor density before and after parturition. Neuroendocrinology., v. 56, p. 38-45, 1992.

HAO, Y.; HUANG, W.; NIELSEN, D. A.; KOSTEN, T. A. Litter gender composition and sex affect maternal behavior and DNA methylation levels of the Oprm1 gene in rat offspring. Front. Psychiatry., p. 2-21, 2011.

HARBISON, R. D. Parathion-induced toxicity and Phenobarbital-induced protection against parathion during prenatal development. Toxicol. Appl. Pharmacol., v. 32, p. 482-493, 1975.

HAYS, S. L., VALIEVA, O. A., MCPHERSON, R. J., JUUL, S. E., GLEASON, C. A. Adult responses to an ischemic stroke in a rat model of neonatal stress and morphine treatment. International Journal of Developmental Neuroscience, 2012.

HE, S.Q.; ZHANG, Z. N.; GUAN, J. S.; LIU, H. R.; ZHAO, B.; WANG, H. B.; LI, Q.;YANG, H.; LUO, J.; LI, Z. Y.; WANG, Q.; LU, Y.J.; BAO, L.; ZHANG, X. Facilitation of $\mu$-opioid receptor activity by preventing $\delta$-opioid receptor-mediated codegradation. Neuron., v. 13, n. 1, p. 120-31, 2011.

HEMBY, S. E. Morphine-induced alterations in gene expression of calbindin immunopositive neurons in nucleus accumbens shell and core. Neuroscience., v. 126, n. 3, p. 689-703, 2004.

HENNESSEY, A. C.; CAMAK, L.; GORDON, F.; EDWARDS, D. A. Connectionsbetween the pontine central gray and the ventromedial hypothalamus are essential for lordosis in female rats. Behav. Neurosci., v. 104, p. 477-488, 1990. 
HERNÁNDEZ-TRISTÁN, R.; AREVALO, C.; CANALS, S. Effect of prenatal uterine position on male and female rats sexual behavior. Physiol. Behav., v. 67, n. 3, p. 401-408, 1999.

HOLSTEGE, G. An anatomical study on the final common pathway for vocalization in the cat.J. Comp. Neurol., v. 284, p. 242-252, 1989.

HOUILLON, C. Generalidades. In: . Embriologia., São Paulo, Edgar Blücher, 1972. p. 1-16.

HULL, E. M.; LORRAIN, D. S.; DU, J.; MATUSZEWICH, L.; LUMLEY, L. A.; PUTNAM, S. K.; MOSES, J. Hormone-neurotransmitter interactions in the control of sexual behavior. Behav. Brain Res., v. 105, p. 105-116, 1999.

HUSZAR, D.; LYNCH, C. A.; FAIRCHILD-HUNTRESS, V. Targeted disruption of the melanocortin-4 receptor results in obesity in mice. Cell, v. 88, n. 1, p. 131-141, 1997.

JACOBOWITZ, D. M.; O'DONOHUE, T. L. Alpha- Melanocyte stimulating hormone: immunohistochemical identification and mapping in neurons of rat brain. Proc. Natl. Acad. Sci., v. 75, n. 12, p. 6300-6304, 1978.

JOHNSON, N. L.; CARINI, L.; SCHENK, M. E.; STEWART, M.; BYRNES, E.M. Adolescent opiate exposure in the female rat induces subtle alterations in maternal care and transgenerational effects on play behavior. Front. Psychiatry, 2011.

JORDAN, B. A.; DEVI, L. A. G-protein-coupled receptor heterodimerization modulates receptor function. Nature., v. 17, n. 67371, p. 697-700,1999.

KACSÓH, B.; NAGY, G.; VERESS, Z.; TOTH, B. E.; KANYICSKA, B.; CSERNUS, V.; KOVES, K. Data suggesting that milk of early lactation period might be involved in sexual differentiation of rat brain. Endocrinol. Exp., v. 20, p. 155-166, 1986.

KAEWSUK, S.; HUTAMEKALIN， P.; KETTERMAN， A. J.; KHOTCHABHAKDI, N.; GOVITRAPONG, P.; CASALOTTI, S. O. Morphine induces short-lived changes in Gprotein gene expression in rat prefrontal cortex. Eur. J. Pharmacol., v. 5, n. 2, p. 11-16, 2001.

KELZ, M. B.; CHEN, J.; CARLEZON, W. A. JR.; WHISLER, K.; GILDEN, L.; BECKMANN, A. M.; STEFFEN, C.; ZHANG, Y. J.; MAROTTI, L.; SELF, D. W.; TKATCH, T.; BARANAUSKAS, G.; SURMEIER, D. J.; NEVE, R. L.; DUMAN, R. S.; PICCIOTTO, M. R.; NESTLER, E. J. Expression of the transcription factor deltaFosB in the brain controls sensitivity to cocaine. Nature., v. 16; 401, n. 6750, p. 272-276, 1999.

KHERA, K. S. Maternal toxicity--a possible factor in fetal malformations in mice. Teratology, v. 29, n. 3, p. 411-416, 1984.

KIEFFER, B. L.; EVANS, C. J. Opioid receptors: from binding sites to visible molecules in vivo. Neuropharmacology, v. 56, n. 1, p. 205-212, 2009. 
KINSLEY, C. H.; BRIDGES, R. S. Parity-associated reductions in behavioral sensitivity to opiates.Biol. Reprod., v. 39, p. $270-278,1988$.

KINSLEY, C. H.; BRIDGES, R. S. Morphine treatment and reproductive condition alter olfactory preferences for pup and adult male odors in female rats. Dev. Psychobiol., v. 23, p. 331-347, 1990.

KINSLEY， C. H.; MADONIA， L.; GIFFORD， G.W.; TURESK,I K.; GRIFFIN， G. R.; LOWRY， C.; WILLIAMS， J.; COLLINS， J.; MCLEARIE， H.; LAMBERT， K.G. Motherhood improves learning and memory. Nature., v. 402, n. 6758, p. 137-138, 1999.

KINSLEY, C. H.; AMORY-MEYER,E. Why the Maternal Brain? J. Neuroendocrinol., v. 23, n. 11, p. 974-983, 2011.

KLEIN, M. O. Papel dos receptores opióides $\boldsymbol{\mu}$ e $\kappa$ da substância cinzenta periaquedutal (PAG) na seleção comportamental durante a lactação. 2012. 79 f. Dissertação (Mestrado em Farmacologia) - Instituto de Ciências Biomédicas, Universidade de São Paulo, São Paulo, 2012.

KORNETSKY, C. Brain-stimulation reward, morphine-induced oral stereotypy, and sensitization: implications for abuse. Neurosci. Biobehav. Rev., v. 27, p. 777-786, 2004.

KUHN, L.; KLINE, J.; NG, S.; LEVIN, B.; SUSSER, M. Cocaine use during pregnancy and intrauterine growth retardation: new insights based on maternal hair tests. Am. J. Epidemiol., v. 15, n. 2 , p. $112-119,2000$.

KURIBARA, H. Effects of interdose interval on ambulatory sensitization to methamphetamine, cocaine and morphine in mice. Eur. J. Pharmacol., v. 28, p. 1-5, 1996.

LEMONICA, I. P.; DAMASCENO, D. C.; DI-STASI, L. C. Study of the embryotoxic effects of an extract of rosemary (Rosmarinus officinalis L.). Braz. J. Med. Biol. Res., v. 29, n. 2, p. 223-227, 1996.

LEON, M.; ADELS, L.; COOPERSMITH, R. Thermal limitation of mother-young contact in Norway rats. Dev. Psychol., v. 18, p. 85-105, 1985.

LEONARD, B. E. Behavioural teratology: post-natal consequences of drug exposure in utero. Arch. Toxicol. Suppl., v. 5, p. 48-58, 1982.

LI, H.; ZHOU, Y.; KANG, L.; MA, L. Single and repeated morphine administrations differently regulate expression of N-ethylmaleimide-sensitive factor gene in the rat brain. Neuroreport., v. 23, n. 1, p. 71-74, 2006.

LONSTEIN, J. S.; STERN, J. M. Role od the midbrain periaqueductal gray in maternal nurturance and aggression: c-fos and electrolytic lesion studies in lactating rats. J. Neurosci., v. 17, p. 3364-3378, 1997.

LORD, J. A. H.; WATERFIELD, A. A.; HUGHES, J.; KOSTERLITZ, H. W. Endogenous opioid peptides: multiple agonists and receptors. Nature, v. 267, p.495-499, 1977. 
LOVICK, T. A.; DEVALL, A. J. Progesterone withdrawal-evoked plasticity of neural function in the female periaqueductal grey matter. Neural Plast., 2009.

LU, D.; WILLARD, D.; PATEL, I. R. Agouti protein is an antagonist of the melanocytestimulatinghormone receptor. Nature, v. 371, n. 6500, p. 799-802, 1994.

MANN, P. E.; KINSLEY, C. H.; BRIDGES, R. S. Opioid receptor subtype involvement in maternal behavior in lactating rats. Neuroendocrinology, v. 53, p. 487-492, 1991.

MANN, P. E., BRIDGES, R. S. Neural and endocrine sensitivities to opioids decline as a function of multiparity in the rat. Brain Res., v. 580, p. 241-248, 1992.

MANSOUR, A.; FOX, C. A.; BURKE, S.; MENG, F.; THOMPSON, R. C.; AKIL, H.; WATSON, S. J. Mu, delta, and kappa opioid receptor mRNA expression in the rat CNS: an in situ hybridization study. J. Comp. Neurol., v. 350, p. 412-438, 1994.

MANSOUR, A.; FOX, C. A.; AKIL, H.; WATSON, S. J. Opioid-receptor mRNA expression in the rat CNS: anatomical and functional implications. Neuroscience., v. 18, p. 22-29, 1995.

MARGOLIS, E. B.; HJELMSTAD, G. O.; BONCI, A.; FIELDS, H. L.Both kappa and mu opioid agonists inhibit glutamatergic input to ventral tegmental area neurons. $\mathbf{J}$ Neurophysiol., v. 93, n. 6, p. 3086-3093, 2005.

MARTINI, L.; WHISTLER, J. L.The role of mu opioid receptor desensitization and endocytosis in morphine tolerance and dependence. Curr. Opin. Neurobiol., v. 17, n. 5, p. 556-564, 2007.

MATTSON, B. J.; WILLIAMS, S.; ROSENBLATT, J. S.; MORRELL, J. I. - Compararion of two positive reinforcing stimuli: pups and cocaine throughout the postpartum period. Behavioral Neurosci., v. 115, p.683-694, 2001.

MCCLUNG, C. A.; NESTLER, E. J.; ZACHARIOU, V. Regulation of gene expression by chronic morphine and morphine withdrawal in the locus ceruleus and ventral tegmental area. J. Neurosci., v. 22, n. 25, p. 6005-6015. 2005.

MCCOY, S.J.; SHIRLEY, B. A. Effects of prenatal administration of testosterone and cortisone on the reproductive system of the female rat. Life Sci., v. 50, n. 9, p. 621-628, 1992.

MIRANDA-PAIVA, C. M. Interação da morfina com bloqueadores de sub-tipos de receptores de colecistocinina no comportamento maternal de ratas. Dissertação (Mestrado) - Instituto de Psicologia, Universidade de São Paulo, São Paulo, 1999.

MIRANDA-PAIVA, C. M., FELICIO, L. F. Differential role of cholecystokinin receptor subtypes in opioid modulation of ongoing maternal behavior. Pharmacol. Biochem. Behav., v. 64, p. 165-169, 1999. 
MIRANDA-PAIVA, C. M.; NASELLO, A. G.; YIM, A. J.; FELICIO, L. F. Morphine pretreatment increases opioid inhibitory effects on maternal behavior. Brain Res. Bull., v. 55, p. 501-505, 2001.

MIRANDA-PAIVA, C. M.; NASELlO, A. G.; YIM, A. J.; FELICIO, L. F. Puerperal blockade of cholecystokinin $\left(\mathrm{CCK}_{1}\right)$ receptors disrupts maternal behavior in lactating rats. $\mathbf{J}$. Mol. Neurosci., v. 18, p. 97-104, 2002.

MIRANDA-PAIVA, C. M.; RIBEIRO-BARBOSA E. R.; CANTERAS, N. S.; FELICIO, L. F. A Role for the periaqueductal gray in opioidergic inhibition of maternal behavior. Eur. $\mathbf{J}$. Neurosci., v.18, p. 667-674, 2003a.

MIRANDA-PAIVA, C. M. Relação colecistocinina-opióides no controle do comportamento maternal. Tese (Doutorado em Neurociências e Comportamento) - Instituto de Psicologia. Universidade de São Paulo, São Paulo 2003b.

MIRANDA-PAIVA, C.; CANTERAS, N. S.; SUKIKARA, M. H. ; NASELLO, A. G. ; MACKOWIAK, I. I. ; FELICIO, L. F. Periaqueductal gray cholecystokinin infusions block morphine-induced disruption of maternal behavior. Peptides, v. 28, p. 657-662, 2007.

MOLlEREAU, C.; PARMENTIER, M.; MAILlEUX, P.; BUTOUR, J.L.; MOISNAD, C.; CHALON, P.; CAPUT, D.; VASSART, G.; MEUNIER, J. C. ORL1, a novel member of the opioid receptor family. Cloning, functional expression and localization. FEBS Lett., v. 341, p. 33-38, 1994.

MOLTZ, H.; LUBIN, M.; LEON, M.; NUMAN, M. Hormonal induction of maternal behavior in the ovariectomized nulliparous rat. Physiol. Behav., v. 5, p. 1373-1377, 1970.

MORÓN, J. A.; DEVI, L. A. Use of proteomics for the identification of novel drug targets in brain diseases. J. Neurochem., v. 102, n. 2, p. 306-315, 2007.

MOURA, L. M.; CANTERAS, N. S.; SUKIKARA, M. H.; FELICIO, L. F. Morphine infusions into the rostrolateral periaqueductal gray affect maternal behaviors. Braz. J. Med. Biol. Res., v. 43, n. 9, p. 899-905, 2010.

MOTA-ORTIZ, S. R.; SUKIKARA, M. H.; FELICIO, L. F.; CANTERAS, N. S. Afferent connections to the rostrolateral part of the periaqueductal gray: a critical region influencing the motivation drive to hunt and forage. Neural. Plast., 2009.

MOUNT, D. L.; FEENEY, P.; FABRICATORE, A. N.; CODAY, M.; BAHNSON, J.; BYINGTON, R.; PHELAN, S.; WILMOTH, S.; KNOWLER, W. C.; HRAMIAK, I.; OSEI, K.; SWEENEY, M. E.; ESPELAND, M. A.; LOOK. Constructing common cohorts from trials with overlapping eligibility criteria: implications for comparing effect sizes between trials. AHEAD and ACCORD Research Groups. Clin. Trials., v. 6, n. 5, p. 416-429, 2009.

MOUNTJOY, K .G.; WILD, J. M. Melanocortin-4 receptor mRNA expression in the developing autonomic and central nervous systems. Brain Res. Dev. Brain Res., v. 107, n. 2, p. 309-314, 1998. 
NEASTA, J.; UTTENWEILER-JOSEPH, S.; CHAOUI, K.; MONSARRAT, B.; MEUNIER, J. C.; MOULÉDOUS, L. Effect of long-term exposure of SH-SY5Y cells to morphine: a whole cell proteomic analysis. Proteome. Sci., v. 21, p. 4-23, 2006.

NUMAN, M. Maternal behavior. In: KNOBIL, E.; NEILL, J. D. (Ed.). The physiology of reproduction. 2nd ed. New York: Raven Press, 1994.

NUMAN, M., INSEL, T. R. The neurobiology of parental behavior. New York: SpringerVerlag, 2003.

NUMAN, M.; FLEMING, A. S.; LEVY, F. Maternal Behavior. In: NEILL, J. D. (Ed.), Knobil and Neill's physiology of reproduction. New York: Elsevier, 2006. p. 1921-1993.

NUMAN, M. Hypothalamic neural circuits regulating maternal responsiveness toward infants.Behavioral and Cognitive Neuroscience Reviews, v. 5, n. 4, p. 163-190, 2006.

NUMAN, M.; STOLZENBERG, D. S. Medial preoptic area interactions with dopamine neural systems in the control of the onset and maintenance of maternal behavior in rats.Frontiers in Neuroendocrinology, v. 30, n. 1, p. 46-64, 2009.

NESTLER, H. P. Sequence-selective nonmacrocyclic two-armed receptors for peptides. Mol. Divers.,v. 2, n. 1-2, p. 35-40, 1996.

NESTLER, E. J.; AGHAJANIAN, G.K. Molecular and cellular basis of addiction. Science, v. $3 ; 278$, n. 5335, p. 58-63, 1997.

NESTLER, E. J. Molecular neurobiology of addiction. Am. J. Addict., v. 10, n. 3, p. 201$217,2001$.

OLLMANN, M. M.; WILSON, B. D.; YANG, Y. K. Antagonism of central melanocortin receptors in vitro and in vivo by agouti-related protein. Science., v. 278, n. 5335, p. 135-138, 1997.

PAN, H. L.; WU, Z. Z.; ZHOU, H. Y.; CHEN, S. R.; ZHANG, H. M.; LI, D .P. Modulation of pain transmission by G-protein-coupled receptors. Pharmacol. Ther., v. 117, n. 1, p. 141$161,2008$.

PALERMO-NETO, J. Supersensitivity, drug withdrawal, and open field behavior. Psychopharmacol. Bull., v. 18, n. 4, p. 11-12, 1982.

PASTERNAK, G. W.; WOOD, P .J. Multiple mu opiate receptors. Life Sci., v. 26, n. 21, p. 1889-1898, 1986.

PASTERNAK, G.W. Multiple morphine and enkephalin receptors and the relief of pain. JAMA, v. 4, n. 9, p. 1362-1367, 1988.

PASTERNAK, G. W.; STANDIFER, K. M. Mapping of opioid receptors using antisense oligodeoxynucleotides: correlating their molecular biology and pharmacology. Trends. Pharmacol. Sci., v. 16, n. 10, p. 344-350, 1995. 
PASTERNAK, G. W. Molecular insights into mu opioid pharmacology: from the clinic to the bench. Clin. J. Pain., 2010.

PAXINOS, G.; WATSON, C. The rat brain in stereotaxic coordinates. New York: Academic Press, 1986.

PFAFF, D. W.; SAKUMA, Y. Deficit in the lordosis reflex of female rats caused by lesions in the ventromedial nucleus of the hypothalamus. J. Physiol., v. 288. p. 203-210. 1979a.

PFAFF, D. W.; SAKUMA, Y. Facilitation of female reproductive behavior from mesensephalic central gray in the rat. J. Physiol., v. 237, n. 5, p. 278-284. 1979b.

PORTOGHESE, P. S.; SULTANA, M.; NELSON, W. L.; KLEIN, P.; TAKEMORI, A. E. Delta opioid antagonist activity and binding studies of regioisomeric isothiocyanate derivatives of naltrindole: evidence for delta receptor subtypes. J. Med. Chem., v. 35, p. 4086-4091, 1992.

PORTOGHESE, P. S.; MOE, S. T.; TAKEMORI, A. E. A selective delta 1 opioid receptor agonist derived from oxymorphone. Evidence for separate recognition sites for delta 1 opioid receptor agonists and antagonists. J. Med. Chem., v. 36, p. 2572-2574, 1993.

PROKAI, L.; ZHARIKOVA, A. D.; STEVENS, S. M. JR. Effect of chronic morphine exposure on the synaptic plasma-membrane subproteome of rats: a quantitative protein profiling study based on isotope-coded affinity tags and liquid chromatography/mass spectrometry. J. Mass. Spectrom., v. 40, n. 2, p. 169-175, 2005.

PRZEWLOCKI, R. Opioid abuse and brain gene expression. Eur. J. Pharmacol., v. 1, n. 1-3, p. 331-349, 2004.

QIU, J.; BOSCH, M. A.; RØNNEKLEIV, O. K.; KLOOSTERBOER, H. J.; KELLY, M. J.

Tibolone rapidly attenuates the GABAB response in hypothalamic neurones. $\mathbf{J}$. Neuroendocrinol., v. 20, n. 12, p. 1310-1318, 2008.

RANG, H. P.; DALE, M. M.; RITTER, J.; FLOWER, R. J. Rang \& Dale: Farmacologia. 6. ed. Rio de Janeiro: Elsevier, 2007. Seção 4, p. 588-609.

RONCA, A. E.; LAMKIN, C. A.; ALBERTS, J. R. Maternal Contributions to Sensory Experience in the Fetal and Newborn Rat (Rattus norvegicus). J. Comp. Psychol., v. 107, n. 1, p. 61-74, 1993.

ROSENBLATT, J. S. Nonhormonal basis of maternal behavior in the rat.Science, v. 156, p. 1512-1514, 1967.

RUBIN, B. S.; BRIDGES, R. S. Disruption of ongoing maternal responsiveness in rats by central administration of morphine sulfate. Brain Res., v. 307, p. 91-97, 1984.

SAGRILLO, C. A., VOOGT, J. L. Endogenous opioids mediate the nocturnal prolactin surge in the pregnant rat. Endocrinology, v. 129, p. 925-930, 1991. 
SALVATORI, F.; TALASSIA, C. B.; SALZGEBERB, S. A.; SPINOSA, M. M. Embryotoxic and long-term effects of cadmium exposure during embryogenesis in rats. Neurotoxicology and Teratology., v. 26, p. 673-680, 2004.

SANYAL, M. K. Secretion of progesterone during gestation in the rat. J. Endocrinol., v. 79, p. 179-190, 1978.

SEGOVIA, S.; GUILLAMÓN, A.; del CERO, M. C. R.; ORTEGA, E.; PÉREZ-LASO, C.; RODRIGUES-ZAFRA, M; BEYER, C. The development of brain sex differences: a multisignaling process. Behav. Brain Res., v. 105, p. 69-80, 1999.

SHAIKH, A. A. Estrone and estradiol levels in the ovarian venous blood from rats during the estrous cycle and pregnancy. Biol. Reprod., v. 5, p. 297-307, 1971.

SHENOY, S. K.; LEFKOWITZ, R. J. Receptor regulation: beta-arrestin moves up a notch. Nat. Cell. Biol., v. 7, n. 12, p. 1159-1161, 2005.

SIMON, H.; LE MOAL, M.; CALAS, A. Efferents and afferents of the ventral tegmental-A10 region studied after local injection of $\left[{ }^{3} \mathrm{H}\right]$-leucine and horseradish peroxidase. Brain Res., v. 178, p. 17-40, 1979.

SISK, C. L.; RICHARDSON, P. E.; CHAPPELL, J. E.; LEVINE, J. E. In vivo gonadotropinreleasing hormone secretion in female rats during peripubertal development and on proestrus, Endocrinology., v. 142, p. 2929-2936, 2001.

SMART, J. L.; DOBBING, J. Vulnerability of developing brain. VI. Relative effects of foetal and early postnatal undernutrition on reflex ontogeny and development of behaviour in the rat. Brain Res., v. 29, n. 2, p. 303-314, 1971.

SMITH, E. R.; DAMASSA, D. A.; DAVIDSON, J. M. Feedback regulation and male puberty: testosterone-luteinizing hormone relationships in the developing male rat, Endocrinology, v. 101, p. 173-180, 1977.

SNYDER, S. H.; PASTERNAK, G. W. Historical review: Opioid receptors. Trends Pharmacol. Sci., v. 24, n. 4, p. 198-205, 2003.

SOBOR, M.; TIMÁR, J.; RIBA, P.; FRIEDMANN, T.; KIRALY, K.P., GYARMATI, S.; AL-KHRASANI, M.; FÜRST, S. Effects of opioid agonist and antagonist in dams exposed to morphine during the perinatal period. Brain Research Bulletin., v. 84, p. 53-60, 2011.

SPANAGEL, R. Modulation of drug-induced sensitization processes by endogenous opioid systems. Behav. Brain Res., v. 70, n. 1, p. 37-49, 1995.

STERN, J. M.; LONSTEIN, J. S. Neural mediation of nursing and related maternal behaviors. Prog. Brain Res., v. 133, p. 263-278, 2001.

SUKIKARA, M. H.; MOTA-ORTIZ, S. R.; BALDO, M. V.; FELICIO, L. F.; CANTERAS, N. S. A role for the periaqueductal gray in switching adaptive behavioral responses. $\mathbf{J}$. 
Neurosci., v. 26, p. 2583-2589, 2006.

SUKIKARA, M. H.; PLATERO, M. D.; CANTERAS, N. S.; FELICIO, L. F. Opiate regulation of behavioral selection during lactation. Pharmacol. Biochem. Beh., v. 90, p. 1$11,2007$.

SUKIKARA, M. H., MOTA-ORTIZ, S.R., BALDOD, M.V., FELICIO, L.F., CANTERAS, N.S. The periaqueductal gray and its potential role in maternal behavior inhibition in response to predatory threats. Behavioural Brain Research, v. 209, p. 226-233, 2010.

SUKIKARA, M. H., CRUZ, A. M., FELIPPE, E. C. G., ANSELMO-FRANCI, J. A., CANTERAS, N. S., OLIVEIRA, C. A., FELICIO,L. F. Morphine-Induced Changes in Opioid Sensitivity in Postpartum Females: A Unique Progesterone Response. Journal of Neuroendocrinology, v. 23, p. 1134-1138, 2011.

SWANSON, L.W.; MOGENSON, G. J.; GERFEN, C. R.; ROBINSON, P. Evidence for a projection from the lateral preoptic area and substantia innominata to the mesencephalic locomotor region in the rat. Brain Res., v. 295, p. 161-178, 1984.

SWANSON, L. W. The hypothalamus. In: BJORKLUND, A.; HOKFELT, T.; SWANSON, L. W. (Ed.). Handbook of chemical neuroanatomy. Amsterdam: Elsevier, 1987. v. 5, p. 1124.

TAO, Y. X. The Melanocortin-4 receptor: physiology, pharmacology, and pathophysiology. Endocr. Rev., 2010.

TEODOROV, E.; MODENA, C. C.; SUKIKARA, M. H.; FELICIO, L. F. Preliminary study of the effects of morphine treatment on opioid receptor gene expression in brain structures of the female rat. Neuroscience., v. 141, p. 1225-1231, 2006

TEODOROV, E.; HABR, S. F.; BERNARDI, M. M.; FERRARI, M .F. R.; FIORI-CHADI, D. R.; FELICIO, L.F. Reproductive experience modulation on opioid gene expression in periaqueductal grey of nulliparous, primiparous and multiparous female rats. 2008a.

TEODOROV, E.; TOMITA, A. T.; BANON, G. P.R; GIL, I. G.; BERNARDI, M. M., FELÍCIO,L. F. Behavioral effects of acute stimulation of $\kappa$-opioid receptors during lactation. Pharmacology, Biochemistry and Behavior., v. 90, p. 534-539, $2008 \mathrm{~b}$.

TEODOROV, E., BERNARDI, M. M., FERRARI, M. F. R., FIOR-CHADI, D. R., FELICIO, L. F. Plasticity of Opioid Receptors in the Female Periaqueductal Gray: Multiparity-Induced Increase in the Activity of Genes Encoding for $\mathrm{Mu}$ and Kappa Receptors and a Post Translational Decrease in Delta Receptor Expression. J. Mol. Neurosci., v. 43, p. 175-181, 2011.

TERWILlIGER, R. Z.; BEITNER-JOHNSON， D.; SEVARINO， K. A.; CRAIN, S. M.; NESTLER, E. J. A general role for adaptations in G-proteins and the cyclic AMP system in mediating the chronic actions of morphine and cocaine on neuronal function. Brain Res., v. 10, n. 1-2, p. 100-10, 1991. 
THORBURN, G. D.; CHALLIS, J. R. Endocrine control of parturition. Physiol. Rev., v. 59, p. 863-918, 1979.

TIRUMALAI, P. S.; HOWELLS, R. D. Regulation of calbindin-D28K gene expression in response to acute and chronic morphine administration. Brain Res. Mol. Brain Res., v. 23, n. 1-2, p. 144-150, 1994.

VAN GAALEN, M. M.; STECKLER, T. Behavioural analysis of four mouse strains in an anxiety test battery. Behav. Brain Res., v. 115, n. 1, p. 95-106, 2000.

VAN RIJN, R.M.; BRISSETT, D. I.; WHISTLER, J. L. Dual efficacy of delta opioid receptor-selective ligands for ethanol drinking and anxiety. J. Pharmacol. Exp. Ther., v. 335 , n. 1, p. 133-139, 2010.

VANDERSCHUREN, L. J.; DE VRIES, T. J.; WARDEH, G.; HOGENBOOM, F.; SCHOFFELMEER, A. N. A single exposure to morphine induces long-lasting behavioural and neurochemical sensitization in rats. Eur. J. Neurosci., v. 14, p. 1533-1538, 2001.

VARMA, S. K.; BLOCH, E. Effects of prenatal administration of mestranol and two progestins on testosterone synthesis and reproductive tract development in male rats. Acta Endocrinol., v. 116, n. 2, p. 193-199, 1987.

VON ZASTROW, M. Regulation of opioid receptors by endocytic membrane traffic: mechanisms and translational implications. Drug Alcohol Depend. v. 1, n. 3, p. 166-171, 2010.

ZAGON, I. S., MCLAUGHLIN, P.J. Naloxone Modulates Body and Organ Growth of Rats: Dependency on the Duration of Opioid Receptor Blockade and Stereospecificity. Biochemistry \& Behavior., v. 33, p. 325-328, 1989.

ZAIAS, J.; OKIMOTO, L.; TRIVEDI, A.; MANN, P. E.; BRIDGES, R. S. Inhibitory effects of naltrexone on the induction of parental behavior in juvenile rats. Pharmacol. Biochem. Behav., v. 53, p. 987-993, 1996.

ZELEK-MOLIK, A.; TARACHA， E.; NAWRAT, D.; BIELAWSKI， A.; LEHNER, M.; PŁAŹNIK, A.; NALEPA, I. Effects of morphine and methadone treatment on mRNA expression of $\mathrm{G} \alpha(\mathrm{i})$ subunits in rat brains. Pharmacol. Rep., v. 62, n. 6, p. 1197-203, 2010.

ZIMBERKNOPF, E.; XAVIER, G. F.; KINSLEY, C. H.; FELICIO, L .F. Prior parity positively regulates learning and memory in young and middle-aged rats. Comp. Med., v. 61, n. 4, p. 366-3 77, 2011.

WALDHOER, M.; BARTLETT, S. E.; WHISTLER, J.L. Opioid receptors. Annu. Rev. Biochem., v. 73, p. 953-990, 2004.

WANG, Z; BILSKY， E.J.; WANG, D.; PORRECA， F.; SADÉE， W. 3-Isobutyl-1methylxanthine inhibits basal mu-opioid receptor phosphorylation and reverses acute morphine tolerance and dependence in mice. Eur. J. Pharmacol., v. 23, n. 1, p. 1-9, 1999. 
WIESNER, B. P.; SHEARD, N. M. Maternal behavior in the rat. Edinburgh. Oliver and Boyd, 1993.

WISE, R. A.; BOZARTH, M.A. A psychomotor stimulant theory of addiction. Psychol. Rev., v. 94, n. 4, p. 469-492, 1987.

WISE, A.; SHEEHAN, M.; REES, S.; LEE, M.; MILLIGAN, G. Comparative analysis of the efficacy of $\mathrm{A} 1$ adenosine receptor activation of $\mathrm{Gi} / \mathrm{o}$ alpha $\mathrm{G}$ proteins following coexpression of receptor and $\mathrm{G}$ protein and expression of $\mathrm{A} 1$ adenosine receptor-Gi/o alpha fusion proteins. Biochemistry., v. 23, n. 8, p. 2272-2278, 1999.

WHISTLER, J. L.; CHUANG, H. H.; CHU, P.; JAN, L.Y.; ZASTROW, M. Functional dissociation of mu opioid receptor signaling and endocytosis: implications for the biology of tolerance and addiction. Neuron, v. 23, p. 737-746, 1999.

YOUNG, W. C.; ALHEID, G. F.; HEIMER, L. The ventral pallidal projection to the mediodorsal thalamus: a study with fluorescent retrograde tracers and immunohistofluorescence. J. Neurosci., v. 4, p. 1629-1638, 1984.

YU, G.; YAN, H.; GONG, .Z. H. Effects of acute and repeated morphine treatment on $\kappa-$ opioid receptor protein levels in mesocorticolimbic system. J. Recept. Signal Transduct. Res., v. 12, 2012. 


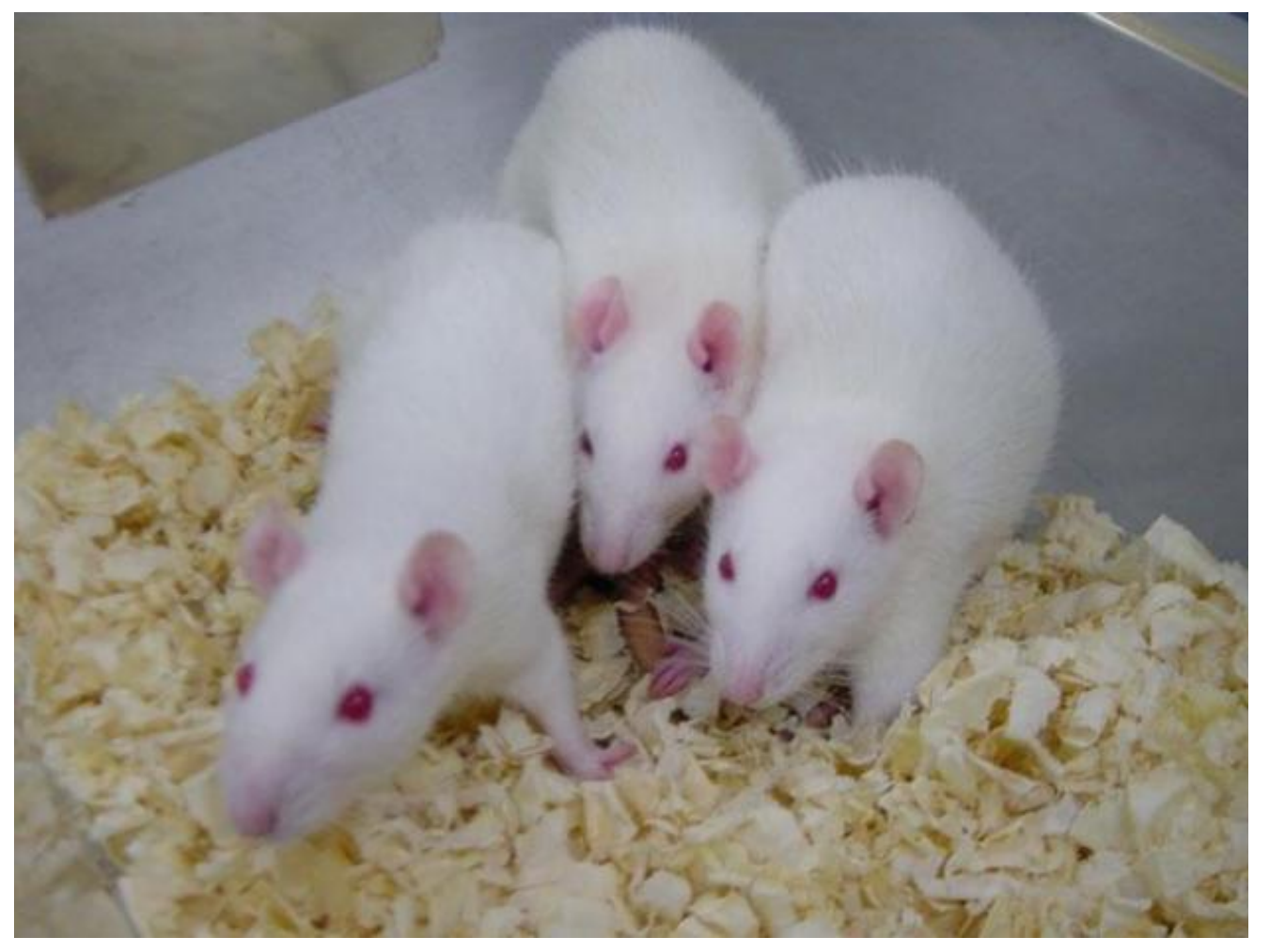

APÊNDICE - Artigo submetido 
Early prenatal exposure to morphine did not alter the maternal behavior but increased male offspring motor activity after a challenged dose of morphine.

${ }^{a}$ Renata Ruggier de Mattos; ${ }^{b}$ Jullie Rosana de Almeida Hernandes; ${ }^{c}$ Luciano Freitas Felicio, Maria Martha Bernardi ${ }^{\mathrm{d}}$ and ${ }^{\mathrm{d}}$ Elizabeth Teodorov.

${ }^{\mathrm{a}}$ Instituto de Ciências Biomédicas, USP; ${ }^{\mathrm{b}}$ Instituto de Ciências da Saúde, UNIP; ${ }^{\mathrm{c}}$ Faculdade de Medicina Veterinária e Zootecnia, USP; 'Centro de Matemática, Computação e Cognição, UFABC, Brasil.

Running head: Prenatal or prenatal morphine and motor behavior.

Conflict of Interest Statement: All authors declare that there are no conflicts of interest.

\section{* Corresponding author:}

Dr. Elizabeth Teodorov

Av dos Estados, 5001, Santo André, São Paulo, Brasil

CEP: 09210-970

Phone: + $55114996-8304$ 


\begin{abstract}
:
Aims. Previous studies have shown that morphine treatment during the last third of pregnancy has an inhibitory effect on the maintenance of maternal behavior that could affect offspring when evaluated in adulthood. The aim of the present study was to investigate the effects of a maternal challenge dose of morphine or saline [lactation day 5] on maternal behavior of dams prenatally exposed in early pregnancy (2-7 days of gestation- GD) to morphine or saline. The effects of these treatments were observed in physical and neurobehavioral development of male offspring. In puberty and early adult age the general activity and anxiety behaviors were also assessed in these rats. Results. With regard to maternal behavior, prenatal morphine did not modify the retrieval of pups without changing nest building. Dams challenged with morphine showed increased time to retrieval pups without interference of prenatal treatment. No differences were observed between offspring development of all groups. Prenatal and/or the challenge dose of morphine treatment increased the offspring locomotor and rearing behavior observed in an open field at 45 and 60 days of age. Only at 45 days of age it was observed a decreased immobility duration. In the elevated plus maze the prenatal or postnatal morphine treatment increased the number of entries but not in prenatal + postnatal morphine treated pups. Conclusion. Prenatal early morphine did not disrupt maternal behavior while postnatal morphine decreased it. In puberty and adult age, both prenatal and postnatal morphine increased the motor function of pup rats.
\end{abstract}

Keywords: Morphine treatment. Maternal behavior. Neurobehavioral development. Offspring 


\section{Highlights}

prenatal morphine treatment in early pregnancy did not modifies rat maternal behavior a challenge dose of morphine in dams early treated or not with morphine disrupt maternal behavior> these treatments did not alter physical or neurobehavioral parameters in male offspring morphine treatment in early pregnancy increase the motor anxiety of male offspring independently of the prenatal treatment in puberty and early adult age. 


\section{Introduction}

Opioid receptors play an important role in mother-pup interactions (Bridges and Grimm, 1982; Felicio et al., 1991). Recent studies suggested the involvement of these receptors in the physiological selection of behavior during lactation (Teodorov et al., 2006; Sukikara et al., 2007; Teodorov et al., 2008).

The endogenous opioid system comprises a group of endogenous ligands and peptide receptors that are widely distributed throughout the central nervous system, peripheral tissues, and the immune, cardiovascular, endocrine, and digestive systems (Waldhoer et al., 2004; Bodnar, 2011). At least 12 endogenous opioidergic ligands and three main opioid receptors $\mu$, $\kappa$, and $\delta$, have been identified (Gutstein and Akil, 2005). These receptors are expressed on the cell membrane and convert messages from extracellular to intracellular signals.

Pharmacological manipulations in mothers may, in addition to changing maternal behavior, produce physical or neurobehavioral effects in the offspring during childhood that may endure through puberty and into adulthood (Panksepp et al., 1994; Bernardi et al., 2011; Kirsten et al., 2011; Bernardi et al., 2012). Any impairment in these parameters may occur as a result of a direct action of drugs on the pups' brains or changes in the maternal environment. It is noteworthy that exposure to opiates during fetal development results in permanent changes in adults related to morphological, behavioral and biochemical measures. In this respect, prenatal morphine treatment from GD8 till birth associated to emotional stress have been shown to increase sensitivity to reward-related behaviors of rats in adult age (BuismanPijlman et al., 2009). Also, interactions of some endogenous opioids with opioid receptors during development are determinants of certain aspects of pain sensitivity as well as the density of particular opioid receptors in the postnatal period (Zagon et al., 1998). In both studies, the morphine treatment was performed during all or most of the pregnancy. However, still unknown is whether these effects endure throughout the animal's life or whether the phenomenon of synaptic plasticity can sufficiently reverse these effects when morphine was administered early in pregnancy. Moreover, the maternal-pups interactions were not investigated when mothers received morphine early in pregnancy.

Thus, the aims of the present study was to evaluate whether morphine treatment in mothers during early pregnancy (days 2-7 of pregnancy) alters maternal behavior and modifies physical and neurobehavioral development patterns in male offspring as well as motor activity assessed in puberty and early adult age. 


\section{Material and Methods}

Animals

The University Animal Care Committee approved all aspects of the research reported herein (protocol number 183/11). Adult male and female Wistar rats (School of Veterinary Medicine, University of São Paulo, São Paulo, Brazil), weighing approximately 300 and 250 $\mathrm{g}$, respectively, and 100 days of age, were used.

The animals were housed in a temperature- $\left(22 \pm 2^{\circ} \mathrm{C}\right)$ and humidity- $(48-60 \%)$ controlled environment on a $12 \mathrm{~h} / 12 \mathrm{~h}$ light/dark cycle with food and water available ad libitum throughout the study. Nulliparous female rats, determined to be in estrus by vaginal cytology, were randomly divided into pairs and placed overnight with one male rat previously determined to be fertile. Mating was confirmed by the presence of spermatozoa in vaginal smears on the following morning, which was designated gestational day 1 (GD1). Pregnant females were weighed and housed individually in plastic cages ( $40 \times 50 \times 20 \mathrm{~cm})$.

Forty dams were assigned to one of four groups with 10 animals each: SS group, which received six subcutaneous (s.c.) injections of $0.9 \%$ saline solution and challenged on day 5 of lactation with one injection of saline; SM group, which received six s.c. injections of saline and challenged with one injection of morphine $(3.5 \mathrm{mg} / \mathrm{kg}) ; \mathrm{MS}$ group, which received six s.c. injections of morphine and challenged with one injection of saline; MM group, which received six morphine injections and challenged with one injection of morphine. All of the experimental procedures are summarized in Fig. 1.

\section{Procedure}

Maternal studies

On day 5 of lactation, the pups were removed at 7:00 AM and placed in another home cage that was distant from their mother. Thirty minutes after removing the pups, the dams were acutely challenged with morphine $(3.5 \mathrm{mg} / \mathrm{kg}$, s.c.; Sigma Aldrich, St. Louis, MO, USA) or saline. Thirty minutes after the injections were administered to the dams, all eight pups were returned to their mothers, and maternal behavior testing began. The latencies (in seconds) to pup retrieval, grouping, crouching, and full maternal behavior (CMT) were scored. Animals were scored as displaying full maternal behavior if they retrieved all eight pups to the nest and displayed nursing behavior with their back arched over the pups for 3 consecutive minutes. If the animals did not fully express maternal behavior after $30 \mathrm{~min}$ of continuous observation, then they were checked every $15 \mathrm{~min}$ up to $60 \mathrm{~min}$ and then hourly 
until full maternal behavior was observed. Events observed after the first $30 \mathrm{~min}$ of continuous observation were recorded at the time of the first observation (e.g., if CMT was first observed at $60 \mathrm{~min}$, then the latency to full maternal behavior was scored as $60 \mathrm{~min}$ or $3600 \mathrm{~s}$ ). The same criterion was used for all of the other responses. For the behavioral tests, the observers were blind to the treatment of the animals.

\section{Offspring studies}

All of the pregnant rats (10/group) were allowed to give birth and nurture their offspring normally. No cross-fostering procedure was used. On the day of parturition (postnatal day 1 [PND1]), all of the litters were examined externally and sexed. The litters were organized into groups of eight pups each (four males and four females), and the remaining pups were culled. The anogenital distance (in millimeters) was determined at birth (PND1). The anogenital distance was considered the length from the anal opening to the genitals. The litter was considered the unit of analysis. One male pup from each litter (10 males) was marked daily with a colored felt-tip pen. The same male was used for body weight measurements, observations of testes descent (when the scrotum touched the testis) that began on PND16, and other physical and neurobehavioral development parameters.

Physical development. Each day, beginning on PND1, one male from each litter was observed for the following physical parameters: body weight (g), fur appearance, pinna detachment, hair growth, incisor eruption, auditory channel opening, eye opening, and testes descent. The day of appearance of these features was recorded, and litter means were calculated. The time of observation was always in the morning, between 8:00 AM and 12:00 PM.

Reflex development. The following reflex tests were conducted: surface righting reflex (i.e., the time spent to move to a normal ventral position after being placed on the back, beginning on PND5), palmar grasp reflex (i.e., closing the palm of the front paw when touched, beginning on PND2), negative geotaxis (i.e., the time to turn at least $90^{\circ}$ after being placed face down on a platform inclined $45^{\circ}$ for $60 \mathrm{~s}$, beginning on PND5), and adult walking (beginning on PND15).

General activity. The general activity of male and female pups was assessed in an open field apparatus based on the procedure described by Faggin and Palermo-Neto(1985) on PND21, PND45, and PND60 over a 3-min period. The apparatus was a round, $40 \mathrm{~cm}$ diameter (to pups in PND21) or $96 \mathrm{~cm}$ (to pups in PND 45 and PND60) wooden arena painted white, with 
the floor divided into 25 parts. Hand-operated counters and stopwatches were used to score the number of square crossed in central and peripheral area (i.e., the number of floor units entered with all four paws), rearing frequency (i.e., the number of times the animal stood on its hindlimbs), grooming behavior (number of face-washing) and immobility duration (i.e., the total number of seconds without movement). To minimize the potential effects of circadian changes on open field behavior, the testing of the animals from the four groups was alternated. The open field apparatus was washed with a 5\% ethanol/water solution between test sessions to avoid possible bias caused by odor clues left by previous subjects. All of the tests were conducted from 8:00 AM to 12:00 PM.

Elevated plus maze. Behavior in the elevated plus maze in male offspring was measured on PND60 after the open field test using the same animals. Thus, the animals were removed from the open field and immediately placed in the center of the elevated plus maze and observed for $5 \mathrm{~min}$. The device consisted of two opposite open arms $(50 \mathrm{~cm}$ length $\mathrm{x} 10 \mathrm{~cm}$ width) and two opposite closed arms (50 cm length $\times 10 \mathrm{~cm}$ width $\mathrm{x} 40 \mathrm{~cm}$ height) arranged perpendicularly. The floor of the maze was made of wood, painted gray, and located $50 \mathrm{~cm}$ above the floor. The center of the maze was open, and the walls of the closed arms began 2 $\mathrm{cm}$ from the center of the maze. Each animal was individually placed in the center of the maze with its head facing one of the open arms, and the following parameters were measured over a 5 min period: time spent in the open and closed arms, time in the center, and number of entries between the arms. The percentage of entries in closed arms was calculated by the ratio between the number of entries in the closed arms /total number of entries. The percentage of time in closed arms was calculated by the ratio of the time in closed arms/total time in both arms. Hand-operated counters and stopwatches were used to score these behaviors. To minimize the possible influence of circadian changes on behavior in the elevated plus maze, the groups were alternated. The device was washed with a $5 \%$ alcohol/water solution before placing the animals on it to avoid possible bias caused by odor clues left by previous rats.

Statistics

The litter was the experimental unit, and one male from each litter was used for each experiment. The results are expressed as mean \pm SEM. Homoscedasticity was verified using an F-test or Bartlett's test. Normality was verified using the Kolmogorov-Smirnov test. For all data, a two-way analysis of variance (ANOVA) was used, followed by Tukey's or Bonferroni multiple comparison tests. In all cases, the results were considered significant at $p<0.05$. 


\section{Results}

Maternal behavior

The prenatal treatment with morphine did not altered the pups retrieval (1rst pup- $\mathrm{F}_{1 / 36}$ $=0.25, \mathrm{p}=0.12,2^{\text {nd }}$ pup- $\mathrm{F}_{1 / 36}=0.88, \mathrm{p}=0.35,3^{\text {rd }}$ pup- $\mathrm{F}_{1 / 36}=1.60, \mathrm{p}=0.21$, all pups $-\mathrm{F}_{1 / 36}=$ $0.44, \mathrm{p}=0.51)$ but the postnatal treatment increased the time to retrieve pups (1rst pup- $\mathrm{F}_{1 / 36}=$ $6.60, p=0.01,2^{\text {nd }}$ pup- $F_{1 / 36}=8.58, p=0.006,3^{\text {rd }}$ pup- $F_{1 / 36}=4.94, p=0.03$, all pups $-F_{1 / 36}=$ $4.06, \mathrm{p}=0.05$ ), without interaction between factors ( $1 \mathrm{rst}$ pup- $\mathrm{F}_{1 / 36}=0.25, \mathrm{p}=0.61,2^{\mathrm{nd}}$ pup$\mathrm{F}_{1 / 36}=0.88, \mathrm{p}=0.35,3^{\text {rd }}$ pup- $\mathrm{F}_{1 / 36}=0.19, \mathrm{p}=0.66$, all pups $-\mathrm{F}_{1 / 36}=0.72, \mathrm{p}=0.40$ ). Fig. 2 shows these results. Relative to grouping, crouching and CMT no significant differences were found between groups after prenatal or postnatal treatment (Fig.1 -supplementary data).

Offspring

The results showed an increase in body weight in male offspring in the SM group only on PND45 $\left(\mathrm{F}_{3 / 36}=3.83, \mathrm{p}=0.01\right)$. The other parameters related to body weight and body weight gain were not altered (Table 1). No differences between groups were found in anogenital distance (SS group=4.7 \pm 0.12 , SM group- 4.6 \pm 0.09 , MS group- $4.4 \pm 0.09$ and MM group- $4.5 \pm 0.09, \mathrm{~F} 3 / 39=1.72 . \mathrm{p}=0.18$ ) or physical or neurobehavioral development (Table 1-supplementary data).

In the open field, total locomotion (Fig. 3 A), the treatment $\left(F_{2 / 72}=74.62, p<0.0001\right)$ and days of observation $\left(\mathrm{F} 1_{/ 72}=147.65, \mathrm{p}<0.0001\right)$ affected the results with interaction between factors $\left(\mathrm{F}_{3 / 72}=17.23, \mathrm{p}<0.0001\right)$. Relative to SS group, the Tuckey's test indicates an increased total locomotion in SM, MS and MM groups on 45 and 60 days of life.

In the open field, central locomotion (Fig. $3 \mathrm{~B}$ ), the treatment $\left(\mathrm{F}_{2 / 72}=40.79, \mathrm{p}<\right.$ $0.0001)$ but not the days of observation $\left(\mathrm{F}_{1 / 72}=2.87, \mathrm{p}<0.09\right)$ affected the results with interaction between factors $\left(\mathrm{F}_{3 / 72}=2.86, \mathrm{p}=0.04\right)$. Relative to SS group, the Tuckey's test indicates an increased central locomotion in SM, MS and MM groups on 45 days of life. Also, it was observed in 60 day a increased in central locomotion of MM group in relation to SS group. In addition the parameter was increased in MM group relative to MS group at the 60 days of life.

In relation to locomotion in the peripheral area (Fig.3C), the treatment $\left(\mathrm{F}_{2 / 72}=71.59\right.$, $\mathrm{p}<0.0001)$ and days of observation $\left(\mathrm{F}_{1 / 72}=230.14, \mathrm{p}<0.0001\right)$ affected the results with interaction between factors $\left(\mathrm{F}_{3 / 72}=23.52, \mathrm{p}<0.0001\right)$. Relative to SS group, the Tuckey's test indicates an increased central locomotion in SM, MS and MM groups on 45 and 60 days of 
life. In addition, a decreased locomotion in periphery was also observed in MS group relative to SM and MM groups in days 45 and 60 of life. No differences were observed between MS and MM groups.

In relation to rearing frequency (Fig.3D), the treatment $\left(F_{2 / 72}=7.32, p=0.002\right)$ affected the results but not the days of observation $\left(\mathrm{F}_{1 / 72}=2.01, \mathrm{p}=0.16\right)$ with interaction between factors $\left(\mathrm{F}_{3 / 72}=3.12, \mathrm{p}=0.03\right)$. Relative to SS group, the Tuckey's test indicates an increased rearing frequency in SM, MS and MM groups in 45 days of age. In addition, the parameter was increased in the SM group relative to SS group in the 60 days of age.

The grooming frequency (fig.3E) was affected by the treatment $\left(\mathrm{F}_{2 / 72}=4.82, \mathrm{p}=0.004\right)$ and by the days of observation $\left(\mathrm{F}_{1 / 72}=18.01, \mathrm{p}=0.0004\right)$; no interaction was observed between factors $\left(\mathrm{F}_{3 / 73}=0.82, \mathrm{p}=0.49\right)$. Relative to SS group, the Tuckey's test indicates an increased frequency of grooming of SM and MM groups at 45 days of age. In addition, the SM group presented a decreased in grooming behavior relative to MD group.

The immobility duration (Fig.3F), the treatment $\left(\mathrm{F}_{2 / 72}=2.97, \mathrm{p}=0.04\right)$ but not the days of observation $\left(\mathrm{F}_{1 / 72}=0.21, \mathrm{p}=0.66\right)$ affected the results with interaction between factors $\left(\mathrm{F}_{3 / 72}=3.84, \mathrm{p}<0.01\right)$. Relative to SS group, the Tuckey's test indicates decreased immobility locomotion in MS and MM groups on 45 days of age.

In the LCE, the total number of entries (Fig. $4 \mathrm{~A})$, the treatment $\left(\mathrm{F}_{2 / 72}=2.80, \mathrm{p}=0.05\right)$ and the days of observation did $\left(\mathrm{F}_{1 / 72}=46.25, \mathrm{p}<0.0001\right)$ affected the results without interaction between factors $\left(\mathrm{F}_{3 / 72}=1.80, \mathrm{p}=0.15\right)$. The Tuckey's test show a increased in the total number of entries IN MS group relative to SS and SM groups. The remained parameters did not show significant differences ( $\%$ of time-treatment- $F_{3 / 73}=0.47, p=0.71$, days$\mathrm{F}_{1 / 72}=3.76, \mathrm{p}=0.06$, interaction $-\mathrm{F}_{3 / 72}=0.73, \mathrm{p}=0.54$, Fig. $4 \mathrm{~B} ; \%$ of entries- treatment$\mathrm{F}_{3 / 73}=0.98, \mathrm{p}=0.41$, days $-\mathrm{F}_{1 / 72}=0, \mathrm{p}=1$, interaction $-\mathrm{F}_{3 / 72}=0, \mathrm{p}=1$, Fig. $4 \mathrm{C}$; time in the centertreatment- $F_{3 / 73}=0.16, p=0.92$, days $-F_{1 / 72}=2.60, p=0.11$, interaction $-F_{3 / 72}=0.32, p=0.81$, Fig.4D).

\section{Discussion}

Numerous studies have shown that early life experiences influence the development of pups. Various features originally described as hereditary may manifest during early postnatal development (Frankova, 1985). Thus, any experimental treatment can cause maternal postnatal effects that are directly or indirectly mediated by milk through maternal neglect in the care of the pups. Changes in the behavior of the mother can also produce changes in the physical development of the offspring(Smart and Dobbing, 1971). 
Opioid systems are plastic, adaptive, and functionally modulated by reproductive experience (Felicio et al., 1996). Opioids are well known to disrupt maternal behavior. Both morphine and $\beta$-endorphin, the latter of which is an endogenous opioid, have inhibitory effects on the maintenance of maternal behavior (Miranda-Paiva and Felicio, 1999; Slamberova et al., 2001).

The present study reveals that prenatal morphine treatment did not modifies the dam's maternal behavior. However, the challenged dose of morphine either in prenatal saline or morphine treatment impaired the ongoing maternal behavior. In fact, this drug decreased the interactions between the dams and their pups, reflected by longer latencies in retrieving the pups in SM and MM groups. The retrieving behavior may be more indicative of maternal motivation, whereas the nursing behavior may be indicative of a more reflexive maternal response (Stern, 1966). In other words, retrieving may represent an active voluntary response, which reflects interest in and an attraction toward pup-related stimuli and nursing may be transiently activated as a reflex when the female wanders near pups and they crawl under her (Stern, 1990; Stern and Protomastro, 2000; Pedersen et al., 2006). Thus, morphine injection on LD5 was responsible by the decreased motivation of dams while the prenatal treatment did not influence.

In this respect, opioids can interact with certain hormones that are responsible for the maintenance and promotion of childbirth and lactation. The secretion of oxytocin, a hormone that is important in the stimulation of childbirth and postpartum in the transfer of milk secretion, in the neurohypophysis, is inhibited by morphine (Haldar and Sawyer, 1978; Haldar et al., 1982; Bicknell et al., 1988; Tancin et al., 2000). Morphine also stimulates the secretion of the stress hormones prolactin and corticosterone, which can alter reproductive and maternal behaviors (Rosenblatt et al., 1988; Sukikara et al., 2011). Morphine-induced inhibition of oxytocin can alter maternal behavior with regard to breastfeeding (Cruz Ade et al., 2010). Thus, despite, morphine challenge reduced the maternal motivation, the grouping, crouching and CMT parameters of maternal behavior were not modified either by prenatal or postnatal morphine treatment. Thus, the maintenance of pups temperature and nursing were not disrupted by the morphine treatments.

The perinatal environment and maternal care can have long-lasting effects on behavior and physiology. Disturbances in maternal metabolism that alter nutrient supply from the mother to the fetus can induce structural and functional adaptations during fetal development, with lasting consequences for the growth and metabolism of the offspring throughout life 
(Aerts and Van Assche, 2006). During ontogeny, the central nervous system undergoes rapid cell proliferation, differentiation, and growth and is especially sensitive to changes induced by the environment. The physical development of the rat brain can be considerably affected by malnutrition during the suckling period. During lactation, malnourished mice have a reduced cellular cholesterol concentration and smaller brain volume. Therefore, conditions of nutritional deprivation can interfere with neurological development, reflected by the ontogeny of simple reflexes and behavioral patterns(Smart and Dobbing, 1971). The assessment of animal weight development is important in pharmacological studies because such changes are assumed to be an effect of the drug and not attributable to changes in the environment.

Previous studies have also shown that opiate-addicted mothers have opiate-withdrawn offspring (Zagon, 1985; Zagon and McLaughlin, 1992) and that exhibit neurobehavioral changes, such as hyperactivity and reduced mental and motor development (Zagon and McLaughlin, 1979; Zagon et al., 1979). Vestibular and proprioceptive exteroceptors are involved in the control of postural adjustment and gravitational signals, reflected by the righting reflex, adult walking, and negative geotaxis (Altman, 1975; Altman and Sudarshan, 1975). These parameters were also evaluated in the present study, and no significant differences were found. In the present study, no changes in these parameters were observed, indicating that gestational morphine treatment did not interfere with neurobehavioral development. Thus, early prenatal morphine challenged or not with morphine induced few deleterious effects on pup's development.

Many drugs administered by mothers have the ability to impair or improve motor patterns, and these changes can be observed in the offspring during infancy, adolescence, and adulthood. Thus to determine the endurance of the effects of maternal morphine treatment, general activity in the offspring was assessed in the open field on, PND45, and PND60. Alterations were found in general activity in the open field, which can evaluate neurobehavioral changes caused by both physiological and toxicological manipulations (Bernardi and Neto, 1979; Baso et al., 2003; Bevilacqua et al., 2011).

The interaction between mothers and offspring in different environments during lactation can increase locomotion in the central area of the open field in pups(Campos et al., 2013). This could reflect increased emotionality, if the central locomotion decreased and the peripheral locomotion increased. However, in this study, it was observed that, both peripheral and central locomotion were increased after prenatal and/or postnatal treatments, resulting in higher total locomotion. Thus, we suggest that early prenatal morphine or postnatal morphine 
increased the locomotor activity. These effects were observed at 45 days of age. In early adult age the increased in total locomotion was observed only in pup rats exposed prenatally to morphine (MS and MM groups) suggesting that this effect was longer lasting than non-treated prenatally with morphine .

Another interesting factor is that the increase in locomotor activity induced by drugs may indicate the drug's potential for abuse. Psychomotor activity reflects the reinforcing effect of drugs of abuse that results from stimulation of the mesocorticolimbic dopamine system (Steketee and Kalivas, 2011; Leyton and Vezina, 2013). The opioid system is known to be necessary for the maintenance of basal dopamine release (Bodnar, 2013). In the ventral tegmental area, mesolimbic A10-type dopaminergic neurons are stimulated by a tonically active system via disinhibition of interneurons that contain the inhibitory neurotransmitter GABA. Moreover, in the nucleus accumbens, dopamine release by A10 fibers is suppressed by a tonically inhibitory system. Therefore, opioid agonist drugs appear to exert their locomotor-stimulating effects through the release of dopamine in the nucleus accumbens.

According Bodnar (2013) may exert their effects by stimulating neuronal dopaminergic neurons in the ventral tegmental area and increase the release of dopamine in the nucleus accumbens in the mesocortical pathway. According to this author, this effect is attributable to the indirect action of opioids, modifying the activity of GABAergic interneurons that interact with neurons in the ventral tegmental area. Opioid-mediated inhibition of the release of the neurotransmitter GABA in the synaptic cleft results in the increased activity of dopaminergic neurons(Shim et al., 2013).

Based on the locomotor activity results, maternal morphine administration during early pregnancy may by hypothesized to influence the release of dopamine in the mesolimbic and mesocortical pathways and nigrostriatal system in offspring, thus increasing dopaminergic activity. This system may then be more sensitized and activated, which would explain the increase in locomotor activity, but future neurochemical studies are needed to confirm this hypothesis.

To verify if the increased general activity reflects also anxiety, we performed the study in the EPM. This model was initially proposed to evaluate the action of anxiolytic drugs in mice (Pellow et al., 1985; Pellow and File, 1986). It is based on the natural aversion of rodents to open and high places. Anxiogenic agents increase the activation of the HPA axis and anxiolytic agents favor the activation of the hypothalamic-pituitary-adrenal (HPA) axis, which modulates the action of corticotroph, corticosterone, and adrenocorticotropic hormones 
(Grinevich et al., 2012). Morphine administration in rats selectively increased the time spent on and number of entries into the open arms of the elevated plus maze, reflecting an anxiolytic effect of the drug (Hodgson et al., 2008; Motevasseli et al., 2010). However, perinatal exposure to morphine induced hypoactivity of the stress axis to strong stimulation at different postnatal ages (Klausz et al., 2011). The present study did not found increases in the $\%$ time spent or in the number of entries into the closed arms. Only an increased in the total entries in MS groups relative to SS group at 60 days of age, reflecting an increased motor activity. Because in the prenatal treatment with saline and postnatal treatment with morphine (Group SM) did not induced anxiety, we suggest that our treatments were unable to induces anxiety in pup rats.

\section{Conclusions}

Altogether, the present study demonstrated that prenatal morphine treatment during early gestation was unable to alter the maternal behavior. Only postnatal morphine exposure decreased the maternal motivation to retrieve pups. Both, prenatal and postnatal morphine treatments induced increases the locomotion behavior, which was more lasting in the groups treated with morphine prenatally. No anxiety was observed in all groups.

Acknowledgment

Research supported by FAPESP grants to E. Teodorov (2011/06392-0) and J.R.A Hernandes (2012/11845-6)

\section{References}

Addy M, Mitra AK, Ghosh KK, Hati AK (1983) Host preference of Phlebotomus argentipes in different biotopes. Trop Geogr Med 35:343-345.

Aerts L, Van Assche FA (2006) Animal evidence for the transgenerational development of diabetes mellitus. Int J Biochem Cell Biol 38:894-903.

Altman J (1975) Postnatal development of the cerebellar cortex in the rat. IV. Spatial organization of bipolar cells, parallel fibers and glial palisades. J Comp Neurol 163:427-447.

Altman J, Sudarshan K (1975) Postnatal development of locomotion in the laboratory rat. Anim Behav 23:896-920.

Baso AC, Goulart FC, Teodorov E, Felicio LF, Bernardi MM (2003) Effects of maternal exposure to picrotoxin during lactation on physical and reflex development, square crossing and sexual behavior of rat offspring. Pharmacol Biochem Behav 75:733-740.

Bernardi MM, Neto JP (1979) Effects of abrupt and gradual withdrawal from long-term haloperidol treatment on open field behavior of rats. Psychopharmacology (Berl) 65:247-250.

Bernardi MM, Kirsten TB, Spinosa HS, Manzano H (2011) Ivermectin impairs sexual behavior in sexually naive, but not sexually experienced male rats. Res Vet Sci 91:77-81. 
Bernardi MM, Kirsten TB, Teodorov E, Baso AC, Prosdocimi FC, Felicio LF (2012) Maternal exposure to picrotoxin modifies the response of the GABAA receptor during sexual behavior of adult male rat offspring. Behav Pharmacol 23:703-709.

Bevilacqua AH, Suffredini IB, Romoff P, Lago JH, Bernardi MM (2011) Toxicity of apolar and polar Lantana camara L. crude extracts in mice. Res Vet Sci 90:106-115.

Bicknell RJ, Leng G, Lincoln DW, Russell JA (1988) Naloxone excites oxytocin neurones in the supraoptic nucleus of lactating rats after chronic morphine treatment. J Physiol 396:297-317.

Bodnar RJ (2011) Endogenous opiates and behavior: 2010. Peptides 38:463-522.

Bodnar RJ (2013) Endogenous opiates and behavior: 2012. Peptides 50:55-95.

Bridges RS, Grimm CT (1982) Reversal of morphine disruption of maternal behavior by concurrent treatment with the opiate antagonist naloxone. Science 218:166-168.

Buisman-Pijlman FT, Gerrits MA, Van Ree JM (2009) Increased opioid release in specific brain areas in animals exposed to prenatal morphine and emotional stress later in life. Neuroscience 159:405-413.

Campos AC, Fogaca MV, Aguiar DC, Guimaraes FS (2013) Animal models of anxiety disorders and stress. Rev Bras Psiquiatr 35 Suppl 2:S101-111.

Cruz Ade M, Maiorka PC, Canteras NS, Sukikara MH, Felicio LF (2010) Morphine treatment during pregnancy modulates behavioral selection in lactating rats. Physiol Behav 101:40-44.

Faggin BM, Palermo-Neto J (1985) Differential alterations in brain sensitivity to amphetamine and pentylenetetrazol in socially deprived mice. Gen Pharmacol 16:299-302.

Felicio LF, Mann PE, Bridges RS (1991) Intracerebroventricular cholecystokinin infusions block betaendorphin-induced disruption of maternal behavior. Pharmacol Biochem Behav 39:201-204.

Felicio LF, Florio JC, Sider LH, Cruz-Casallas PE, Bridges RS (1996) Reproductive experience increases striatal and hypothalamic dopamine levels in pregnant rats. Brain Res Bull 40:253256.

Frankova S (1985) Behavioural responses of rats to early housing conditions and to protein-energy malnutrition. Act Nerv Super (Praha) 27:89-98.

Grinevich V, Seeburg PH, Schwarz MK, Jezova D (2012) Homer 1 - a new player linking the hypothalamic-pituitary-adrenal axis activity to depression and anxiety. Endocr Regul 46:153159.

Gutstein HB, Akil H (2005) Analgésicos opióides. In: Goodman \& Gilman: as bases farmacológicas da terapêutica, 10 Edition (Hardman JG, Limbird LE, eds), pp 427-464. Rio de Janeiro: McGraw-Hill

Haldar J, Sawyer WH (1978) Inhibition of oxytocin release by morphine and its analogs. Proc Soc Exp Biol Med 157:476-480.

Haldar J, Hoffman DL, Zimmerman EA (1982) Morphine, beta-endorphin and [D-Ala2] Metenkephalin inhibit oxytocin release by acetylcholine and suckling. Peptides 3:663-668.

Hodgson SR, Hofford RS, Norris CJ, Eitan S (2008) Increased elevated plus maze open-arm time in mice during naloxone-precipitated morphine withdrawal. Behav Pharmacol 19:805-811.

Kirsten TB, Chaves GP, Taricano M, Martins DO, Florio JC, Britto LR, Torrao AS, Palermo-Neto J, Bernardi MM (2011) Prenatal LPS exposure reduces olfactory perception in neonatal and adult rats. Physiol Behav 104:417-422.

Klausz B, Pinter O, Sobor M, Gyarmati Z, Furst Z, Timar J, Zelena D (2011) Changes in adaptability following perinatal morphine exposure in juvenile and adult rats. Eur J Pharmacol 654:166172.

Leyton M, Vezina P (2013) Striatal ups and downs: their roles in vulnerability to addictions in humans. Neurosci Biobehav Rev 37:1999-2014.

Miranda-Paiva CM, Felicio LF (1999) Differential role of cholecystokinin receptor subtypes in opioid modulation of ongoing maternal behavior. Pharmacol Biochem Behav 64:165-169.

Motevasseli T, Rezayof A, Zarrindast MR, Nayer-Nouri T (2010) Role of ventral hippocampal NMDA receptors in anxiolytic-like effect of morphine. Physiol Behav 101:608-613.

Panksepp J, Nelson E, Siviy S (1994) Brain opioids and mother-infant social motivation. Acta Paediatr Suppl 397:40-46. 
Pedersen CA, Vadlamudi SV, Boccia ML, Amico JA (2006) Maternal behavior deficits in nulliparous oxytocin knockout mice. Genes Brain Behav 5:274-281.

Pellow S, File SE (1986) Anxiolytic and anxiogenic drug effects on exploratory activity in an elevated plus-maze: a novel test of anxiety in the rat. Pharmacol Biochem Behav 24:525-529.

Pellow S, Chopin P, File SE, Briley M (1985) Validation of open:closed arm entries in an elevated plus-maze as a measure of anxiety in the rat. J Neurosci Methods 14:149-167.

Rosenblatt JS, Mayer AD, Giordano AL (1988) Hormonal basis during pregnancy for the onset of maternal behavior in the rat. Psychoneuroendocrinology 13:29-46.

Shim I, Stratford TR, Wirtshafter D (2013) Dopamine is differentially involved in the locomotor hyperactivity produced by manipulations of opioid, GABA and glutamate receptors in the median raphe nucleus. Behav Brain Res 261C:65-70.

Slamberova R, Szilagyi B, Vathy I (2001) Repeated morphine administration during pregnancy attenuates maternal behavior. Psychoneuroendocrinology 26:565-576.

Smart JL, Dobbing J (1971) Vulnerability of developing brain. II. Effects of early nutritional deprivation on reflex ontogeny and development of behaviour in the rat. Brain Res 28:85-95.

Steketee JD, Kalivas PW (2011) Drug wanting: behavioral sensitization and relapse to drug-seeking behavior. Pharmacol Rev 63:348-365.

Stern J (1966) Somatosensation and maternal care in Norway rats. In: Parental Care: Evolution,Mechanisms, and Adaptive Significance.Advances in the Study of Behavior. (JS R, CT S, eds). New York: Academic Press.

Stern JM (1990) Multisensory regulation of maternal behavior and masculine sexual behavior: a revised view. Neurosci Biobehav Rev 14:183-200.

Stern JM, Protomastro M (2000) Effects of low dosages of apomorphine on maternal responsiveness in lactating rats. Pharmacol Biochem Behav 66:353-359.

Sukikara MH, Platero MD, Canteras NS, Felicio LF (2007) Opiate regulation of behavioral selection during lactation. Pharmacol Biochem Behav 87:315-320.

Sukikara MH, Cruz AM, Felippe EC, Anselmo-Franci JA, Canteras NS, de Oliveira CA, Felicio LF (2011) Morphine-induced changes in opioid sensitivity in postpartum females: a unique progesterone response. J Neuroendocrinol 23:1134-1138.

Tancin V, Kraetzl WD, Schams D (2000) Effects of morphine and naloxone on the release oxytocin and on milk ejection in dairy cows. J Dairy Res 67:13-20.

Teodorov E, Modena CC, Sukikara MH, Felicio LF (2006) Preliminary study of the effects of morphine treatment on opioid receptor gene expression in brain structures of the female rat. Neuroscience 141:1225-1231.

Teodorov E, Tomita AT, Banon GP, Gil IG, Bernardi MM, Felicio LF (2008) Behavioral effects of acute stimulation of kappa-opioid receptors during lactation. Pharmacol Biochem Behav 90:534-539.

Waldhoer M, Bartlett SE, Whistler JL (2004) Opioid receptors. Annu Rev Biochem 73:953-990.

Yeung FI, Newman HN, Addy M (1983) Subgingival metronidazole in acrylic resin vs. chlorhexidine irrigation in the control of chronic periodontitis. J Periodontol 54:651-657.

Zagon IS (1985) Opioids and development: new lessons from old problems. NIDA Res Monogr 60:58-77.

Zagon IS, McLaughlin PJ (1979) Motor activity and learning ability in rats perinatally exposed to methadone. NIDA Res Monogr 27:121-127.

Zagon IS, McLaughlin PJ (1992) Maternal exposure to opioids and the developing nervous system:laboratory findings. . In: Maternal Substance Abuse and the Developing Nervous System. (In: Zagon IS, Slotkin TA, eds), pp 241-282. New York: Academic Press.

Zagon IS, McLaughlin PJ, Thompson CI (1979) Development of motor activity in young rats following perinatal methadone exposure. Pharmacol Biochem Behav 10:743-749.

Zagon IS, Tobias SW, Hytrek SD, McLaughlin PJ (1998) Opioid receptor blockade throughout prenatal life confers long-term insensitivity to morphine and alters mu opioid receptors. Pharmacol Biochem Behav 59:201-207. 
Table 1 - Body weight $(\mathrm{g})$ and body weight gain $(\mathrm{g})$ of male offspring from dams that received or not morphine in early gestation. Data are presented by mean \pm SEM ( $n=10 /$ itters/group).

\begin{tabular}{llll}
\hline $\begin{array}{l}\text { Groups } / \\
\text { Days }\end{array}$ & $\delta$ SS & $\delta^{1} \mathbf{M S}$ & $\delta^{1} \mathbf{M M}$ \\
\hline
\end{tabular}

\begin{tabular}{ccccc}
1 & $21.7 \pm 2.3$ & $20.7 \pm 1.1$ & $26.6 \pm 0.5^{*}$ & $23.5 \pm 1.3$ \\
7 & $59.7 \pm 6.3$ & $53.1 \pm 2.7$ & $61.6 \pm 3.2$ & $57.4 \pm 3.4$ \\
10 & $76.5 \pm 7.9$ & $65.5 \pm 3.8$ & $73.4 \pm 3.8$ & $73.3 \pm 4.6$ \\
14 & $95.8 \pm 9.9$ & $85.0 \pm 4.6$ & $91.5 \pm 4.2$ & $99.0 \pm 7.9$ \\
21 & $128.7 \pm 12.84$ & $129.8 \pm 7.8$ & $127.6 \pm 6.9$ & $149.5 \pm 14.3$ \\
45 & $442.6 \pm 43.6$ & $526.4 \pm 25.6^{*}$ & $436.7 \pm 23.3$ & $540.4 \pm 1.5$ \\
60 & $883.6 \pm 94.2$ & $847.5 \pm 33.2$ & $897.6 \pm 9.7$ & $978.0 \pm 25.6$ \\
\hline \multicolumn{5}{c}{ Body weight gain (g) } \\
$1-10$ & $49.8 \pm 6.0$ & $44.9 \pm 3.4$ & $46.8 \pm 3.5$ & $49.8 \pm 4.2$ \\
$10-21$ & $52.2 \pm 6.2$ & $64.2 \pm 5.4$ & $54.2 \pm 3.7$ & $76.2 \pm 10.5$
\end{tabular}

$p<0.05$ in relation do SS group. ANOVA followed by Bonferroni multiple comparison test. 


\section{Caption to figures}

Fig.1 Experimental design

Fig. 2- Latencies to retrieve pups (seconds) of maternal behavior observed in female rats on day 5 of lactation treated in early gestation with morphine. Data are expressed as mean \pm SEM. ${ }^{*} \mathrm{p}<0.05$ compared with all other groups $(\mathrm{n}=10 /$ litters $)$. ANOVA followed by Tukey test. .

Fig. 3- Effects of morphine treatment in early gestation on open-field behaviors of male rat pups observed at, 45 and 60 days of age. Data are expressed as mean \pm SEM. ${ }^{*} p<0.05$ compared with all other groups $(n=10 /$ litters $)$. ANOVA followed by Tukey test.

Fig. 4- Effects of morphine treatment in early gestation on elevated plus maze behaviors of male rat pups observed at 45 and 60 days of age. Data are expressed as mean \pm SEM. ${ }^{*} p<$ 0.05 compared with all other groups $(n=10 /$ litters). ANOVA followed by Tukey test.

\section{Caption to supplementary figure}

Grouping, couching and CMT of maternal behavior observed in female rats on day 5 of lactation treated in early gestation with morphine. Data are expressed as mean \pm SEM. $* \mathrm{p}<$ 0.05 compared with all other groups $(\mathrm{n}=10 /$ litters $)$. ANOVA followed by Tukey test. 
Fig.1

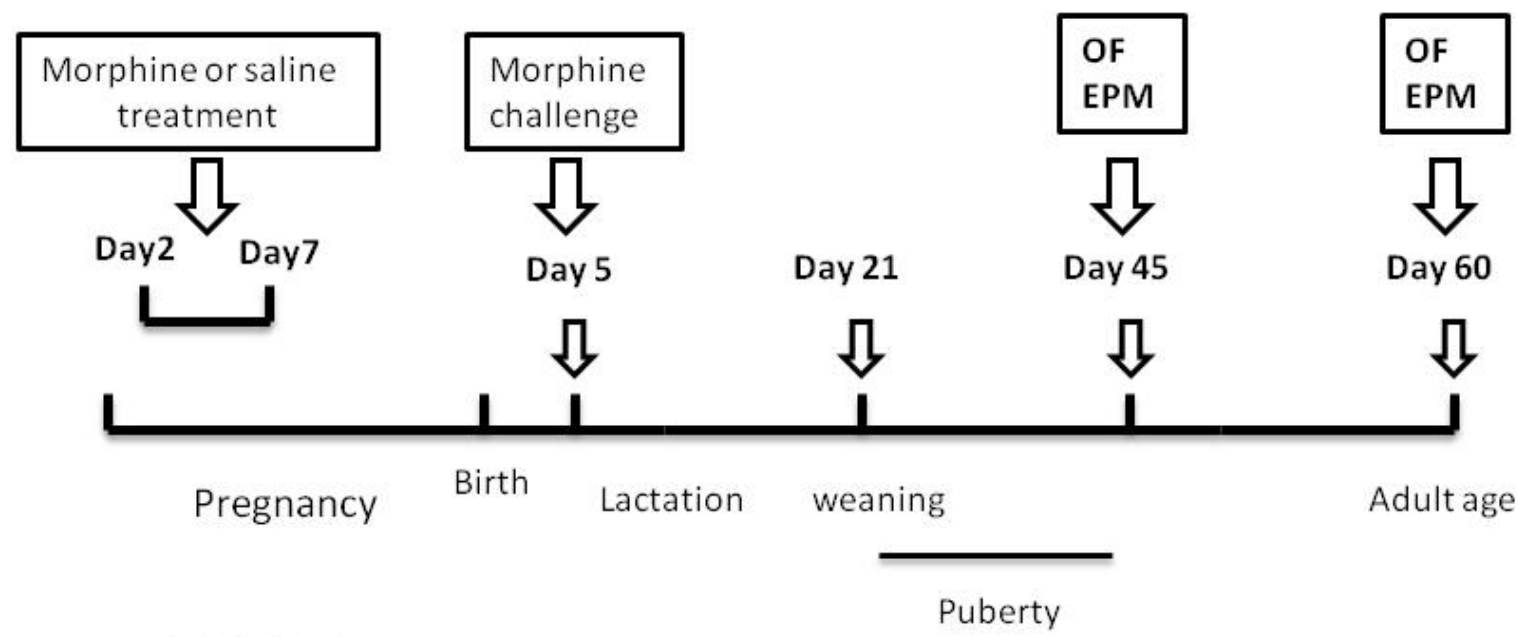

OF-Open field behavior EPM-Elevated plus maze 
Fig. 2
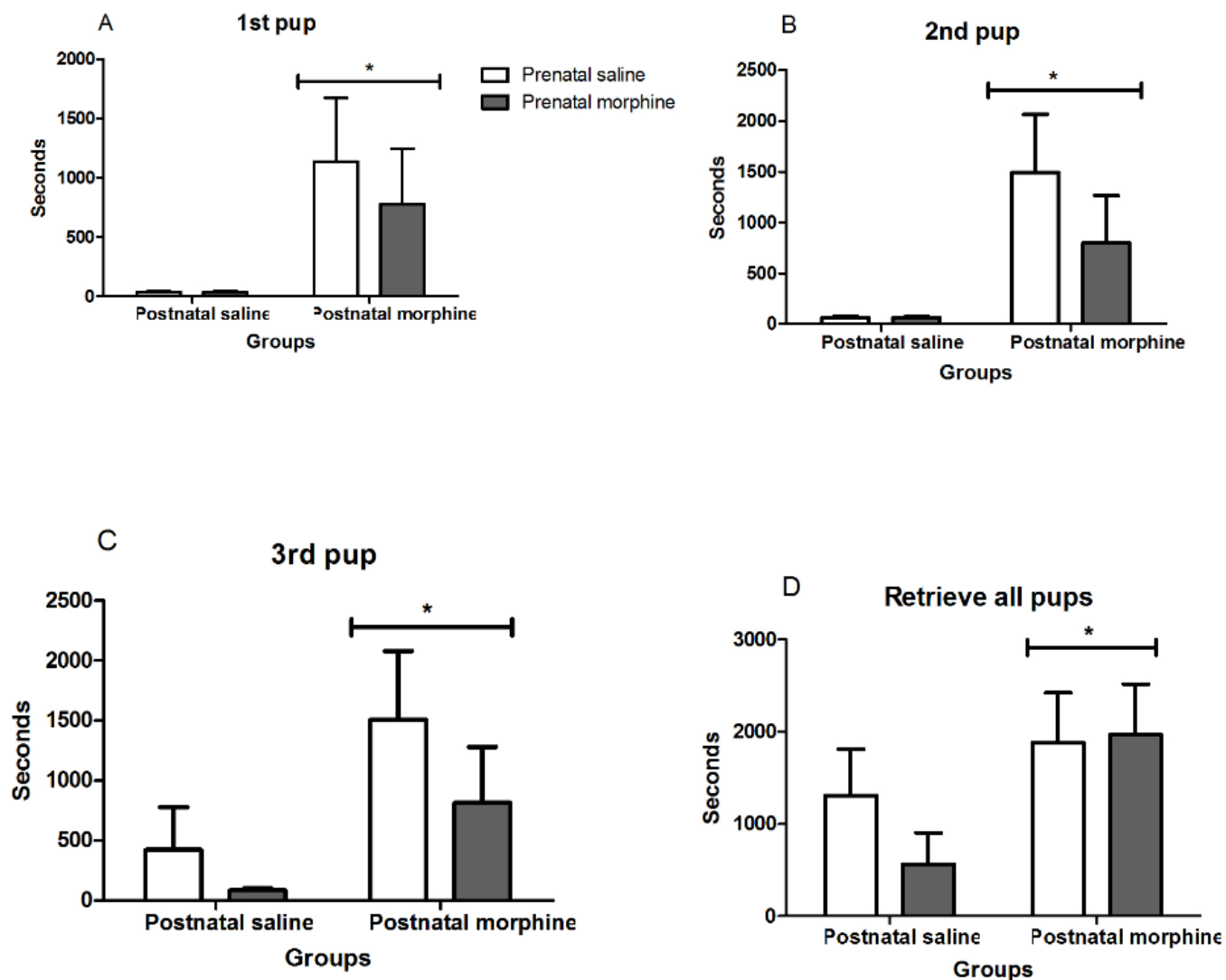
Fig. 3
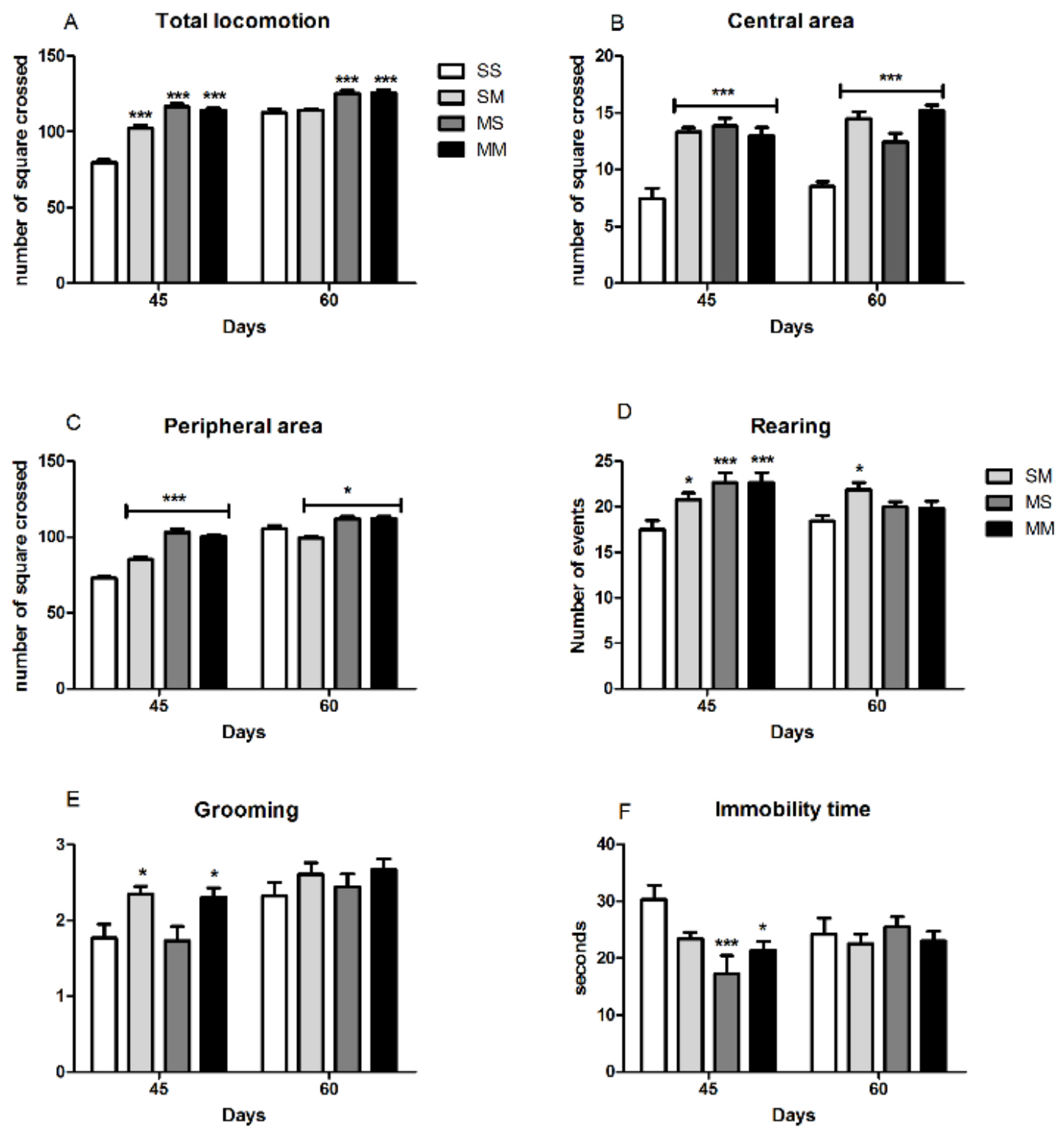
Fig.4
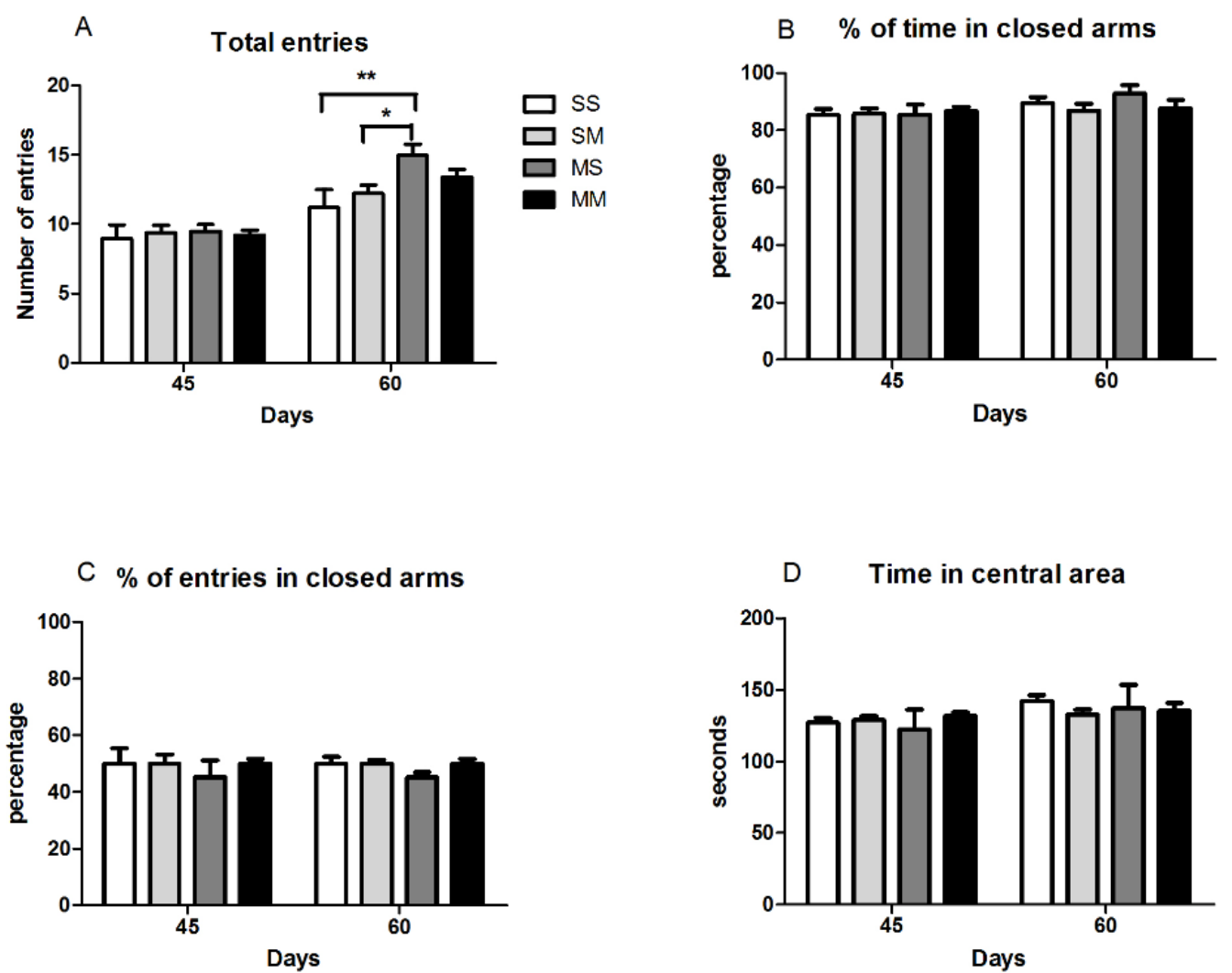
Supplementary figure
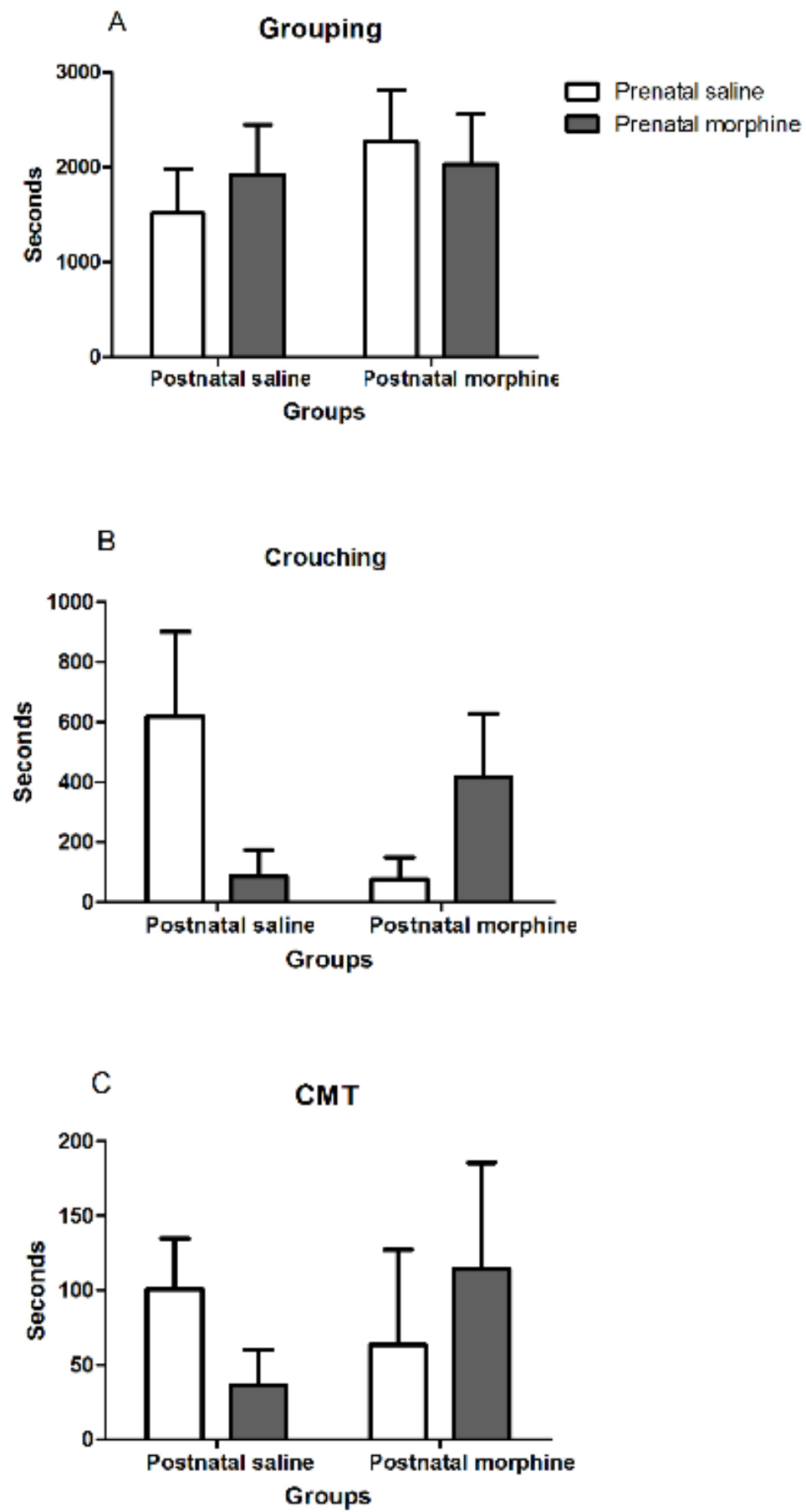